Andrews University

Digital Commons @ Andrews University

Dissertations

Graduate Research

2012

\title{
The Markan "Divorce" Pericope: an Exegesis
}

Carlos C. Camarena

Andrews University, ccarlos@andrews.edu

Follow this and additional works at: https://digitalcommons.andrews.edu/dissertations

Part of the Biblical Studies Commons

\section{Recommended Citation}

Camarena, Carlos C., "The Markan "Divorce" Pericope: an Exegesis" (2012). Dissertations. 1666.

https://digitalcommons.andrews.edu/dissertations/1666

https://dx.doi.org/10.32597/dissertations/1666

This Dissertation is brought to you for free and open access by the Graduate Research at Digital Commons @ Andrews University. It has been accepted for inclusion in Dissertations by an authorized administrator of Digital Commons@ Andrews University. For more information, please contact repository@andrews.edu. 


\section{ABSTRACT}

\section{THE MARKAN “DIVORCE” PERICOPE: AN EXEGESIS}

by

Carlos C. Camarena

Adviser: Robert M. Johnston 


\section{ABSTRACT OF GRADUATE STUDENT RESEARCH}

Dissertation

Andrews University

Seventh-day Adventist Theological Seminary

Title: THE MARKAN “DIVORCE” PERICOPE: AN EXEGESIS

Name of researcher: Carlos C. Camarena

Name and degree of faculty adviser: Robert M. Johnston, Ph.D.

Date completed: April 2012

Problem

Jesus pronounced one major saying on the question of "divorce" in the NT for which there are four independent reports: three in the Gospels (Matt 19:1-9, Mark 10:112, and Luke 16:18) and one in Paul (1 Cor 7:10-16). The major accounts (Markan and Matthean $)^{1}$ though appearing to be similar, there are significant grammatical and syntactical differences and two vastly different ethnic foci (a Matthean-Jewish focus versus a Markan-Gentile one) so as to each merit independent analysis. Traditionally, however, the Church has mostly relied on the Matthean account to derive its theology on divorce and remarriage, even when Mark's account is widely considered to precede the

${ }^{1}$ The Lukan account, though considered by many to be the most primitive, does not provide us with much context for it to warrant exegetical consideration. 
Matthean account. The tendency to conflate all divorce sayings in the Bible, and specifically in the NT, into one essential meaning creates insurmountable problems when such sayings are studied independently. Because no major study has specifically focused on the "divorce" logion as it appears in Mark, major questions related to Jesus" teaching on the subject still remain unanswered.

$$
\text { Purpose }
$$

The purpose of this dissertation is an attempt to make a contextual assessment of Jesus" teaching on "divorce" according to Mark in order to define its basic thrust within a Gentile community (in relation to Matthew's Jewish community) and to ellucidate a clearer picture of what the NT Jesus may have taught on the subject.

\section{Method}

This study is divided into six major chapters and an appendix. Chapter 1 gives a bird's-eye view into some of the modern scholarship regarding the "divorce" sayings in both Gospels. Chapter 2 focuses its attention on the locale of the Gentile audience of Mark, analyzing whether the purported Gentile-Roman audience could actually fit a Palestinian milieu. Chapter 3 considers the divorce practices among the Romans and analyzes whether those practices may have reached Palestinians via Roman influence. Chapter 4 considers a grammatical-syntactical structure and connectors that may identify the Markan pericope (Mark 10:1-12) as a unit. In this chapter I also analyze the crux word translated "to divorce" in the Gospels and show that Greek writers two centuries prior to the NT as well as a century after do not consistently use the term apolūo to mean to divorce, and neither do modern translators. In chapter 5 I conduct an exegesis in which I analyze Jesus' statement based on the Mosaic legislation (Deut 24:1-4) and the 
raditional Jewish interpretation of such legislation. I discuss unresolved issues in chapter 5 and present the plausible interpretation of the Markan "divorce" saying. The appendix contains a historical analysis on the use of the crux word translated "to divorce": apoluō and its derivatives.

\section{Conclusions}

The unity of the Markan pericope (Mark 10:1-12), the historical context in which Mark places Jesus" "divorce" saying, the traditional Jewish interpretation of Deut 24:1-4, and the generally known term used for divorce during NT times, all point to the probability that Jesus may have not been referring to the practice of divorce, but rather condemning the practice of desertion, specifically pointing to the house of Herod where Herodias left her husband and whose letter of divorce did not give her the right to divorce him, according to Jewish views, and an indirect attack to Herod's own expulsion of his Nabatean wife. If this study is to be of any value, it should point us to the importance of doing independent analysis of all texts/pericopes in which this subject may be found before making generalized statements or taking theological sides. 

Andrews University

Seventh-day Adventist Theological Seminary

THE MARKAN “DIVORCE” PERICOPE: AN EXEGESIS

\author{
A Dissertation \\ Presented in Partial Fulfillment \\ of the Requirements for the Degree \\ Doctor of Philosophy
}

by

Carlos C. Camarena

April 2012 
(C) Copyright by Carlos C. Camarena 2012 All Rights Reserved 
THE MARKAN “DIVORCE” PERICOPE: AN EXEGESIS

\author{
A dissertation \\ presented in partial fulfillment \\ of the requirements for the degree \\ Doctor of Philosophy
}

by

Carlos C. Camarena

APPROVAL BY THE COMMITTEE:

Faculty Adviser,

Robert M. Johnston

Professor of New Testament

Richard M. Davidson

Professor of Old Testament

W. Larry Richards

Professor of New Testament
Director of Ph.D./Th.D. Program

Thomas Shepherd

Dean, SDA Theological Seminary Denis Fortin 


\section{TABLE OF CONTENTS}

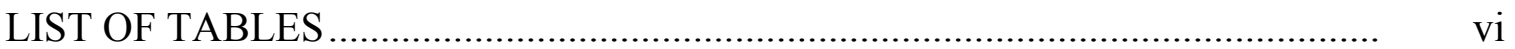

LIST OF ABBREVIATIONS ....................................................................... vii

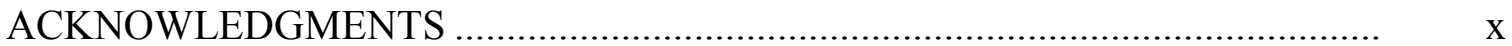

\section{Chapter}

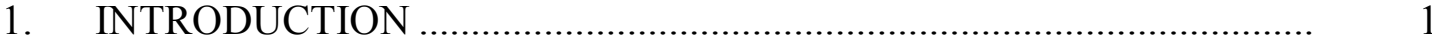

A Brief Modern History ..................................................................

Did He Say It? ....................................................................

Jesus and the Rabbis ................................................................... 10

No Divorce—No Remarriage ....................................................... 14

For the Kingdom's Sake ............................................................ 17

The Jesus Seminar....................................................................... 19

The Question of Grammar ............................................................ 20

Background to the Problem ............................................................... 21

Statement of the Problem................................................................... 29

Statement of Purpose .......................................................................... 29

Justification for the Study ............................................................. $\quad 30$

Assumptions................................................................................ 31

Scope and Delimitations ................................................................ 32

Methodology ......................................................................... 33

2. THE GALILEAN-GENTILE AUDIENCE OF MARK …............................ 36

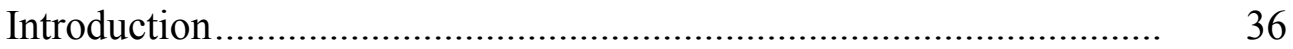

The Gentile-Roman Audience of Mark ............................................... 37

Mark's Other Non-Palestinian and Non-Roman Audience .................. $\quad 39$

Mark's Palestinian Audience ............................................................. 41

Hellenistic Influences in Galilee....................................................... 42

Mark's Use of Foreign Terms............................................................ 53

Summary and Conclusions ............................................................. 57

3. MARRIAGE AND DIVORCE UNDER THE ROMANS:

FIRST CENTURY BCE TO FIRST CE..................................................... 61

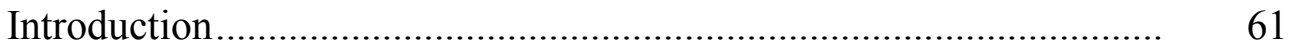

Marriage and Divorce Laws in Pre-Imperial Times ............................ 65 


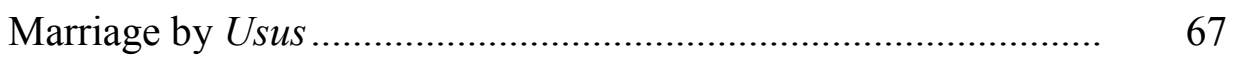

Marriage by Coemptio …………………………………............ 72

Marriage by Confaerratio ...........................................................

Women's Movement of the Late Republic .......................................... 77

Marriage and Divorce during Imperial Times .................................... 81

Free Marriage and Concubinage ..................................................... 82

Fictitious Marriages ……………………………………......... 86

The Age of Marriage................................................................... 87

The Decaying Status of Marriage Relationships ........................... 88

Long Absences of Husbands...................................................... 90

Unhappy Marriages.................................................................... 92

Summary and Conclusions ................................................................. 96

4. A TEXTUAL AND LEXICAL ANALYSIS OF MARK 10:1-12 ............. 99

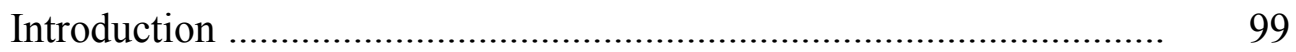

The Delimitation of the Pericope ............................................................ 100

A Structural Analysis........................................................................ 104

A Lexical and Syntactical Analysis of Mark 10:2-12......................... 107

'A

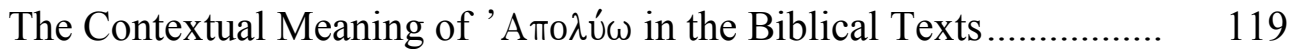

The Septuagint (LXX) ............................................................ 121

The New Testament ..................................................................... 128

Term(s) for Divorce in the First Century ............................................... 130

In Extra-Biblical Sources .......................................................... 130

In Biblical Sources ................................................................... 134

Summary and Conclusions .................................................................. 137

5. THE MARKAN “DIVORCE”: AN EXEGESIS ………………………….... 139

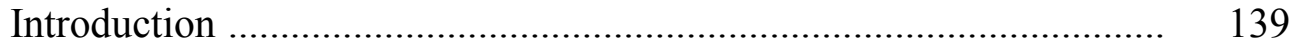

The Geography ............................................................................. 141

The Pharisees ....................................................................................... 144

The "Test" Question ............................................................................... 146

The Role of Moses ........................................................................... 159

The "Hardness of Heart" Motif ............................................................... 169

The House of Herod............................................................................. 174

"In the House" ........................................................................... 179

Summary and Conclusions .............................................................. 185

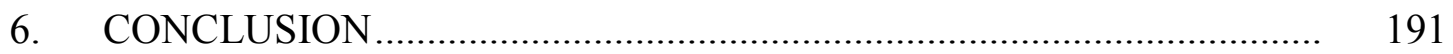

Concluding Remarks........................................................................... 203

Appendix: THE MEANING OF 'A

The First Century BCE ……………………………..................... 208 
The Pseudepigrapha ................................................................... 208

Dionysius of Halicarnassus: 60 BCE to 7 CE................................ 209

Diodorus of Sicily …………………….................................. 211

Late First Century BCE to Mid-First Century CE .............................. 213

Philo-Judeus of Alexandria........................................................ 213

Strabo the Geographer .............................................................. 214

Plutarch ......................................................................... 215

The First Century CE .................................................................... 218

Flavius Josephus ……......................................................... 219

Clement of Rome .................................................................. 224

Dio Chrysostom .................................................................... 225

Epictetus...................................................................... 225

The Second Century ........................................................................... 226

The Apostolic Fathers ………………………………............... 226

The Martyrdom of Polycarp................................................... 226

The Shepherd of Hermas ........................................................ $\quad 227$

The New Testament Apocrypha ……………………….......... 228

Appianus of Alexandria ........................................................ 229

Clement of Alexandria ......................................................... $\quad 230$

Cassius Dio ................................................................... 232

Marcus Aurelius Antonius ..................................................... 233

Occasional Citations in Other Second Century

CE Works................................................................. 234

Summary and Conclusions .............................................................. 235

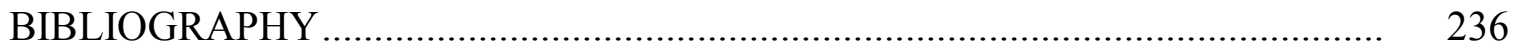

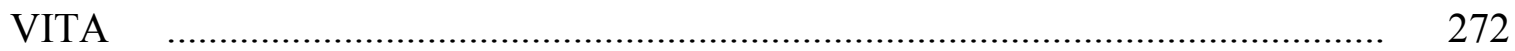




\section{LIST OF TABLES}

1. Markan - Matthean Comparison of the "Divorce" Logia ........................ 3

2. A comparison of translations for $\dot{\alpha} \pi 0 \lambda \hat{v} \sigma \alpha \iota$ in English Bibles on.......... 111 Matthew 19:3, Mark 10:2, and 10:4

3. A comparison of translations for $\dot{\alpha} \pi 0 \lambda \hat{v} \sigma \alpha \iota$ in Spanish Bibles on.......... 112 Matthew 19:3, Mark 10:2, and 10:4

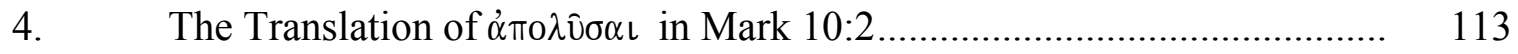

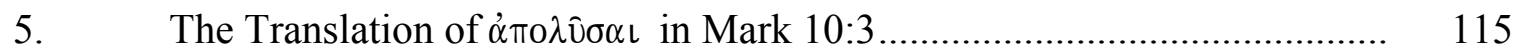

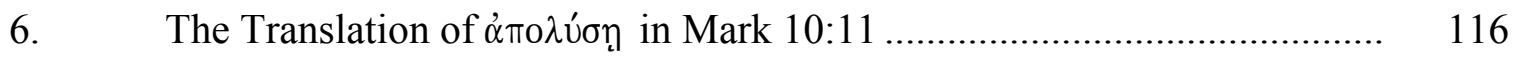

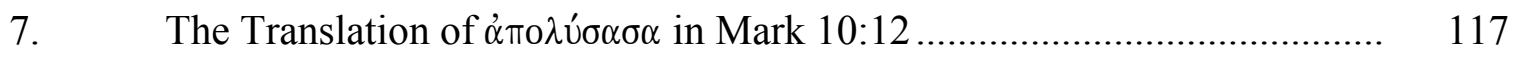

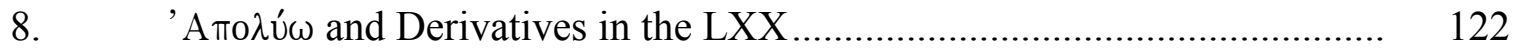




\section{LIST OF ABBREVIATIONS}

\begin{tabular}{|c|c|}
\hline ABRL & Anchor Bible Reference Library \\
\hline$A E R$ & American Ecclesiatical Review \\
\hline$A J T$ & Asia Journal of Theology \\
\hline AthR & Anglican Theological Review \\
\hline$b$. & Babylonian Talmud \\
\hline$B A R$ & Biblical Archaeology Review \\
\hline BDAG & $\begin{array}{l}\text { Bauer, W., F. W. Danker, W. F. Arndt, and F. W. Gingrich. Greek-English } \\
\text { Lexicon of the New Testament and Other Early Christian Literature. } 3 \mathrm{~d} \\
\text { ed. Chicago, } 2000\end{array}$ \\
\hline$B J R L$ & Bulletin of the John Rylands University Library of Manchester \\
\hline$C B Q$ & Catholic Biblical Quarterly \\
\hline $\mathrm{CD}$ & Cumram Documents \\
\hline CGTC & Cambridge Greek Testament Commentary \\
\hline$C T$ & Christianity Today \\
\hline$C T J$ & Calvin Theological Journal \\
\hline$C T M$ & Concordia Theological Monthly \\
\hline Did & Didaskalia \\
\hline $\mathrm{ICC}$ & International Critical Commentary \\
\hline Int & Interpretation \\
\hline$I T Q$ & Irish Theological Quarterly \\
\hline JATS & Journal of the Adventist Theological Society \\
\hline$J B L$ & Journal of Biblical Literature \\
\hline
\end{tabular}


JETS Journal of the Evangelical Theological Society

JJS Journal of Jewish Studies

JPS Jewish Publication Society

JSNT Journal for the Study of the New Testament

JTS Journal of Theological Studies

LCL Loeb Classical Library

m. Mishna

NCB New Century Bible

NEArch Near East Archaeology

NICNT New International Commentary on the New Testament

NovT Novum Testamentum

NTS New Testament Studies

OLD Oxford Latin Dictionary. Edited by P. G. W. Glare. Oxford, 1982

RevExp Review and Expositor

SBJT Southern Baptist Journal of Theology

SBL Society of Biblical Literature

SPCK Society for Promoting Christian Knowledge

TDNT Theological Dictionary of the New Testament. Edited by G. Kittel and G. Friedrich. Translated by G. W. Bromiley. 10 vols. Grand Rapids, 19641976

TJ Trinity Journal

TLG Thesaurus linguae graecae: Canon of Greek Authors and Works. Edited by L. Berkowitz and K. A. Squitier. 3d ed. Oxford, 1990

TS Theological Studies

TynBul Tyndale Bulletin 


\section{WLQ Wisconsin Lutheran Quarterly}

y. Jerusalem Talmud

ZNW Zeitschrift für die neutestamentliche Wissenschaft und die Kunde der älteren Kirche 


\section{ACKNOWLEDGMENTS}

To my Lord for the strength received from above and whose mercies have made me more merciful.

To Robert M. Johnston, my main professor/adviser, whose class in the Gospel of Mark not only inspired the writing of this dissertation, but thanks to his patience, his keen eye for undetectable detail, and for pointing out better ways to express what I wanted to say, the writing of this dissertation would have been a greater challenge. Dr. Johnston should know that, thanks to his encyclopedic mind, this dissertation has taken much more time than expected.

To my wonderful wife, who has been my strength; my children, for cheering me on, without forgetting my now-teen-age son, Mark, whose bedtime prayer "and dear Jesus, please help daddy to finish his dissertation" since he was five years old was perhaps my greatest encouragement. 


\section{CHAPTER 1}

\section{INTRODUCTION}

The Synoptic Gospels contain four settings of one account of the dominical

saying regarding “divorce." Matthew addresses the matter twice, 5:31-32 and 19:3-9; the

latter closely paralleling Mark 10:2-12. Luke, on the other hand, makes an isolated

statement in a cluster of sayings of Jesus (16:18).

A synopsis ${ }^{1}$ of the Gospels shows textual differences between Mark and Matthew

as they report on the "divorce" saying. ${ }^{2}$ The major differences are:

${ }^{1}$ For a Greek synopsis, see Synopsis Quattuor Evangeliorum, $10^{\text {th }}$ ed., ed. Kurt Aland (Stuttgart: Deutsche Bibelstiftung, 1978); for an English one, see Synopsis of the Four Gospels, $3^{\text {rd }}$ ed. (New York: United Bible Societies, 1979).

${ }^{2}$ Attempts to reconcile the differences between the Matthean and Markan accounts have only exacerbated the question. Scholarly opinions, with shades of similarities, are so varied that it would be difficult to document and comment on each one of them. See Benoît Standaert, Evvangile selon Marc commentaire: Deuxième partie Marc 6,14 à 10,52, Études Bibliques 61 (Pendé, France: J. Gabalda et $C^{\text {ie }}$, 2010), 722-729; Klemens Stock, Marco: Comentario Contestuale al Secondo Vangelo, 2nd ed. (Rome: Edizioni ADP, 2010), 194-197; Joel Marcus, Mark 8-16: A New Translation with Introduction and Commentary (New Haven, CT: Yale University Press, 2009), 33-37; Robert H. Stein, Mark, Baker Exegetical Commentary of the New Testament, ed. Robert H. Stein and Robert Yarbrough (Grand Rapids, MI: Baker Academic, 2008), 455-458; Mary Healy, The Gospel of Mark, ed. Peter S. Williamson and Mary Healy (Grand Rapids, MI: Baker Academic, 2008), 196-199; Richard M. Davidson, Flame of Yahweh: Sexuality in the Old Testament (Peabody, MA: Hendrickson, 2007), 654-657; Francis J. Moloney, The Gospel of Mark (Peabody, MA: Hendrickson, 2006), 193-196; Eugene M. Boring, Mark: A Commentary (Louisville, KY: Westminster John Knox Press, 2006), 286-288; Hendrika N. Roskam, The Purpose of the Gospel of Mark in Its Historical and Social Context (Leiden, Netherlands: Brill, 2004), 76-79; Ben Witherington III, The Gospel of Mark: A Social-Rhetorical Commentary (Grand Rapids, MI: Eerdmans, 2001), 275-278; C. S. Mann, Mark, Anchor Bible Reference Library (ABRL), ed. David Noel Freedman and William Fox Albright (Garden City, NY: Doubleday, 1986), 27:389-291. There are scholars who maintain that the two pericopes are independent from each other and that each evangelist reports separate incidents; see John M. Rist, On the Independence of Matthew and Mark (New York: Cambridge University Press, 1978), 2-4; Dungan, for a different reason, argues for the independence of the two mainly to maintain a Matthean priority. See David L. Dungan, The Sayings of Jesus in the Churches of Paul (Philadelphia: Fortress, 1971), 70, 103, 122-127. 
1. In Matthew's account (19:4-6) Jesus alludes to Gen 1:27 and quotes Gen 2:24 in response to the Pharisaic question, "Is it lawful for a man to divorce his wife for any cause?" (19:3), ${ }^{3}$ in turn eliciting another question from his enquirers: "Why then did Moses command us to give a certificate of dismissal and to divorce her?" (19:7). Mark's account contains Jesus' introduction of Moses in response to the Pharisaic question concerning the (un)lawfulness of "divorce" (10:2-3).

2. Mark lacks the Matthean statement "for any cause" (Matt 19:3b).

3. Matthew's "exception clause" $(5: 32 ; 19: 9)$ is also absent in Mark.

4. In Mark (10:10) the disciples request further explanation in private, whereas in Matthew (19:9) the explanation is given to the disciples publicly.

5. While Matthew notes that "whoever divorces his wife, except for unchastity, and marries another, commits adultery" (19:9), to the same statement Mark adds, "against her" (10:11).

6. Mark contains no comment about "eunuchs" nor does he mention the disciples' remark, "If such is the case of a man with his wife, it is better not to marry" $(19: 10)$.

7. Mark's statement, "and if she divorces her husband and marries another, she commits adultery" (10:12), is not found in Matthew. These fundamental differences may be best appreciated as shown in table 1 below.

\footnotetext{
${ }^{3}$ Unless otherwise noted, Bible quotations are from the New Revised Standard Version.
} 
Table 1. Markan - Matthean Comparison of the "Divorce" Logia

\begin{tabular}{|c|c|c|}
\hline The "Divorce" Saying & Mark 10:1-12 & Matthew 19:1-12 \\
\hline Same geographical location & $10: 1$ & $19: 1$ \\
\hline He taught the crowds & $10: 1$ & \\
\hline He cured the crowds & & $19: 2$ \\
\hline Test question by Pharisees & $10: 2$ & $19: 3$ \\
\hline "For any cause" & & $19: 3$ \\
\hline Moses introduced by Jesus & $10: 3$ & \\
\hline Moses introduced by Pharisees & & $19: 7$ \\
\hline $\begin{array}{l}\text { Allusion to Gen } 1: 27 \text { and/or } \\
\text { quotation of Gen } 2: 24\end{array}$ & $10: 7-8$ & $19: 4-6$ \\
\hline "Except for porneia" & & $5: 32 ; 19: 9$ \\
\hline "Hardness of heart" & $10: 5$ & $19: 8$ \\
\hline $\begin{array}{l}\text { "Whoever divorces his wife, } \\
\text { except for unchastity, and } \\
\text { marries another commits } \\
\text { adultery" }\end{array}$ & $\begin{array}{l}\text { 10: } 11 \text {, Mark adds, "against } \\
\text { her" }\end{array}$ & $19: 9$ \\
\hline Private explanation to disciples & $10: 10$ & \\
\hline Public explanation to disciples & & $19: 11$ \\
\hline $\begin{array}{l}\text { "If such is the case of a man with } \\
\text { his wife, it is better not to } \\
\text { marry" and commentary on } \\
\text { eunuchs }\end{array}$ & & $19: 10,12$ \\
\hline $\begin{array}{l}\text { "And if she divorces her husband } \\
\text { and marries another, she } \\
\text { commits adultery" }\end{array}$ & $10: 12$ & \\
\hline
\end{tabular}




\title{
A Brief Modern History
}

\author{
In Christian history, the interpretation of Jesus' saying on divorce has been
}

\author{
controversial. ${ }^{4}$ Through the centuries, writers of various theological persuasions have
}

\begin{abstract}
${ }^{4}$ No attempt will be made to retrace a general history of interpretation. I will summarize some of the modern scholarship on the topic. There are many fine comprehensive and detailed surveys addressing varying theological interpretations and persuasions. For a Jewish analysis, see Donald C. Polaski and Sandra Hack Polaski, "Listening to a Conversation: Divorce, the Torah, and Earliest Christianity," Review \& Expositor 106 (Fall 2009): 591-602; Michael J. Broyde, "The Covenant-Contract Dialectic in Jewish Marriage and Divorce Law," in Covenant Marriage in Comparative Perspective, ed. John Witte, Jr., and Eliza Ellison (Grand Rapids, MI: Eerdmans, 2005), 51-69; David Instone-Brewer, "Rabbinic Teaching: Increasing Grounds for Divorce," in Divorce and Remarriage in the Bible: The Social and Literary Context (Grand Rapids, MI: Eerdmans, 2002), 85-90; Michael J. Broyde, Marriage, Divorce, and the Abandoned Wife in Jewish Law (Hoboken, NJ: Ktav, 2001), 67-79. For a view prior and during the Protestant Reformation, see H. J. Selderhuis, Marriage and Divorce in the Thought of Martin Bucer, Sixteenth Century Essays \& Studies, ed. Raymond A. Mentzer, trans. John Vriend and Lyle D. Bierma (Ann Arbor, MI: Edward Brothers, 1999), 48:9-48; Martin Luther, The Babylonian Captivity of the Church, Luther's Works, American ed., ed. Jaroslav Pelikan and Helmut T. Lehmann (St. Louis: Concordia, 1955-1976), 36:11-57. For a general historical overview, see David Instone-Brewer, "What God Has Joined Together: What Does the Bible Really Teach about Divorce?" Christianity Today (CT), October 1, 2007, 26-29. For both sides of the moral dilemma in the church today, see Johnson Lim, "Divorce and Remarriage in Theological and Contemporary Perspectives," Asia Journal of Theology (AJT) 20 (2006): 271-284; Ronald J. Nydam, "The Messiness of Marriage and the Knottiness of Divorce: A Call for a Higher Theology and a Tougher Ethic," Calvin Theological Journal (CTJ) 40, no. 2 (2005): 211-226; Peter Carrell, "Marriage, Divorce, and Remarriage in the New Testament," Stimulus 11 (2003): 32-35; David Instone-Brewer, "Four Biblical Grounds for Divroce," Divorce and Remarriage in the Church: Biblical Solutions for Pastoral Realities (Downers Grove, IL: IVP Books, 2003), 93-106. For other general views, see David InstoneBrewer, "1 Corinthians 7 in the Light of the Graeco-Roman Marriage and Divorce Papyri," Tyndale Bulletin (TynBul) 52, no. 1 (2001): 101-115; Robert M. Johnston, "Unfaithfulness to the Marriage Vow," Ministry, November 1994, 14-16; Douglas Lee Riggs, "A Rhetorical-Critical Interpretation of the Divorce and Remarriage Passages in the Synoptic Gospels" (Ph.D. diss., Southwestern Baptist Theological Seminary, 1991), 6-58; Hershel Wayne House, "Divorce and Remarriage under a Variety of Circumstances: Responses," Divorce and Remarriage: Four Christian Views (Downers Grove, IL: InterVarsity, 1990), 231-248; Oscar H. Hirth, "Interpretation in the Gospels: An Examination of the Use of Redaction Criticism in Mark 8:27-9:32 Par. Matthew 16:13-17:23; Luke 9:18-45" (Th.D. diss., Dallas Theological Seminary, 1985), 1-61; Tharel Shirah, "The Teaching of the New Testament Concerning Marriage Dissolution and Subsequent Marriages" (Th.D. diss., New Orleans Baptist Theological Seminary, 1983), 84-107; Harold Ray England, "Divorce and Remarriage in 1 Corinthians 7:10-16" (Ph.D. diss., Southern Baptist Theological Seminary, 1982), 55-69; J. De Reeper, "Marriage and Divorce in Present-day Theology," American Ecclesiatical Review (AER) 16 (1974): 389-400; Hershel Wayne House, "An Investigation of the New Testament Teaching on Divorce and Remarriage from a Biblical-Historical Perspective" (Th.M. thesis, Western Conservative Baptist Seminary, 1974), 44-62; David R. Catchpole, "The Synoptic Divorce Material as a Traditio-Historical Problem," Bulletin of the John Rylands University Library of Manchester (BJRL) 57 (Autumn 1974): 92-127; Henri Crouzel, "Le texte patristique de Matthieu v.32 et xix.9," New Testament Studies (NTS) 19 (October 1972): 98-119; Viggo Norskov Olsen, The New Testament Logia on Divorce: A Study of Their Interpretation from Erasmus to Milton (Tübingen: Mohr [Siebeck], 1971), 23-46; Henri Crouzel, L'église primitive face au divorce du premier cinquième siècle (Paris: Beauchesne, 1971), 51-64; Anthony J. Bevilacqua, "History of the Indissolubility of Marriage," Proceedings of the Catholic Theological Society of America 22 (1967): 253-308; William Graham Cole, "The Church and Divorce: Historical Background," Pastoral Psychology 9 (September 1958): 39-44; John
\end{abstract}


attempted to ascertain what Jesus might have meant and, furthermore, to specify the application of that teaching to the Church. ${ }^{5}$ Such application has been offered in varying degrees, from an absolutist position barring divorce under any circumstance, pointing to the creation order, to a more "progressive" view which allows not only divorce for any cause, but also remarriage. This wide spectrum of persuasions appeals to the same biblical texts for their authority. ${ }^{6}$ Psychiatrist Basil Jackson's opening address in the last

Calvin, Commentary on the Harmony of the Evangelists Matthew, Mark and Luke, trans. William Pringle (Grand Rapids, MI: Eerdmans, 1949), 2:385-387; George Hayward Joyce, Christian Marriage: An Historical and Doctrinal Study, 2nd ed. (London: Sheed \& Ward, 1948), 39-50; Shepherd Braithwaite Kitchin, A History of Divorce (London: Chapman Hall, 1912), 71-79; Kirsopp Lake, "The Earliest Christian Teaching on Divorce," Expositor 10 (1910): 416-427; Herbert Mortimer Luckock, The History of Marriage, Jewish, and Christian, in Relation to Divorce and Certain Forbidden Decrees (New York: Longmans, Green, 1895), 33-47; Huldreich Zwingli, "Annotationes Huldrici Zwingli in Evangelium Matthaei," in Huldrici Zwingli Opera, ed. Mehciore Schulero and Io. Schulthessio (n.p.: Turici ex Officina Schulthessiana, 1836), 1:345-137; David W. Jones, "The Betrothal View of Divorce and Remarriage," Bibliotheca Sacra 165 (January-March 2008): 68-85. For perhaps the most complete OT analysis, see Davidson, Flame, 377-423.

${ }^{5}$ Many may tend to believe that the Church in the early centuries had a consensus on the question of divorce and remarriage. Harrell shows this not to be the case. See Pat Edwin Harrell, Divorce and Remarriage in the Early Church: A History of Divorce and Remarriage in the Ante-Nicene Church (Austin, TX: Sweet, 1967), 174-192; cf. J. P. Arendzen, “Ante-Nicene Interpretations of the Sayings on Divorce," Journal of Theological Studies (JTS) 20 (1919): 230-241; John W. Decker, "Marriage and Divorce in the Early Christian Church” (Ph.D. diss., Southern Baptist Theological Seminary, 1917), 12-45.

${ }^{6}$ See Polaski and Polaski, "Listening," 591-602; John F. Brug, "The Betrothal Explanation of Porneia in the Exception Clause," Wisconsin Lutheran Quarterly (WLQ) 105 (Fall 2008): 290-293; D. W. Jones, "Betrothal View," 68-85; Instone-Brewer, "Joined Together," 26-29; Johnson Lim, "Divorce and Remarriage," 271-288; Lauren F. Winner, "After Divorce," Christian Century, 123 (2006): 21-22; Nydam, "Messiness," 211-226; Glen G. Scorgie, The Journey Back to Eden: Restoring the Creator's Design for Women and Men (Grand Rapids, MI: Zondervan, 2005); Kenneth R. Himes and James A. Coriden, "The Indissolubility of Marriage: Reasons to Reconsider," Theological Studies 65 (2004): 453-499; Helen M. Luke, "The Marriage Vow," Parabola 29 (Spring 2004): 49-51; Fulata Mayo, "Can Divorce Be a Solution to Marital Problems in a Christian Marriage?" Ecumenical Review 56, no. 4 (October 2004): 437-447; David M. McCarthy, Becoming One Flesh: Marriage, Remarriage, and Sex (Malden, MA: Oxford University Press, 2004); Peter Carrell, "Remarriage," 32-35; Julie Hanlon Rubio, "Three-In-One-Flesh: A Christian Reappraisal of Divorce in Light of Recent Studies," Journal of the Society of Christian Ethics 23 (Spring-Summer 2003): 47-70; Instone-Brewer, "Biblical Grounds," 93-106; William Heth, "Jesus on Divorce: How My Mind Set Has Changed," Southern Baptist Journal of Theology (SBJT) 6 (Spring 2002): 4-29; Gordon J. Wenham, "Does the New Testament Approve Remarriage after Divorce?" SBJT 6 (Spring 2002): 30-45; James M. Weibling, "Reconciling Matthew and Mark on Divorce," Trinity Journal (TJ) 22 (2001): 219-235; David L. Smith, "Divorce and Remarriage in Church History," Didaskalia (Did) 11 (Spring 2000): 59-75; Samuel Bacchiocchi, Divorce and Remarriage Today (Berrien Springs, MI: Biblical Perspectives, 2000), 35-40; and his Divorce and Remarriage in Matthew (Berrien Springs, MI: Biblical Perspectives, 2000); Richard M. Davidson, "Divorce and Remarriage in the Old Testament: A Fresh Look at Deuteronomy 24:1-4," Journal of the Adventist Theological Society (JATS) 10, no. 1-2 (1999): 2-22; 
known conference of its kind, which brought together a variety of experts from the fields of psychiatry, law, and theology (Jewish and Christian) to deal with the vexing problem of divorce and remarriage, is right to say that: "No matter how erudite the theologian is ... one's emotional background, one's preconceived notions, one's preconceived ideas result in some degree of eisegesis. I will get out of the exceptive clause, for example, to some degree the conditioning I bring to it." "7 Perhaps Perrin explained it best when he observed: "Even when we have considered the historical and literary criticism of a text, and the insights of the philosopher's language, we have still not yet reached the end of

Andrew Cornes, Divorce and Remarriage: Biblical Principles and Pastoral Care (Grand Rapids, MI: Eerdmans, 1993); House, Divorce and Remarriage, 15-54, 73-129; H. G. Coiner, "Those Divorce-Marriage Passages (Matt 5:32; 19:9; 1 Cor 7:10-16," Concordia Theological Monthly (CTM) 39 (1988): 367-384; Stanley B. Marrow, "Marriage and Divorce in the New Testament," Anglican Theological Review (AthR) 70 (1988): 3-15; David C. Holwerda, "Jesus on Divorce: An Assessment of a New Proposal," CTJ 22 (1987): 114-120; William F. Luck, Divorce and Remarriage: Recovering the Biblical View (San Francisco: Harper \& Row, 1987); Robert Westbrook, "The Prohibition on the Restoration of Marriage in Deut 24:1 4," Studies in the Bible, Scripta Hierosolymitana, ed. S. Japhet (Jerusalem: Magnes Press of Hebrew University, 1986), 31:77-101; William A. Heth and Gordon J. Wenham, Jesus and Divorce: The Problem of the Evangelical Consensus (Nashville: Nelson, 1985); Carl J. Laney, "Divorce and the Christian Minitry (1Tim. 3:2, 12 and Titus 1:6)," The Divorce Myth (Minneapolis: Bethany House, 1981), 91-102; Larry Richards, Marriage: A Healing Gift from God (Waco, TX: Word, 1981); George J. Wenham, "The Syntax of Matt 19:9," Journal for the Study of the New Testament (JSNT) 28 (1986): 17-23; Ben Witherington III, "Matthew 5:32 and 19:9: Exception or Exceptional?" NTS (1985): 571-576; see George J. Wenham's other essays, "May Divorced Christians Remarry?" Churchman 95 (1981): 152-153; "The Biblical View on Marriage and Divorce: OT Teaching," Third Way 23 (Nov. 3, 1977): 2-13; "The Restoration of Marriage Reconsidered," Journal of Jewish Studies (JJS) 30 (1979): 36-40; see also Richard N. Soulen, "Marriage and Divorce: A Problem in NT Interpretation," Interpretation (Int) 23 (1969): 439-450; Walter J. Bartling, "Sexuality, Marriage, and Divorce in 1 Corinthians 6:12-7:16," CTM 39 (1968): 355-366; Victor J.

Posphishil, Divorce and Remarriage: Towards a New Catholic Teaching (New York: Herder and Herder, 1967), 40-56; Henri Crouzel, "Divorce and Remarriage in the Early Church: A Propos of a Recent Book," Irish Theological Quarterly (ITQ) 38 (1971): 21-41; Victor J. Posphishil, "Divorce and Remarriage in the Early Church," ITQ 38 (1971): 338-347; Edward Schillebeeckx, Marriage: Human Reality and Saving Mystery, trans. N. D. Smith (New York: Sheed and Ward, 1965); Leonard F. Gerke, Christian Marriage: A Permanent Sacrament (Washington, DC: Catholic University Press, 1965); John J. O'Rourke, “A Note on an Exception: Mt 5:32 (19:9) and 1 Cor 7:12 Compared," Heythrop Journal 5 (1964): 299-302; Thomas V. Fleming, "Christ and Divorce," Theological Studies (TS) 1 (1963): 106-120; Jean-Jacques von Allmen, Pauline Teaching on Marriage (New York: Morehouse-Barlow, 1963); Patrick J. O'Mahoney, "The Unbreakable Bond," Catholics and Divorce, ed. Patrick J. O’Mahoney (London: Thomas Nelson \& Sons, 1959), 14-17; John Murray, Divorce (Philadelphia: Orthodox Presbyterian Church, 1953).

${ }^{7}$ In a report by Dennis E. McFadden, “Just What Did Jesus Say about Divorce?” CT (November 20, 1981), n.p. 
the complexities involved in the interpretation of a particular text." ${ }^{8}$ Wenham, in an about-face from some of his previous presuppositions on divorce, now cautions, "It is unwise to be dogmatic as far as marriage and divorce are concerned [considering that] the Synoptic gospels do not even agree with each other about what he [Jesus] actually said."9 Here is a brief overview of some of the modern voices on the question of divorce and remarriage in the Synoptic Gospels, mainly Mark and Matthew. ${ }^{10}$

\section{Did He Say It?}

No discussion would appear to be complete without considering one of the most imposing personalities in twentieth-century NT scholarship: Rudolf Bultmann. To Bultmann the saying of Jesus on divorce in Mark is an "artificial construction" on the basis that it begins "with a question without any reference to any act," and that this is so because the whole concept of divorce would not be "used as a basis for interrogation as was their [Jesus' and disciples] eating with unwashed hands." ${ }^{\prime 1}$ Bultmann does not seem to accept the "divorce" saying as authentic in the life of Jesus as it appears in the Gospel

\footnotetext{
${ }^{8}$ N. Perrin, "Toward an Interpretation of the Gospel of Mark," in Christology and a Modern Pilgrimage: A Discussion with Norman H. Perrin, ed. D. Betz (Claremont, CA: New Testament Colloquium, 1971), 65-66.

${ }^{9}$ G. J. Wenham, "Marriage and Divorce in the Old Testament," Did 1 (November 1989): 9.

${ }^{10}$ No attempt will be made to address the authenticity or non-authenticity of the Synoptic saying on "divorce." I assume that Jesus made a statement concerning it which many scholars have affirmed based on what has been termed "the criterion of multiple attestations." That Jesus made some kind of statement concerning "divorce" has been attested by the Synoptists and Paul. For more, see John P. Meier, Law and Love, vol. 4 of A Marginal Jew: Rethinking the Historical Jesus, ABRL (New Haven, CT: Yale University Press, 2009), 4:112-119; Gerd Thiessen and Dagmar Winter, "The Enlightenment: Critical Method as the Reconstruction of the History behind the Text," The Quest for the Plausible Jesus: The Question of Criteria (Louisville, KY: Westminster John Knox, 2002), 32-37; Stanley E. Porter, The Criteria for Authenticity in Historical-Jesus Research: Previous Discussion and New Proposals (Sheffield: Sheffield Academic Press, 2000), 86-89; Marrow, "Marriage and Divorce," 8-9.

${ }^{11}$ Rudolf Bultmann, The History of the Synoptic Tradition, rev. ed., trans. John Marsh (Peabody, MA: Hendrickson, 1994), 26-27.
} 
of Mark; rather, he asserts that the pericope "is made of material from the polemics of the Church." 12 That the whole debate is a post-Easter invention of the Church has also been supported by others. ${ }^{13}$ Schweizer puts it this way: "This entire passage is representative of the kind of controversy in which the church frequently was engaged . . . in its quarrel with Judaism"; ${ }^{14}$ to which Yarbro-Collins concurs: "The artificiality of this introduction to the dialogue may indicate either that the evangelist needed to create a setting for a saying attributed to Jesus or that the whole dialogue has its social setting in the early church."15 To Bultmann, quotations such as Mark 10:9 and Matt 19:6 are not authoritative, binding prohibitions but worldly-wise advice in the same vein as Sirach 7:25, "marry your daughter and you shall have performed a weighty matter."16 Bultmann considered that the Synoptic divorce pericopes presented Jesus as a teacher of wisdom, rather than a lawgiver. He states, "The Synoptics exhibit the same forms . . . as the proverbial wisdom of the Old Testament and of the Jewish literature." That verses such

\footnotetext{
${ }^{12}$ Ibid., 27.
}

${ }^{13}$ See Moloney who implies that "in the house" (Mark 10:10) "called to mind the Church which gathered in homes just as the first disciples had often gathered around Jesus in the house." Mark, 198. Cf. Kirsten Standahl, The School of St. Matthew and Its Use of the OT (Philadelphia: Fortress, 1968), 148; and W. D. Davies and Dale C. Allison, A Critical and Exegetical Commentary on the Gospel according to Saint Matthew, ICC (Edinburgh: T \& T Clark, 1988/1997), 1:124.

${ }^{14}$ Eduard Schweizer, The Good News according to Mark, trans. Donald H. Madvig (Richmond, VA: John Knox, 1970), 201.

${ }^{15}$ Adela Yarbro Collins, Mark: A Commentary, ed. Harold W. Attridge, Hermeneia: A Critical and Historical Commentary on the Bible (Minneapolis: Fortress, 2007), 465. Collins adds that "another possibility is that the [Markan] dialogue arose in some of the communities of the followers of Jesus after his death in response to a tendency toward sexual continence." Ibid., 468. Carrington suggested that "the units [Markan pericopes] were used as lectionary sections in the services of the church," Phillip Carrington, The Primitive Christian Calendar: A Study in the Making of the Markan Gospel (Cambridge: University Press, 1952), 58. This concept was rejected by Bowman who states that "[lectionaries] do not provide a real reason for the formation of the gospel." John Bowman, The Gospel of Mark: The New Christian-Jewish Passover Haggadah, Studia Post-Biblica, ed. P. H. A. DeBoer (Leiden, Netherlands: Brill, 1965), 8:102.

\footnotetext{
${ }^{16}$ Bultmann, History, 70 .
} 
as Mark 10:9, "What therefore God has joined together, let not man put asunder," are said to parallel verses such as Prov 18:22b (LXX), "he who puts away a good wife ['єк $\left.\beta \alpha^{\prime} \lambda \lambda \epsilon \iota\right]$ puts away a good thing," and Sirach 7:26, "do you have a good wife after your own heart?, do not forsake her," ${ }^{, 17}$ are good parallels to the genre of Jesus' proverbial sayings. ${ }^{18}$ Scholars such as Stock agree with Bultmann in that all of Mark 10 "shows characteristics ... something like family rules of conduct which provide guidance for various groups." ${ }^{19}$ Fischer does not see any legal pronouncements in the teaching of Jesus when he observes that "if any of them is in the genre of legal statement, it is odd that no penalty is attached, there is no evidence of a court system to enforce the sayings, to the contrary, the literary form is always closer to proverb than to legal statements, and so the assumption should be that such sayings functioned as advice to individuals and community in the period of the formation of the gospels." 20 To the question as to who may have been keeping records of divorce proceedings in the NT period, Swidler dismisses the possibility that anyone was actually following legal proceedings, claiming that "courts seem to have become involved only because of financial complications" in a

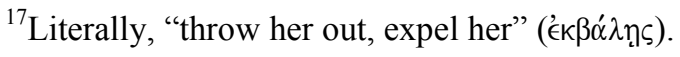

${ }^{18}$ Bultmann, History, 70.

${ }^{19}$ Augustine Stock, The Method and Message of Mark (Wilmington, DE: Michael Glazier, 1989), 264.

${ }^{20}$ James A. Fischer, "1 Cor 7:8-24: Marriage and Divorce," Journal of the Chicago Society of Biblical Research 23 (1978): 33; although Davis considers that "by the addition 'for any cause' to the Marcan version, Matthew has brought the question of divorce into the realm of strict legal discussion." W. D. Davis, The Setting of the Sermon on the Mount (Cambridge: University Press, 1964), 104.
} 
limited number of cases, and that divorce was mostly a private matter between a man and his (in the possessive sense) wife. ${ }^{21}$

\section{Jesus and the Rabbis}

Many consider that the background in Matthew's version on "divorce" centers around the debates between the Hillel and Shammai schools as expressed in the Mishnah and the Talmud, ${ }^{22}$ and that in that debate, Jesus came down on the side of Shammai. ${ }^{23}$ Instone-Brewer, perhaps the latest scholar to have made an in-depth analysis on the question of Jewish divorce practices, surmises that the divorce sayings in the Gospels are related to the so-called "invalid divorces." He considers that the crux of the Synoptic statements is a reaction to the "easy divorce" espoused by the Hillelite school. ${ }^{24}$ Bailey, in a line of scholars who had proposed this, ${ }^{25}$ states: "So indefensible, however, is putting away for a trivial cause that our Lord will not recognize it as divorce; he who marries

\footnotetext{
${ }^{21}$ Leonard J. Swidler, Women in Judaism (Metuchen, NJ: Scarecrow, 1976), 154-155. For an expanded view concerning other proceedings connected with a first-century Jewish divorce, see Leo J. Purdue, "Marriage, Divorce, and Family in Second Temple Judaism," in Families in Ancient Israel, ed. Leo G. Purdue, Joseph Blenkinsopp, John J. Collins, and Carol Meyers (Louisville, KY: Westminster John Knox 1997), 115-117; also Joachim Jeremias, Jerusalem in the Time of Jesus, trans. F. H. Cave and C. H. Cave (Philadelphia: Fortress, 1969), 370-372.

${ }^{22}$ For which Daube has called Matthew, "a rabbinic gospel." The New Testament and Rabbinic Judaism (New York: Arno Press, 1973), 60; cf. Roy Gane, “Old Testament Principles Relevant to Divorce and Remarriage," JATS 12, no. 2 (Autumn 2001): 48-49; cf. Catchpole, "Synoptic Divorce," 93-94.

${ }^{23}$ See Helmut Merkel, “Jesus und die Pharisäer," NTS 14 (1968): 207; cf. Reinhart Hummel, Die auseinandersetzung zwischen Kirche und judentum im matthäusevangelium (Munich: Chr. Kaiser, 1966), 49-51.

${ }^{24}$ See Instone-Brewer, "Jesus' Teaching: Divorce on Biblical Grounds Only," in Divorce and Remarriage in the Bible: The Social and Literary Context (Grand Rapids, MI: Eerdmans, 2002), 133-188.

${ }^{25}$ Among those, see Joseph A. Fitzmyer, The Gospel according to Luke, ABRL (New York: Doubleday, 1981), 2:1121; William L. Lane, The Gospel according to Mark, New International Commentary on the New Testament (NICNT) (Grand Rapids, MI: Eerdmans, 1974), 353-355; Daube, Rabbinic Judaism, 83-87; William F. Albright and Christopher S. Mann, Matthew: Introduction, Translation, and Notes, ABRL (New York: Doubleday, 1971), 26:65-67; Bennet Harvie Branscomb, The Gospel of Mark (London: Hodder \& Stoughton, 1952), 177-179.
} 
someone who has been put away really enters into relations with one who is still a wife, and therefore commits adultery." 26

At the center of the Hillel-Shammai debate on divorce, it has been pointed out, ${ }^{27}$ sits the so-called Matthean exception clause, "except for unchastity" (19:9), which supposedly liberates the strictness of the Markan account that seemingly leaves no room for divorce. ${ }^{28}$ In the middle of the twentieth century, Vawter had argued that $\pi \alpha \rho \in \kappa \tau$ ó $\varsigma$

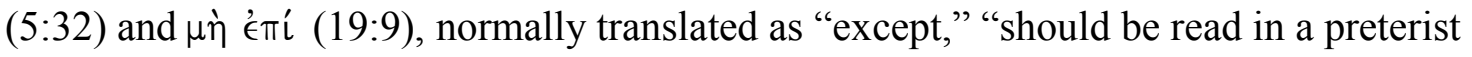

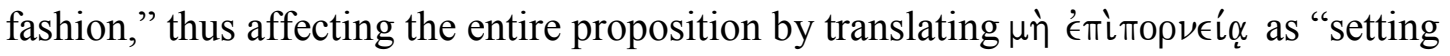
aside the matter of porneia." 29

This proposition has been rejected by a large number of NT scholars, ${ }^{30}$ and later

\footnotetext{
${ }^{26}$ Derrick Sherwin Bailey, The Mystery of Love and Marriage (New York: Harper \& Brothers, 1952), 91 .
}

${ }^{27}$ Neufeld takes exception to this by stating, "I suggest that in no Synoptic divorce saying is any Jewish debate the primary historical background." Edmund Neufeld, "Marriage after Divorce in Early Judaism," Did 1 (1989): 26.

${ }^{28}$ A good summary of this position may be found in Raymond F. Collins, Divorce in the New Testament (Collegeville, MN: Liturgical, 1992), 199-206.

${ }^{29}$ Bruce Vawter, "The Divorce Clause of Mt 5, 32 and 19, 9," Catholic Biblical Quarterly (CBQ) 16 (1954): 163.

${ }^{30}$ Goulder prefers to translate porneia as "adultery" since "in Matthew Jesus appears as a rabbi of the school of Shammai." See Michael D. Goulder, Midrash and Lexicon in Matthew (London: SPCK, 1974), 18; while Fitzmyer prefers the meaning of "an incestuous marriage," "a live issue for Gentiles entering the Matthean church." See Joseph Fitzmyer, "The Matthean Divorce Texts and Some New Palestinian Evidence," TS 37 (1976): 108-109, 112-115. In order to ascertain what Matthew or the Church may have wanted to convey by the term porneia, Janzen calls for the need for a more precise meaning. See David Janzen, "The Meaning of Porneia in Matthew 5:32 and 19:9: An Approach from the Study of Ancient Near Eastern Culture," JSNT 80 (2000): 66-80, where he argues that the term porneia has a much wider semantic range than the usual translation of "adultery." Cf. Friedrich Hauck and Siegfried Schulz,

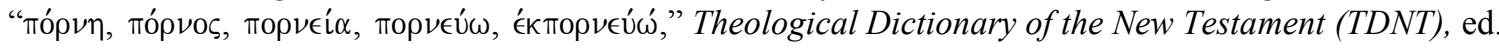
Gerhard Friedrich, trans. Geoffrey Bromiley (Grand Rapids, MI: Eerdmans, 1964-1976): 6:579-595. Other scholars have argued, for example, that the absence of porneia in Acts 15 is a prohibition against sexual relationships among blood relatives. See F. F. Bruce, The Acts of the Apostles (Grand Rapids, MI: Eerdmans, 1952), 300; Earnest Haenchen, The Acts of the Apostles: A Commentary, trans. Robert M. Wilson (Philadelphia: Westminster, 1971), 449; cf. Craig C. Blomberg, "Marriage, Divorce, Remarriage, and Celibacy: An Exegesis of Matthew 19:3-12," TJ 11 (1990): 177-181. Janzen, on the other hand, has 


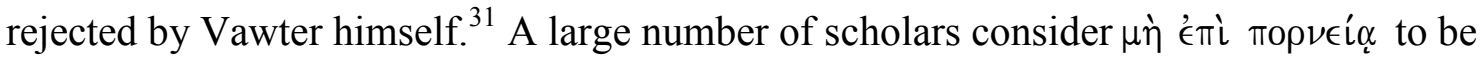
an interpretative addition by Matthew or inserted into the Gospel by the Church. ${ }^{32}$

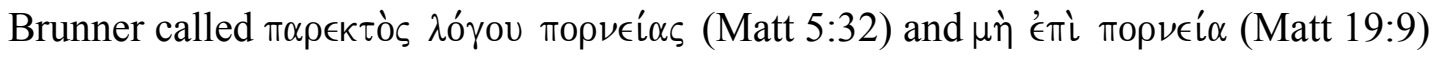
"interpolations by the Early Church"; ${ }^{33}$ while T. W. Manson called them "not part of the genuine teaching of Jesus." ${ }^{, 34}$ Bowman also sees "Matthew's handling of the Marcan material and his additions there to bear the mark of ecclesiatism,"35 while Filson believes that "Matthew adapts his teaching to support the stricter line of Jewish teaching," position that finds support in Jeremias, ${ }^{37}$ and earlier supported by $\mathrm{Grant}^{38}$ and Creed. ${ }^{39}$ Lehmann, however, argues that the "saving clause 'except for fornication' is the

argued that the Hebrew counterpart to porneia, $z^{e}$ nut , and its related nouns do not deal with incestuous marriages but to prostitution and mostly in an allegorical sense of Israel's abandonment of Yahweh. See Janzen, "Porneia," 70-71. For the most recent and thorough analysis of its Hebrew counterpart ('erwat dabar), see Davidson, Flame, 391-393.

${ }^{31}$ See Bruce Vawter, "Divorce in the New Testament," $C B Q 39$ (1977): 528-542.

${ }^{32}$ See Brug, "Betrothal Explanation," 290-293; Barbara E. Reid, The Gospel according to Matthew (Collegeville, MN: Liturgical Press, 2005), 168; Instone-Brewer, “Jesus' Teaching,” 134; Allen R.

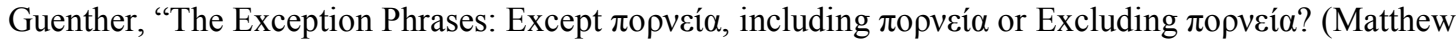
5:32; 19:9)," TynBul 53 (2002): 83-96; David Janzen, "Porneia," 66-80; Davies and Allison, St. Matthew, $1: 131$.

${ }^{33}$ Emil Brunner, The Divine Imperative (Philadelphia: Westminster, 1947), 651.

${ }^{34}$ Thomas Walter Manson, The Teachings of Jesus (Cambridge: Cambridge University Press, 1951), 200. Brunner and Manson followed Plummer who very early in the $20^{\text {th }}$ century wrote that "the exceptive clauses were never uttered by Jesus." Alfred Plummer, An Exegetical Commentary on the Gospel according to St. Matthew (London: Elliot Stock, 1909), 81.

${ }^{35}$ Bowman, Mark, 210. Bowman (210) also finds that Matthew added such sayings: "not expedient to marry" (19:10), "eunuchs" (19:12), and "he who is able to receive this, let him receive it" (19:12).

${ }^{36}$ Floyd V. Filson, A Commentary on the Gospel according to St. Matthew (New York: Harper \& Brother, 1960), 207.

${ }^{37}$ Jeremias, Jerusalem, 413.

${ }^{38}$ Frederick C. Grant, "The Mind of Christ in Marriage," in Five Essays on Marriage (Louisville, KY: Cloister, 1946), 33-35.

${ }^{39}$ John M. Creed, The Gospel according to St. Luke (London: Macmillan, 1957), 208. 
cardinal point in [Matthew's] general legal discussion [and that it] cannot be a scribal interpolation. . . [and that] the omission of the conditional clause in Mark and Luke must be called the scribal error, not the reverse, as has been held till now." 40 Carson, who accepts the originality of the Matthean clause, says that the phrase without the clause becomes nonsensical: "anyone who divorces commits adultery [?].” To Carson, "the exception clause must therefore be understood to govern the entire protasis."

Davidson, who accepts the exception clause as part of Jesus' original teaching, considers that "porneia has a much narrower focus, referring exclusively to illicit sexual intercourse, which in the Mosaic law called for the offender being cut off from God's people (Lev 18:29)."42 He clarifies his statement by quoting Gane who states, "Jesus says that whereas Moses allowed for divorce for indecent exposure without illicit sexual relations, He permits divorce only if illicit sexual relations take place.”,

Fitzmyer, writing from a Roman Catholic perspective, finds the Matthean additions, whether by Matthew or by the Church, justified on the basis that if Matthew was "moved to add an exceptive phrase to the saying of Jesus about divorce that he found in an absolute form in either his Marcan source or in 'Q,' or if Paul likewise under inspiration could introduce into his writing an exception on his own authority, then why cannot the Spirit-guided institutional Church of a later generation make a similar

${ }^{40}$ Manfred R. Lehmann, "Gen 2:24 as the Basis for Divorce in Halakhah and New Testament," Zeitschrift für die alttestamentliche Wissenschaft 72 (1960): 266.

${ }^{41}$ D. A. Carson, "Matthew," The Expositor's Bible Commentary, ed. F. E. Gaebelein (Grand Rapids, MI: Zondervan, 1984), 8:416.

${ }^{42}$ Davidson, Flame, 655.

${ }^{43}$ Gane, Principles, 47-48, quoted in Davidson, Flame, 655. 
exception?"44 Brunt, holding that "there is good reason to believe that the so-called exception clause, 'except for infidelity' is added by Matthew and that does not reflect the original words of Jesus," offers the mediating stance that "gospel writers, under inspiration, have modified their material to communicate God's will to their particular audience. 45

There are those, however, who suggest that neither the Markan or Matthean internal evidence nor rabbinic writings seem to make the indissolubility of marriage and subsequent remarriage the crucial issue that some Synpotic commentators or the Church may make it out to be. ${ }^{46}$ Neufeld contends that the Mishnaic tractate Gittin contains seventy-five paragraphs and only the very last one (9.10), in a few short lines, reports the different opinions of the Hillelite and Shammaite schools, that they "certainly spend a considerable amount of time discussing issues in much greater detail than they do Deut 24:1." As to the assumption that Jesus' was responding to "easy divorce" practices, there are still those who will contest that divorce was frowned upon and carried some kind of a stigma, and while not rare, neither was it rampant. ${ }^{48}$

\section{No Divorce-No Remarriage}

Of course, there are others who interpret Jesus' Markan statement on "divorce" in

${ }^{44}$ Fitzmyer, "Matthean Divorce," 224; cf. Coiner, "Those Passages," 367-384.

18.

${ }^{45}$ John C. Brunt, "What Does the New Testament Say About Divorce?" Spectrum 13 (June 1983):

${ }^{46}$ See Lane, Mark, 353-354, and Albright and Mann, Matthew, 26:65-69.

${ }^{47}$ Neufeld, "Marriage after Divorce,” 29; cf. Instone-Brewer, "Rabbinic Teaching," 85-87.

${ }^{48}$ See Samuel Safrai, Michael Stern, David Flusser, and Willem Cornelius van Unnik, The Jewish People in the First Century, Compendia rerum Indicaram ad Novum Testamentum (Assen, Netherlands: Von Gourcum, 1974-1976), 2:790-791; cf. Jeremias, Jerusalem, 370-371. 
a much stricter way. ${ }^{49}$ Healy is one of many voices that have interpreted the Synoptics' teaching in an absolutist way. She says, "No human being is authorized to dissolve that bond once it has been made ... [and that] on his own authority Jesus has just taken away a concession given in the law of Moses." ${ }^{, 50}$ In the same vein Moloney suggests that "as Jesus breaks onto the scene proclaiming the advent of the kingdom of God (1:14-15) [and] the restoration of God's original design initiated," ${ }^{, 51}$ divorce, as such, is no longer permitted under the new rules of the kingdom. Hooker posits that the general attitudes among the people towards divorce in the first century CE were much stricter than those espoused by the rabbinic schools of the time. ${ }^{52}$

Martin, for example, considers that the Jesus of the Markan account is challenging the rabbinic views in his "concern to uphold the ideal of indissolubility of marriage . . on God's primal intention declared in his paradise will [Gen 2:24; cf. Mark 10:6-9], that marriage is an equal partnership and expresses a life-long commitment on both sides." Martin finds Jesus' sayings on marriage binding for as long as the couple lives and that any other meaning distorts God's view of marriage. ${ }^{53}$

Martin has been echoed by others. Jewett, for example, seems to stretch this concept by stating that "Jesus did not appeal to any technical hermeneutical principle

${ }^{49}$ See Heth and Wenham, Jesus and Divorce, 36-52; G. J. Wenham, "Syntax," 17-23; Bevilacqua, "History of Marriage," 253-259; Bacchiocchi, Divorce Today, 35-40; and his Divorce in Matthew, 60-82. Wenham, however, has mediated his stance. See G. J. Wenham, “Does the NT Approve," 30-45; G. J. Wenham, "Marriage and Divorce," 6-17.

${ }^{50}$ Healy, Mark, 197-198.

${ }^{51}$ Moloney, Mark, 194.

${ }^{52}$ See Morna Dorothy Hooker, The Gospel according to St. Mark (London: A \& C Black, 1991), 235 .

\footnotetext{
${ }^{53}$ Ralph P. Martin, Mark: Evangelist and Theologian (London: Paternoster, 1972), 221.
} 
[when he] appealed to Scripture against Scripture" in quoting Gen 1:27 and 2:24 (Mark 10:6-9). To Jewett, Jesus' appeal to Moses in Mark (10:3) and his "hardness of heart" statement (Mark 10:5) "reflects the cultural, historical realities of life in ancient Israel, not the will of God as originally revealed in Creation;" and that divorce was not something God had envisioned in the creation of Adam and Eve (Mark 10:6) since that would imply a perversion of his original intention of a monogamous and permanent union.

The main emphasis of many scholars is that neither polygamy nor divorce was part of God's original design, but were introduced because of this "hardness of heart.",54 In the same line of thinking, Keenan, among others, theologizes that by virtue of the cross divorce should not exist, since a follower of Christ "recovers the primordial relationship" God established in Eden. He states: "The oneness of the flesh exists from the beginning, before the onset of sclerosis of the heart. ... Thus Jesus recommends a recovery of that primordial relationship by an abandonment of hardened fixations upon self-definitions."

Whereas Painter reads Jesus allowing for divorce, he considers that he did not legitimize remarriage. ${ }^{56}$ Witherington, not taking exception to this position, appears much more forceful as he appeals to the "one flesh" theme of Mark 10:8 in Jesus' appeal to Gen 2:24 when he writes, "What is interesting about this whole verse is not just the strictness of it, for Jesus seems to assume that the first one-flesh union is still in force

\footnotetext{
${ }^{54}$ See Stein, Mark, 456; Moloney, Mark, 196-197; Witherington, Mark, 276; Paul K. Jewett, Man as Male and Female: A Study in Sexual Relationships from a Theological Point of View (Grand Rapids, MI: Eerdmans, 1975), 136-137.

${ }^{55}$ John P. Keenan, The Gospel of Mark: A Mahayana Reading (Maryknoll, NY: Orbis, 1995), 235; cf. Healy, Mark, 197; Moloney, Mark, 194; Witherington, Mark, 277.

${ }^{56}$ John Painter, Mark's Gospel (London: Routledge, 1997), 142.
} 
even after the divorce, hence the second marriage is an act of adultery. . . . The upshot of the teaching here is that while Jesus recognizes the realities of divorce, he does not think this legitimizes remarriage if the original couple were joined together by God in the first place. ${ }^{57}$ While scholars such as Davidson may be correct to argue from Gen 2:23-24 for marriage's covenantal nature, based on the "one flesh" motif, ${ }^{58}$ Heaton's implied pungent question asks: Since when did the Jewish schools interpret Gen 2:24 even as monogamy? “The folk of the OT were clearly not monogamous," writes Heaton. "In medieval interpretation the two wives of Jacob [and his concubines], and the 700 of Solomon were interpreted as special dispensations, this was not, however, historically correct.",59

\section{For the Kingdom's Sake}

Quesnell offers an interesting view. He considers that a woman or wife is among the list of persons and things which a man may leave for the sake of the kingdom of heaven. He bases his observations on the Lukan statement, "Truly, I say to you, there is no man who has left house or wife or brothers or parents or children, for the sake of the kingdom of God" (18:29). He notes that Mark 10:29, stated in the general context of the pericope on "divorce," does not include "wife," and neither does Matthew (19:29), also in the same "divorce" context.

\footnotetext{
${ }^{57}$ Witherington, Mark, 277-278; cf. Davidson, Flame, 656.

${ }^{58}$ See Davidson, Flame, 377-381.

${ }^{59}$ Eric William Heaton, Everyday Life in OT Times (New York: Charles Scribner's Sons, 1956), 69; cf. Christopher N. L. Brooke, The Medieval Idea of Marriage (Oxford: Oxford University Press, 1989), 41-44. In the above volleying, Davidson et al. argue from God's original Edenic, pre-fall divine will, while Heaton and others react to the historical realities in which God's men were not always monogamous as the patriarchal, Israelite, and later Jewish history/narratives confirm in and outside the biblical texts.
} 
Quesnell suggests that Luke took this idea from “Q," but both Mark and Matthew omitted it. According to Quesnell, the leaving of one's wife according to the kingdom motif is clearly seen when comparing Matt 10:37-42 with Luke 14:26-27. The latter reads, "If any one comes to me and does not hate his own father and mother and wife [emphasis supplied] and children and brothers and sisters, yes, and even his own life, he cannot be my disciple," but that Matthew changed this to, "He who loves father or mother more than me is not worthy of me; and he who loves son or daughter more than me is not worthy of me."

Quesnell notes that Luke has four items to be renounced: brothers, sisters, wife, and life. The items listed in Matthew in renunciation of those who are entering into the kingdom are "houses or brothers or sisters or father or mother or children" (Matt 19:29). Earlier in Matt 10:37 Jesus had taught about loving "father or mother . . . son or daughter more than me," and even one's own life (Matt 10:39), yet in neither statement does Matthew mention losing one's wife for the kingdom's sake. Quesnell notes that this shows clearly Matthew's own reinterpretation of Jesus' logion on divorce. ${ }^{60}$

An additional point made by Quesnell that appears to support his position may be seen in the Lukan story of the great feast (14:15-24). Here again, in the midst of the kingdom motif, the invited guests excuse themselves from coming by saying, "I have bought a field" (14:18), "I have bought five yoke of oxen" (14:19), "I have married a wife and on account of this I cannot come" (14:20). Quesnell notes that Matthew (22:5)

\footnotetext{
${ }^{60}$ See Quentin Quesnell, “Made Themselves Eunuchs for the Kingdom of Heaven (Matt 19:12)," CBQ 30 (July 1968): 345.
} 
preserves the first two items but omits the third, suggesting that in the original "Q" saying taking a wife might interfere with following the call of the kingdom. ${ }^{61}$

Finally, Quesnell notes that Matthew diverges from Luke significantly in the saying about marriage which occurs in the dispute about the resurrection (Luke 20:27-30; cf. Matt 22:23-33; Mark 12:18-27). Quesnell notes that Luke distinguishes two classes of men in relation to the kingdom, "And Jesus said to them, "The sons of this age marry and are given in marriage; but those who are accounted worthy to attain to that age and to the resurrection from the dead neither marry nor are given in marriage"' (Luke 20:34-35). Quesnell points to the verbs in Luke, present tense, but that Matthew (23:30), following Mark's lead (12:25), simply describes a future situation, "For in the resurrection they neither marry nor are given in marriage, but are like angels in heaven." Here again, in the Lukan account, men are not marrying, "those who are accounted worthy to attain to that age and to the resurrection from the dead neither marry nor are given in marriage" (Luke $20: 35) .^{62}$

Kelber supports Quesnell's contextual approach to the teaching on divorce where in the Kingdom of God the loss of consanguine connection is superseded by becoming a member of the Kingdom: "They [the disciples] do not possess houses or fields, and they have broken with father and mother"; that "in effect, Jesus gives an advance warning

${ }^{61}$ Ibid., 346; cf. D. L. Bach, "Background of 1 Cor VII: Sayings of the Lord in Q," NTS 18 (19711972): 351-364.

${ }^{62}$ Quesnell, "Eunuchs,” 345-349. 
against settling down, striking roots" in a kingdom in which divorcing for the sake of remarrying strikes at the root of the principles of that Kingdom. ${ }^{63}$

\section{The Jesus Seminar}

The Jesus Seminar took the task of designating by color coding in red "words that were most probably spoken by Jesus" in the Synoptic Gospels; in pink (as a weak form of red) "words ascribed to Jesus by his admirers or enemies" but not authentic. Bold black are the "inauthentic" words, and gray are those which did not originate with Jesus though they may reflect his ideas. ${ }^{64}$ Jesus' counter-question in Mark 10:3, for example, is set in bold black letters (inauthentic). The same can be said of the Matthean account ${ }^{65}$ where the "exception clause" is also in bold black; while the laconic Lukan statement (16:18) is set in gray. ${ }^{66}$

Since the Seminar did not assign red letters to any of the "divorce" accounts, it means that the Seminar members believe that none of the wording in the Synoptics were most probably spoken by Jesus. Most of the Markan sayings are set in gray, though originated with Jesus, but not necessarily spoken by him. So, according to the Seminar, this means that for Christian denominations to debate the legality or illegality of divorce

\footnotetext{
${ }^{63}$ Werner H. Kelber, The Kingdom in Mark (Philadelphia: Fortress, 1974), 90-91; cf. I. Howard Marshall and W. Ward Gasque, eds., The Gospel of Luke: A Commentary on the Greek Text, New International Greek Testament Commentary (Grand Rapids, MI: Eerdmans, 1978), 740-741.

${ }^{64}$ Robert W. Funk, Roy W. Hoover, and The Jesus Seminar, trans. and commentary, The Five Gospels: The Search for the Authentic Words of Jesus (New York: Macmillan, 1993), ix-x. For the Jesus Seminar's "coloring” of Mark 10:1-12, see ibid., 87-88.

${ }^{65}$ See ibid., 219.

${ }^{66}$ See ibid., 360.
} 
may be totally immaterial since we are uncertain as to what Jesus may have really taught on the question.

\section{The Question of Grammar}

Greek grammar has been brought into the fray. Young, for example, places the main thrust of the "divorce" sayings in his grammatical-syntactical analysis of the passage. Although the Lukan account (16:18) uses the indicative, Young hinges his interpretation of the "divorce" logion in the Markan (10:11) and Matthean (19:9) use of the subjunctive mood. Young notes that the subjunctive mood in Greek carries a sense of purpose, especially with a hina clause. And while Young admits that the hina clause is not present in either Mark or Matthew, he believes that both Mark and Matthew thought of the purpose when using the subjunctive. According to Young, this is how the text should be rendered: "Whoever divorces his wife in order [emphasis supplied] to marry another commits adultery against her." He posits:

The idea is that such divorced persons obtained the divorce in order to remarry. In Hebrew the force of the expression would have linked the two actions together in continuous motion: kol hasholeach et eshto venose acheret noef ("every one who divorces and marries another commits adultery"). The Torah does allow for divorce and remarriage, but divorce must not be used as convenience to consummate adultery. . . . However, one can obtain a divorce for the sake of remarriage and thereby break the sacred trust of marriage fidelity. It would seem, then, that Jesus did not abrogate the Hebrew Scriptures concerning marriage, divorce and remarriage. He did desire, however, to set limits to its application. When a man divorced his wife in order to marry another, such an action would preserve the letter of the law, but that action would violate the spirit of the law. When the legal system is used to abuse one partner of the marriage contract by seeking a new relationship, the meaning of the higher purpose of the law is nullified. No one should lessen the force of a powerful saying of Jesus. When a man abuses the law and divorces his wife in order to marry someone new, it is the same as adultery. ${ }^{67}$

\footnotetext{
${ }^{67}$ Brad H. Young, Jesus the Jewish Theologian (Peabody, MA: Hendrickson, 1995), 117. Cf. Bultmann who asserted that "originally it would be that the man was guilty if he divorced his wife in order
} 


\section{Background to the Problem}

Mark and Matthew have placed the "divorce" issue against the background of a

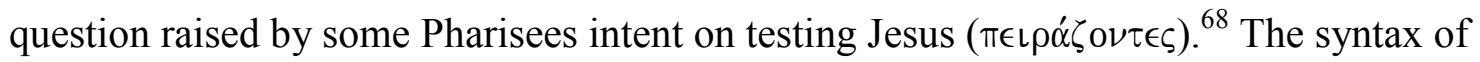
the "divorce" logia in the Synoptics in the Pharisaic question, ${ }^{69}$ and Jesus" directing them to Moses, seem to indicate that there may have been some sort of misapplication surrounding the Mosaic legislation on the question concerning divorce (Deut 24:1-3). ${ }^{70}$ They question whether it is "lawful for a man to 'divorce' his wife." According to the Markan account, as to the "lawfulness" of the practice, if in fact this is what they are asking, Jesus directs them to Moses (10:3). They respond by alluding to Deut 24:1,

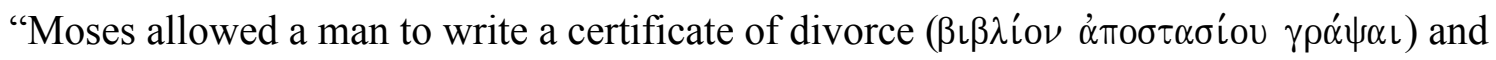

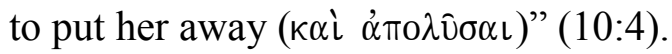

to marry another woman." History, 132. One question that may weaken the "hina clause" argument, however, is: Why would a man need to divorce his wife "in order to" marry another in a society that did not frown upon polygamy?

${ }^{68} \Pi \epsilon \iota \rho \alpha ́ \zeta 0 \nu \tau \epsilon \zeta$ is an adverbial, present, active participle and, when connected with $\epsilon \pi \eta \rho \omega ́ \tau \omega \nu$ ("asking or inquiring"), the imperfect indicates continued or repeated attempts to entrap Jesus. This continued or repeated testing of Jesus is accentuated in Mark where the Pharisees, at times in accord with the Herodians, progressively intensify their attempts to ensnare him. See Mark 2:6, 16, 18, 23-24; 3:1-2,

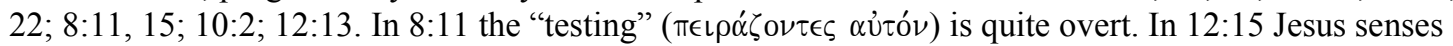
their intentions, "Why do you test me?" (Tí $\mu \epsilon \pi \epsilon \iota \alpha \dot{\zeta} \zeta \epsilon \tau \epsilon$;). It is interesting to note that Mark uses the same participle, albeit, in the passive voice ( $\pi \iota \rho \alpha \zeta$ ó $\mu \in \nu \circ \varsigma)$, in Satan's "testing" or "tempting" of Jesus in the desert (1:13).

${ }^{69}$ ' A $\pi 0 \lambda \cup$ ú is the verb translated "to divorce" in the Synoptic narratives. This verb is expressed five times as an anarthrous aorist infinitive: $\alpha \pi \operatorname{\alpha } \lambda \hat{v} \sigma \alpha \iota$ (Matt 19:3, 7, 8; Mark 10:2, 4). Syntactically, an aorist infinitive expresses purpose. If "divorce" is the correct translation of $\alpha \pi 0 \lambda u$ u, then the Pharisees are posing a legitimate question regarding a divorce situation brought to Jesus' attention through the main controversial question: "Is it lawful ( $\left.{ }^{\prime} \xi \epsilon \sigma \tau \iota \nu\right)$ for a man to divorce his wife?" Baltsenweiler considered the Pharisees' question as "factual” (Sachfragen). See Heinrich Baltensweiler, Die Ehe im Neuen Testament (Zurich, Switzerland: Zwingli Verlag, 1967), 35-39. German translations into English throughout this study are by courtesy of Martin Pröbstle.

${ }^{70}$ If "divorce," however, is not the correct translation, then something other than the Jewish understanding of the divorce practices looms in the background, thus making the Pharisaic question a "trick question" (Fangfragen). See Baltensweiler, Die Ehe, 35-39. 
By all accounts, that should have settled the question, but evidently, it did not, not even in the minds of the disciples (see Mark 10:10), which may hint at something deeper in the Pharisees' $\pi \epsilon \iota \alpha \dot{\zeta} \zeta \nu \tau \tau \epsilon$. In the Matthean account the “exception clause" implies that a marriage may be broken by divorce. In a literalistic reading of the Gospel of Mark, however, the absence of an "exception clause" gives the impression that divorce is not possible. $^{71}$

"Some Pharisees came, and to test him they asked, 'Is it lawful for a man to divorce his wife?" (Mark 10:2). ${ }^{72}$ Why would the Pharisees "test" Jesus over an issue in which Judaism was well versed ${ }^{73}$ Pharisees, the scribes of the Pharisees, the Sadducees, and the majority of practicing Jews were in agreement that divorce was allowed under the provisions of Deut 24. Whatever Moses wrote would be a matter of debate, but its authority was never questioned. Nineham has asserted that "in that precise form the question must have originated with St. Mark or at any rate with some group of Christians; for a Jew, not to say a Pharisee, would hardly have posed such a radical question; for him Deut 24:1-4 made clear beyond doubt that divorce is lawful in certain circumstances."74

\footnotetext{
${ }^{71}$ Down surmises that a literalistic reading of the Gospels is what produced a "sacramentalism that is nowhere to be found in Scripture." He posits that "the Jewish legacy of Christianity by which an individual was lost in an indissoluble mystic union and legal rights abolished a concept which in practice could work to the detriment of the wife, was a medieval invention, derived from a literalistic reading of the gospel material." Michael J. Down, "The Sayings of Jesus about Marriage and Divorce," Expository Times 95 (1984): 332-334.

${ }^{72}$ Matthew adds, "For any cause" (19:3).

${ }^{73} \mathrm{~A}$ few form critics have challenged the Sitz im Leben of the Pharisaic question or even that such a question was ever posed to Jesus. Turner, a textual critic, in an analysis of the Western text argues that

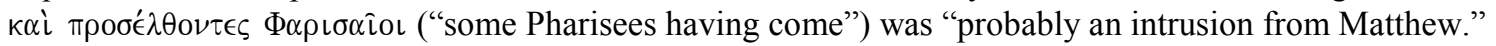
Cuthbert H. Turner, "Western Readings in the Second Half of St. Mark's Gospel," JTS 29 (1928): 5. For an expanded and more recent exposition of this position, see Paul Ellingworth, "Text and Context in Mark 10:2, 10," JSNT 5 (1979): 63-66.

${ }^{74}$ Dennis Nineham, The Gospel of Mark (New York: Seabury, 1963), 259-260.
} 
Collins states that "there is no evidence that any Jewish group in the first century CE forbade divorce," and that the question whether a man is permitted to divorce his wife is, culturally speaking, very odd.",75

In the Hillel-Shammai debates, for example, the question was never over the legality or illegality of divorce, but over the interpretation of the 'erwat davar (24:1). ${ }^{76}$ The Babylonian Talmud, perhaps reflecting the liberal attitude of the school of Hillel, states: "A bad wife is like leprosy to her husband. What is the remedy? Let him divorce her and be cured of his leprosy.",77 Historically, Judaism was clear that divorce was permissible. ${ }^{78}$ About a stubborn wife, Joshua ben Sirach (ca 200 BCE) advised: "If she go not as you would have her go, cut her off from your flesh, and give her a bill of divorce, and let her go" (Ecclus 25:26). And Josephus comments:

He that desires to be divorced from his wife for any cause whatsoever, and many such causes happen among men, let him in writing give assurance that he will never use her as his wife anymore; for by this means she may be at liberty to marry another husband, although before this bill of divorce be given, she is not permitted to do so. ${ }^{79}$

${ }^{75}$ A. Collins, Mark, 465.

${ }^{76}$ See m. Git. 9:10; and b. Git. 90a.

${ }^{77}$ b. Yebam. 63b. For an expanded view as to how Jewish rabbis adapted and expanded (not restricted) the teaching concerning divorce in post-NT times, see Instone-Brewer, "Rabbinic Teaching," 8590; also Isodore Epstein, ed., The Babylonian Talmud (London: Soncino Press, 1935-1948), 2:218-219; and the Jerusalem Talmud. Jacob Neusner, trans., The Talmud of the Land of Israel (Chicago: University of Chicago Press, 1982-1994), 13B:82, 95, 139, 164-165, 277.

${ }^{78}$ This concept extended to post-biblical Judaism, and, apparently, its existence was assumed in pre-Mosaic times. Targum Pseudo-Jonathan on Gen 21:14 portrays the widely held Jewish position on divorce. Abraham's dismissal of Hagar is described this way: "And he gave [bread and a skin of water] to Hagar to bear upon her shoulder and bound [a veil] [sic] to her loins, to signify that she was a servant, as also the child, and dismissed with a letter of divorce." John Wesley Etheridge, trans., The Targum of Onkelos and Jonathan ben Uzziel on the Pentateuch, (London: Longman, Green, Longman, Roberts, and Green, 1951), 1:224.

${ }^{79}$ Josephus, Jewish Antiquities, 4.8.23, in Flavius Josephus, The Works of Josephus: Complete and Unabridged, trans. William Whiston, rev. ed. (Peabody, MA: Hendrickson, 1988). 
As far as can be known, only one Jewish sect adopted an extreme position regarding divorce and remarriage: the sect of Qumran. The priestly order of this ascetic sect, the Zadokites, not only prohibited divorce but also remarriage, apparently, even after the death of a spouse. ${ }^{80}$ In actual practice, it appears that a man could legally dissolve his marriage in two ways: (1) Privately in the presence of two witnesses, ${ }^{81}$ or (2) through an accredited agent, generally a scribe. ${ }^{82}$

Some of the same Jewish sources, however, seem to suggest that divorce was not as prevalent as the Gospels would appear to insinuate. The Babylonian Talmud, for example, implies that divorce was not as widespread and that it was not readily acceptable by the rabbis. ${ }^{83}$ According to Rabbi Eleazar, "whoever divorces his first wife, even the altar sheds tears on her behalf; as it is said, 'and this again ye do; ye cover the altar of the Lord with tears . . because the Lord has been witness between thee and the wife of thy youth, against whom thou hast dealt treacherously"" (Mal 2:13-17). ${ }^{84} \mathrm{I}$. Abrahams states that

\footnotetext{
${ }^{80}$ See Cumram Documents (CD) 4.20-21. Florentino García Martínez, trans., The Dead Sea Scrolls Translated (San Francisco: HarperSanFrancisco, 1996), 35-36. G. Vermes, however, has insisted for some time that the passage argues against polygamy, not against divorce. See Geza Vermes, The Dead Sea Scrolls: Qumran in Perspective (Philadelphia: Fortress, 1977), 112-113; cf. G. Vermes, "Sectarian Matrimonial Halakhah in the Damascus Rule," JJS 25 (1974): 197-202. In some scholarly quarters there are those who connect Jesus to the Qumran community, whether as the Teacher of Righteousness or as one who based his teachings on their brand of interpretation, including his position on divorce and remarriage. See for example Jacob L. Teicher, “Jesus' Sayings in the Dead Sea Scrolls,” JJS 5 (1954): 38.

${ }^{81}$ It is unclear when this law was actually enacted. Nevertheless, it was originally intended for Jews living outside Israel who did not have access to a scribe as described in b. Git. 2a-5b and Ket. 6a-9b. Also, see m. Git. 8.9; Sanh. 7.3, 9 .

${ }^{82}$ See $m$. Ket. $3 ; 7 ; 13$, also b. Git. 2a-3b; cf. note 78 above.

${ }^{83}$ b. Sanh. 22a.

${ }^{84}$ b. Git. 90 a.
} 
Jewish sentiment was strongly opposed to the divorce of a wife of a man's youth. ... The facilities for divorce seem mostly to have applied or taken advantage of in the case of a widower's second marriage. "What the Lord hath joined together, let no man put asunder" represented the spirit of the Pharisaic practice in the age of Jesus, at all events with regard to a man's first marriage. ${ }^{85}$

If the understanding of the legal aspects of divorce in first-century Palestine is correct, divorce before a scribe as established by the rabbis, ${ }^{86}$ although legal, does not appear to be so prevalent, mainly because among other things there was a high price fixed in the marriage contract, ${ }^{87}$ and a stigma followed not only the wife and her daughters, but also the husband. ${ }^{88}$ The question is further complicated when one observes that:

1. The Synoptists do not agree with each other on the wording, vocabulary, and syntax when describing divorce and subsequent remarriage. ${ }^{89}$ And Paul, who received a "command" directly from the Lord (1 Cor 7:10), is not in agreement with the synoptic in wording, vocabulary, and syntax..$^{90}$

2. Modern Bible translations create stumbling blocks for the student who studies the Bible in a language other than the original one. The inconsistency in which particular

${ }^{85}$ Israel Abrahams, Studies in Pharisaism and the Gospels (New York: Ktav, 1967), 68.

${ }^{86}$ b. Git.17a-24b.

${ }^{87}$ See Jeremias, Jerusalem, 370-371.

${ }^{88}$ m. Ned. 9.9 .

${ }^{89}$ A discussion of the "Synoptic Problem" is beyond the scope of this study. For a consideration of this topic, see R. A. Derrenbacker, Ancient Compositional Practices and the Synoptic Problem (Dudley, MA: Peeters, 2005); cf. H. W. Shin, Textual Criticism and the Synoptic Problem: The Search for Valid Criteria (Dudley, MA: Peeters, 2004); David Alan Black and David R. Beck, eds., Rethinking the Synoptic Problem (Grand Rapids, MI: Baker Academic, 2001), 22-24; and Mark S. Goodacre, The Synoptic Problem: A Way Through the Maze (London: Sheffield Academic Press, 2001).

${ }^{90}$ See David Instone-Brewer, "Divorce Papyri 1," 101-115; and his "1 Corinthians 7 in the Light of the Jewish, Greek, and Aramaic Marriage and Divorce Papyri," TynBul 52, no. 2 (2001): 225-243; Jerome Murphy-O’Connor, 1 Corinthians (New York: Doubleday, 1998); England, "Divorce and Remarriage." 
words are translated ${ }^{91}$ causes students of modern Bible translations to take the words of Jesus literally, as ideals, or figures of speech. ${ }^{92}$

3. Historically the Church has tended to conflate all the sayings of Jesus as if they all belonged to one setting and one audience, or by placing the sayings of Jesus in legal terms. ${ }^{93}$

The twentieth century saw a deluge of opinions concerning the "divorce" sayings in the Gospels. Midway through the century Robinson found fault with a myriad of methodological assumptions for "which Mark is silent" or not explicit in Mark. ${ }^{94}$ Robinson wrote when half the things had not been written regarding the divorce interpretation of the Gospels. Martin rightly observes that "the key to the elucidation of the gospel is not to be found in some hidden secret known only to the evangelist ... [nor] is it a book belonging to the genre of apocalyptic mysticism. ... It does not lie in the solving of a conundrum . . . of scattered hints . . brilliant but unachieved to read into Mark what is not there." 95

\footnotetext{
${ }^{91}$ Fee has correctly observed that "whenever translations have truly significant differences between/among them, this is a sure indication that some exegetical difficulty lies behind the differences." Gordon D. Fee, New Testament Exegesis: A Handbook for Students and Pastors, $3^{\text {rd }}$ ed. (Louisville, KY: Westminster John Knox, 2002), 12.

${ }^{92}$ For a discussion of the different ways in which the sayings of Jesus are generally interpreted, see Robert H. Stein, Difficult Sayings in the Gospels: Jesus' Use of Overstatement and Hyperbole (Grand Rapids, MI: Baker, 1985), 19-97; cf. with Stein, The Method and Message of Jesus Teaching (Philadelphia: Westminster, 1978), 7-33.

${ }^{93}$ Bartling, though commenting on Paul, has correctly noted that "Christ is torn out of his kerygmatic context and contorted into law," and chides the Church for turning the sayings of Jesus into legal questions because "a code is more comfortable to live with." Bartling, "Sexuality," 364.

${ }^{94}$ James M. Robinson, The Problem of History in Mark (Naperville, IL: Allenson, 1957), 12.

${ }^{95}$ Martin, Mark, 91.
} 
Based on these observations, fundamental questions emerge: What did Mark want to teach about Jesus' teaching on "divorce," and what did Mark's audience understand? To these basic questions, corollary questions arise: If Mark was written for a Gentile audience, was Mark successful in his "transcultural" interpretation of Jesus' teaching on "divorce" from a Jewish setting to a seemingly Gentile audience and worldview? Did the Markan Jesus introduce the Gentile practice of "divorce” (10:12) ${ }^{96}$ or was it Mark interpreting Jesus' teaching to fit his assumed Gentile audience in Rome (or Palestine) $?^{97}$ What are we to make of the apparent contradiction between witnesses to Jewish divorce in the Synoptic accounts and the rabbinic literature? Should a logion written in a Gentile context (Mark) be approached in the same way as a logion written in a Jewish context (Matthew)? ${ }^{98}$ What was Jesus reacting to which prompted him to make statements in private to the disciples (Mark 10:10) which he apparently dare not make in public? How

\footnotetext{
${ }^{96}$ It is a generally held view that Mark wrote for a Gentile audience outside of Palestine. For bibliographic information on this view, see Raymond F. Collins, Sexual Ethics in the New Testament: Behavior and Belief (New York: Crossroad, 2000), 25-26; Moloney, Mark, 196; Healy, Mark, 198; Boring, Mark, 287; Witherington, Mark, 278; K. Stock, Marco, 199; Standaert, Marc, 729; Martin, Mark, 221; cf. Berger, who also distinguishes Mark 10:10-12 as being a later addition to the original pericope, and considers Mark 10:9 more historical than 10:2-8. Klaus Berger, Die gesetzesauslegung Jesu (NeukirchenVluyn: Neukirchener, 1972), 576; and Schweizer, Good News, 201-202. A literary structural analysis appears to support the position of some of the earlier commentators such as Henry Barclay Swete, The Gospel according to St. Mark: The Greek Text with Introduction, Notes and Indices, $3^{\text {rd }}$ ed., reprint (Grand Rapids, MI: Eerdmans, 1951), 218, and Gustav Wohlenberg, Des evangelium des Markus (Leipzig: A Deickert, 1910), 197, in which the disciples' question "in the house," is part of the original pericope. See my structural analysis in chapter 4.

${ }^{97}$ For a documented explanation of the probability of Mark's Gentile audience in Palestine, see Kelly R. Iverson, Gentiles in the Gospel of Mark, Library of New Testament Studies 339 (New York: T \& T Clark, 2007), 1-3, 83-87; cf. Lyle Dale Vander Broek, “The Markan 'Sitz im Leben': A Critical Investigation into the Possibility of a Palestinian Setting for the Gospel” (Ph.D. diss., Drew University, 1983); and Alfred Wikenhauser, New Testament Introduction (New York: Herder \& Herder, 1958), 155173.

${ }^{98}$ It is the general assumption that the Matthean account was rendered in a Jewish milieu. See Donald Guthrie, New Testament Introduction, 4th ed. (Downers Grove, IL: InterVarsity, 1990), 38-39, 4345.
} 
do Mark's textual differences in relation to Matthew affect the intended purpose of each logion? What do we do with the differences? How should a logion written to a Gentile audience (Mark's) be interpreted in light of the fact that it was originally uttered in a Jewish context? ${ }^{99}$

Was there an intentional "de-judaizing” of Jesus' "divorce” saying on Mark's part, or was it Matthew who "judaized" the Lord's teaching for his intended audience? ${ }^{100}$ Can Mark's account be interpreted in light of the Sitz im Leben Jesu? What about Mark's Sitz im Leben? Was the Pharisaic question "Sachfragen" or "Fangfragen?"101

\section{Statement of the Problem}

The above questions have not been addressed satisfactorily when studying the "divorce" saying in the Markan Gospel. And although Mark has something significant to say on his own, no major study has specifically focused on the "divorce" logion as it appears in Mark.

\section{Statement of Purpose}

The purpose of this dissertation is to examine the dominical response on "divorce" as recorded in the Gospel of Mark:

1. Find the delimitation of the Markan pericope on "divorce."

2. Do a literary and structural analysis of the pericope.

${ }^{99}$ Considerations of the Markan setting are presented in chapter 2.

${ }^{100}$ Although this study is written under the assumption of a Markan priority, no attempt will be made to defend it for the conclusions reached in the exegesis chapter. For more on the priority of Mark, see Peter M. Head, Christology and the Synoptic Problem: An Argument for Markan Priority (New York: Cambridge University Press, 1997).

${ }^{101}$ A factual or a trick question. See Baltensweiler, Die Ehe, 36. 
3. Do an intertextual analysis of key words, phrases, and textual differences.

4. Analyze the wording used and/or translated as "divorce."

5. Investigate the purpose and background of the Pharisees' question/intention.

6. Investigate the probable provenance of the Markan account.

7. Research the divorce practices in the Greco-Roman world in the first century

$\mathrm{BCE}$ to the first century $\mathrm{CE}$ in order to see how those practices may have affected the Gentile divorce practices that Mark attempted to address.

\section{Justification for the Study}

Why study Mark's account? Historically, Mark has been the neglected Gospel when it comes to the study of the divorce and remarriage question. The Christian interpretation and application of the questions of divorce and remarriage have been overwhelmingly influenced by the Matthean account. The audience of each evangelist, however, seems to be different. Since the intended audience of Mark is widely believed to have been a Gentile one, the textual differences in each evangelist appear to be intentional, rather than accidental. ${ }^{102}$ To Mark's Gentile audience, for example, the HillelShammai controversy (or any other rabbinic polemic that may be alluded to in Matthew) was most probably unimportant and perhaps even meaningless. ${ }^{103}$

\footnotetext{
102،"It is now generally recognized that the evangelists were not merely 'scissors and paste men.' On the contrary, the 'scissors' were manipulated by a theological hand and the 'paste' was impregnated with a particular theology." Robert H. Stein, Gospels and Tradition: A Study on Redaction Criticism of the Synoptic Gospels (Grand Rapids, MI: Baker, 1991), 22. The first scholars to make a strong argument in this direction in the mid-1950s and working independently from one another were Hans Conzelmann, The Theology of St. Luke, trans. Geoffrey Buswell (New York: Harper, 1960) and Willi Marxsen, Mark the Evangelist (New York: Abingdon, 1969).

${ }^{103}$ Even in first-century Palestine, the great majority of the Jewish people, referred to as the am haaretz, "the people of the land," were generally non-practicing Jews. The title was originally used for nonJews in Palestine (see Neh 10:28) later to include non-practicing Jews; see Gerd Theissen, Sociology of
} 
The following factors elicit a need for a dissertation on Jesus' saying on divorce in the Gospel of Mark:

1. In spite of the abundance of material on the subject, no major study has analyzed Mark's saying on divorce as an independent Gospel. ${ }^{104}$

2. The Church's interpretation of "divorce" passages has generally ignored Mark's particular audience, namely, a Gentile one.

3. Most commentators on the "divorce" saying of Jesus in Mark have generally interpreted it as a categorical statement barring divorce altogether (unlike Matthew who contains an exception).

\section{Assumptions}

The Synoptic writers do not appear to have envisioned a denominationalism in which the teaching of Jesus on "divorce" would be systematized and/or dogmatized; Mark and Matthew simply picked up on the "divorce" saying which Jesus most probably

Early Palestinian Christianity, trans. John Bowden (Philadelphia: Fortress, 1977), 85. Sanders disclaims that this title was used to refer to sinners in the Gospels. See Ed Parish Sanders, "Jesus and Sinners," JSNT 19 (1983): 5-36. In truth, Torah-keeping Jews appear to have been in the minority. The Pharisees numbered around 6,000 (see Josephus, Antiquities, 17.42-41), the Sadducees in the hundreds. The Qumran sect kept to itself. The militant sects, who attracted large numbers, became less interested in theological debates and more in liberating the land from Roman oppression. Would the small number of "God-fearing" Gentiles show some interest in such debates? It is hard to say. Now, if scholars are correct that the Gospel of Mark originated outside Palestine, it begs the question, Would Gentiles care about Jewish religious debates in a far-away land? For more on the religious Jewish practices and other Jewish sects, see David Flusser, Judaism of the Second Temple Period, trans. Azzan Yadin (Grand Rapids, MI: Eerdmans, 2007), 77-79; cf. Jacob Neusner and William Scott Green, eds., The Pharisees and Other Sects (New York: Garland, 1990), 2:119-221; Safrai, Jewish People, 1:213-231, and Simon Marcel, Jewish Sects at the Time of Jesus (Philadelphia: Fortress, 1967), 75-81, 112-131, 201-217.

${ }^{104}$ Some studies have attempted to analyze the Synoptic pericopes independently but usually end up with a systematic application as they seek to relate the different accounts. This is generally due to the lack of consideration of the redactional purposes of each evangelist. Riggs expresses the general sentiment: "As Matthew 19 and Mark 10 captured the same event in distinct ways ... some major differences appear when one examines these passages, but one relinquishes his responsibilities too soon if he does not explore ways to harmonize the two." Riggs, Rhetorical-Critical Interpretation, 239. 
uttered in a Palestinian setting. ${ }^{105}$ And because it is widely considered that both Matthew and Mark were bona fide theologians writing to specific audiences, ${ }^{106}$ whether Mark's Gospel was written before or after Matthew is inconsequential to this study. ${ }^{107}$

Since the "divorce" saying in the Gospel of Mark is our intended subject, this study has been done under the general assumption that Mark wrote to Gentiles, accounting for the textual differences and uniqueness of Mark in relation to Matthew.

\section{Scope and Delimitations}

Although Matthew, Mark, and Luke are alike to the point of validating the term "Synoptic," not everything within them can be "seen together." Even though there are other surviving witnesses to the divorce logia beyond the Gospels (Paul), this dissertation focuses primarily on the divorce logion of the Gospel of Mark. Matthew's logion will be inter-textually considered in relation to Mark, where textual differences come into play. ${ }^{108}$ No attempt has been made to reconstruct the ipsissima verba Jesu, ${ }^{109}$ rather, the logion will be studied as it is found in the surviving testimony of Mark.

${ }^{105}$ See Vander Broek, "Sitz im Leben," 45-47.

${ }^{106}$ See note 102 above.

${ }^{107}$ A large segment of NT scholarship subscribes to the notion that Mark's account is the most original and meets the most criteria for authenticity. For a detailed account and bibliographic references, see Soulen, "Marriage and Divorce," 439-450. Catchpole phrased it well when he says that "while there is widespread agreement that the Gospel traditions cannot be merged, there is considerable confusion and disagreement about which traditions (if any) provide the best means of access to the mind of Jesus." Catchpole, "Synoptic Divorce," 92.

${ }^{108}$ As to the Lukan account, Marshall noted, "It is difficult to trace back the various sections [of Luke 16] to their original situation and purpose in the teaching of Jesus.” Marshall, Luke, 74. Luke's succinct statement is accounted for in Matt 5:32 and 19:9.

${ }^{109}$ Contrary to popular opinion, the red lettering in many of our modern Bibles does not represent the ipsissima vox Jesu. And unless one could discover the Aramaic texts of the Gospels, the language in which Jesus purportedly taught, such attempt seems futile; see N. Perrin, Rediscovering the Teaching of Jesus (New York: Harper \& Row, 1967), 15-17. The sheer amount of variants in the extant MSS should be 


\section{Methodology}

Very early in exegetical studies, a student's consciousness is hammered with the fact that in studying any biblical text, it is most important to study first what the text meant (the "then") to the original hearers before he/she is able to interpret what the text may mean today (the "now"). ${ }^{110}$ It is on this premise that the Markan logion on "divorce" (and remarriage) has been approached. Witherington's statement is very apropos as one begins to investigate this issue: "There is a danger when dealing with a crux interpretation of assuming that because old solutions do not appear satisfactory, then a new view is more likely to be true than the standard interpretation." Witherington cautions that "one must be wary, however, of replacing an unsatisfactory old view with an equally unsatisfactory new one," and that a search for another view should not be discouraged simply because "one can find a view that satisfies the usual objections to the traditional view without resorting to exegetical gymnastics, then it is certainly worth close scrutiny.",111

Because the Synoptic Gospels, universally considered a different genre from the rest of the New Testament, went through a process of selection, arrangement, and adaptation, ${ }^{112}$ the analysis of individual pericopes is required in Synoptic studies. The

enough to convince us of this; see Reuben Swanson, ed., New Testament Greek Manuscripts: Matthew to Acts (Sheffield, UK: Sheffield Academic Press, 1995); for as Koester has noted, "The gospel literature before canonization was a literature that was subject to numerous revisions and rewritings." H. Koester, "History and Development of Mark's Gospel," Colloquy on NT Studies, ed. Bruce Corley (Macon, GA: Mercer University Press, 1983), 62-63.

${ }^{110}$ It would be impractical to review the vast array of interpretations that have come from the Church throughout the centuries. For a full bibliographic reference, see p.4, n.4 and p.5, n.6.

${ }^{111}$ Witherington, “Exception or Exceptional?” 571.

${ }^{112}$ For a view on a literary formation of the text, see D. A. Carson, Collected Writings of Scripture, comp. Andrew David Naselli (Wheaton, IL: Crossway Books, 2010), section I; Edgar V. McKnight, Jesus Christ Today: The Historical Shaping of Jesus for the Twenty-First Century (Macon, GA; Mercer 
logion under study places the account in the context of a Pharisaic-Herodian plot to trap Jesus and carry him to a fate similar to that of John the Baptist, who criticized Herod for taking Herodias, his brother's wife. ${ }^{113}$ When one considers the Sitz im Leben in which the events took place, and the audience to whom the evangelist directed this particular logion, it becomes compelling to attend to fundamental exegetical considerations within the pericope.

This analysis raises questions such as: What sort of historical background precipitated the Pharisaic question? What did Mark understand from Jesus' response to the Pharisees and how did he interpret that which he understood Jesus had said? What did Mark intend his hearers to understand, and what did his hearers understand in the context in which it was said? Who were his hearers/readers and where were they residing?

In trying to answer these and other questions, special emphasis will be placed on how Mark intended Jesus' teaching on "divorce," a Jewish teaching, to be understood in a Gentile context. In order to accomplish this, we will consider a twofold approach: (1) analyzing the Gentile presence and influence in Palestine, specifically in Galilee, during the first century CE, and (2) analyzing the divorce situation under Greco-Roman law and its possible influence in Palestine.

University Press, 2009); David L. Dungan, A History of the Synoptic Problem: The Canon, the Context, the Composition, and the Interpretation of the Gospels, ABRL, ed. David N. Freedman (New York: Doubleday, 1999); Warren S. Kissinger, The Lives of Jesus: History and Bibliography (New York: Garland, 1985); Étienne Trocmé, The Formation of the Gospel according to Mark, trans. Pamela Gaughan (Philadelphia: Westminster, 1975), 1-86. For a synthesis pro and con of Tradition Criticism, which embraces source, form, redaction, and historical criticism, see Darrell L. Bock, "Redaction Criticism," in Interpreting the New Testament: Essays on Methods and Issues, ed. David Allan Black and David S. Dockery (Nashville: Broadman and Holman, 2001), 105-133; Stein, Gospels and Tradition; Scot McKnight, Interpreting the Synoptic Gospels (Grand Rapids, MI: Baker, 1988), 57-95. For a detailed explanation of such a process, see Wikenhauser, Introduction, 223-254.

${ }^{113}$ Against Bultmann who argues that the saying of Jesus on divorce in Mark is an "artificial construction" on the basis that it begins "with a question without any reference to any act", History, 26-27. 
In order to accomplish these objectives, the following procedure will be used:

1. Translate and analyze the grammar and syntax of the Markan pericope in order to clarify any special nuance the text may elucidate.

2. Study the contextual use of $\pi \in \iota \rho \alpha ́ \zeta o \nu \tau \epsilon \varsigma$ in Mark in order to understand the larger picture of the plot against Jesus which elucidated the dominical response.

3. Consider the role of the consecutive conjunction kai of the legal divorce

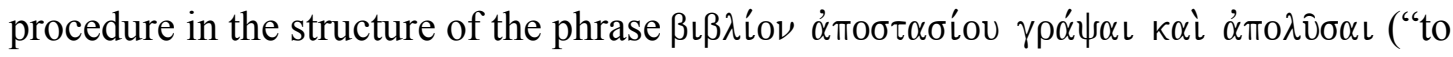

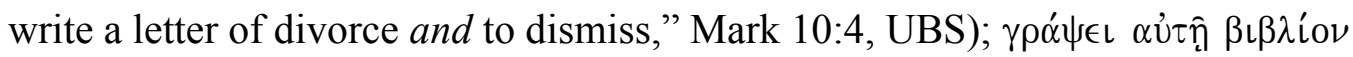

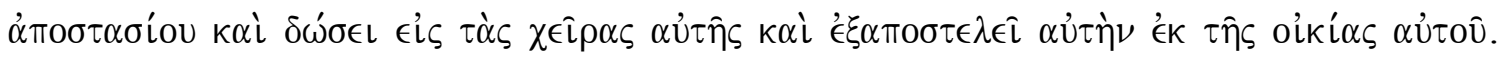
("he writes her a certificate of divorce, puts it in her hand, and sends her out of his house; she then leaves his house," Deut 24:1, LXX). ${ }^{114}$

4. Consider the interpretation of Deut 24:1-4 in the rabbinic literature, the writings of the Intertestamental period, and other classical literature of the period in order to understand what possible differences of interpretation may lurk between Jesus and the Pharisees that causes them to pose the provocative question, "Is it lawful for a man to divorce his wife?" (Mark 10:2).

5. Study the divorce practices of Greco-Roman society in the first century in and outside Palestine in order to elucidate the so-called "Roman influence" in Mark 10:12: "and if she divorces her husband and marries another, she commits adultery" (10:12).

6. Summarize and draw conclusions.

\footnotetext{
${ }^{114}$ Both Greek structures (of Mark 10:4 in the UBS and Deut 24:1 in the LXX) appear to emphasize the role of the consecutive conjunction kai of the legal divorce procedure: "Write a letter of divorce, put it in her hand, and [then] send her away." The implication is that by sending her away $(\dot{\alpha} \pi \mathrm{\lambda} \lambda \hat{\mathrm{v} \sigma \alpha \iota})$ without the letter of divorce, a divorce proper has not taken place.
} 


\section{CHAPTER 2}

\section{THE GALILEAN-GENTILE AUDIENCE OF MARK}

\section{Introduction}

The great majority of NT scholars assume that Palestinian material underlies much of the content of Mark's teaching, but that the Gospel itself was written to GentileChristians outside Palestine, namely, Rome. ${ }^{1}$ This assumption is based, among other things, on Mark's numerous Latinisms, his translation of Aramaic terms, and his explanation of Jewish practices. Mark does this, it is believed, in order to make his Gospel understandable to his Gentile, non-Palestinian audience. This study aims to ascertain whether there are any tell-tale signs, internally and/or externally, that may point to Mark's having a Gentile audience within Palestine, and as to whether the so-called "addendum" to the Markan "divorce" pericope (Mark 10:10-12) can be understood within this Galilean-Gentile community from where the Pharisaic controversy arose and

\footnotetext{
${ }^{1}$ The Gentile-Roman audience of the Gospel of Mark has been proposed and defended, among many others, by Standaert, Marc, 728; Stein, Mark, 458; R. F. Collins, Sexual Ethics, 25-26; John R. Donahue, "Windows and Mirrors: The Setting of Mark's Gospel," CBQ 57 (1995): 1-26; Robert A. Guelich, Mark 1-8:26, Word Biblical Commentary 34A (Dallas, TX: Word, 1989), xxix-xxxi; Martin Hengel, Studies in the Gospel of Mark (Philadelphia: Fortress, 1985), 1-30; Ernest Best, Following Jesus: Discipleship in the Gospel of Mark (Sheffield: University of Sheffield, 1981), 100-101; Guthrie, Introduction, 22-24; Hugh Anderson, The Gospel of Mark, NCB (London: Oliphants, 1976), 43; Martin, Mark, 72; Lane, Mark, 7-11; Hans Conzelmann, An Outline of the Theology of the New Testament, trans. John Bowden (New York: Harper \& Row, 1969), 121, 143-144; Joachim Rohde, Rediscovering the Teaching of the Evangelists, New Testament Library, trans. Dorothea M. Barton (London: SCM Press, 1968), 62-77; Vincent Taylor, The Gospel according to St. Mark (London: Macmillan, 1952), 26-29; Charles E. B. Cranfield, The Gospel according to St. Mark, CGTC (Cambridge: Cambridge University Press, 1950), 3-5.
} 
whose community, both Gentile and Jewish, was able to put in context the Lord's teaching on the question.

\section{The Gentile-Roman Audience of Mark}

B. W. Bacon's arguments of Mark's Roman audience, proposed early in the twentieth century, have been widely repeated, but not superseded. Bacon argued that no document would have survived had it been written by an "obscure" follower of Jesus in a place other than Rome, and that Matthew's and Luke's use of the Gospel shows that "the gospel had already attained wide currency and acceptation $[$ sic $]$," and to associate the Gospel with Peter would not have been enough for it to gain prominence unless an important community was behind it. ${ }^{2}$ Cook has added that "no Gospel having such small pretensions to apostolicity could have won in Palestine the place which Mark came to occupy."3

Defenders of Mark's Roman audience have mostly relied on Bacon's views.

Among those who have supported a Roman origin is Schweizer who echoed that the

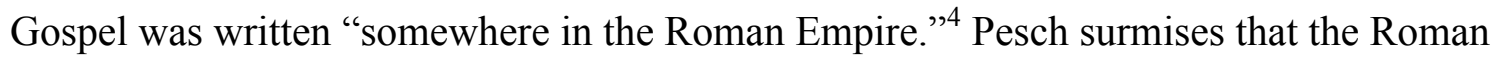
Christian community maintained closed ties to the primitive church of Palestine. ${ }^{5}$ Wilde places the Gospel in a Roman milieu in which the main theme is "self-preservation" and

\footnotetext{
${ }^{2}$ Benjamin W. Bacon, Is Mark a Roman Gospel? (Cambridge: Harvard University Press, 1919), 34, 38. For a more complete analysis, see Michael J. Cook, Mark's Treatment of the Jewish Leaders, Supplement to Novum Testamentum 51 (Leiden: Brill, 1978), 11-13.

${ }^{3}$ Cook, Mark's Treatment, 42-43. But, wouldn't this preclude the survival of other NT documents written outside of Rome? Aren't there other "obscure" NT writers (Jude?) whose books became part of the NT canon?

${ }^{4}$ Schweizer, Good News, 25. Was not Palestine part of the empire?

${ }^{5}$ Rudolf Pesch, Das Markusevangelium, Herders theologischer kommentar zum neuen testament (Freiburg: Herder, 1977), 1:14.
} 
where Roman officials are disassociated from the activities surrounding Jesus'

crucifixion. ${ }^{6}$ It has also been pointed out that incontestable signs in the Gospel suggest an origin outside Palestine. Among them:

1. Mark's attempt to translate the various Aramaic words into the Greek language or to explain their meaning (Mark $3: 17 ; 5: 41 ; 7: 11,34 ; 10: 46 ; 14: 36$ )

2. Mark's explanation of Jewish practices (Mark 14:12; 15:42)

3. Mark's limited number of citations from the OT (eighteen and mostly from the LXX)

4. The numerous use of Latinisms (Mark 4:21; 5:9, 15; 6:27, 37; 7:4; 12:14-15, $42 ; 15: 15,39)^{7}$

Cook defends a Roman provenance by appealing to the Gospel's translation of Aramaic terms since Mark "consists largely, perhaps almost exclusively, of Aramaic documentary material preserved in the archives of the church in Rome ... carried everywhere from Palestine by primitive evangelists," and that the book of Acts does not mention Galilee as the center where Mark was written. ${ }^{8}$ The notion, however, that the Gospel was written in Latin $^{9}$ has been summarily dismissed. ${ }^{10}$

\footnotetext{
${ }^{6}$ James Alan Wilde, "A Social Description of the Community Reflected in the Gospel of Mark" (Ph.D. diss., Drew University, 1983), 167-189.

${ }^{7}$ See Joseph Kudasiewics, The Synoptic Gospels Today, trans. Sergius Wroblewski (New York: Alba House, 1996), 109-110. For a complete list of Mark's use of Latinisms, see Paul Feine and Johannes Behm, Introduction to the New Testament, 14th rev. ed., ed. Werner G. Kümmel, trans. A. J. Matill, Jr. (Nashville: Abingdon, 1966), 64.

${ }^{8}$ Cook, Mark's Treatment, 49 . We do not know that Acts mentions the places where any of the NT books were written. As to the preservation of "archives of the church in Rome ... carried everywhere from Palestine by primitive evangelists," this appears to be an assumption from silence.

${ }^{9}$ Paul Louis Cochoud, Le mystère de Jésus (Paris: F. Rieder, 1924), 35-39.
} 
The main witness for a Roman audience of Mark appears to rely on the testimony of Papias. An appeal to this tradition, however, may not prove to be the strongest argument against an audience outside of Rome. Scholars who support a Roman audience based mainly on this ancient testimony seem to overlook that the Papias' testimony may indicate that he wanted to prove the authenticity of the Gospel by associating it with Peter. "The apologetic nature of Papias' words," says A. F. Walls, "was to defend the gospel against those who defended uncanonical gospels," ${ }^{11}$ or as R. P. Martin proposes, "Papias was defending the gospel against purported proponents of other Petrine documents," and that his only purpose was "to describe the evangelist's way of writing." 12 Martin, himself a Roman proponent, has conceded that "Papias' testimony is not free from tendenz." ${ }^{13}$ When these and other testimonies are factored in, it is not difficult to see why the Papias' testimony is questioned by a number of scholars. ${ }^{14}$ It is not without reason that Willi Marxsen refers to Papias' testimony as "historically worthless."15

\footnotetext{
${ }^{10}$ Marie Joseph Lagrange, “L’Évangile de Saint Marc n'a pas été écrit en Latin,” Revue Biblique 37 (1928): 114.

${ }^{11}$ Andrew F. Walls, "Papias and Oral Tradition," Vigiliae Christianae 21 (1967): 139.

${ }^{12}$ Martin, Mark, 83; cf. Horace Abram Rigg, Jr., "Papias on Mark," NovT 1 (1956): 181. For an expanded view on Papias' apologetic nature, see Vander Broek, "Sitz im Leben," 14-15.

${ }^{13}$ See Martin, Mark, 80 .

${ }^{14}$ See Roskam, Mark, 94-95. For an analysis and bibliography concerning the contradicting nature of Papias and other Patristic statements, see Vander Broek, "Sitz im Leben," 13-15.

${ }^{15}$ Willi Marxsen, Introduction to the New Testament, trans. G. Buswell (Philadelphia: Fortress, 1968), 143.
} 


\section{Mark's Other Non-Palestinian and Non-Roman Audience}

Though with much less acceptance, there are important centers which have been suggested as possible communities for whom Mark wrote his Gospel. Antioch of Syria, a primitive Christian center and launching pad for the proclamation of the gospel to Gentiles, was proposed early in the twentieth century by W. C. Allen. Allen considered that Mark wrote his Gospel in Jerusalem in Aramaic and that he later translated it into Greek while in Antioch. ${ }^{16}$ Allen's lead was soon followed by Bartlet who argued for Peter's connection with the Antiochene church, a center of Greco-Roman culture. Allen offered that Mark's acquaintance with Peter in Antioch provided the Syrian setting for the second Gospel. ${ }^{17}$ This view, cited more as an antiquated curiosity for almost fifty years, was revived in 1961. Suddenly, the Syrian setting aroused the attention of some NT scholars. Karnetzki created a case for a Gentile-Syrian audience. ${ }^{18}$ Soon after, Fuller, who called Mark "Hellenistic" for its language and tradition, also suggested an Antiochian audience. ${ }^{19}$ Following in Fuller's heels, Kee found the Palestinian setting of Mark's Gospel not to be “inconceivable," yet finding the Syrian setting to be quite

\footnotetext{
${ }^{16}$ See W. C. Allen, The Gospel according to St. Mark (London: George Bell, 1915), 6.

${ }^{17}$ James Vernon Bartlet, St. Mark: An Introduction, NCB 19 (New York: H. Frowde, 1925), 34-37.

${ }^{18}$ Manfred Karnetzki, “Die galiläische redaktion im markusevangelium,” $Z N W 52$ (1961): 246247.

${ }^{19}$ Reginald Horace Fuller, A Critical Introduction to the New Testament (London: G. Duckworth, 1966), 107.
} 
possible. ${ }^{20}$ And just as suddenly as it reappeared, the Syrian setting of Mark seems to have gone dormant for lack of a wider support. ${ }^{21}$

An Egyptian provenance was also suggested early in the twentieth century by Swete, ${ }^{22}$ followed by others, ${ }^{23}$ who seem to have built their case on a misunderstood quotation in the writings of Eusebius. ${ }^{24}$ This view won few followers mainly because it contradicted the most common statements of Papias, statements that gave support to the widely held Roman audience.

\section{Mark's Palestinian Audience}

To the prevalent view of a Roman audience of Mark's Gospel, important studies that began early in the twentieth century, yet taking momentum in recent years, appear to suggest that this may not have been the case. ${ }^{25}$ These studies propose that Palestine, north

\footnotetext{
${ }^{20}$ See Howard C. Kee, Community of the New Age: Studies in Mark's Gospel (Philadelphia: Westminster, 1977), 100-105.

${ }^{21}$ Joel Marcus made a passing mention in 1992 in "The Jewish War and the Sitz im Leben of Mark," Journal of Biblical Literature (JBL) 111 (1992): 460, and again in Marcus, Mark 1-8: A New Translation with Introduction and Commentary (New York: Doubleday, 2000), 33-37.

${ }^{22}$ See Swete, St. Mark, xviii-xx.

${ }^{23}$ See Thomas W. Manson, Studies in the Gospels (Manchester: Manchester University Press, 1962), 38-41; cf. S. E. Johnson, A Commentary on the Gospel according to Mark (New York: Harper, 1960), 34-35.

${ }^{24}$ Eusebius, in his Historia Ecclesiastica 2.16.1, stated: "They say that Mark set out for Egypt and was first to preach there the gospel which he had composed." Paul L. Maier, trans., Eusebius: The Church History (Grand Rapids, MI: Kregel, 1999), 73.

${ }^{25}$ For the most recent assessment of the extent of Gentile influences in Galilee, see Iverson, Gentiles, 20-176; cf. Roskam, Mark, 94-99; William R. Telford, Mark (London: T \& T Clark, 2003), 2425; William R. Telford, The Theology of the Gospel of Mark (New York: Cambridge University Press, 1999), 14-15; Vander Broek, "Sitz im Leben," 1983; Theodore J. Weeden, Sr., Mark: Traditions in Conflict (Philadelphia: Fortress, 1979), 70-71; Kelber, Kingdom, 65-66; Ernest Lohmeyer, Das evangelium des Markus (Göttingen: Vandenhoeck \& Ruperecht, 1963), 160-162; Robert H. Lightfoot, Locality and Doctrine in the Gospels (New York: Harper and Brother, 1938), 111-112; E. Lohmeyer, Galiläa und Jerusalem (Göttingen: Vandenhoeck \& Ruperecht, 1936), 28-29.
} 
to south and east to west, and bordering non-Palestinian towns, contained large numbers of Gentiles known since before NT times. ${ }^{26}$ They seem to have resided there since the time of the prophet Isaiah (9:1), who calls the region "Galilee of the Gentiles," a text quoted in Matt 4:15 (see 1 Mac 5:15).

Although a considerable number of NT scholars have contended against Mark's Palestinian audience with arguments which, by all appearances, should disqualify Palestine as a site for the setting of the Gospel of Mark, ${ }^{27}$ internal and external evidence gives us reasons to believe that the arguments for a Roman provenance (such as Mark's use of Latinisms and his translation of Aramaic words into Greek) may be explained in a Palestinian milieu. $^{28}$

\section{Hellenistic Influences in Galilee}

That Gentile, especially Greco-Roman, influence had been for many decades part of Palestinian life is a historical fact that few would now dare deny. ${ }^{29}$ Kee, who appears not totally persuaded in favor of a Palestinian setting of Mark's Gospel, nevertheless asserts: "Although the traditional locale, Rome, is chronologically possible, the preservation in Mark of cultural and linguistic features of the Eastern Mediterranean rural

\footnotetext{
${ }^{26}$ See Aryeh Kasher, Jews and Hellenistic Cities in Eretz-Israel: Relations of the Jews in EretzIsrael with Hellenistic Cities during the Second Temple Period 332 BCE-70 CE (Tübingen: Mohr, 1990), 78-104.

${ }^{27}$ See p. 28, n. 96.

${ }^{28}$ See Iverson, Gentiles, 1-3; Roskam, Mark, 94-96; Vander Broek, “Sitz im Leben,” 88-130, 190300.

${ }^{29}$ The terms "Gentiles" and "Gentile" appear a total of 44 times in the Gospels and Acts. Their influential presence seems to affect almost every aspect of life in first-century Palestine.
} 
or village culture, features which Luke, in writing to a Gentile audience, eliminates or alters, speaks against Rome." ${ }^{30}$

Weeden finds it difficult to place the setting of the Gospel outside of Palestine since Mark's audience is placed within a context of "conflict between Jesus and the religious leaders . . . at the outset of Jesus' ministry"; and that this conflict is "accelerated" as the narrative progresses. ${ }^{31}$ Catchpole asserts that "when scholars speak of 'the Palestinian situation' in Mark, for example, [they] refer to the inability of a Jewish woman to divorce her husband (10:12)"32 but this is not necessarily so. Judaism, for certain conditions, permitted a woman to initiate divorce, but not in a unilateral fashion as permitted to men. A court could simply compel a husband to write his wife a certificate of divorce if it found her reasons to be legitimate. Some of these legitimate conditions are stated in the Mishnah: "If the husband practices the craft of coppersmith, if he is a tanner, if he is inflicted with boils, or if he renounced his Jewish religion." ${ }^{, 33}$ Talmudic sources indicate that a wife could "torment him [enough] until he lets her go with a bill of

\footnotetext{
${ }^{30}$ Kee, Community, 102.

${ }^{31}$ Weeden, Mark, 21.

${ }^{32}$ Catchpole, "Synoptic Divorce," 111.

${ }^{33} \mathrm{~m}$. Ned 11:12; cf. $m$. Ketub 7:10. For a complete view over a Jewish woman's right to secure a divorce, see David Instone-Brewer, "Jewish Women Divorcing Their Husbands in Early Judaism: The Background to Papyrus Se'elim 13," Harvard Theological Review 92 (July 1999): 349-357; Barry E. Morgan, "The Synoptic Pericopes Concerning Divorce and Remarriage: An Exegetical and Hermeneutical Study" (Ph.D. diss., Southwestern Baptist Theological Seminary, 1987), 39-43; Ze'ev W. Falk, The Divorce Action by the Wife in Jewish Law (Jerusalem: Hebrew University, 1973); Mordechai A. Friedman, "Termination of the Marriage upon the Wife's Request: A Palestinian Ketubba Stipulation," Proceedings of the American Academy of Jewish Research 37 (1969): 29-55; and Aaron Jacob Skaist, "Studies in Ancient Near Eastern Marriage and Divorce Law" (Ph.D. diss., University of Pennsylvania, 1963), 134-137. For
} more, see my exegesis in chapter 5 . 
divorce" 34 and that "the rabbis observe that in some Gentile nations the wife may expel her husband."35

Whatever the case, Catchpole still concedes that many scholars "omit the fact that 'Palestinian' is not at all synonymous with Jewish, and that only a relative minority of the Palestinian population were subjected to Jewish customs." 36 The inroads that Hellenism had made into Palestine are not generally factored into the arguments of defenders of a Roman audience of the Gospel, as we shall see below and in the following chapters. Nevertheless, because Mark supposedly betrays a Gentile situation, some of the scholars who favor a Roman setting work under the assumption that Palestine was devoid of all alien cultural and political influences.

Proponents of a Roman Gentile audience seem to miss the reality of the cultural and political conditions of Palestine during the first century. Tolbert stresses quite correctly that "attempts to divide sharply the Jewish heritage of Christianity from the Greek heritage [in Palestine] fail to recognize the degree of Hellenization already part of the Jewish culture."37

Proponents of a Roman audience of Mark have failed to recognize that "Hellenistic culture displayed a spectrum of cultural assimilation from more consciously

\footnotetext{
${ }^{34} y$. Ketub 5:1, Jacob Neusner, trans., The Talmud of the Land of Israel (Chicago: University of Chicago Press, 1982-1991), 22:166.

${ }^{35} y$. Qidd 58c; cf. Gen Rabbah 2:24.

${ }^{36}$ Catchpole, "Synoptic Divorce," 111.

${ }^{37}$ Mary Ann Tolbert, Sowing the Gospel: Mark's World in Literary Historical Perspective (Minneapolis: Fortress, 1989), 37.
} 
native to more consciously Hellenized, [even though] the positions along this spectrum were matters of differences in degrees, not in kind, all were Hellenized."38

Hengel's assertion that "by the time of Jesus, Palestine had been under 'Hellenistic' rule and its resultant cultural influence for some 360 years," 39 needs to be taken more seriously. Many scholars have shown that Hellenism had a way of permeating the whole of society. Goodman writes:

Jews in the eastern Mediterranean world were affected by the same momentous political, economic, cultural, and social changes which occurred in this period as were their non-Jewish neighbours [sic]. It would seem strange indeed if Jewish reactions to the rise of the Roman power, to the emergence of massive interregional trade, to the spread of Greek culture, and to the increase in urbanism did not parallel in some way those of other peoples. ${ }^{40}$

While Southern Palestine may have remained more "Jewish," 41 Galilee, in a special way, appeared to lack most of the trappings of the Jewish religion and way of life of Southern Jews, and precisely because of this lack of strong Jewish influences, they

\section{${ }^{38}$ Ibid., 38 .}

${ }^{39}$ Martin Hengel, Judaism and Hellenism: Studies in Their Encounter with Palestine during the Early Hellenistic Period, trans. John Bowden (London: SCM Press, 1974), 1:1. Cf. Martin Hengel, Jews, Greeks, and Barbarians: Aspects of the Hellenization of Judaism in the Pre-Christian Period, trans. John Bowden (Philadelphia: Fortress, 1980), 36-39; Séan Freyne, Galilee from Alexander the Great to Hadrian: 323 B.C.E. to 135 C.E. (Notre Dame, IN: University of Notre Dame Press, 1980), 139-141; also K. W. Clark, “Galilee," The Interpreter's Dictionary of the Bible, ed. George Arthur Buttrick (Nashville: Abingdon, 1962), 2:334-347.

\footnotetext{
${ }^{40}$ Martin Goodman, "Jews, Greeks, and the Romans," in Goodman, Jews in a Graeco-Roman
} World, 4. Goodman goes on to outline the extent the Greco-Roman influence in trade, the arts, and even entertainment (4-7); cf. Avigdor Tcherikover, Hellenistic Civilization and the Jews, trans. S. Applebaum (Philadelphia: Jewish Publication Society of America, 1959), 118-120.

${ }^{41}$ Mainly because the Jewish ruling religious classes lived there, yet, it has been shown that some of them were precisely the first ones to adopt Hellenistic lifestyles. See James S. Jeffers, The Greco-Roman World of the New Testament Era (Downers Grove, IL: InterVarsity, 1999), 54, 57, 116, 123-125; cf. Albert A. Bell, Jr., Exploring the New Testament World (Nashville: Thomas Nelson, 1998), 28-29, 44, 58, 146147. 
considered Galilee "less Jewish" than the rest of Palestine. ${ }^{42}$ Recent studies ${ }^{43}$ suggest that only a small minority of Galilean Jews appear to have been subject, or subjected themselves, to Jewish customs.

If historical records are correct, first-century Galilee seemed far from being a "purely" Jewish region. Barnett has noted that "by the time of Jesus the agricultural world of Galilee owed more to the Ptolemaic era than to covenantal history." ${ }^{44}$ Vermes quotes a certain rabbi who, after spending an apparent eighteen fruitless years in Galilee, exclaimed: "Galilee, Galilee, you hate the Torah!" "A5 And it was precisely for this lack of seriousness towards "Jewish" things and religion that Southern Jews showed little respect for Galilee and Galileans.

Galilee was considered culturally backward, and since most Galilean Jews did not belong to religious classes, its peasants and laborers were derided. First-century rabbinic literature portrays Galileans as second-class citizens. They were the center of ethnic jokes. Their slipshod ways of speaking the common language made them readily identifiable (see Matt 26:73). ${ }^{46}$

\footnotetext{
${ }^{42}$ See Séan Freyne, Galilee, Jesus, and the Gospels: Literary Approaches and Historical Investigations (Philadelphia: Fortress, 1988), 41-50, 69-103; Séan Freyne, "The Galileans in the Light of Josephus' Life," in Galilee and the Gospels: Collected Essays (Tübingen: Mohr Siebeck, 2000), 27-44. Even in the Gospels, any and everything Galilean appears to be less "Jewish" (see Luke 13:1-2; John 1:45$46 ; 7: 41,52 ; 19: 19)$.

${ }^{43}$ For a comprehensive overview, including bibliographical references, see Séan Freyne, "Town and Country Once More: The Case of Roman Galilee," in Galilee and the Gospels: Collected Essays (Tübingen: Mohr Siebeck, 2000), 59-72; cf. Iverson, Gentiles, 1-3. 49.

${ }^{44}$ Paul Barnett, Jesus and the Rise of Early Christianity (Downers Grove, IL: InterVarsity, 1999),

${ }^{45}$ Geza Vermes, Jesus the Jew: A Historian's Reading of the Gospels (London: Collins, 1973), 53.

${ }^{46}$ The Aramaic words found in the Gospels not only demonstrate that Jesus spoke this northern dialect. The fact that he hailed from Galilee played against him: "Can anything good come from Nazareth?" (John 1:46) must have been the general reaction towards Galileans. John (7:52) also notes that as
} 
Given the overwhelming evidence of the extent of Hellenistic influences in

Palestine, and quite evident in Galilee, ${ }^{47}$ it is surprising that scholars would still contend that "Greek cities were almost exclusively on the border and that the Galilean interior was un-Hellenized,"48 or that "Jesus was not at all affected by Hellenism." ${ }^{\text {"49 }}$ Recent studies seem to point out that the lower parts of Galilee, where Jesus grew up, were affected by Greek influence much more than what had been previously supposed. Sepphoris, "the ornament of Galilee," 50 is a case in point. Excavations at Sepphoris since 1983 have shown that it possessed all the privileges of a Greek city. ${ }^{51}$ Although it is not evident in the Gospels whether Joseph spoke Greek, as any tradesman would need to in order to survive, ${ }^{52}$ it would seem unlikely that Jesus, the tradesman's son, would not be impacted by this center of Greek culture with 30,000 people and less

Nicodemus spoke up in defense of Jesus, he was silenced with a retort: "Are you from Galilee, too? Look into it, and you will find that a prophet does not come out of Galilee." Cf. Philip Yancey, The Jesus I Never Knew (Grand Rapids, MI: Zondervan, 1995), 60-61.

${ }^{47}$ See Mark A. Chancey, Greco-Roman Culture and the Galilee of Jesus (New York: Cambridge University Press, 2005), 63-66; cf. Martin Goodman, ed., Jews, 77-81.

${ }^{48}$ Louis H. Feldman, "How Much Hellenism in Jewish Palestine?" Hebrew Union College Annual 57 (1986): 95. Feldman goes on to contend that the extent of Hellenization in Palestine was late and superficial (83-111). See Martin Hengel, "Judaism and Hellenism in Retrospect," JBL 96 (1977): 371-382, who earlier had said the opposite; cf. Chancey, Greco-Roman Culture, 44-47.

${ }^{49}$ Joseph Klausner, Jesus of Nazareth: His Life, Times, and Teaching (1925, repr., New York: Macmillan, 1964), 363.

${ }^{50}$ See Eric M. Meyers, Ehud Metzer, and Carol L. Meyers, "Sepphoris: 'Ornament of All Galilee,” Biblical Archaeology Review (BAR) 49 (1986): 4-19; cf. Josephus, Antiquities, 18.2.1.

${ }^{51}$ For more on Sepphoris and its standing relation to the rest of Galilee, see Séan Freyne, "Christianity in Sepphoris and in Galilee," in Galilee and the Gospels: Collected Essays (Tübingen: Mohr Siebeck, 2000), 299-307; Thomas R. W. Longstaff, "Nazareth and Sepphoris: Insights into Christian Origins," Supplement to AThR 11 (1990): 8-15; Eric M. Meyers, "Artistry in Stone: The Mosaics of Ancient Sepphoris," BAR 50 (1987): 223-231; Shirley Jackson Case, "Jesus and Sepphoris," JBL 45 (1926): 14-22.

${ }^{52}$ Inscriptions in Palestine "prove beyond a reasonable doubt that the majority of Jewish families could read and write Greek," writes Eric M. Meyers and James F. Strange, Archaeology, the Rabbis, and Early Christianity (Nashville: Abingdon, 1981), 82; cf. Saul Lieberman, Greek in Jewish Palestine (New 
than five miles from his hometown of Nazareth. ${ }^{53}$ Lee's assessment that "Sepphoris did not inculturate Galilee" ${ }^{, 54}$ may prove to be inaccurate.

That Judaism came in direct contact with Hellenism at Sepphoris is evidenced in the rabbinic writings. Jewish legal disputes were held there until the destruction of the second temple. ${ }^{55}$ Yet Sepphoris is but one city which may have exerted strong Hellenistic influence on Galilee. There was also Tiberias, founded by Herod Antipas (ca $14 \mathrm{CE}$ ), ${ }^{56}$ as there were also the ten Greek cities known as the Decapolis. Currently located in Jordan (except for Damascus and another one west of the Jordan), these ten cities were founded during the Hellenistic period between 323 and $63 \mathrm{BCE}$ and exerted an enormous influence on the Nabatean, Aramean, Syrian, and Jewish populations in which they were located, as they were centers of Greek and Roman culture. ${ }^{57}$

York: Jewish Theological Seminary of America, 1994), 1-67; and Freyne, Galilee from Alexander the Great, 151, who asserts that koine Greek was spoken by the lower classes.

${ }^{53}$ See John Kenneth Riches, “The Social World of Jesus,” Int 50 (1996): 383-393; cf. Richard A. Batey, Jesus and the Forgotten City: New Light on Sepphoris and the Urban World of Jesus (Grand Rapids, MI: Baker, 1991), 13-17; and G. R. Selby, Jesus, Aramaic, and Greek (Doncaster, UK: Brynmill, 1989), 32-35.

${ }^{54}$ Bernard J. Lee, The Galilean Jewishness of Jesus: Retrieving the Jewish Origins of Christianity (New York: Paulist, 1988), 63.

${ }^{55}$ See m. Yoma 6.3; m. B. Metzi’a 8.8; m. B. Bat. 6.7; m. Arak. 9.6.

${ }^{56}$ See Lee, Galilean Jewishness, 63.

${ }^{57}$ For the extent of the influence these cities exerted over the region, and especially Galilee, see Achim Lichtenberger, Kulte und Kultur der Dekapolis: Untersuchungen zu numismatischen, archäologischen und epigraphischen Zeugnissen. Abhandlungen des Deutschen Palästina-Vereins, Band 29 (Wiesbaden: Harrassowitz Verlag, 2003), 47-59; Mark A. Chancey and Adam Porter, "The Archaeology of Roman Palestine," Near East Archaeology (NEArch) 64, no. 4 (December 2001): 164-198; Claire Epstein, "Hippos (Sussita)," The New Encyclopedia of Archaeological Excavations in the Holy Land, ed. Ephraim Stern (Jerusalem: Israel Exploration Society, 1993), 2:33-37; Harold W. Mare, "Decapolis," Eerdmans Dictionary of the Bible, ed. David Noel Freedman (Grand Rapids, MI: Eerdmans, 2000), 44; Thomas S. Parker, "The Byzantine Period: An Empire's New Holy Land," NEArch 62, no. 3 (September 1999): 134-171. 
Gadara, for example, long considered a center of Greek learning by historians, was one of the most brilliant ancient Greco-Roman cities of the Decapolis and the resort of choice for Romans who vacationed in the nearby Hammat Gader Springs. ${ }^{58}$ Since ancient times Gadara was strategically situated, laced by a number of key trading routes connecting Syria and Palestine by the first century CE. This town also flourished intellectually in the reign of Augustus and became distinguished for its cosmopolitan atmosphere; a city that attracted writers, artists, philosophers, and poets. ${ }^{59}$ Notable Greek Cynics such as Oenamus, the satirist Menippus, the epigrammist Meleager, and the rhetorician Theodoros, all hailed from Gadara. Meleager left the following inscription: "Island Tyre was my nurse, and Gadara, which is Attic (as regards to culture), but lies in Syria $^{60}$ gave birth to me. ${ }^{61}$ Theissen has shown that from other neighboring nonPalestinian cities hailed notables such as the Epicurean Philodemus, the Stoic Antiochus, who was born in Ashkelon, Southern Palestine. Both the Sceptic Heraclitus and the Peripatetic Diodore were from Tyre, and both the Epicurean Zeno and the Peripatetic Boethus hailed from Sidon, regions that surrounded Galilee and that must have had strong cultural influence there. ${ }^{62}$

${ }^{58}$ See Hengel, Hellenism: Studies, 1:83-88.

${ }^{59}$ See ibid.; cf. Hengel, Barbarians, 36-39.

${ }^{60}$ Some of the cities of the Decapolis flourished during the Ptolemaic dynasty until 198 BCE. Others were either founded or flourished later under Seleucid rule. See Thomas Weber and Rami G. Khouri, Umm Qais: Gadara of the Decapolis (Amman: Al Kutba, 1989), 33-35.

${ }^{61}$ William Roger Paton, trans., The Greek Anthology, Loeb Classical Library (LCL) (Cambridge: Harvard University Press, 1939), 2:223.

${ }^{62}$ See Theissen, Sociology, 88-89. 
Archaeological surveys indicate that Gadara was occupied as early as the seventh century BCE and became a city of "invaders" for centuries to come. ${ }^{63}$ Polybius, the Greek historian, describes the region as being under Ptolemaic control. The Seleucid ruler Antiochus III conquered it in 218 BCE, naming the city Antiochia and Seleucia. For well over half the first century CE Gadara had been under Hellenistic rule since Antiochus had conquered it along with all the surrounding cities, including the Decapolis to the southeast. $^{64}$

As to the lack of treatment of the Gentile characters in Mark, Iverson writes, "It is striking to find that little scholarly work has been devoted to Mark's portrayal of Gentile characters. ${ }^{\prime 65}$ He goes on to put forth an array of evidence in how Mark describes Jesus' Gentile ministry in Galilee in what he calls "Journeys into Gentile territory" for which he identifies five. One of those journeys (the second one), he notes, somewhat stalls because the disciples" "hearts were hardened" (Mark 6:52), "symptomatic" of the twelve. ${ }^{66}$

Iverson identifies eleven encounters Jesus had with Gentile characters, six of which were in Galilee, the other five in Jerusalem at his crucifixion and after his resurrection. ${ }^{67}$ The Markan story of a demon-possessed man (Mark 5:1-20) in Jesus'

\footnotetext{
${ }^{63}$ See Weber and Khouri, Umm Qais, 33-35.
}

${ }^{64}$ See Polybius, The Histories, ed. William Roger Paton, LCL (Cambridge, Harvard University Press, 1922-1927), 3:173-175.

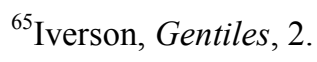

${ }^{67}$ The crowd by the sea (3:7-12); the Gerasene demoniac (5:1-20); the Syrophoenician woman (7:24-30); the deaf man (7:31-37); the four thousand people (8:1-9); the blind man (8:22-26); the father with the demon-possessed son (9:14-29); Pilate (15:1-15, 432-47); the soldiers (15:16-41); Simon of Cyrene (15:21), and the centurion (15:39, 44-45). Iverson, Gentiles, 3. 
"first journey into Gentile territory," 68 the presence of swine, a ritually unclean animal to religious Jews, unfolds "in the country of the Gadarenes," Jewishness of this region in such close proximity to Galilee where Jesus spent much of his life and ministry. The reaction of the town's people against the porcine destruction indicates strong Gentile presence in this lakeside region of the Decapolis, just east of the Jordan.

The Markan passage may also be implying the presence of both Jews and Gentiles in the city viewed in Mark's sensitive treatment of the "clean" and "unclean" distinctions. In regard to these distinctions Kelber observes: "It is on Gentile ground that the Jewish prerogative of the Kingdom is affirmed. Mark, it seems, has taken great pain to give equal recognition to the Jewish and Gentile side alike."${ }^{, 70}$

It has also been noted that another of Mark's hints of a truly significant Gentile presence in Galilee is found in reference to Jesus' two feedings of great crowds. In the last act into his "third journey" J1 Jesus feeds four thousand (Mark 8:1-9). There were twelve remaining baskets of bread identified as $\sigma \pi u \rho i \delta \omega \nu$ in Mark 8:20. As they leave, a situation develops concerning their lack of bread, for which, again, Jesus points to their

$$
{ }^{68} \text { Ibid., 20-39. }
$$

${ }^{69}$ Historical and geographical discrepancies in the Gospel narratives have been noted by Bible students. Matthew (8:28) correctly calls it "the country of the Gadarenes" and identifies two demoniacs; while Mark $(5: 1)$ and Luke $(8: 26,37)$ incorrectly call this territory "the country of the Gerasenes" and identify one demon-possessed man. Gadara (modern Umm Qays) is nearest the Sea of Galilee and most likely the biblical locale. Jerash (ancient Gerasa), on the other hand, is much farther to the southeast, and quite a ways from the Lake of Tiberias. For a historical description of the Decapolis, see Pliny the Elder, Natural History, trans. H. Harris Rackham and W. H. S. Jones, LCL (Cambridge: Harvard University Press, 1961), 2:74-77.

\footnotetext{
${ }^{70}$ Kelber, Kingdom, 60 .

${ }^{71}$ For the details of this encounter, see Iverson, Gentiles, 40-82.
} 
"hardened hearts" (8:17). For their lack of faith he reminds them how he just fed four thousand and still had seven baskets ( $\sigma \pi u p i ́ \delta \omega \nu)$ left over (Mark 8:20), and reminds them of another feeding that involved five thousand, and there again there were twelve baskets (кофívous) left over (Mark 8:19). The terms used for "baskets," кoфívous (Mark 8:19) and

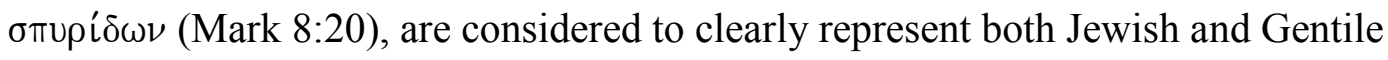
groups, respectively. ${ }^{72}$

What Mark narrates at the end of his Gospel provides clues to Roskam that Mark's Gospel had its origin in Galilee. ${ }^{73}$ This narration implies Mark's interest in reaching the Gentile community in Galilee and consists of the introduction of three Galilean women at Jesus' crucifixion in Jerusalem: Mary of Magdala, Mary the mother of James the younger and Joses, and Salome (Mark 15:40-41). Roskam notes that none of the three have been mentioned before and that they just stand there. "They are Galilean women who took care of Jesus during his ministry in Galilee," who came to Jerusalem perhaps not knowing what would happen to him there. Their presence at the tomb on Sunday morning to anoint his body, says Roskam, was "a preparatory function: they are intended to guarantee the reliability of the story about the empty tomb in Mk 16 and the reality of Jesus' bodily resurrection" to their fellow Gentile believers as they returned to Galilee. $^{74}$

\footnotetext{
${ }^{72}$ See Walter Bauer, A Greek-English Lexicon of the New Testament and Other Early Christian Literature, $3^{\text {rd }}$ ed., ed. Frederick W. Danker, William F. Arndt, and Wilbur F. Gingrich (BDAG) (Chicago:

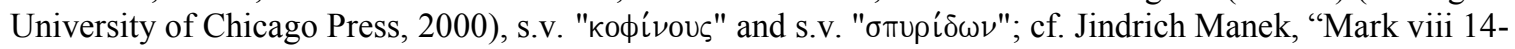
21," NovT 7 (1964-1966): 10-13; and Alan Richardson, The Miracle-Stories of the Gospels (London: SCM Press, 1956), 98.

${ }^{73}$ For those other clues, see Roskam, Mark, 95-100.

${ }^{74}$ Roskam, Mark, 101; cf. Telford, Mark, 25; Telford, Theology, 14.
} 
It is worth noting how "Mark has refrained from any explicit discussion of Gentile inclusion in the kingdom of God," writes Iverson, but she notes "that after Jesus declares all food clean (7:14-23), he departs for the unclean territory of the Gentiles where his instructions to the disciples about an inclusive table takes center stage." 75 The Gentiles in Galilee are the people to whom the Markan Jesus ministered, and to whom Mark, the evangelist, appears to have directed his Gospel of the resurrected and ascended Christ.

\section{Mark's Use of Foreign Terms}

By addressing his Gospel to a predominantly Gentile audience (allegedly in Mark's use of Latinisms, his transliteration of Aramaisms, and envisioning a divorce initiated by a woman), would this necessarily imply an audience outside of Palestine? Some scholars have considered the Gospel of Matthew, for example, to have had an audience other than a Jewish one ${ }^{76}$ precisely because in various occasions its author translates Aramaic words, changes phrases from the Aramaic into the Hebrew, ${ }^{77}$ and leaves Latinisms untranslated; ${ }^{78}$ yet there are those who, although lending support to this view, do not consider the evidence conclusive. ${ }^{79}$

\footnotetext{
${ }^{75}$ Iverson, Gentiles, 40.
}

${ }^{76}$ Some early $20^{\text {th }}$-century scholars argued seriously for a Syrian audience; see Bacon, Matthew, 323; cf. Burnett Hillman Streeter, The Four Gospels (London: Macmillan, 1937), 500-503.

${ }^{77}$ That Matthew targeted a Palestinian Jewish audience, especially the Southern kind, may be seen in his "anti-Pharisaic tone." See Guthrie, Introduction, 33; cf. Sjef van Tilsborg, The Jewish Leaders in Matthew (Leiden: Brill, 1972), 166-169.

${ }^{78}$ Aramaic words such as "Golgotha ... the place of the skull" (Matt 27:33), or changing a phrase from Aramaic into Hebrew "Eli, Eli, lama sabachthani?" to "Eloi, Eloi, lama sabachthani?" (Matt 27:46; cf. Mark 15:34) may be an indication that Matthew, although writing for a Jewish audience, is also aware of his Gentile audience. See Guthrie, New Testament Introduction, 38; cf. Goulder, Midrash, 34-37. Also, Matthew's (27:27) use of the term praetorium, for example, may be another indication that he is aware of 
Mark's use of Latinisms and his explanation of Aramaic terms can be explained only by reminding Roman audience proponents that Palestine was an occupied territory of Rome with a large contingency of Roman soldiers, merchants, and enough non-Jewish residents that would qualify Galilee as "Galilee of the Gentiles" (see Isa 9:1; 1 Mac 5:15; Matt 4:15). ${ }^{80}$ Roskam has noted that “the Latinisms in Mark's Gospel are mainly military, administrative, or commercial terms [which] could easily spread throughout the Roman world. . . . Their use was certainly not restricted to Rome." ${ }^{81}$ One may never know, for example, how many other Romans may have come in contact with Jesus in Galilee, as did the centurion in Capernaum (Luke 7:2-10). Luke, when narrating the events related to Pentecost in the book of Acts, lists Jews, who by virtue of the Diaspora, had come from many countries to worship in Jerusalem. These Jews no longer understood Aramaic as evidenced in their astonishment in understanding the preaching of

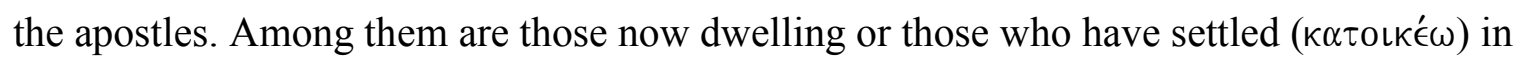

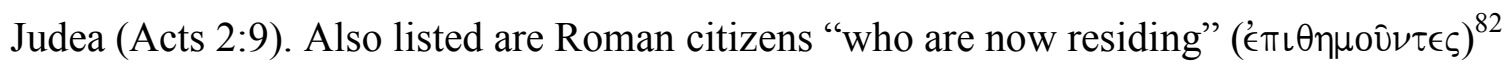

his Gentile audience or a Jewish audience that does not speak Aramean (see Acts 2:9-10). Cf. F. Blass and A. Debrunner, A Greek Grammar of the New Testament, ed. and trans. Robert W. Funk (Chicago: University of Chicago Press, 1961), 187. For Matthew's other Latinisms see, ibid., 23-24; cf. Vander Broek, "Sitz im Leben," 200-201.

${ }^{79}$ See Wolfgang Trilling, The Gospel according to St. Matthew (New York: Herder and Herder, 1969), 1:35-39; cf. John P. Meier, Law and History in Matthew's Gospel: A Redactional Study of Matt 5:17-48 (Rome: Biblical Institute Press, 1976), 14-21, and Georg Strecker, Jesus Christus in Historie und Theologie (Tübingen: Mohr, 1975), 17-21.

${ }^{80}$ See G. H. Boobyer, “Galilee and Galileans in St. Mark’s Gospel,” BJRL 35 (1953): 336-339.

${ }^{81}$ Roskam, Mark, 94-95; cf. Telford, Mark, 24; Kelber, Kingdom, 129.

${ }^{82}$ The translation of the Greek ' $\epsilon$ ' $\theta \eta \mu$ ov̂ $\tau \in \varsigma$ as "residing" is well attested in various translations such in different versions of the Spanish Reina-Valera (1960, 1995), New Jerusalem Bible, French and Portuguese versions. 
in Jerusalem and other parts of Palestine (Acts 2:10) and who evidently did not understand Aramaic.

When a large number of the Galilean population and those beyond the immediate Galilean borders are considered to be of Gentile origin or foreign-born Jews living under Greco-Roman customs (and even laws), it is not difficult to understand Mark's use of Latinisms and his need to explain Aramaic terms. ${ }^{83}$ As to Mark's Latin terminology, Lane, following Ramsay_-both supporters of Mark's Roman origin—argues that the lepton $^{84}$ was in circulation in the East, thus Mark had to provide an equivalent value for his Roman readers, the Roman quadran, ${ }^{85}$ given the influence of Roman presence in occupied territories and the presence of Western merchants in Palestine; ${ }^{86}$ for as Marcus clarifies, "Mark is not [necessarily] substituting western terms for eastern equivalents, but explaining imprecise words by means of precise Latin ones." ${ }^{97}$ Interestingly enough, Luke (21:2), writing to an assumed Gentile audience, does not bother to explain for his readers the widow's lepta, the precise coins for which Mark (12:42) is found to give a Roman equivalence. The Latin word praetorium is another case in point. Both Matthew

\footnotetext{
${ }^{83}$ For a synthesis of Greco-Roman influences in Palestine, of both language and customs, see Bell, Exploring, 19-30.

${ }^{84}$ The small Greek coin of Palestine minted in Maccabean times is mentioned in Mark (12:42-44) in reference to the widow's temple offering.

${ }^{85}$ See Lane, Mark, 442-443. Cf. Avi-Yonah has shown that the quadran was used in the East where its equivalence has been transliterated in Judea since the second temple period. See Michael AviYonah, The Herodian Period, The World History of the Jewish People 7 (London: Allen, 1975), 198.

${ }^{86}$ See Kelber, Kingdom, 129n1, who states that Latin military and economic terms were common in occupied territories.

${ }^{87}$ Marcus, Mark 1-8, 32; cf. Marcus, "Jewish War,” 443-446.
} 
(27:27) and Mark (15:16) leave it untranslated, evidence that words such as this would be well known to Jews in occupied territories.

Marxsen, in an analysis of the Latin terms found in Mark, has forcefully shown that the Gospel's Latinisms stem from Galilean sources, rather than from Roman ones. ${ }^{88}$ It has also been noted that Mark did not always translate foreign words. Terms such as the Hebrew hosanna (Mark 11:9) and the Aramaic amen (13 times in Mark) are words Mark may have not considered unintelligible to his Gentile audience who may have been familiar with Galilean Jews and their synagogues. Gentile familiarity with such Jewish terms seems to have contributed to Mark's omission to translate them. ${ }^{89}$

In regard to the Aramaisms, Mark could have done two things: (1) omit them in an attempt to appear more "updated" than his sources in relation to his audience and (2) retain them. Opting to retain the Aramaic words in his Gospel may indicate, with a high degree of probability, that these Aramaic words came from Mark's sources, sources to which he remained loyal. Rather than omit them, Mark chose to translate them for his audience.

Mark lived in a world in which Greek, the language of commerce and of day-today communication, and a world in which Latin was trying to establish itself as the language of the empire, was in need of the gospel. For as Kee rightly ponders, Mark was conscious that the "formulaic expressions [of evangelism] would continue [and indeed

${ }^{88}$ See Willi Marxsen, Mark, 66-67.

${ }^{89}$ See Kee, Community, 102. Cf. Barnabas Lindars, New Testament Apologists: The Doctrinal Significance of O.T. Quotations (Philadelphia: Westminster, 1961), 171-173, who argues that words such as hosanna and $\alpha \mu \eta \nu$ may have remained untranslated because they became part of the liturgy of the early church, thus coming into common usage among Gentile Christians. 
needed] to reflect the underlying Aramaic thought-patterns." ${ }^{, 90}$ When Mark's motives are questioned in regard to maintaining "original" words, perhaps one should consider that what Mark shows in his Gospel is the necessity that a bilingual or even a trilingual society must have the gospel. The Gospel of Mark shows that its author is conscious of his world.

It seems, therefore, safe to say that Mark's use and translation of Aramaic words, and his use of Latinisms, all function in a context of relationships between Jews and Gentiles in Palestine. Mark does not remain faithful only to his original sources (by retaining the Aramaic) and relevant to his audience (by his use of Latin), but Mark remained conscious of his duty to preach the message of Jesus to Gentiles by explaining terms that may not have been familiar to those in their adopted or occupied territory.

\section{Summary and Conclusions}

The transport-setting of the Gospel of Mark from Palestine to Rome was done mainly on the number of Latinisms the Gospel contains and the apparently odd statement of Mark 10:12 within a Palestinian-Jewish understanding in which a woman may not divorce her husband. It seems safe to conclude, however, that the Gentile orientation of the Gospel of Mark, reason for a Roman audience assumption, appears to be more compatible with a Palestinian-Gentile audience given the general thrust of the Gospel.

A Gentile understanding of a woman divorcing her husband, a connection that may be found in the Pharisaic-Herodian plot against Jesus, in the context of the Markan Gospel, Mark 10:12 makes perfect sense in Palestinian territory. Given the known facts

\footnotetext{
${ }^{90}$ Kee, Community, 101.
} 
of the extent of Gentiles living in Northern Palestine, there seems to be no need to transport the Markan Gospel to Rome. Furthermore, it does seem odd that a Gospel written to a Gentile audience in Rome would not contain any references about a city as important as this one, or of the people being addressed and the circumstances in which these new believers would have received both the gospel (the written account) and the Gospel (the Good News) in view of the impending Jewish rebellion rising up and a major point of concern in the Empire.

If in fact the Gospel of Mark was written between 60-61 CE as most NT scholars contend, then Mark's description of the trauma of the pre-70 events related to the fall of Jerusalem and destruction of the temple would not have been as meaningful to Christians in far-away Rome. For Gentile-Christians in Galilee, however, these events would have been very real and compelling in the dramatic time and place in which they were living. ${ }^{91}$ For as Vander Broek aptly states: "We would have to assert that evidence suggests that the gospel was produced [for] a community which existed in temporal and spatial proximity to the Jewish war." ${ }^{92}$ Jesus' preaching throughout Galilee (Mark 1:28, 39), the references to Galilee in Mark with implications of a Gentile mission (Mark 3:7-12), the detailed descriptions of Herod's birthday feast "with the chief men of Galilee" in which John the Baptist was decapitated (Mark 6:21-27), Herodias's divorce according to Roman

\footnotetext{
${ }^{91}$ Ibid., 42-43.

${ }^{92}$ Vander Broek, "Sitz im Leben," 245.
} 
law (Mark 10:10-12), ${ }^{93}$ could all be understood by both Jewish and Gentile residents of Galilee without major explanations. ${ }^{94}$

Whatever vocabulary Mark used to make the gospel relevant is illustrative of the ethnic nature of his audience, consisting of both Jews and Gentiles. Those so-called "foreign" expressions and explanations found in Mark are in no way indicative that this Gentile audience had necessarily to live outside of Palestine. When scholars underplay the immense role of the Greco-Roman culture in Palestine, with the widespread use of the Greek language and customs, the emerging Latin language, the presence of foreign troops, the high level of non-Jewish groups living particularly in Galilee, and foreignborn Jews "now residing in Palestine" (Acts 2:9-10), they deny, by default, a reality of a first-century world in which the gospel first needed to be made accessible. "Homegrown" evangelists such as Mark were responding to Jesus' injunctions to bring the gospel "home" first (see Acts 1:8b). It seems therefore quite proper to consider Mark 10:1-12 as an original unit in which, to a Jew like John the Baptist, a foreign practice of divorce should not have been imported to Palestine, especially by the high and mighty as were those in the Herodian household. This study, therefore, will consider the Markan

\footnotetext{
${ }^{93}$ It becomes increasingly difficult to accept that, based on the pervasive nature of Greco-Roman influence on Palestinian life and the high density of Gentiles in Galilee; this would not affect and influence the divorce practices of Palestinians like Herod Antipas. That the Greco-Roman divorce practices would go unnoticed by the population seems untenable. Such practice was addressed and condemned by both John the Baptist and Jesus right in the rural heartland of Galilee. For an in-depth analysis see my exegesis in chapter 5 .

${ }^{94}$ For those who may raise the question as to why could not Mark write in Rome given that the Jewish historian, Josephus, wrote from there recounting all the elements of Jewish-Palestinian life, including the decapitation of John the Baptist; one can only answer by stating that Josephus wrote a general history of his Jewish people for his Jewish people, a people spread throughout the Roman Empire; while Mark, though it could be argued that he could have also written his Gospel in/from Rome, his intended audience clearly appears to be Gentile-Palestinan rather than a Gentile-Roman. The geographical detail, the Pharisaic debates, the Herodian plot against Jesus, etc., would seem unintelligible to Gentiles in Rome.
} 
pericope on "divorce" under the assumption that Mark wrote for a specific community within the confines of Palestine. 


\section{CHAPTER 3}

\section{MARRIAGE AND DIVORCE UNDER THE ROMANS: FIRST CENTURY BCE TO FIRST CE}

\section{Introduction}

Among the many statements identified in Mark which purportedly betray its Roman setting, no other statement of the Gospel has been given greater weight than Mark 10:12: "And if she divorces her husband and marries another, she commits adultery." This Markan statement has been pointed out as clearly referring to the Roman divorce practices in which the wife had the right and freedom to initiate and obtain her legal release. ${ }^{1}$ Other than allusions or the occasional footnote, no systematic study in the actual Roman practice pertaining to the Markan statement could be found that specifically addresses the question of divorce among the Romans.

The purpose of this chapter is an attempt to understand the extent of the so-called "Roman influence" in the Markan "divorce" saying. We find it necessary to understand the background of this "Roman influence" in order to elucidate whether this "influence" could have extended to the area in which Jesus spent most of his ministry, i.e., northern Palestine, an area under Roman rule and densely populated by Gentiles, as attested in the previous chapter.

\footnotetext{
${ }^{1}$ Modern NT scholarship has shown a tendency to separate Mark 10:10-12 from the original Sitz im Leben alleging that it was an addendum of Mark or of the Hellenistic Church. For bibliographic
} 
For the sake of a contextual understanding of the topic, a brief overview of the laws pertaining to Republican times will be attempted, followed by some of the reforming laws introduced by Augustus with the arrival of the Empire. ${ }^{2}$

Because Roman laws were ever changing, and as the Republic strengthened and later declined, giving way to Imperial Rome with its control over vast real estate as well as over great numbers of peoples, this section is limited to the marriage and divorce laws as they affected Roman citizens of the first century BCE to the first century CE and perhaps a few decades beyond.

First-century (CE) Roman historian, Tacitus, murmurs against the moral state of Rome during the classical period. He expresses a kind of nostalgia and paints an idyllic picture of the morals of Rome's past. ${ }^{3}$ Tacitus chides the Augustan reform laws for not having produced the desired effects, especially in the area of marriage and family. He exclaims with irony, "Where the country once suffered from its vices, it is now in peril from its laws."4

The virtues of Rome's past, particularly in regard to marriage morals, are also exalted by Aulus Gellius. He muses that for the first five hundred years of Rome's history

references, see p. 27, n. 28.

${ }^{2}$ In my discussion on divorce in this chapter and the next, I have attempted to capture the Sitz-imLeben of Mark. I use both Jewish and Roman sources - sources that reflect the thinking of the time the Gospels were composed. Although these sources were codified decades later, such as the Mishnah (ca. 200 $\mathrm{CE}$ ), and sometimes centuries later, such as the Jewish Talmud (Jerusalem and Babylonian), Roman legal codes such as Justinian's, the legal opinions of jurists such as Ulpian and Paulus, and the Institutes of Gaius, their codification embodied a wide spectrum of thought and legislation in both Jewish and Roman worlds through the centuries prior and after New Testament times.

\footnotetext{
${ }^{3}$ Tacitus Annals 3.26 (trans. Jackson); Tacitus Histories (trans. Moore, LCL, 2:563).

${ }^{4}$ Tacitus Annals 3.25 .
} 
“no marriages were annulled" until Spurius Carvilius (Ruga) divorced (dimisit) ${ }^{5}$ his wife ca. $231 \mathrm{BCE}^{6}{ }^{6}$ although Valerius Maximus does report that Lucius Annius of Setia “divorced” (Latin dimittere, Greek $\alpha \phi i ́ \eta \mu \iota)$ his wife in 307 BCE, this "divorce” would have occurred approximately seventy-five years prior to Carvilius's divorce. ${ }^{7}$

More than two centuries prior to the deliberations of the decemviri, ${ }^{8}$ it was believed that Romulus had pronounced a series of laws, many of which affected marital life. These laws, according to Dionysius of Halicarnassus, were necessary because "some, taking their example from the beasts, have allowed men to have intercourse with women freely and promiscuously."9 Plutarch considered Romulus's laws "severe" because they forbade women "to leave" $(\alpha \pi 0 \lambda \in \iota \pi \epsilon \iota)$ their husbands while permitting the men to "expel" ( $\epsilon \kappa \beta \alpha \lambda \lambda \epsilon \iota \nu)$ their wives. ${ }^{10}$

\footnotetext{
5“"Dimisit" from where we get the English equivalent "to dismiss"” or "to send away." All Latin translations in this chapter were taken from P. G. W. Glare, ed., Oxford Latin Dictionary (OLD) (Oxford: Clarendon, 1982).

${ }^{6}$ See Gellius Attic Nights 4.3.1 (trans. Rolfe, LCL, 1:323). Besides Dionysius of Halicarnassus who agrees with Aulus Gellius as to the date of the so-called "divorce" (Dionysius Roman Antiquities 2.25.6-7 [trans. Cary, LCL, 1:385]); but there are others who disagree. Plutarch places it ca. 524 BCE. Theseus and Romulus, in Plutarch Lives 6.4 (trans. Perrin, LCL, 1:199). De Zamoras Maximus 2.1.4 places it ca. $604 \mathrm{BCE}$.

${ }^{7}$ See De Zamoras Maximus 2.9.2.

${ }^{8}$ Literally, the "ten men" refers to the ten judges encumbered with the responsibility of drawing up a body of laws in the transition from the regal period to the Republican system. These enactments served as the bases for the XII Tables of 451 BCE. Although they were gradually modified, they functioned as the standard during Republican times. For more, see Timothy J. Cornell, The Beginnings of Rome: Italy and Rome from the Bronze Age to the Punic Wars: c. 1000-264 BC (New York: Routledge, 1995), 74-76. Cf. ibid., 85-88; Howard Hayes Scullard, A History of the Roman World 753-146 B.C., $4^{\text {th }}$ ed. (New York: Methuen, 1980), 115-119.

${ }^{9}$ Dionysius Antiquities 2.24.4 (1:383). For a summary of some of these laws, see ibid., 2.25-27 (1:381-386).

${ }^{10}$ Plutarch Romulus 22, in Lives 1:162; Plutarch Roman Questions 14, in Plutarch Moralia (trans. Frank Cole Babbitt, LCL, 4:27).
} 
Dionysius of Halicarnassus lists adultery and wine-drinking as causes for which a man could "divorce" ( $\epsilon \kappa \beta \alpha \lambda \lambda \epsilon \iota \nu)$ his wife; ${ }^{11}$ while Plutarch lists three: "[for] using poisons, for substituting children, and for adultery"; and that if the husband "for any other reason sends his wife away" ( $\alpha \pi 0 \pi \epsilon \mu \psi \alpha \iota \tau$ ), he forfeited his property, half going to the wife and half to Ceres, the goddess of agriculture. ${ }^{12}$ Additionally, Plutarch lists a number of "divorces" that occurred prior to the third century BCE, divorces for reasons other than those stated by Romulus. ${ }^{13}$ This may confirm that Tacitus's and Gellius's romantic take on the divorce question of the past never really existed, for it appears that although divorces proper were not the normal practice, expulsion and/or abandonment was, as Karlowa suggests. ${ }^{14}$ S. P. Scott comments:

It cannot now be determined how much the permanency of matrimonial union was due to religious influence or to public policy, or whether the patria potestas of the husband, who held his wife in manum as a daughter, was not largely responsible for it; as irreconcilable conjugal disagreements owing to the weakness of human nature, must have been as frequent at Rome as elsewhere, and there is no reason to assume the contrary. ${ }^{15}$

As for Carvilius, regardless of the date of his "divorce," when called upon by the censors to respond for his act, he answered that he had entered into marriage "for the

\footnotetext{
${ }^{11}$ Dionysius Antiquities 2.25.6 (1:385). Aulus Gellius recounts a practice where members of the husband's family would kiss the wife with the sole purpose of detecting whether she had been drinking, since according to Dionysius this, too, was punishable by death. Gellius Attic Nights 10.23.1-2 (2:279).

${ }^{12}$ Plutarch Moralia 1:163.

${ }^{13}$ Plutarch Questions 14, in Moralia 1:27.

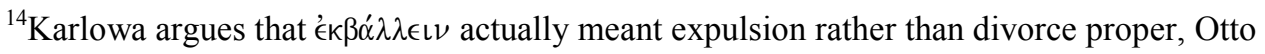
Karlowa, Römische Rechtsgeschichte (Leipzig: Veit, 1901), 2:185. It is interesting to note the Latin and Greek words used by the ancient writers. In this sense, Aulus Gellius may be right: Proper divorces may not have occurred for over five hundred years; rather, husbands simply may have deserted or expelled their wives from their homes. For a proper discussion of the different terms translated as "divorce" and their meaning in the original language, see the next pages of this chapter.

${ }^{15}$ Plutarch Questions 14, in Moralia 1:27.
} 
purpose of having children" and that his action "was based on necessity": his wife was barren. ${ }^{16}$ Evidently, Carvilius felt he had not transgressed a command of the XII Tables which stated: "If a husband desires to divorce $[\epsilon \kappa \beta \alpha \lambda \lambda \epsilon \iota \nu]$ his wife, and dissolve his marriage, he must give a reason for doing so." 17

\section{Marriage and Divorce Laws in Pre-Imperial Times}

The deterioration of the centuries-held effectiveness of pre-Imperial laws appears to have laid the foundation for that which would eventually bring Augustus's "leges novae" (new laws); ${ }^{18}$ reform laws that affected the lives of Roman citizens and noncitizens alike up to the fourth century $\mathrm{CE}$ when Christian emperors from Constantine I to Justinian, and Jurists such as Gaius, Ulpian, and Paulus, changed the legal scene.

Roman marriages from as early as Romulus varied according to social class. ${ }^{19}$ The legally recognized form of marriage was generally cum manu. ${ }^{20}$ It should be noted that although cum manu was the language of marriage, cum manu was not marriage. Whereas cum manu could not exist outside of marriage, marriage could exist without cum manu. ${ }^{21}$ The symbolic gesture in many present-day cultures of asking for the bride's hand

\footnotetext{
${ }^{16}$ Dionysius Antiquities 2.25 .7 (1:385). For the definitions of the Latin terms, see "marriage and divorce laws" below.

${ }^{17}$ Law of the XII Tables, Table VI, Law X. Agylaeus et al. Civil Law (trans. Scott,1:69).

${ }^{18}$ The Lex Julia of 18 BCE and the Lex Papia Poppaea of 10 CE.

${ }^{19}$ Namely, confarreatio and coemptio (see the discussion below). For a retracing of their histories, see Alan Watson, The State, Law and Religion: Ancient Rome (Athens: University of Georgia Press, 1992), 122-124; cf. Alan Watson, The Law of the Ancient Romans (Dallas, TX: Southern Methodist University Press, 1979), 231-234.

${ }^{20}$ “Coming into the hand of, seizing possession or appropriating of." Glare, OLD, s.v. "Manus."

${ }^{21} \mathrm{By}$ the late first century BCE and early first century CE, cum manu marriage was no longer the legally recognized institution for the general population in the Roman Empire. Marriage had become a matter of two adults consenting to live together. Aulus Gellius reports that during his time (second century
} 
is a relic of the ancient cum manu "marriage" which in most cases was nothing more than our modern engagement period (Latin comprometere; Spanish compromiso). ${ }^{22}$

When a daughter married, she left the patria potestas (paternal authority) of the father and came under the potestas (authority by way of cum manu) of the husband's father or grandfather, or in the absence of these two, the future husband himself. ${ }^{23}$ Any property she brought into the marriage became the property of her husband or of his paterfamilias (head of household, so to speak).

Obviously, divorce was in the hands of the one who held manus over a woman (generally, the paterfamilias). According to the jurist Gaius, the wife simply became like

$\mathrm{CE}$ ), betrothals, marriages, and divorces were still practiced under the cum manu arrangement only in Latium (ancient west-central Italy), as seen in the writings of the Jurist Servius Sulpicius, a contemporary of Cicero. Gellius, Attic Nights, 4.4 (1:325). For a detailed overview of the decline of cum manu marriage, see Karen K. Hersch, The Roman Wedding: Ritual and Meaning in Antiquity (Cambridge: University Press, 2010), 101-110, 211; cf. Susan Treggiari, Roman Marriage: Iusti coniuges from the Time of Cicero to the Time of Ulpian (New York: Oxford University Press, 1991), 288-291.

${ }^{22}$ In some Latin/Hispanic cultures, mine included, a prospective groom's official request for the bride's hand is a condicio sine qua non (a prerequisite) to be fully accepted into each other's family.

${ }^{23}$ The structure of the ancient Roman family is aptly summarized by A. Tighe as follows: "When we begin to study Roman history, no matter what the period, we are soon confronted by an institution which is quite foreign to anything existing in the present day. This is the patria potestas, or the peculiar power which a Roman father had over the members of his family. . . A man's family consisted of all his descendants to the remotest generations, provided their relationship with him could be traced through males. .. . When his sons took wives, they brought them under his control [paterfamilias]. All their children to the farthest limit were also included in the same body. His daughters, on the other hand, became free as to him by their marriage, because they passed into the membership [patria potestas] of another family. The relatives they thus acquired, and their own children, were counted as no kin of their father's family. .. . There was no such thing as relationship through women. Persons thus connected were called cognates (cognati, "relatives"), and between them early Roman law recognized no tie of blood. Those who were related through males were called agnates (agnati), and over this agnatic family the father (paterfamilias) exercised unlimited sway. All its members were to him as his slaves or his property, and under a bondage which was life-long. . . . He could sell or kill them. . . There was no tribunal before which he had to account for his use [or abuse] of this authority." Ambrose Tighe, The Development of the Roman Constitution (New York: Appleton, 1889), 28-29; cf. Michel Humbert, Le remariage à Rome: Etude d'histoire juridique et sociale (Milan: Giuffrè, 1972), 135-138. See also Gaius Institutes, in Scott Civil Law 1:104; and Gellius Attic Nights 10.23.4-5 (2:279), for a description of the law. 
a daughter who could be given away by her paterfamilias. ${ }^{24}$ By all indications, marriage

cum manu appeared to have all the signs of an adoption or the transfer of property. A

wife seems to have been treated as an object that could be traded or negotiated away. ${ }^{25}$

The types of marriages practiced in pre-Imperial times are described by Gaius Assinius

Pollio, a first-century BCE Roman historian, orator, and poet. ${ }^{26}$

Levy describes how class distinction, patrician $^{27}$ or plebeian, ${ }^{28}$ defined which type of marriage one would enter into. ${ }^{29}$ To follow is an overview of the three main types of marriages and how divorce could be secured during Usus, coemptio, and confarreatio. ${ }^{30}$

\footnotetext{
${ }^{24}$ Gaius Institutes 1:137a, in Scott Civil Law 1:102. A trace of such practice may be seen in modern marriage ceremonies in which the father "gives away" the bride. It is not difficult even in this day and age to find some communities in Latin America where the "patriarch," meaning a grandfather or a father, decides when a son or daughter marries and/or divorces. A daughter-in-law is submissive to the husband through the "patriarch's" dictum.
}

${ }^{25}$ Table VI, Law I of the XII Tables states: "A father shall have the right of life and death over his son born in lawful marriage, and shall also have the power to render him independent, after he has been sold three times." The patria potestas (paternal authority) of a paterfamilias was protected by this law. S. P. Scott, commenting on his translation of this law, says: "This privilege enjoyed by Roman fathers was a relic of the patriarchal authority originally asserted by a man over his household, including ... slaves and other dependents, derived from ancient custom. It continued to exist after Rome had attained an exalted rank in the scale of civilization. . . . It is said by Justinian (code VI, 26) to have been an institution peculiar to the Romans; for while other nations possessed authority over their children unlimited by any legislative provision, few of their regulations bore even a distant resemblance to those which confirmed the Roman father in the exercise of his unquestioned and arbitrary power ... imposed on all the descendants through the son, but did not affect the off-spring of a daughter who was subject to the paterfamilias of the family into which she had married. ... It was not until $370[\mathrm{CE}]$ that measures were taken to place restrictions upon the irresponsible power of the head of the household." Agylaeus et al. Laws, in Scott Civil Law 1:6465. Also, see Dionysius Antiquities 2.26.1-6, 2.27.1-2 (1:387).

${ }^{26}$ See Gaius Institutes 1.111-125, 136-137a, in Scott Civil Law 1:97-99.

${ }^{27}$ Noble or aristocratic.

${ }^{28}$ Common or lower class. Mob mentality or behavior is referred to in Spanish as "la plebe."

${ }^{29}$ Livy (4.1-3) also describes the debate that considered doing away with class distinctions so that not only could plebeians become consuls, but also able to marry patricians. The law of the XII Tables, as described by Livy (4.4-5), prohibited such distinctions. Livius Livy (trans. Foster, LCL, 2:257-273). Bell asserts that it was not until imperial times when these three classes could be distinguished: Senatorial, equestrian, and plebeian. Bell, Exploring, 186-187.

${ }^{30}$ For a definition of these three terms, see each section, below. For a full description of these three forms of marriage, see Gaius Institutes 1.112, in Scott Civil Law 1:97. 


\section{Marriage by Usus}

Marriage by usus (literally, "abduction") is considered to be the most ancient of the three types of marriage known in pre-Imperial Rome. ${ }^{31}$ All the extant texts that mention the forms for acquiring manus mention usus first. This type of "marriage" (if this is what it may be called) was the ancient practice of abduction, sometimes forceful, at times consensual, as when a girl desired a certain young man whose gallantries her parents opposed. Usus, in essence, was a gateway to "legitimize" a union. ${ }^{32}$

It is possible that Rome tried to civilize this type of practice by allowing men to acquire manus once such abduction had taken place. In marriage by usus the husband acquired manus over his wife after twelve months of continuous cohabitation. ${ }^{33}$ Although historian-students of the classics as early as Karlowa, ${ }^{34}$ and as recent as Treggiari, ${ }^{35}$ contend that usus was a bonafide legal marriage, the language of Aulus Gellius, however, implies that usus was something less than marriage. ${ }^{36}$ Lévy-Bruhl calls it "a trial

\footnotetext{
${ }^{31}$ See John F. MacLennan, Primitive Marriage: An Inquiry into the Origin of the Form of Capture in Marriage Ceremonies (Chicago: University of Chicago Press, 1970), 7; Adhémar Esmein, Mélanges d'histoire du droit et de critique: Droit Romain (1886, repr. Aalen, Germany: Scientia Verlag, 1970), 9; Carl Wium Westrup, Quelques observations sur les origines du mariage para "usus" et du mariage sans "manus" dans l'ancien droit romain (Paris: Tenin, 1926), 34-35.

${ }^{32}$ Quite similar to Israelite practice according to Deut 22:28-29, "If a man meets a virgin who is not engaged, and seizes her and lies with her, and they are caught in the act, the man who lay with her shall give fifty shekels of silver to the young woman's father, and she shall become his wife." 97.

${ }^{33}$ The Law of the XII Tables, Table VI, Law V; Gaius Institutes 1:113, in Scott Civil Law 1:68,

${ }^{34}$ Before acquiring manus, Karlowa calls the union a "matrimonium non justum (juris gentium)." Should a wife not be able to avail herself of the trinoctium before the twelve months, her union became "matrimonium justum," Karlowa, Römische, 2:162-163.

${ }^{35}$ Treggiari, Roman Marriage, 288.

${ }^{36}$ See Gellius Attic Nights 3.2.13-14 (1:243).
} 
marriage." 37 The XII Tables state: "Where a woman who has not been united to a man in marriage lives with him for an entire year without the usucaption $^{38}$ of her being interrupted for three nights [trinoctium], she shall pass into his power as his legal wife."39 Furthermore, historians fail to mention whether there was any kind of declaration that honored the union, or how a wife could be distinguished from a concubine before manus could be acquired. ${ }^{40}$

Speaking of usus, Corbett asks: "Were they married or simply in de facto cohabitation? If they were legally man and wife, then it was marriage without manus [sine manus], and we are forced to admit the existence of free marriage prior to the XII Tables." Corbett concludes, and I agree, "usus then must be regarded not as a form of marriage, but solely as a way of acquiring manus."

It is difficult to see how binding this "marriage" was, or its purpose, since in a sine manu "marriage" the wife remained under the potestas (authority) of her paterfamilias. Because of the way this "marriage" was structured, divorce may have simply involved abandonment or expulsion from the home, since there is no history of

\footnotetext{
${ }^{37}$ Henri Lévy-Bruhl, "Les origines du mariage sine manu," Tijdschrift voor Rechtsgeschiedenis
} 14 (1936): 453.

${ }^{38}$ Refers to the manner in which property is acquired by the lapse of time, as required by law. See Glare, OLD, s.v. "Usucaption."

${ }^{39}$ The Laws of the XII Tables, Table VI, Law V. Emphasis supplied. Scott makes a pertinent comment when he says: "This indicates the existence of a woman as a mere chattel to be acquired by uninterrupted possession and use for one year, like any other species of personal property. . . . This kind of matrimonial union was the most common and popular one in the early days of Rome." Scott Civil Law, $1: 68$.

${ }^{40}$ For a fuller description, see Beryl Rawson, "Roman Concubinage and Other de Facto Marriages," in Transactions of the American Philological Association 104 (Cleveland, OH: Case Western University Press, 1974), 279-305. 1979), 86.

\footnotetext{
${ }^{41}$ Percy Elwood Corbett, Roman Law of Marriage (1930, repr., Aalen, Germany: Scientia Verlag,
} 
divorce occurring under $u s u s .{ }^{42}$ Now, if acquiring manus was the purpose of usus, why would coemptio (literally, "purchase") not be practiced? Perhaps usus was the only recourse a man had to have any hope of marrying his loved one. ${ }^{43}$ When $u$ sus (abduction) was not consensual, Watson believes that the woman used the trinoctium ("three-night interval") in which she refused cohabitation in order to avoid manus. If usus was a form to acquire marriage, then the trinoctium was its "divorce."

Perhaps Declareuil hits the mark as to why usus was not de facto a marriage. He ascertains that "the usurpatio trinoctii, ${ }^{44}$ the rule where usus could not procure manus over a woman without sui juris [one's legal guardians] and the agreements made with the paterfamilias of the others caused the entry of the wife into her husband's family more and more rare." $" 45$ Gaius summarizes the question by saying that usus had "been partly repealed by legal enactments, and partly abolished by disuse."46

That usus was not a legal marriage is seen in that in the first twelve months of living together such a "marriage" could exist sine manu (without the legal procedure for acquiring a woman). If the woman did not break the continuous cohabitation (trinoctii

\footnotetext{
${ }^{42}$ See Allan Watson, The Law of Persons in the Later Roman Republic (Oxford: Clarendon, 1967), 53.
}

${ }^{43}$ As was the practice (and still is in some rural areas) in Latin America, when the family rejects the advances of a young man towards their daughter/sister, the only recourse he has is to abduct her or to "elope" when their mutual affections are impeded by the father/family members. No longer being a virgin, her father feels compeled to marry his daughter to that young man in order to preserve the family's honor.

${ }^{44}$ The "three-night rule" was the rule in which the forcefully abducted woman was able to end the union should she be able to fend off the sexual advances of her abductor for three consecutive nights.

\footnotetext{
${ }^{45}$ Joseph Declareuil, Rome, the Law-Giver (New York: Alfred A. Knopf, 1927), 101-102.

${ }^{46}$ Gaius Institutes 1.111, in Scott Civil Law 1:97.
} 
rule) before the twelfth month, they could continue indefinitely in a "marriage" sine manu. ${ }^{47}$

The "jury" is still out as to whether usus was the popular form of "marriage" during the Republican period. What can be gleaned from the extant texts is that consensual usus could have served as a historical precedent to the free marriage system that eventually took hold in the Republic. Classical legal theorists surmise that consensual usus became more popular during Imperial times in view of changing standards in which women saw this type of union as a way to avoid subjugation of cum manu marriages and as a way to maintain some form of independence. "Marriage" by usus required no formal divorce whether separation was consensual or not.

Lévy-Bruhl suggests that Greek individualism influenced women to view marriage cum тапи as undesirable. Such influences, according to Lévy-Bruhl, were introduced at the end of the third century BCE, precisely at the point where the Roman women's movement began. ${ }^{48}$ (See "Women's Movement" below.)

The following points appear to be evident from my analysis:

1. Provisions for divorce existed under Roman law of an earlier period.

2. Such provisions may not have been necessarily followed.

\footnotetext{
${ }^{47}$ Lévy-Bruhl contends that the "marriage" by usus was unfavorable to the woman since it was used by the husband as a tool to repudiate his wife for infertility without any penalties. The wife remained in a state of uncertainty during the first twelve months, without the protection of manus. He considers that the trinoctium that favored the woman was a later development. Lévy-Bruhl, "Les origines," 453.

${ }^{48}$ Ibid., 460-462. Nevertheless, such "individuality" would not be Western-modern individuality in any sense. Where a woman married cum manu she was under the control of the cognati (relatives on the husband's side) family, sine manu or divorced women came back to the agnati (her father's household or his relatives) family. In the agnati family conception of agricultural societies, the extended family rules, not the individual. For more, see Jack Goody, The Development of the Family and Marriage in Europe (Cambridge: Cambridge University Press, 1983), 10-13. It must be recognized, however, that toward the
} 
3. Women appear to have been the victims of a male-oriented society.

4. As a result, abuses were very likely to have happened.

These last two points possibly set the stage for the "liberating" movement during the middle half of the second century $\mathrm{BCE}$, leading women to fight for and obtain a few rights, eventually, even the right to divorce their husbands.

\section{Marriage by Coemptio}

Marriage by coemptio (purchase) ${ }^{49}$ carries us back to another ancient form of human "marriage" custom. Abduction (usus) and purchase (coemptio) were the simplest means in acquiring a wife. ${ }^{50}$ Plebeians had been strangers to the religious marriage ceremony enjoyed by patricians (see "marriage by confarreatio," below) or any kind of legal marriages, for that matter. Servius Tullius's reforms ${ }^{51}$ introduced the plebeians to the marriage practice known as coemptio, which was intended to promote and advance marital equality as that held by the patricians. ${ }^{52}$

Although this type of marriage was not sacred in character, the XII Tables held that plebeian citizens could enjoy conubium (legal marriage status) in conformity with

end of the Republic, there was a trend away from the agnatic conception of the family. See Barry Nicholas, An Introduction to Roman Law (Oxford: Oxford University Press, 1962), 68-69.

${ }^{49}$ For Gaius's detailed description and practice of marriage by coemptio see his Institutes 1.113 , 119, 123, 137-137a, in Scott Civil Law 1:97-102.

${ }^{50}$ MacLennan, Primitive Marriage, 7-11.

${ }^{51}$ These reforms occurred prior to the XII Tables (451 BCE.). Launspach believes that the reforms were named after Servius Tullius, the sixth king of Rome (578-535 BCE), not that he enacted them. Charles W. L. Launspach, State and Family in Early Rome (London: Bell, 1908), 80-88, 110-128.

${ }^{52}$ See Plutarch Livy (Foster) 1.42-44 (1:147-153). James Muirhead, Law of Rome (London: A \& C Black, 1916), 32-34, and Tighe, Constitution, 59-66, however, believe that plebeian marriages never equaled those of the patricians in status or legal recognition. 
Civil Law. ${ }^{53}$ Such marriage, therefore, allowed men to acquire manus over their wives through coemptio (purchase). ${ }^{54}$ Gaius calls it an imaginaria vendito (symbolic sale). ${ }^{55}$

Five witnesses were required for the transaction to take place. Historians are not sure as to the kind of transaction involved in a coemptio ceremony, whether there was a real purchase made in bronze, or if the bridegroom simply paid the summus unus (a symbolic bronze coin) to the tutor (father or legal guardian) in exchange for the bride.

The "purchase" appears to be merely symbolic, since according to Jolowicz ${ }^{56}$ and Watson $^{57}$ bronze was weighed in scales until a fairly late date. The inferences by Gaius that each partner in the marriage bought one another has found resistance from historians, since the main purpose of coemptio was to establish manus, something a woman could never claim over a husband. ${ }^{58}$

Marriage by coemptio appears to have "tied the knot" rather loosely, however, since divorce was possible through a "loophole" Gaius describes as remancipatio ("to liberate again"). The price of "purchase" was simply returned, thus dissolving the cum

\footnotetext{
${ }^{53}$ See Gaius Institutes 1.113, in Scott Civil Law 1:97.

${ }^{54}$ The so-called "dowry" in many ancient (and in some $21^{\text {st }}$ century) societies, in which the father
} receives a payment for his daughter at her betrothal. In Judaism it came to be known as the Ketubah (see $m$. Ket 1.2-3).

${ }^{55}$ The particulars of the manner in which coemptio was accomplished are impossible to reconstruct. They come from late authors, and modern historical reconstructions are almost irreconcilable. For most of this section, I am indebted to G. MacCormack, "Coemptio and Marriage by Purchase," Bulletino dell'Istituto di Diritto Romano 81 (1978): 179-199; as well as Corbett, Roman Law, 78-81; and Muirhead, Law, 52-71, and the descriptions in Gaius Institutes 1.113-116, in Scott Civil Law 1:97-99.

${ }^{56}$ Herbert Felix Jolowicz, Historical Introduction to the Study of Roman Law (1932, repr., Holmes Beach, FL: Gaunt, 1996), 145.

${ }^{57}$ Alan Watson, Rome of the XII Tables (Princeton: University Press, 1975), 137.

${ }^{58}$ See Gaius Institutes 1.114, in Scott Civil Law 1:97. For more on this, see MacCormack, "Coemptio," 179-199; John Percy Vyvian Dacre Balsdon, Roman Women: Their History and Habits (Westport, CT: Greenwood, 1975), 179-180; and Muirhead, Law, 60-63. 
manu element of marriage. ${ }^{59}$ It was only until late in first century BCE that marriage by coemptio could be dissolved by quoad (a simple repudiation), ${ }^{60}$ when the free marriage system was in effect (see "free marriage" below).

\section{Marriage by Confarreatio}

Confarreatio $^{61}$ was the traditional patrician religious marriage ceremony. It involved the bride and bridegroom sharing a cake of spelt (panis farreus). Gaius, when he speaks of this form of marriage of the elite, mentions only this sacred marriage which he describes as the one conducted by the high priest of the state, the Pontifex Maximus, and the Priest of Jupiter, the Flamen Dialis, in the presence of ten witnesses. ${ }^{62}$ At this time the woman passed directly from the hand (manus) of her father or head of household (paterfamilias) to the household (paterfamilias) of her new husband. Dionysius of

Halicarnassus defines marriage by confarreatio in this manner:

The ancient Romans designated holy and lawful marriages by the term "farreate," from the sharing of far [or "spelt," a coarse variety of wheat] [sic] which we call zea; for this was the ancient and, for a long time, the ordinary food of all the Romans, and their country produces an abundance of excellent spelt. . . The participation of the wives with their husbands in this holiest and first food and their union with them founded on the sharing of all their fortunes took its name [confarreatio] from this sharing of the spelt and forged the compelling bond of an indissoluble union, and there was nothing that could annul these marriages. ${ }^{63}$

${ }^{59}$ See Justinian Digest 60.3.80, in Scott Civil Law 10:204.

${ }^{60}$ See Gaius Institutes $1.137 \mathrm{a}$, in Scott Civil Law 1:102.

${ }^{61}$ Literally, "with far." For a complete description see Dionysius of Halicarnassus's definition, below.

${ }^{62}$ Gaius Institutes 1.112, in Scott Civil Law 1:97.

${ }^{63}$ Dionysius Antiquities 2.25.2-3 (1:383). By Tacitus's time (late first century BCE to early second century CE) marriage by confarreatio was on its way to extinction. For a detailed view, see Corbett, Roman Law, 68-106. Although Dionysius asserts that under Romulus, marriage by confarreatio was indissoluble, he also describes when divorce (diffarreatio) could take place. Aulus Gellius contends that the indissolubility of a confarreatio marriage affected only one of the four highest priesthoods, the 
The Romans considered that marriage ensured the rearing of sons who might perpetuate the house and keep the paterfamilias strong. ${ }^{64}$ The Roman family was governed by fas ${ }^{65}$ and jus. ${ }^{66}$ For the patrician citizen, if his marriage was to be reckoned a lawful marriage (justa nuptiae), he had to wed another (non-blood relative) patrician. ${ }^{67}$ Tacitus $^{68}$ and Aulus Gellius ${ }^{69}$ add other details connected to marriage by confarreatio.

On the surface, marriage by confarreatio was noble and praiseworthy. It was supposed to last forever! Dionysius of Halicarnassus, a confessed admirer of Romulus, though admittedly found Romulus's laws harsh by necessity, praises the law of marriage as "wise," since, supposedly, it was this law that prevented divorces for over 500 years:

This law obliged both the married women, as having no other refuge, to conform themselves entirely to the temper of their husbands, and the husbands rule their wives as necessary and inseparable possessions. Accordingly, if a wife was virtuous and in all things obedient to her husband, she was mistress of the house to the same degree as her husband was master of it. . . But if she did any wrong, the injured party [husband] was her judge and determined the degree of

Flamen Dialis; and that death alone could break this marriage. If the wife died, he had at once to resign his priesthood. Gellius Attic Nights 10.15.23-25 (2:253). It was not until Domitian when the Flamen Dialis was permitted to divorce his wife. Plutarch describes the procedure in his Questions 50, in Moralia 4:83.

${ }^{64}$ For a thorough coverage of the Roman family, see Muirhead, Law, 14-20, 28-29; and Declareuil, Rome, 93-151.

65"Divine law and the will of the gods." Civil ceremonies during the royal years were meaningless without the approval of the gods; see Livius, Livy (Foster), 1.32 (1:112-119). By the fourth century BCE, however, though fas continued to influence the lives of the citizens, it had ceased to influence the law (of the XII Tables). See for example, Dionysius, Antiquities, 2.10 (1:340-343).

66"Human law or the dispensing of justice" from the legal point of view as encoded in the XII Tables. See for example the opening lines of the Enactments (1.1): "Justice [jus] is the constant and perpetual desire to give to each one that which he is entitled." Scott, Civil Law, 2:5.

${ }^{67}$ Marriage between blood relatives (first cousins) was permitted for centuries until Justinian abolished it; see Enactments 1.10.4, in Scott Civil Law 2:15. According to Muirhead, patricians and plebeians were allowed to intermarry by the Canuleian law of 445 BCE; see Muirhead, Law, 24. Corbett, however, disputes such assertion since marriage by confarreatio was a religious ceremony open only to patricians and the priestly offices up to the first century CE. See Corbett, Roman Law, 76.

${ }^{68}$ Tacitus Annals 4.16 (4:31-32).

${ }^{69}$ Gellius Attic Nights 10.15.1-32 (2:248-253), second century CE. 
punishment. Other offences [sic], however, were judged by her relations [sic] together with her husband; among them was adultery, or where it was found she had drunk wine. ... For Romulus permitted them to punish both these acts with death, as being the gravest offences [sic] women could be guilty of. . . . Both of these offences $[\mathrm{sic}]$ continued for a long time to be punished by the Romans with merciless severity.

Nevertheless, during Imperial times, marriage by confarreatio began to wane. ${ }^{71}$

Divorce (diffarreatio, literally, "the undoing of the far" or spelt) was possible, though not easily accessible. ${ }^{72}$ Tacitus states that "the system was old-fashioned, nor was there now the requisite supply of candidates, since the habit of marrying by the ancient ritual had been dropped, or was retained in few families." ${ }^{, 73}$ Mostly the flamines (the religious order) married by confarreatio at this time. Perhaps this may explain why only the flamines were forbidden to divorce. ${ }^{74}$

Because this type of marriage involved manus, marriage could not be dissolved on the whims of the husband. ${ }^{75}$ The XII Tables state, "If a husband desires to divorce his wife, and dissolve his marriage, he must give a reason for doing so." ${ }^{76}$ Dionysius of Halicarnassus ${ }^{77}$ is cited by supporters of the existence of a so-called "concilium

${ }^{70}$ Dionysius Antiquities 2.25.4, 6-7 (1:383).

${ }^{71}$ See Humbert, Remariage, 278-280.

${ }^{72}$ See Gaius Institutes 1.112-113, in Scott Civil Law 1:97; Ulpian Rules of Ulpian 9.1, in Scott Civil Law 1:231; Tacitus Annals 4.16 (3:30-33).

${ }^{73}$ Tacitus Annals 4.16 (3:31). Watson supports Tacitus's views on confarreatio as having been discarded by the second century BCE based on statements such as this. By all indications, though in a limited way, as stated by Tacitus above, confarreatio marriages were still alive in the middle of the first century CE.

${ }^{74}$ See Gellius Attic Nights 10.15.22 (2:253).

${ }^{75}$ See Plutarch Romulus 22.4, in Lives 1:163.

${ }^{76}$ The Laws of the XII Tables, Table VI, Law X, in Scott Civil Law 1:69.

${ }^{77}$ See Dionysius Antiquities 2.25 (1:383). 
domesticum" to which those contemplating a divorce must summon before effectuating a divorce. Halicarnassus writes that Lucius Annius was expelled from the senate for

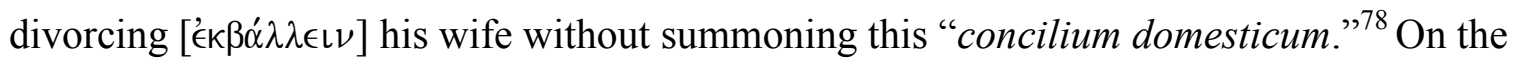
other hand, when Cicero speaks of divorce, he refers to the Law of the XII Tables as stipulating that the husband took back the household keys from his wife (supposedly entrusted to her at marriage) and through this act divorce was effected. ${ }^{79}$

Balsdon argues that the use of the divorce formula "Res tuas tibi habeto" ("take your things and go"), contained in the XII Tables, dissolved the marriage. ${ }^{80}$ Muirhead rightly concludes that "a procedure so simple could hardly apply where marriage had been contracted by confarreatio (or coemptio)" since manus was not easily dissolved. ${ }^{81}$

\section{Women's Movement of the Late Republic}

As in every period and culture, it is a matter of time and timing for any oppressed group to rise up and begin to demand its rights. In this particular case, it was the women's turn. About 150 years prior to Augustus's leges novae (new laws), women began to assert

\footnotetext{
${ }^{78}$ See Muirhead, Law, 107. Corbett doubts that such "amicorum concilium" (his term for concilium domesticum) ever existed, and that such family council is constructed from scant data. See Corbett, Roman Law, 226-227. For an extensive view on the so-called "family council," see Esmein, Mélanges, 23; cf. Paul Frédéric Girard, Mélanges de droit Romain (Paris: I. Larose \& L. Tenin, 1923), 370.

${ }^{79}$ See Cicero Philippics 2.28.70 (trans. Ker, LCL, 133). Interestingly enough, the extant text of the XII Tables does not contain such stipulation.

${ }^{80}$ Balsdon, Roman Women, 216. Such formula, though not found in the extant text of the XII Tables, must have been part of it at one point or another, since it is quoted and alluded to by many authors. For a retracing of its roots, see Allan Watson, "The Divorce of Carvilius Ruga," Tijdschrift voor rechsgeschiedenis 33 (1965): 33-41. The phrase, Tibi habeas res tuas ("keep your things and return to me mine [things]"), is found in Plautus's Latin adaptation of the Greek play, "Amphitryon," written between 204 and 184 BCE Plautus's use of the phrase comes with a twist: The words were uttered not by the husband (Amphitryon) but by his wife (Alcmena) in anger for his false accusations of infidelity. It does not seem from the text that a divorce ever occurred. Plautus, "Amphitryon," 928, Plautus (trans. Nixon, LCL, $1: 97)$.

${ }^{81}$ Muirhead, Law, 107.
} 
themselves and gain leverage through active demonstrations. During that time, because of the social structure supported by laws such as the patria potestas, the concept of the family (paterfamilias), and the cum manu condition of Roman women in marriage, they could never have claimed nor did they seem to have tried to claim an equal footing with men. A segment of society, however, can only endure oppression for a limited time. In time, women found the means to make their influence felt directly and effectively when their few basic rights were being violated. Early in the second century BCE, a grass-roots women's movement was born. ${ }^{82}$

In 215 BCE the Oppian law was enacted after Rome was defeated by Hannibal. It was an emergency measure which limited women's use of expensive goods due to the circumstances of war. They were forbidden to own more than a half an ounce of gold, to wear a parti-colored dress (purple), or to ride in a chariot within the city. ${ }^{83}$ Women seemed to have accepted their lot under the circumstances. Thirteen years later (202 $\mathrm{BCE}$ ), Rome defeated Hannibal. With the war over and prosperity slowly returning, women wanted some of the luxuries they had previously enjoyed. ${ }^{84}$

Livy reports an upheaval of a political magnitude with tremendous social implications. Women's push for the repeal of the Oppian law in 195 BCE produced an

\footnotetext{
${ }^{82}$ For a view of this truly revolutionary female movement, see Elaine Fantham, Julia August: The Emperor's Daughter: Women in the Ancient World (New York: Routledge, 2006), 73-75; cf. Larissa Bonfante Warren, "The Women of Etruria," in John Peradotto and J. P. Sullivan, eds., Women in the Ancient World: The Arethusa Papers (Albany: State University of New York Press, 1984), 229-239; Judith P. Hallet, "The Role of Women in Elegy: Counter-Cultural Feminism," in Women in the Ancient World: The Arethusa Papers, ed. John Peradotto and J. P. Sullivan (Albany: State University of New York Press, 1984), 241-262; and Mary R. Lefkowitz and Maureen B. Fant, Women in Greece and Rome (Baltimore: Johns Hopkins University Press, 1982), 176-180; Balsdon, Roman Women, 45-62.

${ }^{83}$ See Livius Livy 34.1.3-4 (trans. Sage, LCL, 9:413).

${ }^{84}$ For more on this, see Frank Frost Abbot, Society and Politics in Ancient Rome (New York: Scribner, 1918), 41-76.
} 
avalanche (granted, a very slow moving one) of reforms and concessions which would eventually, one hundred years down the line, grant women the most basic of human rights: self-determination. Livy reports that the ladies came out in droves. They "could not be kept at home by advice or modesty or their husbands' orders, but blocked all the streets and approach to the forum ... begging the men to have their distinctions restored. ${ }^{185}$ Two consuls, Marcus Fundanius and Lucius Valerius, came forward in support of the women. Marcus Porcius Cato (the Elder), the Censor and defender of the law, turns to the consuls and the tribunes, apparently in a public open forum, in a fuming diatribe against this "women's lib" movement:

I do not know, I say, whether this madness is more shameful for you, tribunes, or for the consuls: for you, if you have brought these women here to support tribunicial seditions; for us, if we accept laws given us by a secession of women, as formerly by a secession of plebeians. ... If they win in this, what will they not attempt? Review all the laws with which your forefathers restrained their licence $[\mathrm{sic}]$ and made them subject to their husbands; even with all these bonds you can scarcely control them. ... If you suffer them to seize these bonds one by one and wrench themselves free and finally to be placed on parity with their husbands, do you not think that you will be unable to endure them? The moment they begin to be your equals, they will be your superiors. ${ }^{86}$

Cato now turns to the women and rants:

What sort of practice is this of running out into the streets and blocking the roads and speaking to other women's husbands? Could you not have made the same requests, each of your own husband, at home? ${ }^{87}$ Or are you more attractive outside and to other women's husbands than to your own? ${ }^{88}$

Next he turns to the consuls and tribunes in a tirade, which said in part:

${ }^{85}$ Livius Livy (Sage) 34.1.5-6 (9:413).

${ }^{86}$ Ibid., 34.2.6-9a, 34.3.1-2 (9:417-419).

${ }^{87}$ Rings quite similar to the Pauline injunction in 1 Cor $14: 35$, "If there is anything they desire to know, let them ask their husbands at home. For it is shameful for a woman to speak in church."

${ }^{88}$ Livius Livy (Sage) 34.2.9b-12a (9:415). 
Our ancestors permitted no woman to conduct even personal business without a guardian to intervene on her behalf; they wish them to be under the control of fathers, brothers, husbands; we (heaven help us!) [sic] allow them now even to interfere in public affairs. ... What else are they doing now on the streets and at the corners? .. . Give loose reign to their uncontrollable nature and to this untamed creature and expect that they will themselves set bounds to their licence $[\mathrm{sic}]$; unless you act, this is the least of the things enjoined upon women by custom or law. ${ }^{89}$

Whether it was the effects of Lucius Valerius's powerful speech, or that the speech may have helped to tip the balance in their favor, as Livy reports, the law was repealed. $^{90}$

From the middle of the second century BCE until the end of the Republic and early empire, any laws that attempted to limit women's rights failed. In fact, if women's lot improved, it was borne out of public sentiment which viewed a woman's condition under manus as one without control of her own life. It was a matter of time for the conception of marriage, upon which these practices rested, that would eventually bring about change.

When Augustus felt it necessary to allow women to divorce their husbands, it grew from the theory that marriage was a contract which, like all other contracts, required the free consent of the two people involved and could be dissolved if they (the women) wished it. ${ }^{91}$ As in other partnerships, the two contracting parties stood on an equal footing. The wife controlled her property and willed it as she pleased. Even women

\footnotetext{
${ }^{89}$ Ibid 34.2.12b-14; 9:415-417.

${ }^{90}$ For a complete account of the speeches, see Livius Livy (Sage) 34.5-8 (9:427-441).

${ }^{91}$ Justinian Digest 35.1.15, in Scott Civil Law 7:303.
} 
married under manus could dissolve their marriages and secure a guardian of their own choice and through him manage their fortune as they pleased. ${ }^{92}$

\section{Marriage and Divorce during Imperial Times}

During Republican times there were no divorce courts. As noted above, any divorce was carried out under the stipulations of cum manu marriages and always initiated by the husband. By the end of the Republic, however, no settled form seems to be required for the dissolution of marriage. Divorces were accomplished without any formalities. A man was allowed to kill a wife if caught in adultery, or divorce her and retain a portion of her dowry if he believed she was being unfaithful. ${ }^{93}$ The wife, on the other hand, might want to divorce him, but if she was married cum manu she could not take any legal action against the husband, even if she caught him in adultery. ${ }^{94}$ To the unfairness of such a practice, Plutarch writes: "A husband who bars his wife from the pleasures in which he himself indulges is like a man who surrenders to the enemy and tells his wife to go on fighting." $" 95$ Women began to rebel against the servitude of the cum manu marriage, and as noted above, as the "traditional" forms of marriage began to decline, the upsurge of free marriage eventually became the norm.

Augustus passed the Lex Julia de Adulterii between 18 and 16 BCE. It was his way to counter the moral corruption into which the upper echelons of Roman society had

\footnotetext{
${ }^{92}$ For an account of rights won by women, see Livius Livy (Sage) 34.4-7 (9:425-439).

${ }^{93}$ Dionysius Antiquities 2.25 .6 (1:385).

${ }^{94}$ Gellius Attic Nights 10.23 .5 (2:279).

${ }^{95}$ Plutarch Moralia 145; cf. Balsdon, Roman Women, 219-221.
} 
sunk, as well as a political tool to court the more conservative-minded plebeians. ${ }^{96}$ The law was created to deal not only with adultery, but with a larger body of general corruption, social and moral. So, rather than seeing Augustus's reforms as liberalizing the system by opening the door for women to initiate and obtain divorces, he was in fact trying to hold in check a society which was no longer governed by any laws.

\section{Free Marriage and Concubinage}

A free or consensual marriage, that is, marriage sine manu, was theoretically in practice at Rome as early as the XII Tables (see "marriage by usus," above). A consensual arrangement to live together apparently became the common practice in the third and second centuries BCE. ${ }^{97}$ Unlike $u s u s$, where cohabitation for at least twelve months brought some kind of permanency to the relationship, concubinage is difficult to differentiate from marriage in extant sources.

When it comes to the free or consensual "marriage," it appears to be of a different kind altogether. With the Augustan legislation the practices of marriage and divorce suffered enormous alterations that lasted until the waning years of the Empire. The old idea of a binding contract in the sponsalia (betrothal) was no longer present. ${ }^{98}$ Classical law stated that "a marriage cannot take place unless all the parties consent, that is to say

\footnotetext{
${ }^{96}$ See Abbot, Society and Politics, 41-76.

${ }^{97}$ For a summary of the evidence, see Corbett, Roman Law, 91.

${ }^{98}$ See Gellius Attic Nights 4.4 .2 (1:325).
} 
those who are [to be] united, as well as those under whose authority [paterfamilias] they are." $^{99}$

In theory, consent of the father was enforced when both contracting parties were subject to him. ${ }^{100}$ Nevertheless, in the event a son or a daughter dissented with a father's choice, the law intervened in the best interest of the prospective couple, even if they still were subject to their fathers. ${ }^{101}$ Aulus Gellius carries on a philosophical dialogue about the extent a child must submit to the authority of a father: "It is a frequent subject of discussion with philosophers, whether a father should always be obeyed, whatever the nature of his commands," he quips. He proposes three scenarios:

1. "That all a father's commands must be obeyed."

2. "In some he is to be obeyed, in others not."

3. "It is not necessary to yield to and obey one's father in anything."

Gellius discards the first and the third scenarios. If a command is dishonorable, a father should be disobeyed in things such as "treason to one's country, a mother's murder," and even these must be declined "gently and respectfully." If a command is

\footnotetext{
${ }^{99}$ Justinian Digest 23.2.2, in Scott Civil Law 5:244. There are those who question the extent of consent the contracting bride and groom would have. Recent demographic studies based on sepulchral inscriptions point to puberty-age Roman girls at marriage during the late Republic compared to the older age of the men. See Treggiari, Roman Marriage, 293; cf. M. K. Hopkins, "The Age of Roman Girls," Population Studies 18 (1965): 309-327; and Richard P. Saller, "Men's Age at Marriage and Its Consequences in the Roman Family," Classical Philology 82 (1987): 179-199.

${ }^{100}$ Ulpian Rules 5.2, in Scott Civil Law 1:227.

${ }^{101}$ Parents could not force a son to marry against his will (Justinian Digest 23.2.21, in Scott Civil Law 5:248), nor to divorce against his will (Justinian Digest 24.1.32.19, in Scott Civil Law 5:325). A daughter was allowed to dissent from her father if he chose a man who was morally unworthy or shameful (Justinian Digest 23.1.12, in Scott 5:242); and if she refused to enter the bed chamber of the man whom her parents consented to marry, she would not become his wife, since it was "consent, not cohabitation" that made them husband and wife (Justinian Digest 35.1.15, in Scott Civil Law 7:303).
} 
honorable, a father must be obeyed in such things as "keeping faith, defending one's country, loving one's friend." 102

Gellius then describes those things which the Greeks considered neutral or even indifferent where a father is to be obeyed: "going to war, tilling the fields, seeking office, marrying a wife." "But if a father should order his son to marry a woman of ill repute, infamous, and criminal," such act would cease to be "indifferent" or "neutral," therefore "ought not to be obeyed." Such law also applied to a daughter. ${ }^{103}$

What distinguished free marriage from a mere concubinage was the so-called affectio maritalis (a loving relationship). Until they had begun to regard each other in that light, they were not considered "married."104 There is no record of whether any official certificate was drawn up. Declareuil surmises that "proof" of their marriage (should a couple fake affectio maritalis) could be furnished through dotal (dowry-related) records and the memory of the religious celebration. ${ }^{105}$

Under the free marriage system, which was becoming the normal practice in the waning years of the late Republic, a wife or her father acting on her behalf, could divorce her husband as easily as a husband could divorce his wife. ${ }^{106}$ Fowler captured the reality

${ }^{102}$ Gellius Attic Nights 2.7.1-21 (1:142-147).

${ }^{103}$ See Susan Treggiari, "Consent to Roman Marriage: Some Aspects of Law and Reality," Échos du monde classique 36 (1982): 34-44.

${ }^{104}$ If the woman was used only for pleasure, it was concubinage, not marriage. Paulus Opinions, 2.20.1, in Scott Civil Law 1:277; Justinian Digest 25.7.4, in Scott Civil Law 6:50.

${ }^{105}$ Declareuil, Rome, 103. There is no way to verify Declareuil's assertions, mainly because there was no religious ceremony involved in free marriage, and there is no evidence that written records were kept in drawing up the dowry.

${ }^{106}$ Justinian Digest 24.2.7, in Scott Civil Law 5:336; Justinian Digest 25.2.11, in Scott Civil Law 6:32. Interestingly enough, Plautus (born $255 \mathrm{BCE}$ ), in his comedies, alludes to divorces initiated by the wife at a much earlier period. See for example Plautus "Braggart Warrior” Plautus 1164-1167, 1277-1278 
of the free marriage practices this way: "We may be sure that the idea of the marriage was not that of a union for love, though it was distinguished from concubinage by an affectio maritalis as well as by legal forms." 107 The powerful force behind it was "the idea of the service of the family and the state that lay at the root of the union."108

As the Republican era came to a close, the free marriage system was producing divorces for the most trivial reasons. In the highest classes of society they were a matter of political manipulations and intrigue. ${ }^{109}$ When the Republic collapsed, the whole question of divorce invited the attention of Augustus. The historian Tacitus is quite colorful in his description. ${ }^{110}$ Augustus saw divorce become rampant, ${ }^{111}$ if in fact what was being practiced could be called "divorce." It appears that desertion, rather than divorce proper, was the norm.

Augustus enacted laws to have his objects devise some satisfactory proof that a divorce had in fact taken place, rather than mere abandonment by either party. ${ }^{112} \mathrm{He}$ made forceful abduction or crimes of sexual violence (stuprum) a crime actionable before a special court through the Lex Julia de Adulteriis $18 \mathrm{BCE}$; and to prevent connivance in

(trans. Nixon, 3:248-249, 262-263); Plantus “Rudens” Plautus 1046-1047 (trans. Nixon, 3:390-391); and Plautus “The Two Menaechmuses” Plautus 722-723 (trans. Nixon, 2:438-439). For the original Latin version, see Plautus T. Macci Plavti Comoediae (trans. Lindsay). 141.

${ }^{107}$ William Warde Fowler, Social Life at Rome (Chautauqua, NY: The Chautauqua Press, 1909),

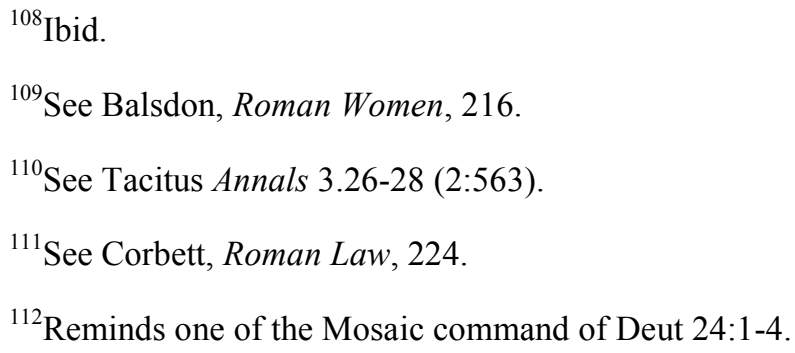


a wife's adultery on a husband's part, he encouraged the participation of public informers who also did the part of a public prosecutor. ${ }^{113}$

Augustus's legislation introduced a formal procedure, recognizable in law, for the notification of divorce. By the new law a married man was liable to prosecution if he seduced (literally, “violated") another man's wife (stuprum), or if he had a mistress who was not a registered prostitute. ${ }^{114}$ Some married women "ran around" with married men by registering as prostitutes. The senate, however, closed this loophole. ${ }^{115}$ For centuries Stoicism had deplored the freedom enjoyed by the husband. Leading Stoics of the first century CE such as Musonius Rufus and Lucius Anaeus Cornotus (the latter banished from Rome by Nero) deplored the state of things. ${ }^{116}$

There were also classes of people in the Empire-Jews and Christians - for instance, whose religious code imposed upon people a far higher standard of moral conduct than the public law enforced, calling husbands and wives to mutual submission (see Eph 5:21-25) and used as a tool to counter the Roman ethic.

\section{Fictitious Marriages}

Fictitious marriages appear to be widespread during Imperial times. Extant sources tell us that its only object was to cheat the law. A fictitious marriage is defined as a couple entering into a marriage with no intention on either side to live together as

\footnotetext{
${ }^{113}$ Tacitus Annals 11.35 (2:67). Also Martial Epigrams 10.69 (trans. Bailey, LCL, 2:387).

${ }^{114}$ See Balsdon, Roman Women, 217-220; cf. Corbett, Roman Law, 228-234.

${ }^{115}$ See Tacitus Annals 2.85.1.

${ }^{116}$ Catullus Catullus (trans. Goold, LCL, 61, 11).
} 
husband and wife. ${ }^{117}$ Seneca recounts how poor men entered "marriage" for a fee, so as to allow the woman to escape the penalties against celibacy imposed on those who were above and below a certain age. ${ }^{118}$ Quintus entered into such an arrangement and Martial chides him: "Quintus, you call Laelia, who married you on account of the law, your lawful wife?"119

It seems that it was no problem for "high heeled" women of the Empire to enter into bogus marriages, as Suetonius reports, even if they were married to the Emperor, as was Claudius's wife, Messalina. She married the commoner Silius. "The marriage was a feigned one," writes Suetonius. ${ }^{120}$ Evidently this was not the only time she did this. Cassius Dio states that she went through farcical marriage ceremonies conceiving "a desire to have many husbands, that is, men really bearing that title [of husband]."

\section{The Age of Marriage}

When one considers the precariousness of the marriage bond under "normal" circumstances, how secure could a marriage be in a society where marriage is based on

${ }^{117}$ Gellius Attic Nights 1.6.1-8 (1:31).

${ }^{118}$ For a broader view of this practice as reported by Seneca, see Walther Grossgerge, "Perigamon," in De Senecae et Theosphrasti libris de matrimonio (Regimonti: Ex Officina Kuemmeliana, 1911), 55-63.

${ }^{119}$ Martial Epigrams 5.75 (1:419). For Laeila’s other commending “qualities,” see Martial Epigrams 10.68 (2:387).

${ }^{120}$ Suetonius Deified Claudius 29.3, in Suetonius (trans. Rolfe, LCL, 2:59); also, see Juvenal Satires 6.114-132, in Juvenalis and Persius Juvenal and Persius (trans. Ramsay, LCL, 93; and Seneca Octavia 260, in Seneca's Tragedies (trans. Miller, LCL, 2:431.

${ }^{121}$ Dio Roman History 60.31 .2 (trans. Earnest Cary, LCL, 8:11). 
no more than the consent of "a man and a woman,", 22 one of whom had to be at least seven years of age, ${ }^{123}$ and at least twelve before being able to formally become someone's wife? ${ }^{124}$

Cicero tells us that he betrothed his daughter Tullia to Calpurnius Piso Frugi early in $66 \mathrm{BCE}$. The marriage took place in $63 \mathrm{BCE}$. Tullia was born in $76 \mathrm{BCE}$, making her ten years of age at the time of her betrothal and thirteen at marriage. ${ }^{125}$ This was probably typical, and it seems that the matter was entirely a "mariage de convenance," as was the practice in many ancient societies. ${ }^{126}$

\section{The Decaying Status of Marriage Relationships}

If we are to accept the veracity of ancient records (they appear to be true given the ubiquitous nature of the accounts), the levels of morality in the first century BCE seem to be quite low. The Elder Cato's view, “All other men rule their wives, we [Romans] rule other men, and our wives rule us," ${ }^{127}$ could not have been truer at this time. It seemed that neither law nor tradition was able to produce any effect on the moral state of Rome as the first century CE approaches. Yet it is clear enough from Plutarch's Life of Cato that the

\footnotetext{
${ }^{122}$ The law stated: "Marriage is the union of a man and a woman, forming an association during their entire lives, and involving the common enjoyment of divine and human privileges." See Justinian Digest 23.2.1, in Scott Civil Law 5:244; and Justinian Enactments 1.9.1, in Scott Civil Law 2:13.

${ }^{123}$ See Justinian Digest 23.1.14, in Scott Civil Law 5:242. The husband had to be at least fourteen. See Ulpian Rules 11.28, in Scott Civil Law 1:234.

${ }^{124}$ The law stated that she could marry before the age of twelve, yet she did not become a "lawful wife" until she reached the age of twelve. See Justinian Digest 23.2.4, in Scott Civil Law 5:245.

${ }^{125}$ See Cicero Letters to Atticus 8.3 (trans. Bailey, LCL, 1:45).

${ }^{126}$ For a point-by-point explanation in regard to the age of marriage in different cultures and in different periods, see Edward Westermarck, The History of Human Marriage (London: Macmilllan, 1921), 1:337-394.

${ }^{127}$ Plutarch Cato the Elder 8.2, in Lives 2:323.
} 
view on conjugal relations was "a coarse one." ${ }^{128}$ A wife was looked upon as a necessary agent for providing the state with children rather than the "help-meet" and the object of the husband's care and love. Women divorced by their husbands in the last two centuries BCE appear to be the victims of their husbands' callousness rather than of the women's own shortcomings.

One must admit, however, that some women were rather difficult to live with, such as the wife of Quintus, Cicero's brother, who seemed to have had quite a temper. ${ }^{129}$ Other women found that they could not realize their ambitions as married women. Some women married, played fast and loose with the married state, and neglected their children, if present. Two or more "divorces" were not uncommon. ${ }^{130}$

Such was the state of "married" life in the first century BCE that Augustus found to be one of his most difficult struggles. He exiled Ovid (43 BCE to $18 \mathrm{CE}$ ) for publishing a poem in which he exults the products of a society which looks on "pleasure, not reason or duty, as the main end of life; the gratification of one's own wish for enjoyment and excitement, without a thought of the misery all around."131

Yet, no amount of reform seemed to hold in check the bizarre behavior of the Romans. During Nero’s reign, Sempronius Gracchus, a patrician, was formally married

${ }^{128}$ Ibid.

${ }^{129}$ Cicero Letters to Atticus 5.1 (trans. Winstedt, LCL, 337-341).

${ }^{130}$ See Scullard, History, 115-117.

${ }^{131}$ Ovid Ars Amatoria 1.31-34, in Ovid Art of Love (trans. Mozley, LCL, 79); cf. Fowler, Social Life, 147-154. 
by paying a dowry of 400,000 sesterces. ${ }^{132}$ The consort was a young boy! ${ }^{133}$ But what could one expect from the general population in terms of morality? When Nero became Emperor, he himself married a young man in a formal marriage ceremony. What seems shocking is that Nero was wearing the veil of the bride. ${ }^{134}$

\section{Long Absences of Husbands}

In estimating the changed position of women within the family, we must not forget the fact the in the course of the long and unceasing wars of the second and first centuries BCE, husbands were away from home for years, with no word whether they lived or perished in combat, by disease, had fallen into the hands of an enemy, or become enslaved. $^{135}$

One of the realities of life which came with the Roman Empire and deeply affected the lives of women was when the man's career lay in public service. With their foreign assignments women were no longer compelled to remain in Rome during their husbands' tours of duty. Women had fled overseas with their husbands during the civil wars $^{136}$ and, after that the wisdom of the Republican rule was challenged.

\footnotetext{
"Sesterce."

${ }^{132}$ A small silver coin issued sporadically during the Roman Republic. See Glare, $O L D$, s.v.

${ }^{133}$ Juvenal Satires 2:117-148; cf. ibid., 27-29, 173-175, 183-210.

${ }^{134}$ Tacitus Annals 15.37.8-11; Tacitus Histories 4:269-271; cf. Suetonius "Nero XXVIII" 1 Suetonius 2:131-133.

${ }^{135}$ See Fowler, Social Life, 147-148.

${ }^{136}$ Gellius Attic Nights 10.3 .3 (2:240-242).
} 
The regulations during Republican times were changed during Imperial times. ${ }^{137}$ Cicero believed this was due to the behavior of a few prominent wives' tantrums. ${ }^{138}$ In a man's public career there might be more than three occasions when he had to leave Rome to spend at least a year or two in administrative or military duties in one of the provinces; and during these periods his family was broken up. Cicero's letters to Atticus recount some of the tragedies brought about by those family separations. ${ }^{139}$

More seriously still were the disasters which might occur where the "widow," if an attractive lady, became the prey of an accomplished seducer. Lurid accounts of her misbehavior, sometimes true, sometimes not, trickled out to her husband at his posting. When he returned home, his first act often was to divorce his wife. ${ }^{140}$ Also, there are grounds for believing that from the early Republic the prolonged absence of a husband, a wife at home, ignorant as to her husband's whereabouts, justified her remarriage without the need of a divorce. ${ }^{141}$

The issue was even more complex during classical law when, for instance, an official serving overseas was held captive; and especially when the captive was held as a slave, a marriage was annulled. There was no legal matrimony with a slave; therefore, it automatically dissolved the marriage. This was also applicable to a person convicted of a

\footnotetext{
${ }^{137}$ Balsdon, Roman Women, 59.

${ }^{138}$ See Gellius Attic Nights 10.3.3.

${ }^{139}$ Cicero Letters to Atticus 6.3.8.

${ }^{140}$ Many such accounts may be traced to extant first-century sources such as Plutarch Lucullus, 38.1, in Lives; Cicero Letters to Atticus 1.12-13; Dio Roman History 37.49.3; Suetonius Lives of Divine Julius 50.1; also, see Balsdon, Roman Women, 59.

${ }^{141}$ See Lévy-Bruhl, "Les origines," 155; cf. Corbett, Roman Law, 210-217.
} 
criminal act. An imprisoned convict was considered civilly dead; at this point, he ceased to be married in the Roman legal sense. ${ }^{142}$

\section{Unhappy Marriages}

The jealous husband kept his wife at home like a prisoner; she was a clausa puella (an imprisoned young woman), and the slaves of the house were her wardens. ${ }^{143}$ But slaves, for a favor or a price, might be persuaded to open doors and to carry love letters producing the phrase: "Quis custodiet ipsos custodes?" (Who will keep guard of the guards?). ${ }^{144}$

Men like Aemilius Paullus, considered virtuous and an otherwise model paterfamilias, divorced his wife. His friends criticized him because his wife was sensible, rich, and lovely. In reply he stretched out his legs and said:

A woman might be excellent in the eyes of her neighbors, but only the husband can tell where the shoe pinches. So it is a mistake for a woman to rely on her wealth, her breeding and her looks; she should think more of the qualities which affect her husband's life, of those traits of character which make for the harmony in domestic relationships. Instead of being impassive or irritating in everyday life, she must be sympathetic, inoffensive and affectionate. Doctors will tell you that they are not nearly as much alarmed by a very high temperature whose cause is evident as they are by one which rises steadily and whose cause they cannot diagnose. In the same way it is a succession of small inconspicuous pin-pricks and irritations, occurring day after day between a man and his wife which destroys their marriage and makes it impossible for them to go on living together. ${ }^{145}$

${ }^{142}$ Justinian Codex 5.17.1 (CE 229); cf. Corbett, Roman Law, 210-217.

${ }^{143}$ Ovid Ars Amatoria 3-4; Plutarch Marius 16.7, in Lives.

${ }^{144}$ Juvenal Satires 3.45-46, 6.234-235; Balsdon, Roman Women, 275.

${ }^{145}$ Plutarch Aemilius Paullus 5.2-5, in Lives; and his Moralia 141A; Balsdon, Roman Women, 211 212. 
"Religion" seemed to have helped squelch some violent marital quarrels, offering hope for reconciliation. On the Palatine hill at Rome stood the temple of Juno Viriplaca, the "Juno, the appeaser of husbands." A husband and wife who had had a spat visited this sanctuary, and reportedly returned home happily reconciled. ${ }^{146}$

The histories of unhappily married couples (some who eventually divorced) are long and novelesque. Women appear to carry the day when it came to irritating their men (perhaps there were no irritating husbands). Quintus observed that "life offered no happiness greater than a single bed" with a wife who refused to give in to the most “simple" requests. "Day after day it is like this," Quintus told his brother Cicero. ${ }^{147}$

Juvenal describes a variety of intolerable wives: A wife who took to looking and talking like anything but a Roman woman; the wife who disliked and antagonized her husband's friends; the wife who was "corrupted" by her mother; the bickering and nagging wife; the gossiping women; women gross in their behavior; a woman who took on to wearing blue stockings; and so forth. ${ }^{148}$ Pliny the Elder notes several examples of Roman severity in the treatment of wives. Wine drinking was a cause for divorce and the loss of her dowry should the wife be caught, because wine-drinking was believed to

\footnotetext{
${ }^{146}$ See Maximus de Zamoras 2.1.6; Balsdon, Roman Women, 212.

${ }^{147}$ Cicero Letters to Atticus 5.1.3-4, 14.13.5. Also, see W. H. Johnson, "The Sister-in-law of Cicero," CJ (1913): 160-165.

${ }^{148}$ See Juvenal Satires $6.82-113$. Juvenal also writes about a senator's wife who ran away with a gladiator, 110-113; the domineering wife, 206-230; the athletic wife, 246-267; the unfaithful wife, 268-285; the musical wife, 379-397; the grossly masculine wife, 412-433; the wife with multiple lovers, 398-412.
} 
cause infertility in women. ${ }^{149}$ Cato muses that the reason women were kissed by their husbands was to discover the smell of drink. ${ }^{150}$

An intolerable frustration that developed between a husband and a wife was when a considerable time passed and the marriage produced no off-spring. Failure to have children was the ground for what Roman tradition believed to be the first divorce in a Roman marriage. ${ }^{151}$ A state of desperation took barren women to the streets of Rome on February 15 th, the day of the Lupercalia,${ }^{152}$ holding out their hands, so that half-naked priests might strike them with thongs of goat skin. This and other devices generally failed. ${ }^{153}$ It may not have been very common, but many a time a wife in this dilemma took the initiative, suggesting to her husband that he should divorce her and look for a wife who was likely to prove fertile. ${ }^{154}$

There were different standards for husbands and wives. "A perfect wife is as rare as a black swan," wrote Juvenal. And added, "What of the miser, the lecher to whom decent Roman women had the misfortune to find themselves married to?"155 Extant ancient sources of social criticism appear to be of the male preserve. Social critics took for granted and frankly admitted that there was one standard of moral behavior for wives and another for husbands. Cato the Elder smugly stated: "If you should take your wife in

\footnotetext{
${ }^{149}$ Pliny the Elder, Natural History 14.89-90; see also Plutarch Questions 6.

${ }^{150}$ Tacitus Annals 4.53.3; Balsdon, Roman Women, 213.

${ }^{151}$ Plutarch Questions 14; Gellius Attic Nights 4.3.2.

${ }^{152}$ A festival promoting fertility and the averting of evil forces; see $O L D$, s.v. "Lupercalia."

${ }^{153}$ Plutarch Romulus 21.7, in Lives; Ovid Caesar 61.3; Ovid Fasti 2:425-432.

${ }^{154}$ See Fowler, Social Life, 158-167.

${ }^{155}$ Juvenal Satires 6.165 .
} 
adultery, you may with impunity put her to death without trial. If you commit adultery or indecency yourself, she dare not lay a finger on you, and she has no legal right to do So." 156

Rare and few were the voices who rose against such abuses. Musonius Rufus (first century CE) is one of a few lonely voices who held the married state in high esteem, believing in the equality of the sexes. Musonius protested against the moral convention of his time which, while condemning the woman for infidelity with one of the house-slaves, considered her husband to be within the rights if he slept at will with any of the slavegirls. This same view had, in fact, a long tradition in Roman society. In Cato's Plautus, an old slave-woman exclaimed after detecting her master with a mistress: "Oh, I wish there was the same rule for the husband as for the wife ... the same way as wanton wives were divorced, I warrant there be more lonely men than there are now women."

Friedlander reports that Ovid and Pliny the Younger had three wives; Caesar and Anthony four; Sulla and Pompey five. Women remarried as often. Cicero's daughter, Tullia, remarried three times, and Nero was the third husband of Poppaea, and the fifth of Statilia Messalina. ${ }^{158}$

Long-term marriages appear to be a rarity. An inscription in a tomb dated between 18-2 BCE by Quintus Lucretius Vespillo (consul 19 BCE) to his wife Turia perhaps summarizes the divorce situation at Rome at such an early period in the Empire: "Uncommon are marriages which last so long, brought to an end by death, not broken

\footnotetext{
${ }^{156}$ Gellius Attic Nights 10.23.5.

${ }^{157}$ Rufus Musonius Rufus (trans. Jagu, 68); cf. Nixon Plautus 823-829.

${ }^{158}$ Ludwig Friedlander, Roman Life and Manners under the Early Empire (New York: E. P.
} 
apart by divorce; for it was our happy lot that it should be prolonged to the 41 st year without estrangement." ${ }^{\prime 59}$ But even in this marriage, after the death of her only daughter, Turia had proposed a divorce so that her husband might have children by a second, for childless men were under a disability in inheritance. She herself would seek him a new wife, and be a second mother to his children, and a sister or a mother-in-law to him, while their properties should remain undivided. ${ }^{160}$

\section{Summary and Conclusions}

Seneca, around the time Mark the evangelist was penning his version of Jesus' statement on "divorce," writes:

Is there any woman that blushes at divorce now that certain illustrious and noble ladies reckon their years, not by the number of consuls, but by the number of their husbands, and leave home in order to marry, and marry in order to be divorced? They shrank from this scandal as long as it was rare; now, since every gazette has a divorce case [literally, divorce certificate (divortio acta)], they have learned to do what they used to hear so much about. Is there any shame at all for adultery now that matters have come to such a pass that no woman has any use for a husband.... And the day is not long enough for them all, but she must be carried in her litter to the house of one and spend the night with another. She is simple and behind the times who is not aware that living with one paramour is called "marriage"! As the shame of these offences [sic] has disappeared now that their practice has spread more broadly ... ${ }^{161}$

Summarizing the duration of the marriage under Imperial Roman law, but not limited to it, are the following factors:

1. The introduction of the free marriage system

Hutton, 1908), 242-243.

${ }^{159}$ Erik Karl Hilding Wistrand, The So-called Laudatio Turiae: Introduction, Text, Translation, and Commentary, vol. 34, Studia Graeca et Latina Gothoburgensia (Göteborg: Acta Universitatis Gothoburgensis, 1976), 34:18.

\footnotetext{
${ }^{160}$ Wistrand, Laudatio Turiae, 19-21.

${ }^{161}$ Seneca “On Benefits” 3.16.2-4, in Seneca: Moral Essays (trans. Basore, LCL, 3:154-157).
} 
2. The young age at which marriage was contracted and consummated

3. The practice of fictitious marriages

4. Women's gain of independence

5. Immoral behavior

6. Unhappiness in marriage

7. A woman's infertility

8. The different standards under which husbands and wives were held in a marriage

9. The frivolity into which many entered the marriage state

10. The long periods of absence of the husband, most commonly due to military service

11. The captivity of soldiers or public servants who generally were turned into slaves

12. Criminality, true or fabricated, separated husbands permanently from their wives and annulled the marriage.

The easiness in which the Romans divorced and remarried in the Roman system should not surprise us as to the impact that Greco-Roman influences had on Palestinian society, especially among the affluent and powerful segments of the population who were not only exposed (and likely enjoyed imitating), but who also had the opportunity to travel to important cities of the empire, especially Rome. That the so-called "Roman influence" in Mark 10:12 may be found within northern Palestine had the famous case of Herodias divorcing her own husband, Philip the Tetrarch, to marry his brother Herod Antipas, is not surprising. 
This question of "divorce," whether through the legal dissolution of marriage or through desertion or expulsion, became a cause of concern for John the Baptist and Jesus as addressed by Mark concerning the Herodian house to his Gentile-Palestinian audience. This certainly appears to be the main question brought up to Jesus by the Pharisees as to whether he approved such practices under Jewish laws and customs. ${ }^{162}$ Jesus' counterquestion, "What did Moses command?" (Mark 10:3), clearly suggests that the Roman practice of simple expulsion from the house without the benefit of a "bill of divorcement" contradicted the Mosaic mandate. That Jesus was not "speaking up" as forcefully against the Antipas as John the Baptizer had, seems to be behind the Pharisaic question posed to Jesus, couched in their agenda to "entrap" him and thus carry out their sinister plan against him as the Herodians did against the Baptizer. With Roman divorce practices in the background, chapter 4 focuses on whether a contextual analysis supports this view.

\footnotetext{
${ }^{162}$ This is how Josephus reports it happened. See Antiquities 18.5.4.
} 


\section{CHAPTER 4}

\section{A TEXTUAL AND LEXICAL ANALYSIS OF MARK 10:1-12}

\section{Introduction}

Many OT and NT scholars have already noted the importance of the study of the divisions of the biblical texts and the need to study the interrelationships between sections (intertextuality). ${ }^{1}$ And because the Gospels have been fragmented into literary units purported to have come from the oral tradition and strung together by the evangelists, an approach widely accepted in Synoptic studies, ${ }^{2}$ the need to study individual units (pericopae) in their larger structures (a "redactional-theological approach" $)^{3}$ is validated. The purpose of this chapter is threefold:

${ }^{1}$ For a view on the theoretical aspects of pericope delimitations in the Gospels, see David L. Dungan, "Theory of Synopsis Construction," Biblica 61 (1980): 305-329. For a comprehensive overview on the praxis of delimitation of pericopae, though limited to the Gospel of Matthew, see Mark B. Regazzi, "The Delimitation of Pericopes: A Case Study in Matthew" (Ph.D. diss., Andrews University, 2000). For an OT approach, see David W. Baker, "Diversity and Unity in the Literary Structure of Genesis," in Essays on the Patriarchal Narratives, ed. Alan R. Millard and Donald J. Wiseman (Leicester, UK: InterVarsity, 1980), 189-205.

${ }^{2}$ It is beyond the scope of this dissertation to enter into the discussion of Form Criticism. It is worth noting that a number of NT scholars subscribe to the notion that the pericopae in the Synoptic Gospels are nothing more than "patch-work" accounts of isolated events. For a Historical-Critical approach, see Martin Dibelius, From Tradition to Gospel (New York: Scribner, 1965); cf. Rudolf Bultmann, History, 39-41; and Karl Ludwig Schmidt, Der rahmen der geschichte Jesu (Darmstadt: Wissenschaftliche, 1919). For an evangelical analysis, see Edgar V. McKnight, What Is Form Criticism? (Philadelphia: Fortress, 1969).

${ }^{3}$ In the 1950s, German NT scholar, Willi Marxsen, proposed, more forcefully than anyone before him, that the Gospel of Mark should be viewed as the work of a full-fledged author, rather than a document strung together by the Church. See Marxsen, Mark. Although I do not subscribe to all the premises of Redaction Criticism, that the Synoptic accounts are the redactional work of the evangelists themselves is the principium agendi of this study. For a mediating evangelical stance, see Stein, Gospels and Tradition. 
1. To establish the limits that encompass the Markan "divorce" pericope by analyzing the technical aspects as a literary unit (the macro structure), and the subdivisions (if present) of smaller sections (the micro structures from within the pericope). This exercise should identify the indicators of continuity and/or discontinuity which may confirm Mark's contextual understanding in which Jesus placed the teaching concerning "divorce" and the overall progression in his narrative. This will be done by analyzing syntax, words, and phrases as the possible "connectors" of the unit antecedent to the "divorce" pericope of Mark 10:1-12.

2. To investigate the preponderant word or words used for divorce in the Greekspeaking world. This study will be done through a structural and lexical analysis in which the different sentence connectors may aid in identifying the evangelist's intended message on "divorce.",

3. Observe the similarities and/or dissimilarities between the Markan and Matthean accounts as to the use of $\dot{\alpha} \pi 0 \lambda u^{\omega} \omega$ and derivatives.

\section{The Delimitation of the Pericope}

Within the body of any given biblical text, and especially in the Synoptic Gospels, there are indications of divisions, specifically in the higher discourse levels such in selfcontained stories and/or miracles, called pericopae. ${ }^{5}$ In many instances, Bible students

\footnotetext{
${ }^{4}$ Since $\dot{\alpha} \pi \circ \lambda \hat{v} \omega$ is the term most Bible versions translate "to divorce" in the Synoptic "divorce" passages, see the appendix for an investigation into the use of $\alpha$ mo $\lambda$ ú $\omega$ in the LXX, the NT, and in noncanonical works in the two centuries preceding and in the two centuries following the NT period.

${ }^{5}$ For a fuller definition, see Rolf O. Kroeger, "Pericope," The International Standard Bible Encyclopedia, ed. Geoffrey W. Bromiley (Grand Rapids, MI: Zondervan, 1991), 3:770; cf. Dictionnaire de la foi chrétienne, ed. Olivier de la Brosse, Antonin-Marie Henry, and Philippe Rouillard (Paris: de Cerf, 1968), s.v. "Péricope."
} 
find internal divisions within the pericopae themselves. As a necessary approach in the preliminary study of a text, it is important to identify the delimitations of a pericope from its larger context. Green points out that the lack of attention to the analysis of "patterns, clues, and contexts which affect the meaning," has given way to too many "dubious" interpretations, and that none more so than in the Markan Jesus on divorce. ${ }^{6}$

We find it imperative to analyze that which is objectively determinable (the technical aspects of the written text) before we can determine that which is subjectively proposed (the possible or probable interpretation/meaning of the text). The Markan pericope on "divorce" (10:1-12) can be viewed as a complete unit based on a number of indicators.

The first major indicator involves syntactical indicators of discontinuity in the areas of time, venue, and subject. These syntactical indicators clearly delimitate the Markan "divorce" pericope and are supported by the Matthean account (19:1-12), which also agrees with the general structure of the event:

1. Change in time: In both accounts (Markan and Matthean) there is a specific stated change in time: "then he arose from there and came" (Mark 10:1; Matt 19:1).

2. Change of venue: "then he left there [Galilee] and went to the region of Judea and beyond the Jordan" (Mark 10:1). "He went away from Galilee and entered the region of Judea" (Matt 19:1).

3. A change in subject matter: Although the Markan and Matthean "divorce" accounts do not contain similar endings, there is, however, a clear sign of discontinuity to

\footnotetext{
${ }^{6}$ See Barbara Green, “Jesus' Teaching on Divorce in the Gospel of Mark," Journal for the Study of the New Testament 38 (1990): 68.
} 
the pericopes in that when both accounts end, a new unit begins with a similar theme: the blessing of the children (Mark 10:13-17; Matt 19:13-15). In these three respects alone, Mark 10:1-12 (and Matt 19:1-12) can be considered a self-contained unit which deals only with the question of the Pharisees, a clear indication that the pericope belongs to a larger literary structure, rather than a statement collected in isolation.

The second major indicator deals with the structural function of the framework of the text which includes headings, superscripts, and summaries as well as repeated literary patterns or formulas, all of which are clearly identifiable. It is not very difficult to detect a distinct unit when seen in a formal literary structure (see the structural analysis below).

The third major indicator has to do with rhetorical devices which point to a selfcontained unit distinct from its general context. The unity can be discerned through questions and/or commands in which there are answers to the original question. In the case of Mark 10:1-12 one finds a consistent repetition of vocabulary or phraseology both at the beginning and at the end of the pericope, clearly setting the unit apart from its general context. The use of $\epsilon^{\prime} \pi \eta \rho \omega^{\prime} \tau \omega \nu$ by the Pharisees in 10:2 and by the disciples in the house in 10:10 is a feature which clearly betrays the editor's hand at work. ${ }^{7}$

A fourth indicator of unity has been pointed out by Neirynck, ${ }^{8}$ and elaborated by Collins $^{9}$ in which dualistic features identify Mark's personal style. Some of these are:

1. Repetition of cognate verbs ("he answered them," 10:2; "they said," 10:2; "he

${ }^{7}$ See p.27, n.96.

${ }^{8}$ Frans Neirynck, Duality in Mark: Contribution to the Study of the Markan Redaction, Bibliotheca ephemeridum theologicarum lovaniensum 31, rev. ed. (Leuven, Belgium: Leuven University Press, 1988), 14-17.

${ }^{9}$ R. F. Collins, Divorce, 74-77. 
said," 10:3,11; "they asked," 10:2; "they asked," 10:10)

2. His contrast of the negative and positive (10:8-9)

3. Repetition of antecedents (10:11)

4. The double local situation (10:1)

5. The repetition of the motif $(10: 2,8,10)$

6. A quotation with a comment (10:6-8a; $8 \mathrm{~b}-9)$

7. Correspondence in discourse $(10: 2,3,4,5$ and $2,11,12)$

Other important indicators of unity are discernible by the presence of verbal and nominal pronouns, some explicit, most of them implied, which tie the pericope together. ${ }^{10}$ Some of these implied personal pronouns point back to previously specified nouns, that is, "Moses allowed ..." (10:4); "but out of the hardness of your heart he wrote $\left(^{\prime} \epsilon \gamma \rho \alpha \psi \epsilon \nu\right.$, 10:5)." The implied personal pronoun "he," imbedded in " $\gamma \rho \alpha \psi \epsilon \nu$, is an obvious reference to Moses. A sequential use of such implied personal pronouns is clearly discernible throughout the pericope, which quite forcefully corroborate the unity and continuity of the Markan narrative from the previous chapter right into the "divorce" pericope.

Let us consider the first three verses of Mark (10:1-3), “And he left ( $\alpha \nu \alpha \sigma \tau \grave{\alpha} \varsigma)$ there and [he] went ( $\left.{ }^{\prime} \rho \chi \in \tau \alpha \iota\right)$ to the region of Judea and beyond the Jordan. And crowds again gathered to him ( $\sigma \cup \mu \pi 0 \rho \in \cup \dot{0} \nu \tau \alpha \iota)$; and again, as his custom was $\left(\epsilon i \omega^{\prime} \theta \in \iota\right)$, [he] taught

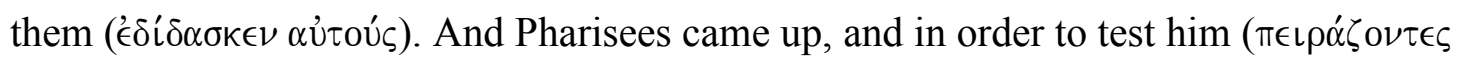

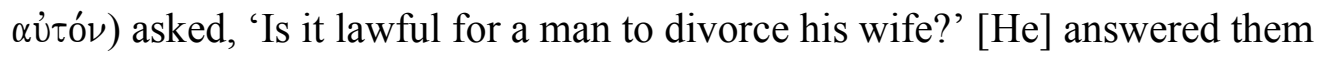

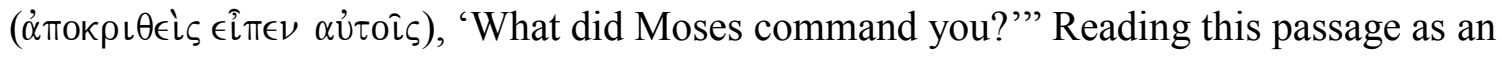

\footnotetext{
${ }^{10}$ Unless used for emphasis, biblical Greek does not generally use the personal pronoun. Personal pronouns in the Greek are identified by the ending of the verbal forms.
} 
independent unit one would need to be familiar with Jesus' activities in order to be able to supply the proper noun attached to this series of implied personal pronouns. To confirm who this "he" or "him" is, the reader would need to retrace his/her steps twelve verses from Mark 10:1 all the way to 9:39 to know that the proper noun belongs to Jesus.

The non-use of the proper noun "Jesus" in the transition from the previous pericope to the next is a clear indicator of the continuity of the narrative. Yet not only do the anaphoric uses of these pronouns show unity by tying a clause to a previously explicit designation, but also the verb is explicitly given at the introduction of the subject and used again at the end of the narrative. The redactional intention of the author can be gleaned within the same framework in the structural analysis below in figure 1.

\section{A Structural Analysis}

The following analysis attempts to ascertain the unity, continuity, and cohesiveness of the Markan "divorce" pericope. This pericope, which is part of a larger context (as shown above), is analyzed with the intention to show that the whole pericope (Mark 10:1-12) belongs within the same framework in which the evangelist attempts to interpret Jesus' teaching on the question of "divorce" to his Gentile audience in a Palestinian milieu. This process involves the delineation of key structural patterns based on lexical/grammatical, textual-syntactical analysis of key Greek words and phrases, and their grammatical-syntactical interconnectedness. 


\section{Figure 1. A Structural Analysis.}

\section{Mark 10:2}

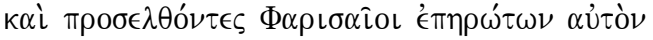

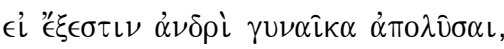

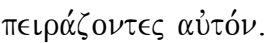

\section{$\mathbf{A}^{2} \mathbf{a}$}

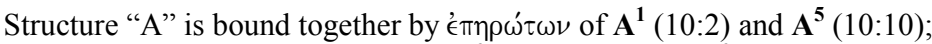

and by the derivatives of $\dot{\alpha} \pi 0 \lambda \dot{v} \omega$ in $\mathbf{A}^{\mathbf{2}} \mathbf{a}$ (10:2) through $\mathbf{A}^{\mathbf{2}} \mathbf{d}$ (10:12).

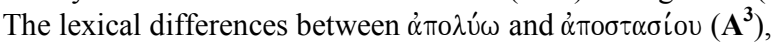

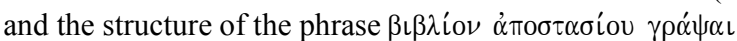

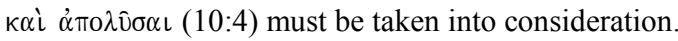

\section{Mark 10:3}

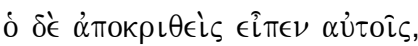

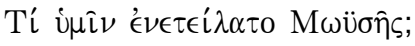

\section{Mark 10:4}

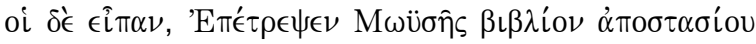

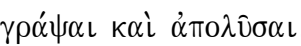

\section{$\mathbf{A}^{3}$}

\section{$\mathbf{A}^{2} \mathbf{b}$}

In parallel (contextual) word studies a given word and derivatives must mean the same thing, or be closely related, but cannot have different meanings. Most translations render the derivatives of $\dot{\alpha} \pi \mathrm{T} \lambda \mathrm{u} \omega$ " to divorce," but not in $\mathbf{A}^{\mathbf{2}} \mathbf{b}$ where most versions translate "to dismiss" (see Tables 1-4)

\section{Mark 10:5}

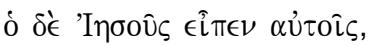

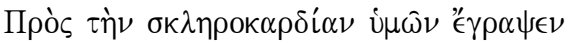

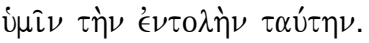

Mark 10:6 In $\mathbf{B}^{1}$ "Male and female-one flesh" stands in contrast to the "arteriosclerosis" of patriarchal male-dominated practices.

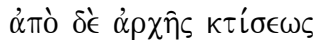

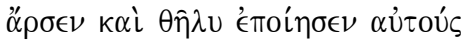

Mark 10:7

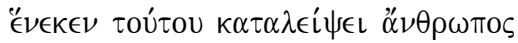

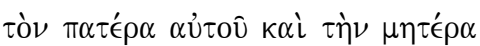

$\epsilon i \varsigma \sigma \alpha \dot{\rho} \kappa \alpha \mu \dot{i} \alpha \nu$

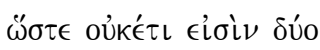

$\dot{\alpha} \lambda \lambda \dot{\alpha} \mu \dot{\alpha} \alpha \sigma \alpha \dot{\rho} \xi$.

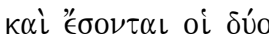

$B^{4}$

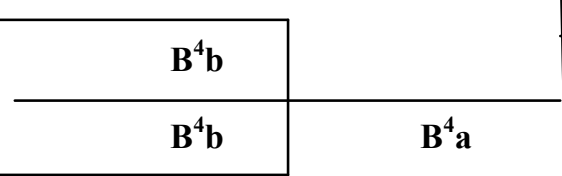


Figure 1-Continued.

Mark 10:9

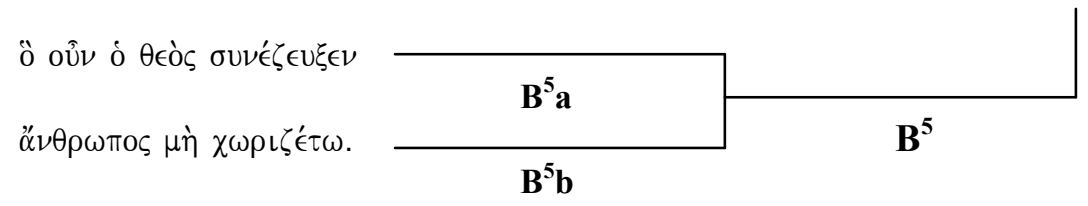

$\mathrm{X} \omega \rho \iota \zeta^{\prime} \epsilon \omega$ of $\mathbf{B}^{5} \mathbf{b}$, not only a legal term used for divorce (see 1 Cor 7:11,15), but it is also the modern Greek term.

Here in Mark 10:9 it is a direct reference to the "one flesh" concept of 10:8; and an apparent indication against divorce, which none of the modern versions translate as such.

\section{Mark 10:10}

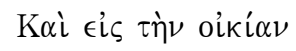

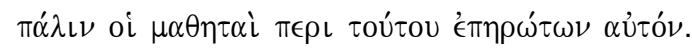

$\mathbf{A}^{5}$

\section{Mark 10:11}

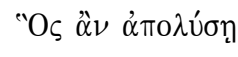

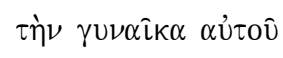

$\mathbf{A}^{2} \mathbf{c}$

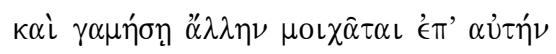

\section{Mark 10:12}

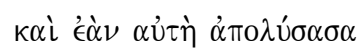

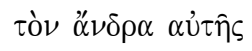

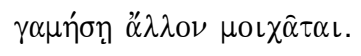

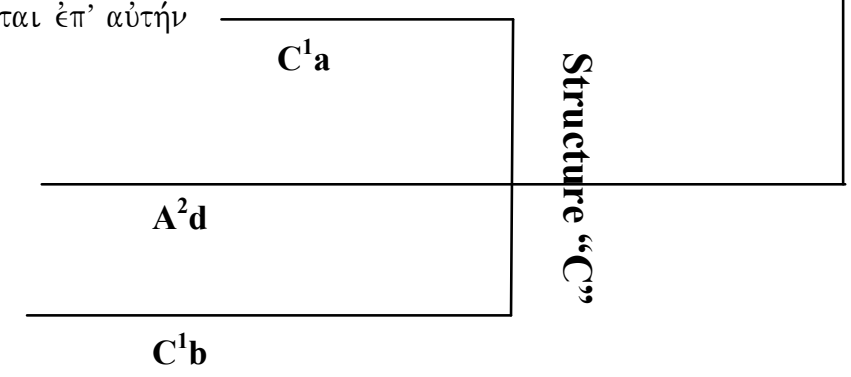

\section{A Lexical and Syntactical Analysis of Mark 10:2-12}

The following analysis will attempt to look into some of the lexical and syntactical nuances of specific words that may affect the understanding of the Markan "divorce" teaching. The accompanying "loose" translation is being done with the purpose of elucidating possible meanings gleaned from the various translations: 


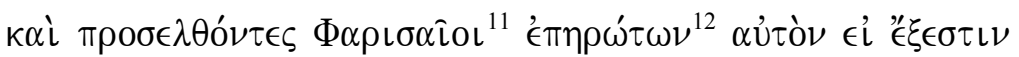

And having come [some] Pharisees continued to ask him if [it is] proper

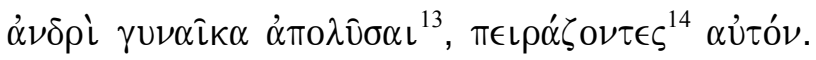

[a] man [his] wife/woman to dismiss/send away/expel, testing/tempting him.

$10: 3$

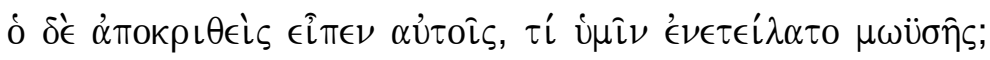

And answering he said to them, "what did Moses command you?"

$10: 4$

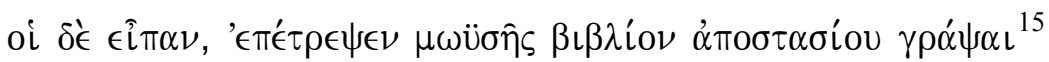

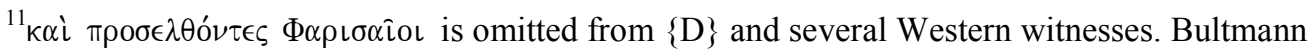
considers that this omission should not appear in modern translations. Rudolf Bultmann, History, 52. If "Pharisees" is a late assimilation, then ' $\epsilon \eta \rho \omega^{\prime} \tau \omega \nu$ is an impersonal plural and Mark would be indicating that some people questioned Jesus. Metzger believes that the external evidence for including "Pharisees" is an "excellent intrinsic probability," without excluding the possibility that it could have been originally omitted. Bruce M. Metzger, A Textual Commentary on the Greek New Testament (New York: United Bible Societies, 1971), 103-104.

${ }^{12} € \pi \eta \rho \omega^{\prime} \tau \omega \nu$ is the imperfect, third person, plural of the verb ' $₫ \eta \rho \omega \tau \alpha^{\prime} \omega$. An iterative imperfect defines a state of existence or an action in progress in past time. The "continued" or "repeated" action of "tempting" or "testing" Jesus does not culminates in this verse. The Markan thrust is evident throughout the whole Gospel which points to some Pharisees, at times in conjunction with the Herodians, progressively attempting to trap Jesus (See Mark 2:6, 16, 18, 23; 3:1, 22; 8:11, 15; 10:2; 12:13).

${ }^{13}$ The anarthrous infinitive in this case expresses purpose: "Is it right for a male to 'purposely' or 'intentionally' expel/send away/dismiss his wife [from his house]?" "To divorce" does not appear to be the intended meaning of $\alpha \pi 0 \lambda \hat{\sigma} \sigma \alpha \iota$ in 10:2 given the answer in 10:4 to Jesus' question in 10:3, "What did Moses

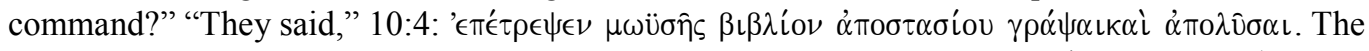

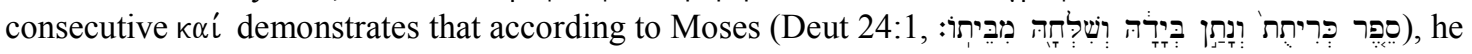

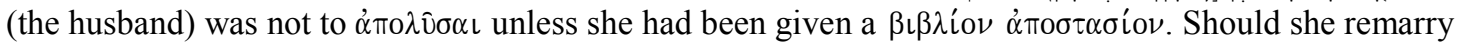

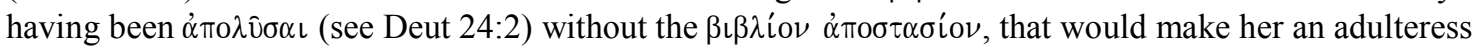
(see 10:11 where having been sent out, apparently without the letter of divorce, causes her to commit

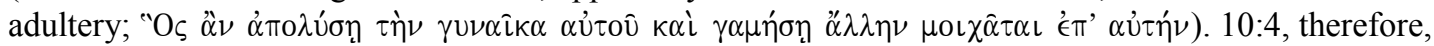
sheds light on the intended "entrapment" $(\pi \in \iota \rho \alpha \zeta \zeta \omega)$ of the Pharisaic question of 10:2.

${ }^{14}$ The present, active participle is gnomic expressing a continued or repeated action which can be translated "made a practice at tempting/testing him," supported by Mark. 
And they said, "Moses allowed to write a letter of divorce

$\kappa \alpha \grave{\alpha} \pi 0 \lambda \hat{\sigma} \sigma \alpha \iota$.

and to dismiss [her]/send [her] away/expel [her]."

$10: 5$

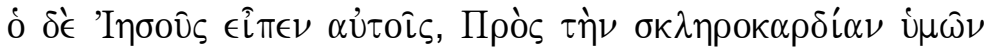

And Jesus said to them, "for the hardness of your heart

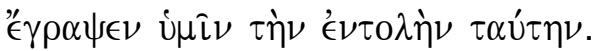

he [Moses] wrote to you this commandment;

$10: 6$

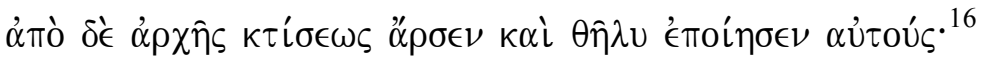

but from [the] beginning of creation male and female he made them.

$10: 7$

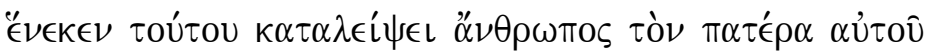

On account of this [a] man will leave his father

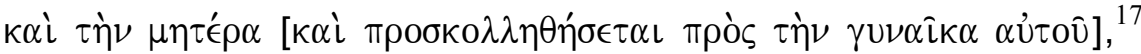

and mother [and attaches to his wife]

${ }^{15}$ The letter of divorce, according to Deut $24: 1$, was written so that the woman ejected ( $\kappa \alpha \iota$, followed by $\alpha \operatorname{\pi } \alpha \hat{v} \sigma \alpha \iota$, elucidates the "intentionality" of the anarthrous infinitive.

${ }^{16} \mathrm{~A}$ large number of Minuscules, as well as two major Uncials, "A" (Alexandrinus) and " $\Theta$ " (Koridethi), contain ó $\theta \epsilon o ́ \varsigma$ at the end of v. 6. The addition, however, does not alter the meaning of the text; rather, it enhances it.

${ }^{17}$ This bracketed statement is found in $\mathrm{D}, \mathrm{K}, \mathrm{W}, \Theta, \Pi, \mathrm{f}^{13}$, and other Minuscules. This variant, considered "weak" \{D $\}$ by UBS editors, is based on Gen 2:24. Other important MSS that contain it have

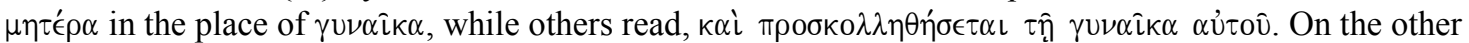
hand, MSS such as a, B, $\Psi$, Greek lectionary 148, syr ${ }^{\mathrm{s}}$ (Sinaitic Syriac), omit the addition, considering it "improbable" (et improbitas mulieren it). 
$10: 8$

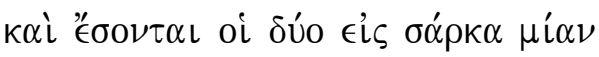

and the two shall be one flesh.

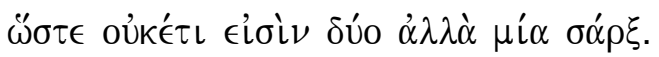

Thus they are no longer two but one flesh.

$10: 9$

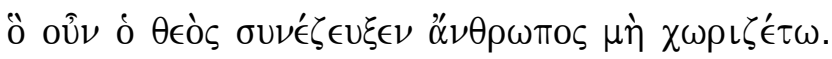

Therefore what God joined together let not man separate."

10:10

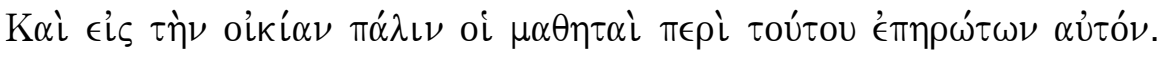

And in the house again the disciples questioned him regarding this [matter].

$10: 11$

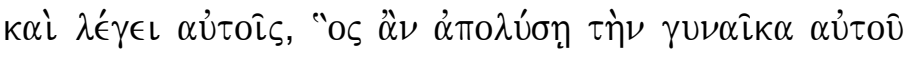

And he says to them, "whoever dismisses/divorces/sends away his wife

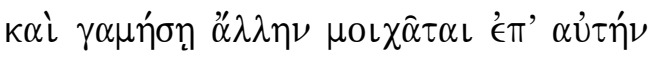

and marries another [woman] commits adultery against her.

$10: 12$

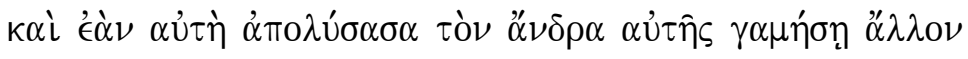

And if she dismisses/puts away/divorces her husband and marries another [man], $\mu o \iota \chi \hat{\alpha} \tau \alpha \iota$.

[she] commits adultery.

\section{'A}

At the crux of the above analysis lie derivatives of the Greek word $\alpha$ mo $\lambda \dot{u} \omega$,

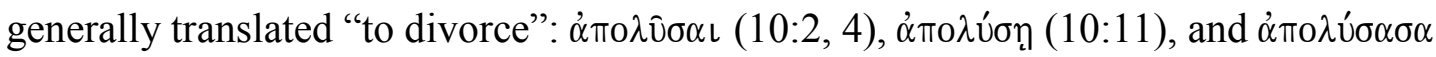


$(10: 12)$. The meaning of this word and its proper derivatives in their contextual and intertextual setting may determine the correct translation and the author's original intention. The lexical entries for the derivatives of $\dot{\alpha} \pi 0 \lambda \hat{\omega} \omega$ render it: "to repudiate," "to put away," "to send away," "to dismiss," "to set free," "to release," "to leave," "to

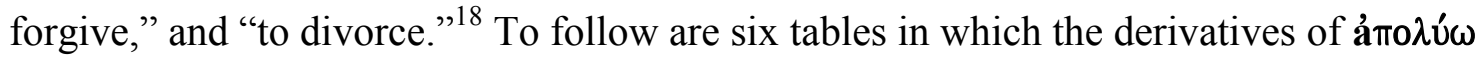
are translated in various Bible versions and/or languages. The purpose is to attempt to highlight the disagreement among different English and Spanish versions and a few nonEnglish translations in an attempt o elucidate whether divorce is at the crux of the Pharisaic question of Mark 10:2. The text reads: "Some Pharisees came and tested him by asking: 'Is it lawful for a man to $\alpha \pi 0 \lambda \hat{\sigma} \sigma \alpha \iota$ his wife?'”

\footnotetext{
${ }^{18}$ Grammatical and syntactical nuances of Greek terms used throughout this study are based on BDAG; Daniel B. Wallace, Greek Grammar Beyond the Basics: An Exegetical Syntax of the New Testament (Grand Rapids, MI: Zondervan, 1996); James A. Brooks and Carlton L. Winbery, Syntax of New Testament Greek (Lanham, MD: University Press of America, 1979); C. F. D. Moule, An Idiom Book of New Testament Greek, 2nd ed. (Cambridge: Cambridge University Press, 1959); and Hermeneutika BibleWorks 8.0 (Big Fork, MT, 2007).

${ }^{19}$ The Matthean account $(19: 3,7)$, apart from a few variations, contains the same Markan $(10: 2,4)$ Greek words. Since every new edition of the cited Bible versions maintains the same translation to the derivatives of $\dot{\alpha} \pi 0 \lambda \cup ́ \omega$, bibliographic information will be supplied only for those Bible versions published only once.
} 
Table 2. Comparison of translations for $\alpha$ đо $\lambda \hat{\sigma} \sigma \iota \iota$ in English Bibles on Mark 10:2, 10:4, and Matthew 19:3.

\begin{tabular}{|c|c|c|c|}
\hline Version & Mark 10:2 & Mark 10:4 & Matt 19:3 \\
\hline CEB & Divorce & Divorce & Divorce \\
\hline CJB & Divorce & Divorce & Divorce \\
\hline $\mathrm{CSB}$ & Divorce & Send Away & Divorce \\
\hline DRA & Put Away & Put Away & Put Away \\
\hline ESV & Divorce & Send Away & Divorce \\
\hline KJV & Put Away & Put Away & Put Away \\
\hline NKJ & Divorce & Dismiss & Divorce \\
\hline NAB & Divorce & Dismiss & Divorce \\
\hline NAU (NAS) & Divorce & Send Away & Divorce \\
\hline NET & Divorce & Divorce & Divorce \\
\hline NIRV & Divorce & Send Away & Divorce \\
\hline NIV & Divorce & Send Away & Divorce \\
\hline NJB & Divorce & Divorce & Divorce \\
\hline NLT & Divorce & Send Away & Divorce \\
\hline NRS & Divorce & Divorce & Divorce \\
\hline RSV & Divorce & Put Away & Divorce \\
\hline
\end{tabular}


Table 3. A comparison of translations for $\alpha$ đo $\lambda \hat{\sigma} \sigma \alpha \iota$ in Spanish Bibles on Matthew 19:3, Mark 10:2, and 10:4

\begin{tabular}{|c|c|c|c|c|}
\hline Bible & $\mathrm{C}$ or $\mathrm{P}$ & Matt 19:3 & Mark 10:2 & Mark 10:4 \\
\hline BNP - La Biblia de Nuestro Pueblo & $\mathrm{C}$ & Separarse & Separarse & Separarse (vs 3) \\
\hline CAB - La Biblia & $\mathrm{P}$ & Despedir & Despedir & Despedirla \\
\hline LBA - La Biblia de Las Americas & $\mathrm{P}$ & Divorciarse & Divorciarse & Repudiar \\
\hline NBH - Nueva Biblia de Los Hispanos & $\mathrm{P}$ & Divorciarse & Divorciarse & Repudiar \\
\hline NVI - Spanish, NIV & $\mathrm{P}$ & Divorcio & Divorcio & Despedirla \\
\hline PER - La Biblia del Peregrino & $\mathrm{C}$ & Repudiar & Repudiar & Repudiar \\
\hline R-60 - Spanish Reina Valera Revised [cf. RSV] & $\mathrm{P}$ & Repudiar & Repudiar & Repudiar \\
\hline R-95 - Spanish Reina Valera Revised & $\mathrm{P}$ & Repudiar & Repudiar & Repudiar \\
\hline RVG - Reina Valera Gomez & $\mathrm{P}$ & Repudiar & Divorciarse & Despedirla \\
\hline SRV - Reina-Valera Bible 1909 [TR base] & $\mathrm{P}$ & Repudiar & Repudiar & Repudiar \\
\hline RVA - Reina-Valera Actualizada & $\mathrm{P}$ & Repudiar & Repudiar & Despedirla \\
\hline
\end{tabular}




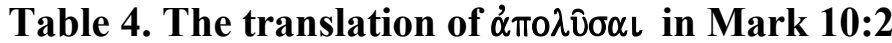

\begin{tabular}{|c|c|c|c|}
\hline To Divorce & To Repudiate & To Put Away & To Leave \\
\hline $\begin{array}{l}\text { LBA - La Biblia de Las } \\
\text { Americas }^{\mathrm{a}}\end{array}$ & PER - La Biblia del Peregrino & $\begin{array}{l}\text { BNP - La Biblia de Nuestro } \\
\text { Pueblo }^{b}\end{array}$ & CAB - La Biblia \\
\hline $\begin{array}{l}\text { NBH - Nueva Biblia de } \\
\text { Los Hispanos }\end{array}$ & $\begin{array}{l}\text { R-60 - Spanish Reina Valera } \\
\text { Revised [cf. RSV] }\end{array}$ & & \\
\hline NVI - Spanish NIV & $\begin{array}{l}\text { R-95 - Spanish Reina Valera } \\
\text { Revised }\end{array}$ & & \\
\hline $\begin{array}{l}\text { RVG - Reina Valera } \\
\text { Gómez }\end{array}$ & $\begin{array}{l}\text { RVA-Reina Valera } \\
\text { Actualizada }\end{array}$ & & \\
\hline CEB & $\begin{array}{l}\text { SRV - Reina Valera Bible } \\
1909\end{array}$ & & $\begin{array}{l}\text { Holy Bible from Ancient } \\
\text { Eastern MSS (Syriac tr.) }\end{array}$ \\
\hline CJB & Torres-Amat & & \\
\hline $\mathrm{CSB}$ & Versión Moderna & & \\
\hline ESV & Ferreira de Almeida & & \\
\hline$N A B$ & French versions & & \\
\hline \multicolumn{4}{|l|}{$N A S$} \\
\hline \multicolumn{4}{|l|}{$N E B$} \\
\hline NET & & ASV & \\
\hline NIRV & & DRA & \\
\hline NIV & & KJV & \\
\hline NKJ & & Companion Bible & \\
\hline NLT & & Douay $^{d}$ & \\
\hline NRS & & Geneva $^{e}$ & \\
\hline RSV & & Moulton ${ }^{f}$ & \\
\hline$B e c k^{g}$ & & Newberry ${ }^{h}$ & \\
\hline Berkeley $^{i}$ & & Scofield & \\
\hline Goodspeed & & Thompson & \\
\hline New Jerusalem & & Tyndale & \\
\hline New World Tr. & & Young $^{j}$ & \\
\hline \multicolumn{4}{|l|}{ Phillips $^{k}$} \\
\hline Williams $^{l}$ & & & \\
\hline
\end{tabular}

${ }^{a}$ La Biblia de las Américas (La Habra, CA: Editorial Fundación, 1986).

${ }^{\mathrm{b}}$ This version does not read a question in Mark 10:3 as all other versions, English and Spanish versions do, but makes verse 3 a straight indicative: "Respondieron: 'Moisés permitió escribir carta de divorcio y separarse"” ("He answered, 'Moses allowed to write a letter of divorce and to separate'.")

${ }^{\mathrm{c}}$ The Holy Bible from Ancient Eastern Manuscripts Containing the Old and New Testaments, trans. George M. Lamsa (Philadelphia: A. J. Holman, 1967).

${ }^{\mathrm{d}}$ The Duoay-Rheims American Edition (1899) in Hermeneutika 7.0.

${ }^{\mathrm{e}}$ The Geneva Bible: The Annotated New Testament, ed. Gerald T. Sheppard (1602; repr., New York: Pilgrim, 1989).

${ }^{\mathrm{f}}$ The Modern Reader's Bible: The Books of the Bible with Three Books of the Apocrypha Presented in Modern Literary Form, ed. Richard G. Moulton (New York: Macmillan, 1940).

${ }^{\mathrm{g}}$ The New Testament in the Language of Today, trans. William F. Beck (St. Louis: Concordia, 1963).

${ }^{h}$ The Newberry Bible (London: Hodder \& Stoughton, 1890).

${ }^{\mathrm{i}}$ New Berkeley Version in Modern English, ed. Gerrit Verkuyl (Grand Rapids, MI: Zondervan, 1969).

${ }^{\mathrm{j}}$ The Young's Literal Translation of the Holy Scripture, trans. Robert Young (Grand Rapids, MI: Baker, 1953).

${ }^{\mathrm{k}}$ The New Testament in Modern English, trans. J. B. Phillips (New York: Macmillan, 1972).

${ }^{1}$ The New Testament: A New Translation in Plain English, trans. Charles Kingsley Williams (London: SPCK, 1952). 
Tables 2 and 3 show that most Spanish Catholic versions predominantly translate $\dot{\alpha} \pi \circ \lambda \hat{\sigma} \sigma \alpha$ in Mark 10:2 "divorciar" ("to divorce"); while table 4 below shows how most Spanish, Portuguese, Italian, and French Protestant versions predominantly translate in the English equivalent "to repudiate" (Spanish and Portuguese "repudiar," Italian "repudiare," French "répudier," while the German contains "scheiden lassen," literally "to divorce"). Although this term has a wide range of meanings, including to divorce, in the romance languages, the English equivalent "to repudiate" is more closely related to the concept of ejection, expulsion from one's home or abandonment (which in many instances may eventually lead to a divorce, but not necessarily). ${ }^{20}$ As noted in table 3, most Protestant versions translate $\dot{\alpha} \pi 0 \lambda \hat{v} \sigma \alpha$, , "to put away," as a possible inference to an expulsion, rather than divorce, whereas the Lamsa's Syriac translation contains the equivalency "to leave."

In the next statement, the Pharisees respond: "They said, 'Moses permitted a man to write a certificate of divorce and to $\dot{\alpha} \pi 0 \lambda \hat{v} \sigma \alpha \iota "(10: 4)$. Those Bible versions that translate $\dot{\alpha} \pi \mathbf{\lambda} \lambda \hat{v} \sigma \alpha \iota$ "to divorce" (see table 3) have had to do some syntactical "juggling" in which they are forced to translate "Moses permitted a man to write a $\beta \iota \beta \lambda$ iov

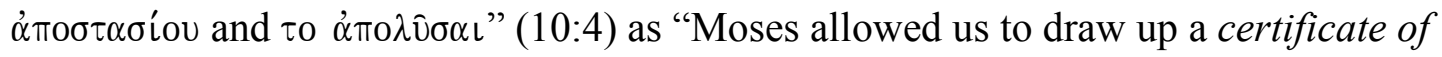

\footnotetext{
${ }^{20}$ The Spanish expression "el hombre repudió a su mujer" does not generally refer to a formal divorce, but rather a state of separation when a woman is ejected and told to leave her husband's household or where he packs his things and leaves. Women such as these may remain in legal limbo at the whim of their husbands. The Latin repudium is defined as "the unilateral repudiation of a betrothal or marriage in archaic Roman law where the betrothed/wife was suspected of adultery or other serious misconduct whose husband speedily ended the relationship without any legal recourse." See Adolf Berger, Encyclopedic Dictionary of Roman Law (Union, NJ: Lawbook Exchange, 2002), 435. See Marriage and Divorce under the Romans: I BCE to I CE in chapter 3 above.
} 
dismissal in cases of divorce" (emphasis supplied) or the cacophonic, "Moses permitted a man to write a certificate of divorce and to divorce."

Table 5. The translation of $\dot{\alpha} \pi 0 \lambda \hat{\sigma \alpha \alpha \iota}$ in Mark 10:4

\begin{tabular}{|c|c|c|c|c|c|}
\hline To Divorce $^{21}$ & To Repudiate & To Put Away & To Send Away & To Dismiss & To Let Go \\
\hline CEB & $\begin{array}{l}\text { Ferreira de } \\
\text { Almeida }\end{array}$ & ASV & $\begin{array}{l}\text { BNP-La Biblia de } \\
\text { Nuestro Pueblo }\end{array}$ & CAB - La Biblia & \\
\hline CJB & $\begin{array}{l}\text { LBA - Biblia de las } \\
\text { Américas }\end{array}$ & DRA & & NVI - Spanish NIV & \\
\hline NET & $\begin{array}{l}\text { NBH-Nueva } \\
\text { Biblia de Los } \\
\text { Hispanos }\end{array}$ & KJV & CSB & $\begin{array}{l}\text { RVA - Reina } \\
\text { Valera Actualizada }\end{array}$ & \\
\hline NJB & $\begin{array}{l}\text { PER - La Biblia } \\
\text { del Peregrino }\end{array}$ & RSV & ESV & $\begin{array}{l}\text { RVG-Reina } \\
\text { Valera Gomez }\end{array}$ & \\
\hline NRS & $\begin{array}{l}\text { R- } 60 \text { - Spanish } \\
\text { Reina Valera } \\
\text { Revised [cf. RSV] }\end{array}$ & & NAS & & \\
\hline Beck & $\begin{array}{l}\text { R-95-Spanish } \\
\text { Reina Valera } \\
\text { Revised }\end{array}$ & Douay & NIRV & & Berkeley \\
\hline Goodspeed & $\begin{array}{l}\text { SRV - Reina } \\
\text { Valera Bible } 1909\end{array}$ & Geneva & NIV & $N A B$ & \\
\hline $\begin{array}{l}\text { H. B. Ancient } \\
\text { Eastern MSS }\end{array}$ & Torres-Amat & Moulton & NLT & NKJ & \\
\hline Moffatt & Versión Moderna & Scofield & & Phillips & \\
\hline New Jerusalem & French versions & Thompson & & & \\
\hline New World & & Tyndale & & & \\
\hline $20^{\text {th }}$ Century & & Young & & & \\
\hline
\end{tabular}

That $\dot{\alpha} \pi 0 \lambda \hat{v} \sigma \alpha \iota$ should be simply translated "to dismiss," Boring explains, is because "the traditional translation 'divorce,' retained here for convenience [by most Bible translations], is actually too modern, and too moderate, a translation for the verb

${ }^{21}$ With those versions that translate $\dot{\alpha} \pi 0 \lambda \hat{v} \sigma \alpha \iota$ "to divorce" in Mark 10:2 and again in 10:4, the concept of a "dismissal" still needs to be included. Most translators changed the grammatical structure of Deut 24:1, "he writes her a certificate of divorce, puts it in her hand, and sends her out of his house" to "Moses allowed a man to write a certificate of dismissal and to divorce her" in Mark 10:4. Even though the Greek of Deut 24 does not contain the root for $\dot{\alpha} \pi 0 \lambda \hat{v} \omega$, the infinitive $\dot{\alpha} \pi \circ \lambda \hat{v} \sigma \alpha \iota$ in Mark 10:4 definitely contains the concept of "sending away," not divorcing. Translators did not convey the same idea for the same infinitve in Mark 10:2 or in Matt 19:3. 
$\dot{\alpha} \pi \mathrm{o} \lambda \dot{v} \omega$ and its cognate noun $\dot{\alpha} \pi \mathrm{o} \lambda \dot{v} \sigma \mathrm{s} \varsigma$. Since in the Old Testament and ancient Judaism it was the husband's prerogative, requiring no judicial decision, 'dismissal' is more accurate. ${ }^{22}$

The following statement is unique to Mark: “Anyone who $\dot{\alpha} \pi 0 \lambda$ v́øฺ̣ his wife and marries another woman commits adultery against her" (10:11). Table 4 shows how these versions translate $\dot{\alpha} \pi 0 \lambda$ v́oṇ.

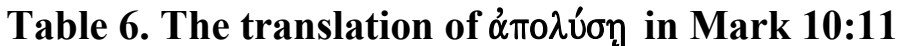

\begin{tabular}{lll}
\hline To Divorce & To Repudiate & To Put Away \\
\hline NAB & Biblia de las Américas & ASV \\
NAS & Ferreira de Almeida & KJV \\
$N E B$ & Reina-Valera & Companion Bible \\
NIV & Versión Moderna & Douay \\
NKJ & French Versions & Geneva \\
NRS & Spanish Catholic Versions & Moulton \\
REB & & Newberry \\
Berkeley & & Scofield \\
Goodspeed & & Tyndale \\
Moffatt & & Young \\
New Jerusalem & & \\
\hline
\end{tabular}

If the meaning of $\dot{\alpha} \pi 0 \lambda \dot{\sigma} \sigma \eta$, as rendered by most Protestant versions, is "to divorce," then the "fuzzy" translation "commits adultery against her" makes absolutely no sense. The only way in which a man could "causes her [his wife] to commit adultery" would be in a case where she would remarry after having been "sent away," "expelled"

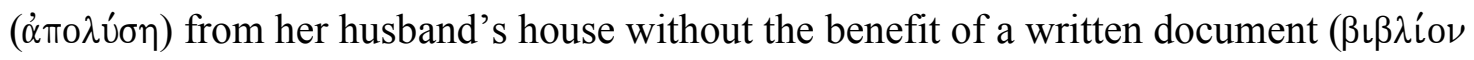

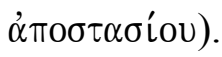

\footnotetext{
${ }^{22}$ Boring, Mark, 286.
} 
Mark 10:12 reads: "And if she $\alpha \dot{\pi} 0 \lambda \cup ́ \sigma \alpha \sigma \alpha$ her husband, marries another man, she commits adultery." Table 5 further refines the descriptions of the term.

Table 7. The translation of $\alpha \dot{\alpha} \pi \mathrm{\nu} \cup \dot{\sigma \alpha \sigma \alpha}$ in Mark 10:12

\begin{tabular}{lllll}
\hline To Divorce & To Repudiate & To Put Away & To Leave & To Forsake \\
\hline NAB & Biblia de las Américas & & Ferreira de Almeida & Tyndale \\
NAS & Reina-Valera & ASB & & \\
NEB & Versión Moderna & KJV & & \\
NKJ & French Versions & Douay & & \\
NRS & Spanish Catholic Versions & Newberry & & \\
NIV & & Young & & \\
REB & & & & \\
Berkeley & & & & \\
Goodspeed & & & & \\
Moffatt & & & \\
New Jerusalem & & & \\
\hline
\end{tabular}

If the Markan statement is reflective of a Roman practice, then it was perfectly normal for a plebeian woman to divorce her husband by simply deserting him (see chapter 3). In Jewish eyes, however, divorce was a male domain; should a woman

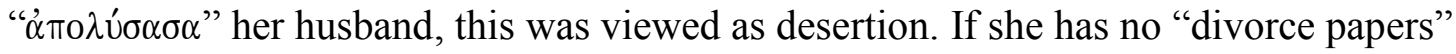
and marries another man, she then commits adultery. ${ }^{23}$

Against those who have posited that Mark 10:11-12 was a later addition by the Church, ${ }^{24}$ Meier has rightly noted that the whole pericope belongs to Mark in that he ties

\footnotetext{
${ }^{23}$ This does not mean that women could not initiate and secure a divorce in Judaism. Although not exactly known when these provisions existed, the rabbis stipulated different ways in which this could be done: (1) She could buy her own divorce by forgoing her ketubah (b. Git. 35a; b. Bava Metzi'a 65a). (2) She could write out her own divorce deed and it would be valid should she get him to sign it (b. Git. 22b). (3) Some ketubot might give her the right to divorce herself (j. Ket. 60b; j. Baba Batra 16c). (4) She could refuse sexual intimacy thus forcing him to divorce her ( $b$. Ned. 90b). For a detailed account of these and other methods, see J. Duncan M. Derrett, Law in the New Testament (London: Darton, Longman \& Todd, 1970), 386-388.

${ }^{24}$ See p. 28, n. 96 .
} 
together 10:2 with 10:11-12 by a consistent vocabulary. He notes that in the question, "Is

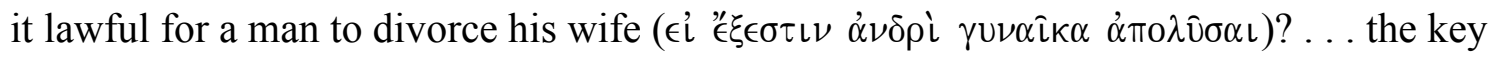
verb 'to divorce' ( $\dot{\alpha} \pi 0 \lambda \dot{U} \omega)$ disappears from the rest of the dispute with the Pharisees." Meier notes that it is only "when Jesus retires to the house ... that he takes up the language of the Pharisees' question." 25 This bodes well with the structural connectors

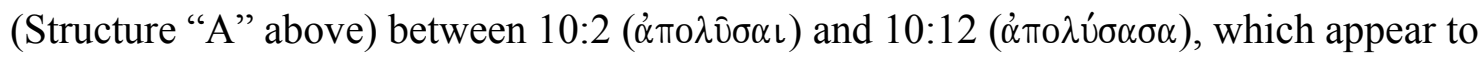
point out that the Pharisees' question was dealing with something other than divorce. That Jesus does not address the question (with the Pharisees using their choice of word $\dot{\alpha} \pi 0 \lambda \dot{U} \omega)$ indicates that the Markan allusion to this term is not connected with divorce.

This means that the only possible translations of the derivatives of $\dot{\alpha} \pi 0 \lambda \dot{u} \omega$ must mean "to dismiss," "to leave," "to forsake," "to put away," or even "to repudiate" in the Greek-Roman sense. Now, unless "to repudiate," "to put away," "to forsake," "to leave," "to send away," "to dismiss," "to let go," are all synonymous or interchangeable terms for "to divorce," one can see how the translation of $\alpha \pi 0 \lambda \dot{u} \omega$ and its derivatives in any of the most accessible languages in which the Bible is read can create insurmountable problems for the unaware Bible reader. Fee rightly points out that "whenever translations have truly significant differences between/among them, this is a sure indication that some exegetical difficulty lies behind the differences.",26

Though hardly the exception, we notice, for example, the inconsistency of a wellknown and widely used translation: the NIV. It reads: "Some Pharisees came and tested

\footnotetext{
${ }^{25}$ Meier, Law and Love, 4:199-120.

${ }^{26}$ Fee, New Testament Exegesis, 12.
} 


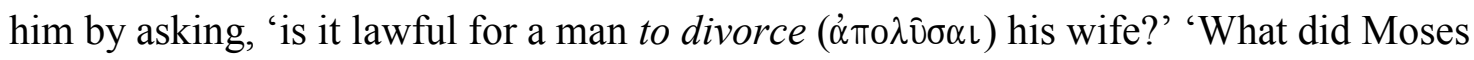
command you,' he replied. They said, 'Moses permitted a man to write a certificate of

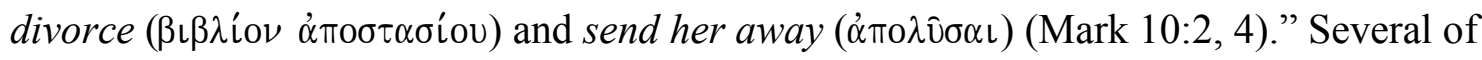
the above versions translate $\dot{\alpha} \pi 0 \lambda \hat{v} \sigma \alpha \iota$ of $10: 2$ as divorce, then proceed to translate $\dot{\alpha} \pi 0 \lambda \hat{v} \sigma \alpha \iota$ of 10:4 as either "put away," "repudiate," "send away," "let [her] go," "forsake," "leave," or "dismiss" in order to avoid the cacophonic "write a certificate of divorce and to divorce."

The inconsistency in which $\dot{\alpha} \pi \circ \lambda \dot{v} \omega$ and derivatives are translated, in and of themselves, shows that the terms are not synonymous or interchangeable with "divorce." If these terms, on the other hand, are considered synonymous, what are the dynamics within the grammatical, syntactical, and literary context that would allow a rendition of a Greek word to mean different things within the same structure?

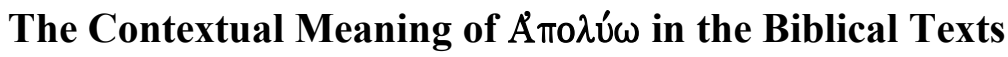

The following exercise, which involves the study of the crux word traditionally interpreted and/or translated "to divorce" ( $\dot{\alpha} \pi 0 \lambda \dot{v} \omega)$, is to attempt to determine if the translation and/or interpretation is consistent within the Markan narrative on "divorce."

The verb $\dot{\alpha} \pi 0 \lambda \dot{v} \omega$ is derived from the preposition $\dot{\alpha} \pi o ́$ (“from”) and the verb $\lambda \dot{v} \omega$ ("to untie," "to loosen," "to set free"). 'Aподví, in paradigm form, does not appear in the NT. Derivatives of $\ddot{\alpha} \pi 0 \lambda u ́ \omega$ in the "divorce" passages of the NT (Mark 10:2-12, Matt 19:2-9, and Luke 16:18) appear a total of sixteen times. They are: $\dot{\alpha} \pi \circ \lambda \hat{v} \sigma \alpha \iota$ (11 times), $\dot{\alpha} \pi 0 \lambda \dot{v} \sigma n$ (5 times), and $\dot{\alpha} \pi 0 \lambda \dot{\sigma} \sigma \alpha \sigma \alpha$ (once). The NT also contains twenty-three other 
instances of derivatives of $\dot{\alpha} \pi 0 \lambda \dot{v} \omega$ outside the divorce passages, none of which contain the inherent meaning, nor are they so translated "to divorce." 27 Justification for this exercise is called for because of the broad manner in which this key word and its derivatives are translated by different Bible versions and to verify whether the grammatical structure in which the word is found warrants a translation "to divorce."

In an exhaustive analysis of the meaning of the Greek term $\dot{\alpha} \pi 0 \lambda \dot{u} \omega$ and derivatives, the Thesaurus linguae graecae $(T L G)^{28}$ shows that the Judeo-Hellenistic and the classical Greek literature of the first century BCE contains close to three hundred occurrences, while the extra-Biblical Greek literature of the first century CE contains it more than four hundred times. At the same time, the Patristic, the Apocryphal, the semiChristian, and pagan literature of the second century CE uses the derivatives of $\dot{\alpha} \pi \circ \lambda \dot{v} \omega$ over eight hundred times. ${ }^{29}$ In those instances where the English translations of GreekRoman sources translate $\dot{\alpha} \pi 0 \lambda \dot{v} \omega$ as divorce, the BDAG contains a notation that "this [use] is in accord not with Jewish ... but with Greco-Roman custom.. ${ }^{30}$ In the following section, however, I analyze the derivatives of $\dot{\alpha} \pi \mathrm{o} \lambda \dot{v} \omega$ in the LXX.

\footnotetext{
${ }^{27}$ Tables 2-6 above dealt with the use of the derivatives of $\dot{\alpha} \pi 0 \lambda \dot{u} \omega$ in the "divorce" sayings of Mark and Matthew. A quick perusal of Hermeneutika BibleWorks 8.0 will verify the wide variety of ways in which these derivatives are used and/or translated by different Bible versions throughout the NT.

${ }^{28}$ See Maria C. Pantelia, Project Director, Thesaurus Linguae Graecae, CD ROM, no. E (Irvine: University of California, 1999).

${ }^{29}$ See the appendix.

${ }^{30}$ BDAG, s.v. "divorce"; cf. Dionysius, Antiquities, 2.25.7, and Diodorus Siculus, Library of History, trans. Charles Henry Oldfather (Cambridge, MA: Harvard University Press. 1933-1967), 12.18.1.2. Here in Diodorus, a woman " $\alpha \pi \mathrm{\pi} \lambda \nu \omega$ " her husband, which Cary translates "divorced" since in ancient Roman law, to leave was to divorce. For more, see chapter 3.
} 


\section{The Septuagint (LXX)}

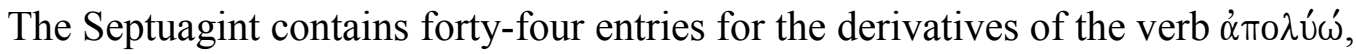
providing us a window as to how Alexandrian Greek-speaking Jews may have used it. Of those forty-four entries of cognate words related to $\alpha$ mo $\lambda \dot{v} \omega$, only one parallels the Greek terms found in the divorce passages of the NT: ( $\alpha \pi 0 \lambda \hat{v} \sigma \alpha \iota)$ translated "to take me out

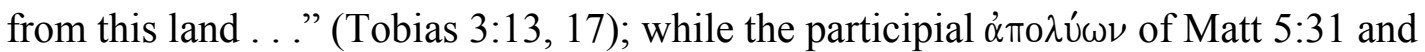
Luke 16:18 appears twice. Here Daniel berates the elders for their condemnation of Susanna (1:53), "for thou hast pronounced false judgment, and hast condemned the innocent, and hast let the guilty go free $\left(\dot{\alpha} \pi \circ \lambda u^{\prime} \omega \nu\right),{ }^{, 31}$ and in Ps 16:14, wrongly translated "to destroy." The majority of occurrences are found in Maccabees (17 times); Tobit (6 times), ${ }^{32}$ Sirach or Ecclesiasticus (2 times), Susanna (2 times), Wisdom of Solomon (2 times), 1 Esdras (once), Proverbs (once), and Odes (once). Table 8 below shows how the derivatives of $\dot{\alpha} \pi \circ \lambda u^{\prime} \omega$ are variably translated in the Septuagint, Spanish, and English Bibles. $^{33}$

\footnotetext{
${ }^{31}$ Lancelot C. L. Brenton, trans., The Septuagint with Apocrypha: Greek and English, Regency Reference Library (Grand Rapids, MI: Zondervan, 1988).

${ }^{32}$ Tobias has two more entries in the critical apparatus of 3:6 and 3:13. There, however, it is Sarah, rather than Tobit, who uttered the prayers. In 3:6, Tobit's prayer uses the aorist, infinitive, passive

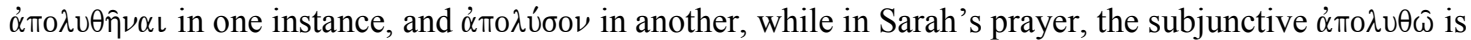
used. The same occurs in 3:13, where Tobit again uses $\dot{\alpha} \pi \circ \lambda \cup \theta \hat{\eta} \nu \alpha \iota$, while Sarah uses the aorist, infinitive $\dot{\alpha} \pi 0 \lambda \hat{v} \sigma \alpha \iota$.

${ }^{33}$ See Septuaginta: id est Vetus Testamentum Graece Iuxta LXX Interpretes, ed. Alfred Rahlfs (Stuttgart: Württembergische Bibelanstalt, 1971); cf. Hermeneutika BibleWorks 8.0.
} 
Table 8. Åno $\lambda u ́ \omega$ and derivatives in the $\mathbf{L X X}$

\begin{tabular}{|c|c|c|c|c|c|c|}
\hline \multicolumn{7}{|c|}{ Section 1} \\
\hline $\begin{array}{l}\text { To Leave/ } \\
\text { Depart }\end{array}$ & $\begin{array}{l}\text { To Take } \\
\text { Out/From }\end{array}$ & To Deliver & $\begin{array}{l}\text { To Set/ Go } \\
\text { Free/ Let } \\
\text { Go }\end{array}$ & $\begin{array}{l}\text { To Release/ } \\
\text { Dismiss/ } \\
\text { Discharge }\end{array}$ & $\begin{array}{l}\text { To Send/ } \\
\text { Put Away/ } \\
\text { Back }\end{array}$ & To Die \\
\hline 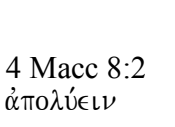 & $\begin{array}{l}2 \text { Macc 7:9 } \\
\dot{\alpha} \pi 0 \lambda \cup ́ \epsilon\llcorner\zeta\end{array}$ & $\begin{array}{l}\text { Odes of Sol. } \\
13: 29 \\
\dot{\alpha} \pi 0 \lambda \cup ́ \in L S\end{array}$ & $\begin{array}{l}2 \operatorname{Macc} 10: 21 \\
\dot{\alpha} \pi 0 \lambda \dot{\sigma} \sigma \alpha \nu \tau \in \varsigma\end{array}$ & $\begin{array}{l}\text { 3. Macc 6:28 } \\
\dot{\alpha} \pi 0 \lambda \nu ́ \sigma \alpha \tau \epsilon\end{array}$ & 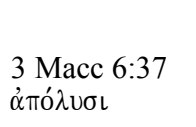 & $\begin{array}{l}\text { Num 20:29 } \\
\dot{\alpha} \pi \in \lambda \dot{v} \theta \eta\end{array}$ \\
\hline $\begin{array}{l}\text { Gen 15:2 } \\
\dot{\alpha} \pi 0 \lambda \dot{v} 0 \mu \alpha \iota\end{array}$ & $\begin{array}{l}\text { Tobit 3:13 } \\
\dot{\alpha} \pi 0 \lambda v \theta \hat{\eta} \nu \alpha \iota\end{array}$ & $\begin{array}{l}4 \text { Macc 11:13 } \\
\dot{\alpha} \pi 0 \lambda \cup ́ \in \sigma \theta \alpha \iota\end{array}$ & $\begin{array}{l}1 \text { Macc 10:29 } \\
\dot{\alpha} \operatorname{\pi o\lambda } \dot{\omega} \omega\end{array}$ & $\begin{array}{l}3 \operatorname{Macc} 5: 34 \\
\dot{\alpha} \pi^{\prime} \lambda \cup \sigma \alpha \nu\end{array}$ & 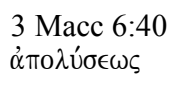 & \\
\hline $\begin{array}{l}1 \text { Macc } 3: 32 \\
\dot{\alpha} \pi^{\prime} \hat{\lambda} \nu \sigma \sigma \epsilon\end{array}$ & $\begin{array}{l}\text { Tobit 3:6 } \\
\dot{\alpha} \pi 0 \lambda v \theta \hat{\omega}\end{array}$ & $\begin{array}{l}2 \operatorname{Macc} 6: 22 \\
\dot{\alpha} \pi 0 \lambda \cup \theta \hat{n}\end{array}$ & $\begin{array}{l}\text { Sus 1:53 } \\
\dot{\alpha} \pi 0 \lambda \hat{v} \omega \nu\end{array}$ & $\begin{array}{l}2 \operatorname{Macc} 4: 47 \\
\dot{\alpha} \pi^{\prime} \lambda \cup \sigma \epsilon\end{array}$ & $\begin{array}{l}1 \text { Esd 9:36 } \\
\dot{\alpha} \pi \pi^{\prime} \lambda v \sigma \alpha \nu\end{array}$ & \\
\hline \multirow[t]{6}{*}{$\begin{array}{l}\text { Tobit 10:12 } \\
\dot{\alpha} \epsilon^{\prime} \lambda \cup \sigma \epsilon\end{array}$} & $\begin{array}{l}\text { Tobit } 3: 17 \\
\dot{\alpha} \pi 0 \lambda \hat{v} \sigma \alpha \iota\end{array}$ & $\begin{array}{l}\text { Tobit 3:6 } \\
\dot{\alpha} \pi \mathrm{v} \nu \cup \hat{\eta} \nu \alpha \iota\end{array}$ & $\begin{array}{l}2 \operatorname{Macc} 12: 25 \\
\dot{\alpha} \pi^{\prime} \lambda u \sigma \alpha \nu\end{array}$ & $\begin{array}{l}4 \text { Macc 12:8 } \\
\dot{\alpha} \pi \epsilon \lambda \dot{v} \sigma \alpha \tau \epsilon\end{array}$ & $\underset{\alpha \pi^{\prime} \epsilon ́ \lambda \cup \sigma \epsilon}{\operatorname{Macc} 11: 38}$ & \\
\hline & & $\begin{array}{l}2 \text { Macc 6:30 } \\
\dot{\alpha} \pi 0 \lambda \cup \theta \hat{\eta} \nu \alpha \iota\llcorner\end{array}$ & $\begin{array}{l}\text { Ps } 33: 1 \\
\dot{\alpha} \pi \epsilon \in \lambda \cup \sigma \in V\end{array}$ & & $\underset{\alpha \pi^{\prime} \in \dot{\lambda} \cup \sigma \epsilon}{2 \operatorname{Macc} 14: 23}$ & \\
\hline & & $\begin{array}{l}2 \text { Macc 12:45 } \\
\dot{\alpha} \pi \circ \lambda \cup \theta \tilde{\eta} \nu \alpha \iota\end{array}$ & & & $\begin{array}{l}\text { Sus 1:36 } \\
\dot{\alpha} \pi \pi^{\prime} \lambda v \sigma \sigma \epsilon\end{array}$ & \\
\hline & & & \multicolumn{4}{|l|}{ Section 2} \\
\hline & $\begin{array}{l}\text { To } \\
\text { Liberate/ } \\
\text { Set Free }\end{array}$ & To Retire & $\begin{array}{l}\text { To Judge } \\
\text { Innocent }\end{array}$ & $\begin{array}{l}\text { To Go Out } \\
\text { of }\end{array}$ & To Destroy & $\begin{array}{l}\text { To Root } \\
\text { Out }\end{array}$ \\
\hline & $\begin{array}{l}1 \text { Macc } 10: 43 \\
\dot{\alpha} \pi 0 \lambda \in \lambda \dot{v}- \\
\sigma \theta \omega \sigma \alpha \nu\end{array}$ & $\begin{array}{l}\text { Exod 33:11 } \\
\dot{\alpha} \pi \in \lambda \dot{u} \in \tau o\end{array}$ & $\begin{array}{l}2 \operatorname{Macc} 4: 47 \\
\dot{\alpha} \pi \in \lambda \dot{v} \theta \eta \sigma \alpha \nu\end{array}$ & $\begin{array}{l}\text { Sir 27:19 } \\
\dot{\alpha} \pi^{\prime} \lambda \lambda^{\prime} \cup \alpha \varsigma\end{array}$ & $\begin{array}{l}\text { Ps 16:14 } \\
\dot{\alpha} \pi \in \lambda \dot{v} \omega v\end{array}$ & $\begin{array}{l}\text { Sir } 49: 7 \\
\dot{\alpha} \pi \in \lambda \dot{U} \in L \nu\end{array}$ \\
\hline
\end{tabular}

One of the derivatives of $\dot{\alpha} \pi 0 \lambda v^{\prime} \omega$ as found in the LXX has been traditionally interpreted to mean "divorce" in commentaries of its counter-narrative in Ezra 10. This reference is found in 1 Esd 9:36 where Jewish returnees from Babylon had married non- 
Jewish women. ${ }^{34}$ Considered an abomination by the religious leaders, they were ordered to "divorce" $\left(\dot{\alpha} \pi \pi^{\prime} \lambda \nu \sigma \alpha \nu\right)$ them. Á $\pi^{\prime} \dot{\epsilon} \nu \sigma \alpha \nu$ is taken to mean "to divorce" based on what Shecaniah said that such divorces are "according to the counsel of my lord and of those who tremble at the commandment of our God; and let it be done according to the law" (Ezra 10:3). ${ }^{35}$

Supposedly, such command to divorce is found in Torah. Though many have rightly argued that Torah contains no specific command to divorce, but only a concession, ${ }^{36}$ what I find interesting is that in canonical Ezra, where the story is

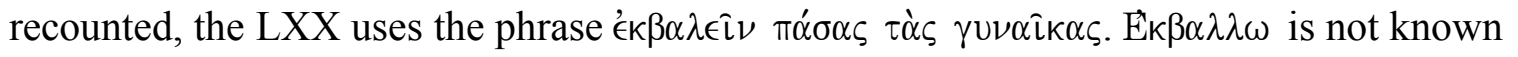
anywhere to mean divorce, but a simple act of expulsion. Without a letter of divorce, it is simply that, an expulsion. ${ }^{37}$ In 10:19 we find the term 'ं $\xi \in \nu^{\prime} \in \mathcal{\prime} \gamma \alpha \mathrm{L}$, the aorist, active, infinitive of '́k $\kappa \phi^{\prime} \rho \omega$. Though uncommon in the NT (it appears only once in infinitive form in Acts 5:15), it means to bring out, to put out, to carry out, to depart, to send out, ${ }^{38}$

\footnotetext{
${ }^{34}$ See Juha Pakkala, Ezra the Scribe: The Development of Ezra 7-10 and Nehemiah 8 (New York: Walter de Gryter, 2004), 95; Lester L. Grabbe, A History of the Jews and Judaism in the Second Temple Period (Edinburgh: T \& T Clark, 2004), 121; Mark A. Throntveit, Ezra-Nehemiah (Louisville, KY: John Knox Press, 1992), 143.

${ }^{35}$ As to Shecaniah's statement, Najman claims that he does so at a time when there were no distinctions between reading the Torah, quoting the Torah, or even interpreting Torah, "thus Ezra could not offer authoritative interpretation without claiming that this reading was Mosaic in origin." Hindy Najman, "Seconding Sinai: The Development of Mosaic Discourse in the Second Temple," Journal for the Study of Judaism in the Persian, Hellenistic, and Roman Periods Supplement 77 (Atlanta: SBL, 2003), 113; cf. Michael Fishbane, Biblical Interpretation in Ancient Israel (Oxford: Clarendon, 1986), 115-116.

${ }^{36}$ Among others, see Polaski and Polaski, "Listening," 595; Healy, Mark, 196; Stein, Mark, 456; Davidson, Flame, 384-387; Nydam, "Messiness," 219-220; Robert W. Herron, "Mark's Jesus on Divorce: Mark 10:1-12 Reconsidered," Journal of the Evangelical Theological Society (JETS) 25 (1982): 274.

${ }^{37}$ See Davidson, Flame, 321-322.

${ }^{38}$ See Wesley J. Perschbacher, ed., The New Analytical Greek Lexicon (Peabody, MA: Hendrickson, 1990), s.v. "€кф́́ $\rho \omega$ "; cf. James H. Moulton and George Milligan, The Vocabulary of the Greek Testaments (London: Hodder and Stoughton, 1952), 200.
} 
and even to expel. ${ }^{39}$ As a derivative of $\phi \in ́ f \omega$, "the basic sense is to drive out men, cattle." ${ }^{40}$ In canonical Ezra, the actions reflected seem to imply a procedure to rid of these foreign women whose marriages with the Israelites were considered invalid. ${ }^{41}$

As a matter of interest I have chosen to compare a term the NIV consistently translates "to divorce" with Brenton's translation of the LXX:

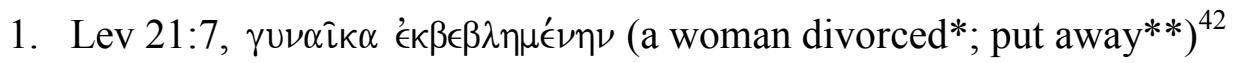

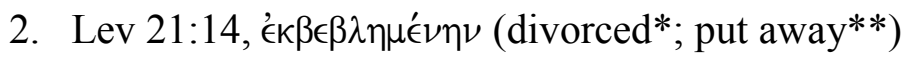

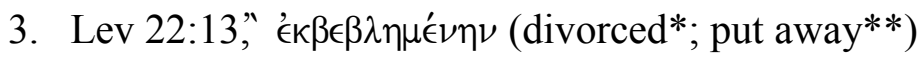

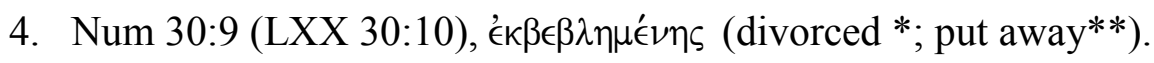

The term used here translated "to divorce" (NIV) and "to put away" (Brenton), is a derivative of ' $\epsilon \kappa \beta \alpha \alpha \lambda \lambda \omega$, to drive out, expel, throw out more or less forcibly. ${ }^{43}$

The $T L G$ produced no results in which ' $\mathrm{\epsilon} \kappa \beta \alpha^{\prime} \lambda \lambda \omega$ or its derivatives are known to have been used for divorce. Laws written before Deut 24 do not seem to envision that formal divorces had actually occurred. The actions there seem to reflect those in which

\footnotetext{
${ }^{39}$ Leslie C. Allen and Timothy S. Laniak, Ezra, Nehemiah, Esther, New International Bible Commentary, ed. Robert L. Hubbard and Robert K. Johnston (Peabody, MA: Hendrickson, 2003), 81.

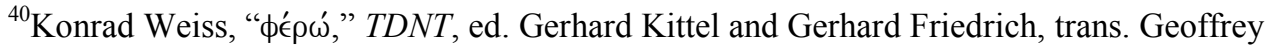
Bromiley (Grand Rapids, MI: Eerdmans, 1964-1976), 9:56.

${ }^{41} \Delta\llcorner\alpha \sigma \tau \dot{\alpha} \lambda \eta \tau \epsilon$ is used "to separate" ("yourselves from the peoples of the land and from the foreign wives," Ezra 10:11) and ' $\xi^{\prime} \in \nu^{\prime} \in \gamma \kappa \alpha \iota$ for "to send away their wives" (Ezra 10:19). No specific Mosaic terminology for "divorce" is found in the text. For a comprehensive treatment of the "invalid" marriages in Ezra's time, see Davidson, Flame, 320-325, 417.

${ }^{42}$ Translations in brackets with one asterisk $\{*\}$ belong to The Holy Bible: New International Version Containing the Old and New Testaments (Grand Rapids, MI: Zondervan, 1989); while those with two asterisks $\{* *\}$ are from Brenton, The Septuagint.

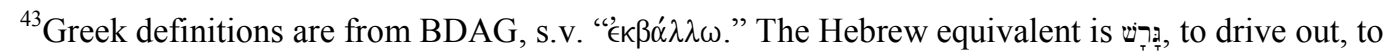
expel, to cast out, to drive away. See Francis Brown, S. R. Driver, and Charles A. Briggs, The New Brown, Driver, and Briggs Hebrew and English Lexicon of the Old Testament (Grand Rapids, MI: Baker, 1981),

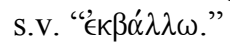


these women were simply expelled from the husbands' house. In fact, the Mosaic statement became expedient in view of some of these apparent abuses.

In the statements written right before and after the Mosaic pronouncement of Deut 24, we find the following:

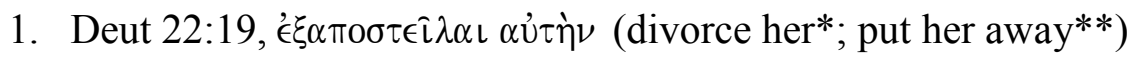

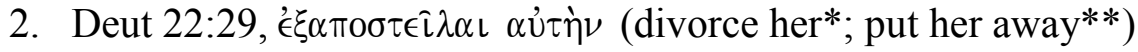

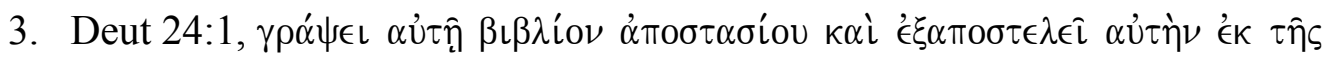
oíkí $\alpha$ Ủंôิ (write her a certificate of divorce;* write her a bill of divorcement** and send her from his house, ${ }^{*}$ and send her away out of his house**)

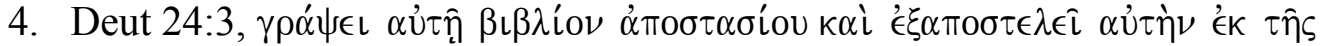
oíkí $\alpha$ Ủंôิ (write her a certificate of divorce, ${ }^{*}$ write her a bill of divorcement** and send her from his house, ${ }^{*}$ and send her away out of his house**)

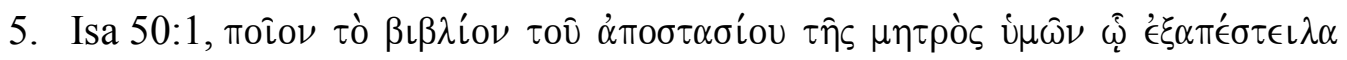

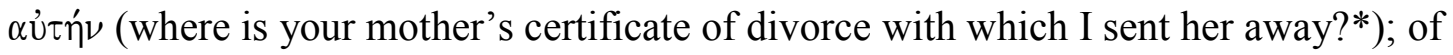
what kind is your mother's bill of divorcement by which I put her away?**)

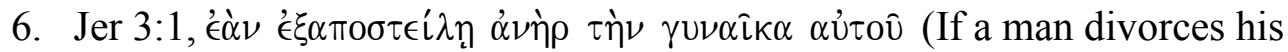
wife;* and if a man put away his wife**)

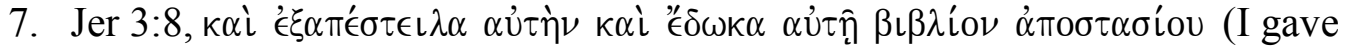
faithless Israel her certificate of divorce and sent her away,* and I put her away, and gave into her hands a bill of divorcement**)

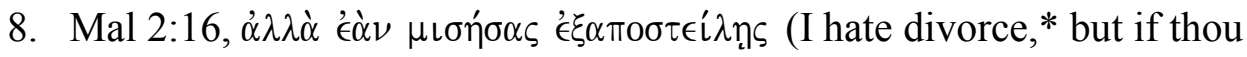
shouldest hate thy wife and put her away**). 
It is interesting to note how the NIV interchangeably gives different renditions of

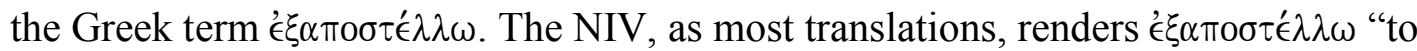

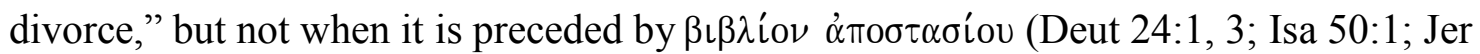
3:8). In such cases the translation changes to "to send her away." The terms translated "to divorce" (NIV) and "to send or put away" (Brenton) are derivatives of '́ $\xi \alpha \alpha \pi \sigma \tau \tau^{\prime} \lambda \lambda \omega$, in the texts above.

A perusal of the $T L G$ produced no results in which ${ }^{\xi} \xi \alpha \pi \sigma \sigma \tau \dot{\epsilon} \hat{\epsilon} \lambda \omega$ or derivatives are used in a context of a formal/legal divorce. The grammatical structure, however, as

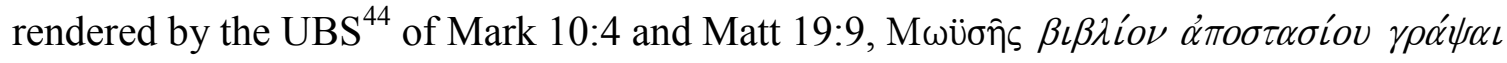

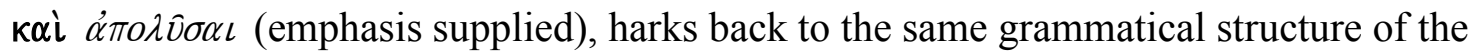

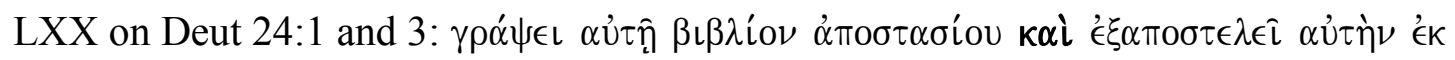

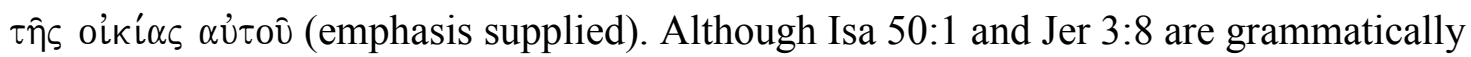
structured somewhat different from Deut 24:1 and 3, in these texts ${ }^{\prime} \xi \alpha \pi 0 \sigma \tau \tau^{\prime} \lambda \lambda \omega^{45}$ comes as the "natural" consequence of a letter of divorce once it has been placed in the wife's hand. A bird's-eye view of the grammatical structure (emphasis supplied) of these texts looks like this:

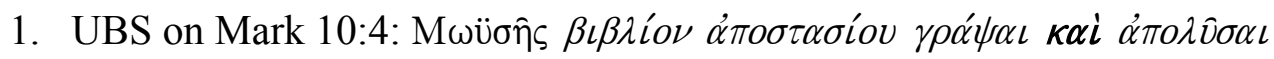

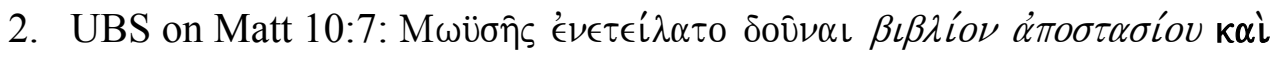

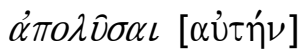

${ }^{44}$ The Greek New Testament, 4th rev. ed., ed. Kurt Aland, Barbara Aland, Matthew Black, Carlo M. Martini, Bruce M. Metzger, and Allen Wikgren (New York: United Bible Societies, 1993).

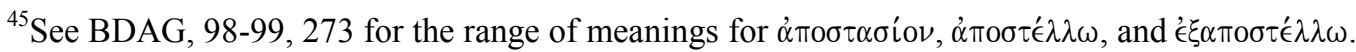
The Hebrew term for this latter word is "to "to send away, to send, to let go, to expel." See, Brown, Driver, and Briggs, s.v. " $€ \xi \alpha \pi 0 \sigma \tau \in \epsilon \lambda \lambda \omega$." 


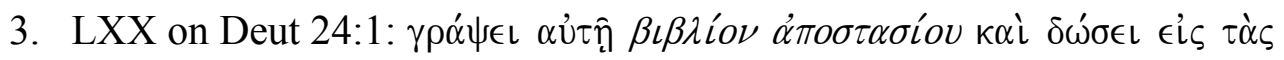

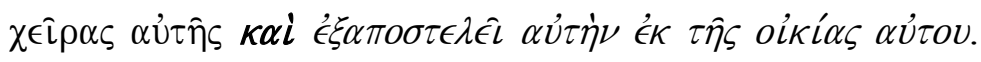

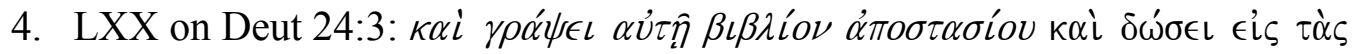

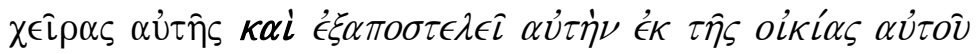

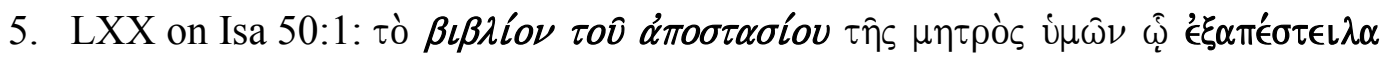
$\alpha u ̉ \tau \eta \dot{\nu}$

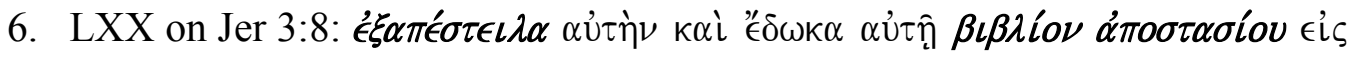

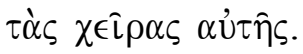

Although the NT Greek text (UBS) uses $\dot{\alpha} \pi 0 \lambda \hat{v} \sigma \alpha \iota$ and the OT Greek text (LXX) uses ${ }^{\prime} \xi \alpha \pi$ $\xi \tau \tau^{\prime} \hat{\epsilon} \lambda \omega$, the corresponding elements of the Mosaic statement in both Greek versions are not hard to miss. A perfunctory analysis of the Mosaic statement as it appears in both Deut 24:1 and Mark 10:4 seems to indicate that "to divorce"

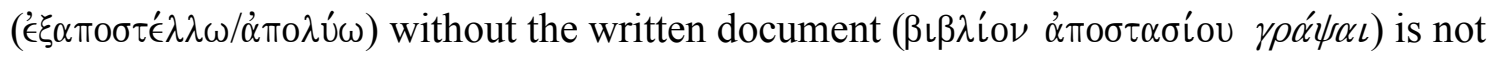
truly a divorce as "Moses commanded," but rather a mere repudiation, expelling or "send[ing] her out of his house." The expelling of the woman from her house proved that a divorce had taken place only as she went out with a document in hand that stated, "Lo, thou art free to marry any man."46

${ }^{46} m$. Git. 9.3. R. Judah framed the letter of divorce thus: "Let this be from me thy writ of divorce and letter of dismissal and deed of liberation, that thou mayest marry whatsoever man thou wilt." But that "the essential formula in a writ of emancipation is, 'Lo, thou art a freedwoman: Lo, thy belongest to thyself." The Mishnah, trans. Herbert Danby (London: Oxford University Press, 1983), 319. 


\section{The New Testament}

The anarthrous infinitive $\alpha \pi 0 \lambda \hat{v} \sigma \alpha \iota$, variously translated "to divorce," "to put away," "to send away," "to dismiss," "to leave," "to set free," "to let go," and "to repudiate" appears five times in the "divorce" passages of Mark $(10: 2,4)$ and Matthew $(19: 3,7,8)$. It is additionally found six more times in the NT (Matt 1:19; 15:32; Luke 23:20; John 19:10, 12; Acts 28:18).

In Matt 1:19 it is used in reference to Joseph who "resolved to divorce ( $\dot{\alpha} \pi 0 \lambda \hat{v} \sigma \alpha \iota)$ her [Mary] quietly $\left(\lambda \alpha^{\prime} \theta \rho \alpha\right)$ " so as not to defame her. The context is generally understood as referring to Joseph's breaking off of his betrothal with Mary, not his "divorce" from her. The lexical entry in $\mathrm{BDAG}^{47}$ renders two possibilities for $\lambda \alpha^{\prime} \theta \rho \alpha$ : (1) "secretly," and (2) "without the knowledge of." Since there are no instances of secret divorces in the NT or Jewish writings of the same period, the translation of $\lambda \alpha^{\prime} \theta \rho \alpha \alpha^{\alpha} \pi 0 \lambda \hat{v} \sigma \alpha \iota$, "to divorce secretly," is awkward and unhistorical. ${ }^{48}$

As to Matt 15:32, most translations render $\alpha$ $\pi 0 \lambda \hat{v} \sigma \alpha \iota$, "to send away." It is used in the context of the feeding of the four thousand where Jesus was "unwilling to send them away hungry." A third occurrence is found in Luke 23:20 in the context of Pilate's desire

${ }^{47} \mathrm{BDAG}$, s.v. “ $\lambda \dot{\alpha} \theta \rho \alpha . "$

${ }^{48}$ Jewish law provided two ways in which a man could divorce his wife: (1) a letter written and signed in the presence of two witnesses, and (2) before a scribe. A written document was required to legalize either of these transactions. A so-called "private" divorce was originally intended for Jews living outside Israel and who did not have access to a scribe as described in b. Git. 2a-5b, Ket 6a-9b; m. Git 8.9, San 7.3.9. There are no records to indicate that betrothals were broken through divorce, much less through a "secret divorce." A $\pi 0 \lambda \hat{v} \sigma \alpha \iota$ in Matt 1:19 appears to point to the mere break-up of an engagement, rather than a divorce proper; see p.130, n.51. 
"to release" ( $\dot{\alpha} \pi 0 \lambda \hat{v} \sigma \alpha \iota)$ Jesus. ${ }^{49}$ John 19:10, 12 provides us with two more uses of $\dot{\alpha} \pi 0 \lambda \hat{\sigma \alpha} \alpha$ related to the same events of Jesus' trial before Pilate. In both instances $\dot{\alpha} \pi 0 \lambda \hat{v} \sigma \alpha \iota$ is translated "to free" by the NIV, where in the previous instance (in Luke), the same NIV translated them "to release." In Acts 28:18 the use of $\dot{\alpha} \pi 0 \lambda \hat{v} \sigma \alpha \iota$ is found in Paul's address to Jewish leaders in Rome. Here Paul narrates his trial in Jerusalem where after having been handed over to the Roman authorities, "they wanted to release me."

The aorist subjunctive $\dot{\alpha} \pi \mathrm{\nu} \lambda \dot{u} \sigma \emptyset$ is found five times in the NT, two of which are outside "divorce" passages, neither of which are translated "to divorce" in any version. In Matt 14:22, again, it is in the context of the feeding of the multitude. Here again Jesus refused to send the crowds away hungry. The second one is found the Pilate/religious leaders/crowd encounter (Mark 15:11). Again, it is translated "to release."

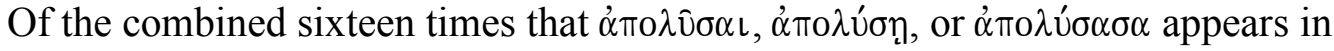
the NT, only six times (Matt 5:31; 19:3, 7, 8; Mark 10:2, 4) are they translated "to divorce" in the NRS version. Of the total of forty-three times that derivatives of $\dot{\alpha} \pi 0 \lambda \dot{u} \omega$ appear in the NT, only ten times are they variably translated "to divorce" by most translations. ${ }^{50}$

As noted above, the NT's use of $\dot{\alpha} \pi 0 \lambda \hat{v} \sigma \alpha L$ in the context of divorce comes only in the grammatically structured phrase (in both Mark 10:4 and Matt 19:7), $\beta\llcorner\beta \lambda$ iov

\footnotetext{
${ }^{49}$ Derivatives of $\dot{\alpha} \pi 0 \lambda \dot{v} \omega$ are found four more times in Luke 23:16-25 in the dialogue between Pilate, the religious leaders, and crowd: 23:16 and 22, "I will therefore chastise him [Jesus] and release him $\left(\dot{\alpha} \pi \circ \lambda v^{\prime} \sigma \omega\right)$," in the context as to whether "to release" Barabbas or Jesus; $23: 18$, "But they all cried out together, "away with this man, and release ( $\left.\dot{\alpha} \pi{ }^{\prime} \lambda \nu \sigma o v\right)$ to us Barabbas"”; $23: 25$, "He released $\left(\dot{\alpha} \pi \epsilon^{\prime} \lambda \nu \sigma \in \nu\right)$ the man [Barabbas]."

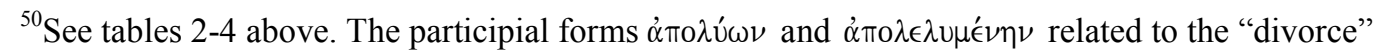
sayings are not found in Mark, but are found in the isolated "divorce" statements of Matt 5:31-32

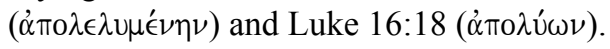




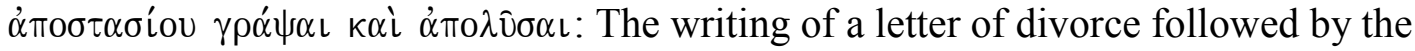
release or the expulsion from the home or sending her away from his house. The structural analysis above on the Markan pericope on "divorce" demonstrates that a mere separation or release of a wife $(\dot{\alpha} \pi 0 \lambda \hat{v} \sigma \alpha \iota)$ is implied in the original pharisaical question (Mark 10:2; Matt 19:3) without the benefit of the written letter of divorce, which in turn elicits Jesus' loaded question: “What did Moses command?" Whence the reply: "Moses permitted a man to write a certificate of divorce and [consecutively] send her away" $(10: 4$, NAS $)$.

\section{Term(s) for Divorce in the First Century}

\section{In Extra-Biblical Sources}

What are, then, the predominant Greek terms used for divorce during the first century CE? The dominical saying in the Synoptics contains derivatives of $\dot{\alpha} \pi 0 \lambda \dot{v} \omega$, translated "to divorce" by most Bible translators. A derivative of this verb (ं் $\pi 0 \lambda \hat{v} \sigma \alpha \iota)$ appears in Matthew's infancy narrative in which Joseph decides (wrongly translated) ${ }^{51}$ "to divorce" Mary because of her suspected infidelity (1:19; cf. Deut 22:13-21). Joseph Fitzmyer, arguing from "some new Palestinian evidence," purports to "put

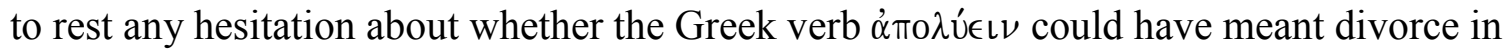
the Greek of Palestine.” Fitzmyer cites Mur 115.3-4 from cave II in which he alleges that

\footnotetext{
${ }^{51}$ Jacob Neusner states: "As far as I am concerned, neither the Mishnah nor any Talmudic tractate that I am aware of speaks of 'private divorces,' so I would not know what Matthew or his interpreters/translators may be talking about." Personal electronic communication with the author, June 21, 2006. Neusner goes on to say that he assumes that Joseph most likely dissolved the betrothal by secretly returning the Jewish get (dowry), but not divorce.
} 


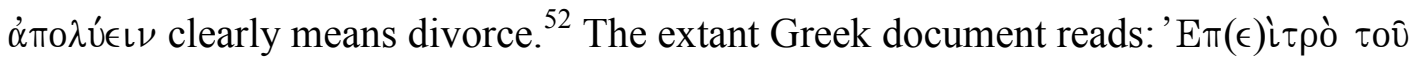

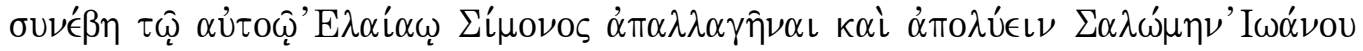
$\gamma \alpha \lambda \gamma o u \lambda \alpha{ }^{53}$ Fitzmyer translates it as follows: "since it happened earlier to the same Elaios (son) of Simon to become estranged and to divorce Salome (daughter) of John Galgoula. ${ }^{54}$ Fitzmyer contends that this interpretation is supported by the Murabba'at Aramaic inscription. A verbatim citation from the extant source reads: מרים ברת יהונתן Fitzmyer translates this as: "I, Joseph son of Naqsan, repudiate and divorce you, my wife Miriam, daughter of Jonathan." To "repudiate and divorce" (תרך from the rand iמתרך) is the

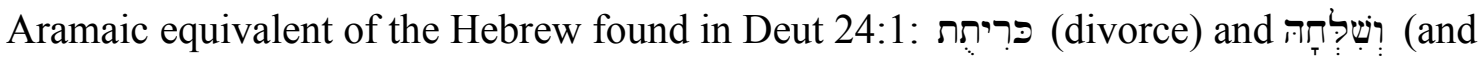

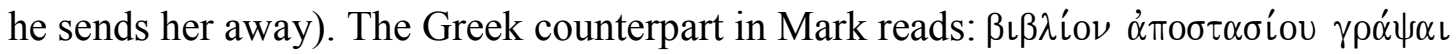
$\kappa \alpha \grave{\alpha} \pi 0 \lambda \hat{v} \sigma \alpha \iota$ (to write a certificate of divorce and to send away [from his house], Mark

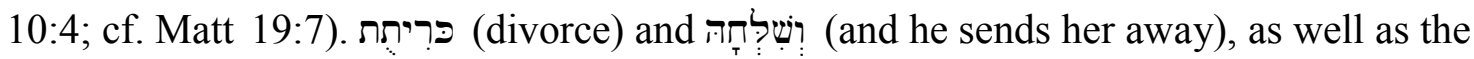
Greek construction, are consecutive actions. Fitzmyer is at his weakest precisely at the point where he would want to be the strongest.

\footnotetext{
${ }^{52}$ Fitzmyer, "Matthean Divorce," 212. Fitzmyer argues that $\dot{\alpha} \pi 0 \lambda \dot{\epsilon} \in \iota \nu$ as "divorce" is found in Greek writers such as Dionysius (Antiquities, 2.25.7) and Diodorus Siculus (Lib Hist 12.18.1.2). BDAG, however, states: "This [use] is in accord not with Jewish . . . but with Greco-Roman custom," s.v.

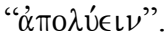

${ }^{53}$ Pierre Benoit, Jozef T. Milik, and Roland de Vaux, "Murabba'ât 115.3c-4a," Les Grottes de Murabba'ât, Discoveries in the Judaean Desert (Oxford: Clarendon, 1961), 2:248.

${ }^{54}$ Fitzmyer, "Matthean Divorce," 213. Emphasis supplied.

${ }^{55}$ Benoit et al., Les Grottes, 2:105 (Murabba'ât 19.2-4).

${ }^{56}$ Fitzmyer, "Matthean Divorce," 213. Emphasis supplied.
} 


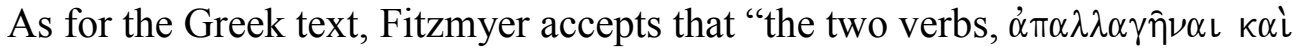
$\dot{\alpha} \pi \circ \lambda \dot{v} \in \iota \nu$ are probably an attempt to render into Greek the two Aramaic verbs customarily used in Jewish writs of "divorce," ${ }^{, 57}$ but fails to notice the actual Jewish divorce procedure by translating $\dot{\alpha} \pi \alpha \lambda \lambda \alpha \gamma \eta \hat{\eta} \alpha \iota$ as "estranged" and $\dot{\alpha} \pi 0 \lambda \cup \in \in L \nu$ as "divorce." The

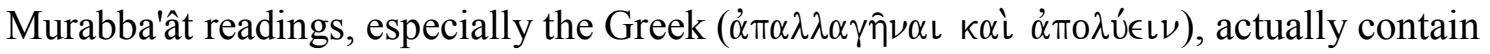
the divorce formula: $\alpha \pi \alpha \lambda \lambda \alpha \gamma \eta \hat{\eta} \nu \alpha$ followed by the consecutive conjunction $\kappa \alpha \dot{\imath}$ and the

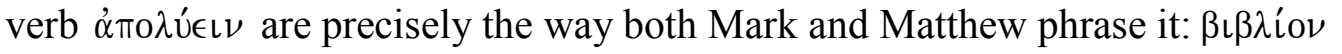

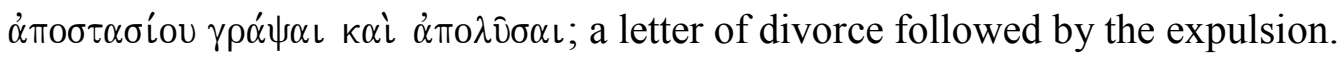

As to Fitzmyer's take, which is supposed to attest to the Greek text from Murabba'ât, he translates: "I, Joseph son of Naqsan, repudiate and divorce you." "Repudiate and divorce" do not appear to be redundant expressions (or hendiadys), rather, they contextually express both the act of a formal divorce followed by the expulsion or sending away from the home, as confirmed by the Greek construction of the

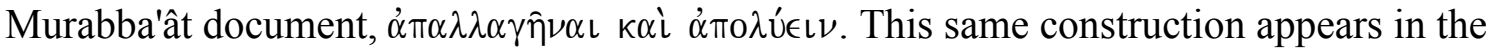
Markan account ${ }^{58}$ and according to Moulton and Milligan, $\dot{\alpha} \pi \alpha \lambda \lambda \alpha \gamma \eta \hat{\eta} \alpha \iota$ as "divorce" is attested in a number of the Greek papyri and Philo; ${ }^{59}$ while BDAG confirms that

${ }^{57}$ Fitzmyer, "Matthean Divorce," 213.

${ }^{58}$ Fitzmyer in effect changed the order "I, Joseph son of Naqsan, repudiate and divorce you" where

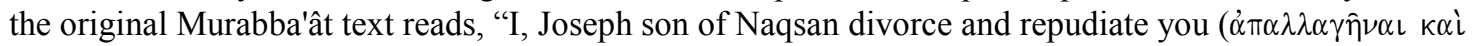

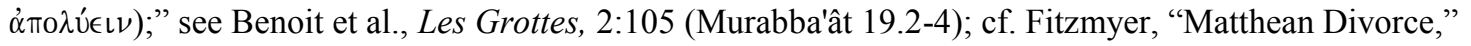
213.

${ }^{59}$ Moulton and Milligan, Vocabulary, 52; cf. David Daube, "The New Testament Terms for Divorce," Theology 47 (1944): 67. 
$\dot{\alpha} \pi 0 \lambda u^{\epsilon} \iota \nu$ "is not in accord with Jewish... but with Greek-Roman customs," ${ }^{60}$ being an act of expulsion.

The first Aramaic word (שבק) means to abandon, to desert, to leave alone. ${ }^{61}$ Interestingly enough, this verb is found in Matt 27:46 as expressed by Jesus while on the cross: "Eloi, Eloi, lema sabachthani?," My God, my God, why have you deserted me." The second Aramaic word (תרך from the root) may mean to drive out, to chase away, to expel, ${ }^{62}$ which means that in both the Greek and Aramaic texts from Muraba'at, the Jewish divorce procedure is distinguishable: divorcing and driving out; $\alpha \pi \alpha \lambda \lambda \alpha \gamma \eta \hat{\eta} \nu \alpha \iota$

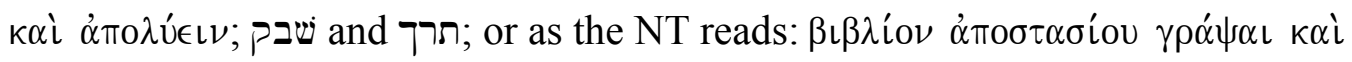
$\dot{\alpha} \pi 0 \lambda \hat{v} \sigma \alpha \alpha \iota$. These are all consecutive acts. But even supposing that $\dot{\alpha} \pi 0 \lambda \hat{U} \in \iota \nu$ were to mean divorce in the Greek text of Murabba'ât, this would be the only instance, and, a post-first-century one (dated ca. $124 \mathrm{CE}$ ) in which $\alpha \pi 0 \lambda v^{\prime} \in \nu$ in a text outside the NT would mean divorce. D. Daube observes that $\dot{\alpha} \pi 0 \lambda \dot{v} \in \iota \nu$ is so foreign to the idea of divorce that it "was introduced [into the NT] by someone not familiar with the Jewish ideas on the subject.",63

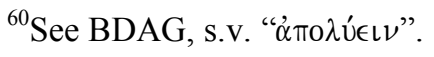

${ }^{61}$ See Michael Sokoloff, A Dictionary of Jewish Palestinian Aramaic (Jerusalem: Bar Ilan University Press, 1990), s.v. "שְׁבק".

${ }^{62}$ Ibid., 592; cf. Marcus Jastrow, A Dictionary of the Targum, the Talmud Babli and Yerushalmi and the Midrashic Literature (New York: Title Publishing House, 1943), s.v. "ומתרך"; and in Daube's view, this is the term a Jewish husband uses when he divorces his wife. "Terms for Divorce," 65.

${ }^{63}$ Daube, "Terms for Divorce," 66. 


\section{In Biblical Sources}

It has been said that 1 Cor 7:10-11 may contain the earliest attestation of the dominical saying on divorce. ${ }^{64}$ Here Paul uses the term $\chi \omega \rho\llcorner\sigma \theta \hat{\eta} \nu \alpha \iota$, generally translated "the wife should not separate from her husband" (NIV, RSV, NAB, JB, etc.). As an aorist passive infinitive, Fitzmyer points out that $\chi \omega \rho\llcorner\sigma \theta \hat{\eta} \nu \alpha \iota$ should be translated "a wife should not be separated from her husband" (emphasis supplied). ${ }^{65}$ Fitzmyer's proposition is somewhat ambiguous since this translation does not tell who is doing the separation. A

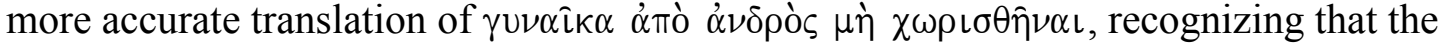
woman/wife is the passive agent of the action, should probably read, "a wife must not be divorced by her husband." 66

Speaking of the two terms Paul uses in 1 Corinthians, $\chi \omega \rho\llcorner\sigma \theta \hat{\eta} \nu \alpha \iota$ ( 7:10) and

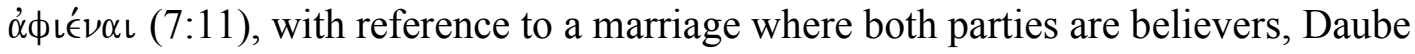
notes that Paul uses the intransitive $\chi \omega \rho\llcorner\sigma \theta \hat{\eta} \nu \alpha \iota$ of the wife who is divorcing her husband, and the transitive $\alpha \phi \iota^{\prime} \mathcal{\nu} \alpha \iota$ when the husband dismisses his wife. According to Daube, this is in perfect agreement with the Jewish idea on the subject. He also notes that in the next two verses $(7: 12-13)$ with reference to a marriage where only one party is a believer, Paul uses the transitive $\alpha \phi \iota^{\prime} \in \mathcal{v} \alpha \iota$ both of the dissolution of the marriage by the husband and its

\footnotetext{
${ }^{64}$ See Bartling, "Sexuality," 355-366; Charles K. Barrett, A Commentary to the First Epistle to the Corinthians (Peabody, MA: 1987), 162-165.

${ }^{65}$ Fitzmyer, "Matthean Divorce," 200. Emphasis supplied.

${ }^{66}$ Murphy-O'Connor renders the translation "the husband should not divorce his wife," apparently keeping the original intent of the dominical divorce logion. See Jerome Murphy-O'Connor, 1 Corinthians (New York: Doubleday, 1998), 602.
} 
dissolution by the wife. The latter application of ádiévoL is justified since the procedure is a non-Jewish one where no legal formalities were required under Roman law.

Again, a little further down (7:15), Daube notes that Paul uses $\chi \omega \rho i \zeta \in \tau \alpha \iota$ for the dissolution of the marriage by an unbelieving partner, husband or wife. Daube says that "no special justification is here needed, the term being a proper term for divorce." When

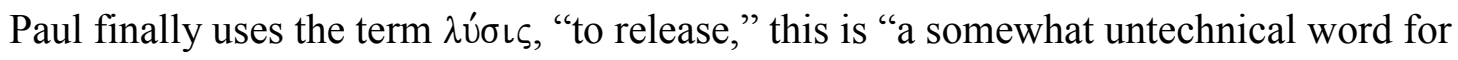
divorce," whether the husband is Jewish, Gentile, pagan or Christian in the admonition, "Are thou bound to a wife?, seek not release" (7:27) since "To be sure, divorce by mutual agreement, common throughout the Hellenistic world, may be described as 'expelling one another' whether the couple is Gentile or Jewish." ${ }^{, 67}$

Elliot makes an apropos observation that many commentators miss by pointing

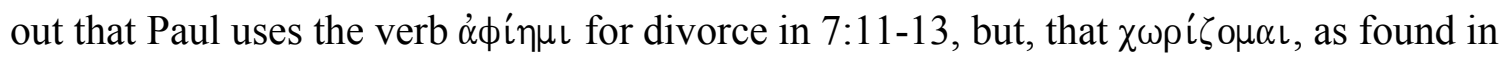
7:10-11, and 15, is a more forceful term for divorce of the Hellenistic period. Elliot sees Paul quoting Jesus in 1 Cor 7:10-11 and that although the evangelists use $\dot{\alpha} \pi \circ \lambda \dot{\omega} \omega$ and Paul $\dot{\alpha} \phi i \eta \eta \mu$, both terms are synonymous. ${ }^{68}$ Elliot states that "it is significant to note that

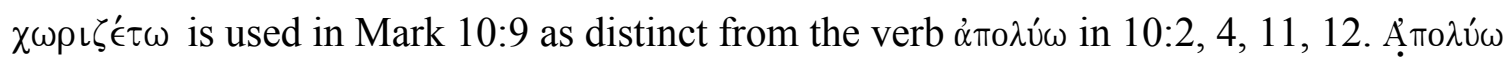
there corresponds with $\dot{\alpha} \phi i \eta \eta \iota$ in 1 Cor 7:11-13," which simply means to leave, to put

\footnotetext{
${ }^{67}$ Daube, Rabbinic Judaism, 362-363; cf. Gen. Rabbah 2.24; b. Qid. 58c for a Gentile divorce; Gen Rabbah 2:21 for a Jewish divorce; cf. Craig Keener, And Marries Another: Divorce and Remarriage in the Teaching of the New Testament (Peabody, MA: Hendrickson, 1991), 55, who observes that "marriage is dissolved simply by the unbelieving spouse abandoning the relationship."

${ }^{68}$ See J. K. Elliot, "Paul's Teaching on Marriage in 1 Corinthians: Some Problems Considered," NTS 19 (1973): 223. It is significant that $\chi \omega \rho \hat{\prime} \zeta \omega$ is used in Mark 10:9 as distinct from the verb $\dot{\alpha} \pi 0 \lambda \dot{v} \omega$ in $10: 2,4,11,12$. If $\dot{\alpha} \pi 0 \lambda \dot{v} \omega$ there corresponds with $\alpha \phi i \eta \eta \iota$ in 1 Cor 7:11-13 (224), then $\dot{\alpha} \pi 0 \lambda \dot{v} \omega$ simply means "to leave," "put away," "to dismiss," but not "to divorce."
} 
away, to dismiss, but not divorce. ${ }^{69}$ Fee correctly assesses that our search to find a clearly defined distinction in these two verbs "reflects our own urgencies for greater precision. Divorce in Greco-Roman culture could be 'legalized' by means of documents (for the upper classes); but more often it simply happened. In this culture divorce was divorce, whether established by a document or not." ${ }^{, 70}$

While $\dot{\alpha} \pi 0 \lambda \dot{u} \omega$ is the term translated "to divorce" by most Bible versions in the Synoptics, translators have rarely recognized the fact that during the Roman and Byzantine Periods $\chi \omega \rho^{\prime} \zeta \omega$ and $\delta\llcorner\alpha \chi \omega \rho i \zeta \omega$ are the terms used to describe the process of divorce. ${ }^{71}$ Pring posits that $\delta\left\llcorner\alpha \chi \omega{ }^{\prime} \zeta \omega\right.$ is the term used for divorce by Greek-speaking cultures up to modern times. ${ }^{72}$ Moulton and Milligan point out as well that $\chi \omega \rho i \zeta \omega$ is the term for divorce found in Greek marriage contracts. ${ }^{73}$ Interestingly enough, in the Modern Greek Bible of BibleWorks 8.0, the editors apparently assume that the Pharisaic confrontation revolved around the question of divorce. Rather than keeping $\dot{\alpha} \pi 0 \lambda \hat{v} \sigma \alpha \iota$ (USB), they use $\chi \omega \rho\llcorner\sigma \theta \hat{n}$ in Mark 10:2, 12 and Matt 5:32 and $\sigma u \gamma \chi \omega \rho \in \hat{\imath} \tau \alpha \iota$ in Matt 19:3.

Fitzmyer, who otherwise argues that $\dot{\alpha} \pi 0 \lambda \dot{v} \omega$ means "to divorce" in the Gospels, himself admits that $\chi \omega \rho i \zeta \omega$ is the most common term for divorce used by the Greek

\footnotetext{
${ }^{69}$ Elliot, "Paul's Teaching," 222; cf. I. Johannes. du Plessis, “The Ethics of Marriage according to Matt 5:27-32," Neotestamentica 1 (1967): 23, where it states that $\alpha$ mo $\lambda \dot{U} \in\llcorner\nu$ is not a legal term but has the meaning of 'loosen,' 'let go,' or 'free."' Cf. Procksh, “ $\lambda \dot{u} \omega$, , TDNT, 4:328-431.

${ }^{70}$ Gordon D. Fee, The First Epistle to the Corinthians, NICNT (Grand Rapids, MI: Eerdmans, 1991), 293.

${ }^{71}$ See E. A. Sophocles, Greek Lexicon of the Roman and Byzantine Periods: From BC 146 to AD 1100 (New York: Fredrick Ungar, 1957), 1:376; 2:1177. $\delta\llcorner\alpha \chi \omega \rho i \zeta \omega$.

${ }^{72}$ See J. T. Pring, comp., The Oxford Dictionary of Modern Greek (Oxford: Clarendon, 1982), s.v.

${ }^{73}$ Moulton and Milligan, Vocabulary, 696.
} 
writers of the classical and Hellenistic periods; ${ }^{74}$ whereas Catchpole asserts that "the authoritative language for divorce is quite explicit [as] evidenced in Hellenistic divorce

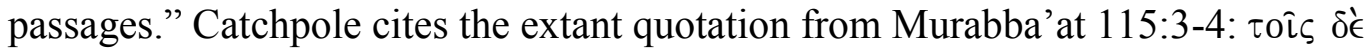

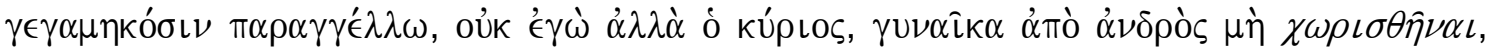

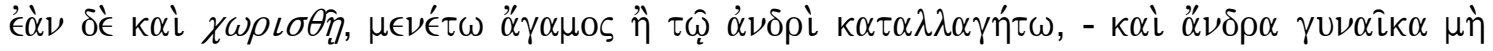
$\dot{\alpha} \phi \iota^{\prime} \in \mathcal{\nu} \alpha$ in which "attempts to find traces of [Mark 10], Matt 19 and 1 Cor 7 have failed.",75

\section{Summary and Conclusions}

The preceding analyses have allowed us to understand:

1. The Markan (10:1-12) pericope as a literary unit

2. The interconnectedness of the pericope from a literary-syntactical view

3. The inconsistent way in which various translations of the Bible translate the main word used for divorce

4. That $\dot{\alpha} \pi 0 \lambda \dot{u} \omega$ is hardly the preponderant word used for divorce in the century preceding and the century succeeding the NT period, but rather $\chi \omega \rho \imath \zeta \omega$ and $\delta\llcorner\alpha \chi \omega \rho i \zeta \omega$. A diachronic analysis of $\dot{\alpha} \pi 0 \lambda \hat{u} \omega$ has shown that this term was rarely used to mean divorce. ${ }^{76}$ And since "to divorce" has been the translators' term of choice of the Synpotic accounts, rather than the intended meaning of the original authors, it seems imperative to

${ }^{74}$ Fitzmyer, “Matthean Divorce,” 212-214; i.e., Isaeus, Isaeus, 1.36, ed. Edward Seymour Forster (Cambridge, Cambridge University Press, 1957), 69; Euripides, The Fragments, 1063.13, ed. and trans. David Kovacs, LCL (Cambridge: Harvard University Press, 1994-), 7:432; Polybius, Histories, 31.26.6, 1:63; cf. Daube, “Terms for Divorce,” 65-67.

${ }^{75}$ Catchpole, “Synpotic Divorce,” 92-127. Emphasis supplied.

${ }^{76}$ See the appendix. 
attend as to what the Markan audience may have understood upon hearing/reading the socalled "teaching on divorce." 


\section{CHAPTER 5}

\section{THE MARKAN “DIVORCE”: AN EXEGESIS}

\section{Introduction}

"Is it lawful for a man to divorce his wife?" is the introductory query posed to Jesus in the Markan (10:2) and Matthean (19:2) accounts on "divorce."1 Historically, ${ }^{2}$ generally speaking, the Christian Church has attempted to answer this question in isolation from its wider context and/or the situation in which the question was posed in the life of Jesus. Theologically, ${ }^{3}$ convictions of every persuasion concerning the “divorce" logia (Matt 5:31-32; 19:1-12; Mark 10:1-12; Luke 16:18) have been set forth with little consideration to the circumstances under which the Synoptists reported Jesus' statement on "divorce" (the Sitz im Leben of the evangelists).

The "divorce" question is often complicated when Christian interpreters of the Gospels assume that Gospel writers were on-the-scene reporters writing verbatim accounts of Jesus' teaching. Although Gospel writers were Christians who wrote for Christians, it is often overlooked that in the situation in which the stories developed, the

\footnotetext{
${ }^{1}$ See table 2-4 in chapter 4 for those Bible versions that do not translate "to divorce."

${ }^{2}$ See p.4, n. 4 .

${ }^{3}$ See p.5, n. 6 .
} 
characters in those stories were not operating under "Christian" principles, and that they were not members of a Christian church. ${ }^{4}$

Many Bible readers do not realize that the Gospels were addressed to different audiences in different cultural and/or geographical settings where the evangelists attempt to explain or to clarify basic insights of the teachings of Jesus in order to meet developing situations to those communities to whom they wrote. Many Bible students often ignore the fact that Jesus was never a "Christian," and that those who wrote about him were primarily Jews living within Jewish religious parameters and responding to Jewish concerns of their day.

It is for these and other reasons that many of the teachings of Jesus have been interpreted out of their biblical contexts. Buber's statement could not be more accurate: "We Jews know [Jesus] in a way—in the impulses and emotions of his essential Jewishness that remain inaccessible to the Gentiles subject to him." "As one who has had his own preconceived ideas overturned by his own study" and now calls it "unwise to be dogmatic as far as marriage and divorce are concerned," Wenham admits:

The biblical dicta were not uttered in a cultural vacuum; they were addressed to people who had inherited a whole system of marriage rites, laws and customs. The biblical writers all presuppose that their readers understand the background of their remarks, but today the social setting and laws and customs relating to

\footnotetext{
${ }^{4}$ Standaert, for example, states: "Its context is quite clear, Mark's passage has an edge above the other [divorce] practices [of his time] in which he seeks to inculcate a principle of Christian morality by distancing [Jesus] from the Jewish Halakah on this question." Standaert, Marc, 727; cf. Witherington, Mark, 277; Healy, Mark, 197-198.

${ }^{5}$ In Vermes, Jesus the Jew, 9; cf. Jürgen Moltmann, The Way of Jesus Christ (San Francisco: Harper SanFrancisco, 1990), 168-171; Young, Jesus, 3-7; Yancey, Jesus, 13-15.
} 
marriage are very different. It is thus difficult for western man to recapture the original force of the biblical teaching. ${ }^{6}$

The Church has traditionally relied on the Matthean account for its interpretation of the question of "divorce" (and remarriage). The unsatisfactory nature of the traditional interpretations of this question allows for one more study: What does Mark have to say on the matter? An underlying question in this study has been: Under what circumstances, geographically, historically, and culturally, did the Markan community understand the teaching of Jesus on "divorce" as recorded by the evangelist?

\section{The Geography}

"Then He arose from there and came to the region of Judea by the other side of the Jordan. And multitudes gathered to Him again, and as He was accustomed, He taught them again" (Mark 10:1). The importance of the geographical descriptions of Jesus' ministry in this particular region and his progression towards Jerusalem fits within the general framework of the Markan narrative which Schmidt called Sammelberichte (“collected reports"). ${ }^{7}$ Vander Broek has noted Jesus' progression towards Jerusalem which makes it "quite plausible to conclude that Mark is writing for a[n actual] Galilean community." 8 Schmidt identifies eleven such "reports" as Jesus moves in and around

${ }^{6}$ G. J. Wenham, "Marriage and Divorce," 6, 9.

${ }^{7}$ K. L. Schmidt, Die rahmen, 417-420. Sammelberichte is the term, according to Hultgren, that makes Schmidt the first scholar to formulate the traditional narrative framework for the Gospel of Mark which includes the narrative of "the Jesus' movement" towards Jerusalem. See Stephen Hultgren, Narrative Elements in the Double Tradition: A Study of Their Place within the Framework of the Gospel Narrative (New York: Walter De Gruyter, 2002), 310-312; cf. Betz, Pilgrimage, 3-7.

${ }^{8}$ Vander Broek, “Sitz im Leben,” 203-204. 
Gentile territory (Mark 1:14-15, 21-22, 39; 2:13; 3:7-12; 5:21; 6:6b, 12-13, 30-33, 53-56; and 10:1).

Theissen surmises that Jesus was moving in and around Galilee, mainly in the countryside, and away from heavily Jewish populations because he expected these regions to be more ready to repent than the Jewish-majority cities like Chorazim and Bethsaida. ${ }^{9}$ This geographical location in the Sitz im Leben Jesu as well as in the Sitz im Leben of the evangelist plays an important role in the development and understanding of the original question posed to Jesus since it is generally recognized that this "region across the Jordan from Judea was Perea, part of the territory ruled by Herod Antipas." The term "Galilee" plays such an important redactional role in Mark (12 times) that it cannot go unnoticed. ${ }^{11}$ Marxsen consistently demonstrated how Mark used this term in his transitions from one section to another, ${ }^{12}$ a literal geographical place where Jesus will meet his disciples after the resurrection (Mark 16:9-20).

According to Marxsen, Galilee is not only a theological term but it also reflects the Gospel's setting and the location of Mark's church, since "redaction reflects setting." ${ }^{13}$ Kelber, following Marxsen's lead, focused on the "Sea of Galilee" as the

${ }^{9}$ See Theissen, Sociology, 50-52.

${ }^{10}$ Healy, Mark, 196.

11“Galilee" has been considered to be a concoction of Mark to fit his purposes, "a symbolic term, not a geographical location." Norman Perrin, Dennis C. Duling, and Robert L. Ferm, eds., The New Testament: Proclamation and Paraenesis, Myth and History, $3^{\text {rd }}$ ed. (Fort Worth, TX: Harcourt Brace College, 1994), 150-151; cf. J. M. Van Cangh, "La Galilée dans L’Évangile de Marc: Un lieu théologique?” Revue Biblique 79 (1972): 72.

${ }^{12}$ Marxsen, Mark, 75-92; cf. R. H. Lightfoot, Locality and Doctrine, 125-128.

${ }^{13}$ Marxsen, Mark, 92. 
launching pad used by Mark to link Jesus' Galilean mission with non-Galilean cities (the Decapolis and beyond). ${ }^{14}$

When Best argues in favor of Mark's Palestinian audience based on the Gospel's numerous geographical references "unnecessarily detailed" for an audience in Rome, ${ }^{15}$ it becomes evident that the places mentioned in Mark could only make sense to Jewish and Gentile residents of Galilee and surrounding non-Palestinian towns (see Mark 5:20; 7:21) — places that would have been remote and meaningless for Gentiles in Rome. Vander Broek noted that Luke omits references to the Decapolis "presumably because it has no relevance for his mission enterprise," $" 16$ which was a Gentile audience outside of Palestine. ${ }^{17}$ For these and other reasons noted later in this chapter, I assume that the Galilean focus of Mark is a literal place in which the evangelist places the Pharisaic debate concerning "divorce" as something to be understood within that community, rather than in far-away Rome. ${ }^{18}$

\footnotetext{
${ }^{14}$ Kelber, Kingdom, 45-66, argues that the "mission-journey" section (4:35-9:50) is where the Sea of Galilee emerges as central to Gentile mission.

${ }^{15}$ Ernest Best, The Temptation and the Passion: The Markan Soteriology (New York: Cambridge University Press, 1990), 73.

${ }^{16}$ Vander Broek, "Sitz im Leben," 202.

${ }^{17}$ Chancey, in an attempt to maintain the traditional Roman setting in the Markan Sitz, is the most recent scholar to argue against Gentile influence in Galilee. See Mark A. Chancey, The Myth of a Gentile Galilee (New York: Cambridge University Press, 2002). Though not directly addressing him, Zangenberg et al. rebut Chancey point by point in support of those studies in which Gentiles play a central role in ancient Galilean communities. Jürgen Zangenberg, Harold W. Attridge, and Dale B. Martin, eds., Religion, Ethnicity and Identity in Ancient Galilee: A Region in Transition (Tübingen: Mohr Siebeck, 2007).

${ }^{18}$ For the most recent analysis of the extent of Greco-Roman cultural influences in Galilee, see Iverson, Gentiles, 20-35.
} 


\section{The Pharisees}

"And Pharisees came up and in order to test him asked, 'Is it lawful for a man to divorce his wife?"' (Mark 10:2). Over eight decades ago, in his work of rehabilitation of the Western Text $\{\mathrm{D}\}$, Turner argued in favor of the omission of $\pi \rho 0 \sigma \in \lambda \theta$ ó $\nu \tau \in \varsigma$ (oí) $\phi \alpha \rho \iota \sigma \alpha i$ ì $^{19}{ }^{19}$ Turner, among the few early scholars who rejected a Roman setting of the Markan Gospel, based his omission of "Pharisees" in the Markan logion on the argument that they frequented only the most populous places around Galilee, and that they would hardly be found in out-of-the-way places which Jesus followed on his way to Jerusalem. ${ }^{20}$ A number of supporters of a Roman setting of Mark, however, also accepted the shorter reading. $^{21}$

While the inclusion of "Pharisees" can be found in most Bible translations and assumed by most commentators of Mark, according to Metzger, the editors of the USB

${ }^{19}$ See Cuthbert H. Turner, The Study of the New Testament (Oxford: Clarendon, 1926), 60.

${ }^{20}$ Ibid., 60. Turner partially published his findings in 1920. His complete views were published in JTS 1924-1928. The omission of Pharisees in \{D $\}$ gave credence to Turner's assumption of the absence of rabbinic Judaism in Rome, plausible in the Sitz im Leben Jesu but not in the Sitz im Leben of Mark. Recent studies show that rabbinic activity was alive and well in major cities of the Jewish dispersion, especially in Rome. See for example, Menahem Stern, ed., The World History of the Jews: The Diaspora in the Hellenistic Roman World (Jerusalem: Israel Academy of Science and Humanity, 1983), 20-21, 151-152; E. R. Goodenough, Jewish Symbols in the Greco-Roman World (Princeton: Princeton University Press, 19531968), 1:14-15; Hugo Mantel, Studies in the History of the Sanhedrin (Cambridge, MA: Harvard University Press, 1965), 190-192; Moshe Beer, "Theudas of Rome and Emperor Worship in the Reign of Domitian," Zion 26 (1961): 238-239; Cecil Roth, The History of the Jews of Italy (Philadelphia: Jewish Publication Society of America, 1946), 64; Louis Finkelstein, The Pharisees, $3^{\text {rd }}$ ed. (Philadelphia: Jewish Publication Society of America, 1938), 77. There are those, however, who disclaim any rabbinic activity in Rome. See Baruch M. Bokser, "Rabbinic Authority in Rome," in New Perspectives in Ancient Judaism: Religion, Literature, and Society in Ancient Israel, ed. Jacob Neusner (Atlanta: Scholars, 1990), 1:117-130; A. T. Krabel, "Social Systems of Six Diaspora Synagogues," in Ancient Synagogues: The State of Research, ed. Joseph Gutmann (Chico, CA: Scholars, 1981), 79-91; Shaye J. D. Cohen, "Epigraphical Rabbis," JQR 72 (1981): 1-17. For more manuscript evidence in Mark, see James Keith Elliot, The Language and Style of the Gospel of Mark, Supplement to Novum Testamentum 71 (Leiden: Brill, 1993), 65-67.

${ }^{21}$ Taylor, St. Mark, 416; Nineham, Mark, 259; implied by Lohmeyer, Markus, 199; with some modifications by Anderson, Mark, 240; Cranfield, St. Mark, 318; as well as by the NEB translators. 
Greek text voted 3-2 to retain "Pharisees," Metzger himself casting a dissenting vote. ${ }^{22}$

Bultmann, who also favored the omission of "Pharisees" in $\{\mathrm{D}\}$, writes:

There is an active tendency seeking always to present the opponents of Jesus as Scribes and Pharisees. Even their appearance in Mark 2:16ff is inappropriate; they are always present when the editor needs them (as in Mark 2:6) [sic] as typical participants in debate. In Mark 2:18 they are secondary to John's disciples, and in Mark 10:2 they are possibly rightly omitted. ${ }^{23}$

A contextual analysis of the Gospel, nevertheless, makes it difficult to miss the "Pharisee" motif. They are mentioned ten times (2:16, 2:18 twice, 2:24; 3:6; 7:1, 3, 5; $8: 11,15)$ in a confrontational stance prior to their face-off with Jesus in chap. 10. In the section immediately preceded by the "divorce" logion, Jesus has crossed the lake and gone to "an out of the way place" called Dalmanutha (or Magadan). He is once again confronted by Pharisees who ask for a sign (Mark 8:10-12). When Jesus and his disciples embark to cross the lake towards the north, to Bethsaida, he warns the disciples to "beware of the leaven of the Pharisees and that of Herod" (8:15).

Jeremias considers that the inclusion of "Pharisees" in the Sitz im Leben Jesu is more likely than not. If Pharisees is omitted from the narrative, Jeremias asks, "What interest would the common Jewish people have in theological debates?"24 True. And by the same token, what interest would Gentiles in Rome have in wanting to debate things pertaining to Jewish customs and/or theology in far-away Palestine?

\footnotetext{
${ }^{22}$ See Metzger, Commentary, 104. Metzger, in an appendix of his 1994 edition, argued for the omission.

${ }^{23}$ Bultmann, History, 52-53, emphasis is his. See also, Robert Banks, Jesus and the Law in the Synoptic Tradition (New York: Cambridge University Press, 1975), 146.

${ }^{24}$ Joachim Jeremias, New Testament Theology (New York: Scribner, 1971), 1:108.
} 
Early in the debate Dibelius argued, "I do not think that the members of these communities carried theological discussions with their adversaries, and so I do not think that the polemical discourses of Jesus with his opponents recorded in the gospels are imaginary scenes. ${ }^{25}$ Along the same vein, Philipose chimed in: "Depriving chapter 10 of the role of the Pharisees in approaching Jesus with the tricky question of divorce would result in a long gap in Mark's development of the ... motif of conflict between Jesus and the Jewish leaders culminating in the crucifixion., ${ }^{26}$ To which Westerholm adds, "Mark's inclusion of 'Pharisees' does not distort the Markan account since it plays well with the Pharisaic-Herodian plot and Jesus' 'messianic secret' motif."27

\section{The "Test" Question}

"And Pharisees came and in order to test him asked, 'Is it lawful for a man to divorce his wife?" $\mathrm{E} \xi \epsilon \tau \iota \nu^{28}$ is found a total of 28 times in the Greek NT; 19 of which are found in the Synoptic Gospels: six in Mark $(2: 24,26 ; 3: 4 ; 6: 18 ; 10: 2 ; 12: 14)$, eight in Matthew $(12: 2,10,12 ; 14: 4 ; 19: 3 ; 20: 15 ; 22: 17 ; 27: 6)$, and five times in Luke $(6: 2,4,9$; $14: 3 ; 20: 22)$.

To the question, "Is it lawful for a man to divorce his wife?" ( $\epsilon \grave{\iota}$ " $\xi \xi \sigma \tau \iota \nu \alpha \dot{\alpha} \nu \delta \rho \grave{\imath}$

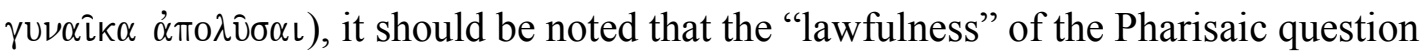

30.

${ }^{25}$ Martin Dibelius, Gospel Criticism and Christology (London: Ivor Hicholson \& Watson, 1935),

${ }^{26}$ Jonathan Philipose, "Western Non-Interpolations and Related Phenomena in the Gospels" (Ph.D. diss., St. Andrews University, 1961), 296; cf. Ellingworth, "Text and Context," 63-66. 1978), 121.

${ }^{27}$ Stephen Westerholm, Jesus and Scribal Authority (Lund, Sweden: LiberLäromedel/Gleerup,

${ }^{28}$ While " $\xi \in \sigma \tau \iota \nu$ is translated "is it lawful?" by most versions, BDAG contains, "Is it proper?" "Is it permitted?" "Is it possible?" BDAG, s.v. "E $\xi \in \tau \iota \nu . "$ 
does not envision a generic "man." There is no indication of any kind of political correctness in this Pharisaic encounter with Jesus as to ask: "Is it lawful for a married person to divorce his/her spouse?"29 There is no historical evidence where a judge, court, or any third party interference (such as in-laws generally implied in wedding vows) would be in view here. There is no hint that Jesus was violating any Pharisaic doctrine." ${ }^{30}$ There is absolutely no indication that "man" is being used in reference to a male lawyer suing for divorce on behalf of his client. Any such considerations would be anachronistic, since a Jewish male could divorce his wife by simply saying to her, "You are free to marry whomever you wish. ${ }^{31}$ Because the androcentricity of the question is not only

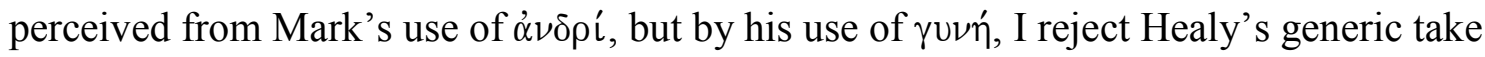

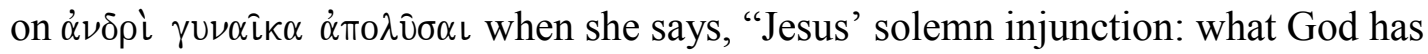
joined together, no human being must separate ... [for] no human being is authorized to dissolve that bond once it has been made., ${ }^{32}$

According to Mark (and Matthew), the question, "Is it lawful for a man to divorce his wife?" was presented "in order to test him." What would this "test" involve? What was lurking behind the Pharisaic question that it would become a "test"? Were they really interested in finding out whether Jesus found it "[un]lawful for a [Jewish] man to divorce

\footnotetext{
${ }^{29}$ I question whether Davidson's use of "spouse" (see Davidson, Flame, 654) is the correct term given not only how Judaism practiced divorce (the male-centric practices as detailed in the Mishnah and the Talmudic tractates Gittin), but the syntax within the Gospels' narratives clearly contains an androcentric focus. In Jewish understanding there is no porneia committed by a married Jewish man who takes a second free woman (single, widowed or divorced) as a wife.

${ }^{30}$ Boring, Mark, 287.

${ }^{31}$ See m., Git. 9.3.

${ }^{32}$ Healy, Mark, 197.
} 
his wife" ["for anything" in the Matthean Sitz]? And if Gentiles are the main concern in Mark, did Jesus believe it was "[un]lawful for a [Gentile] man to divorce his wife"?

That this question concerns divorce is "difficult to imagine" $" 33$ in a cultural milieu where divorce is the accepted practice makes it "improbable to characterize as the pertinent question within the narrative," is Standaert's on target observation. ${ }^{34}$

The question has not gone unaware to a great number of NT scholars. Many have set the Matthean account in the context of the Hillel-Shammai debate over the 'erwat dabar of Deut 24:1. ${ }^{35}$ Others contend that the "test" question concerned a debate between Judaism and the Essene community. Mueller, for example, insists that "the Pharisees could very well have asked Jesus whether he sided with the majority of Judaism which apparently allowed divorce, or with the Essenes, who clearly prohibited the practice"; 36 while Fitzmyer espouses the notion that the question was "an ensnarement in either polygamy or divorce. ${ }^{, 37}$ Although Healy acknowledges "Jesus had already given a teaching on the matter that conflicted with the concession in the law," the Pharisees, in an

${ }^{33}$ Joseph Ernst, Das Evangelium Nach Markus (Regensburg: Friedrich Pustet, 1981), 84.

${ }^{34}$ Standaert, Marc, 722; cf. Boring, Mark, 286; Theodore Laetch, "Divorce and Malicious Desertion," CTM 4 (1933): 128.

\footnotetext{
${ }^{35}$ Gane asserts that "in Matt 5:32, Jesus' Greek phraseology follows the syntax of the House of Shammai formulation [of the] logou porneias." Roy Gane, "Principles," 48; cf. Louis M. Epstein, The Jewish Marriage Contract: A Study in the Status of the Woman in Jewish Law (New York: Arno, 1973), 196-197. Daube calls Matthew "a rabbinic Gospel." Rabbinic Judaism, 60. See also Bartling, "Sexuality," 365-366; Derrett, Law, 377-381; Lehmann, "Divorce," 266-268.

${ }^{36}$ James R. Mueller, "The Temple Scroll and the Gospel Divorce Texts," RevQ 38 (1980): 255. It seems highly improbable that the "test" question involved the Qumran community's position on divorce. The practices of this secluded sect do not appear to have gone "mainstream." Besides, whatever Jesus might answer, it does not seem that it would produce any kind of entrapment. Instone-Brewer, "Intertestamental Period: Increasing Rights for Women," Divorce, 61-72, asserts that the Qumran community prohibited not divorce, but polygamy; cf. Dungan, Sayings, 11-12; Abel Isaksson, Marriage and Ministry in the New Temple (Lund: C. W. K Gleerup, 1965), 57-63; Chaim Rabin, trans., The Zadokite Documents (Oxford: Clarendon, 1954), 6-9.
} 
apparent hidden agenda of their own, probe him publicly again (see Mark 3:6; 7:5; 8:11; 12:13) "in order to expose what they considered his unorthodox views." ${ }^{38}$ Boring correctly asserts that "they [the Pharisees] are not seeking his opinion on a disputed point, but already know how he will respond and wish to use it against him to discredit him." ${ }^{39}$ Collins' view was that Jesus went against Moses. ${ }^{40}$ Moloney's is that this "test" question was "based upon a previous knowledge of Jesus' absolute prohibition of divorce, ${ }^{, 41}$ which also appears to be the implication proposed by Davidson when he states that "the husband's putting away his wife [for reasons other than porneia on her part] has in effect caused her to defile herself in a second marriage in a similar way as if she were committing adultery." ${ }^{42}$

To propositions such as these Neufeld reacts: "Moses, in their [Pharisaic] opinion gave freedom [to divorce]. ... Why should they ask Jesus? They found in Scripture (rightly or wrongly) no reason to believe their subsequent marriages were illegitimate, and neither did their teachers.. ${ }^{, 3}$ Friedman, a Jewish rabbi, states: "The unilateral aspect of Jewish divorce law is one of its most distinctive features.... The basic principle is that

${ }^{37}$ Fitzmyer, "Matthean Divorce," 216.

${ }^{38}$ Healy, Mark, 196.

${ }^{39}$ Boring, Mark, 286.

${ }^{40}$ R. F. Collins, Divorce, 94.

${ }^{41}$ Moloney, Mark, 194; cf. Antonio Vargas-Machuca, "Divorcio e Indisolubilidad del Matrimonio en la Sagrada Escritura," EstBib 39 (1981): 34.

${ }^{42}$ Davidson, Flame, 656. Davidson's quotation of Charles shows his belief that in Jesus' teaching in the Gospels there is no divorce except for porneia. Charles states: "What is implicit in Mark is made explicit in Matthew. Both gospels therefore teach that marriage is indissoluble for all offences short of adultery." R. H. Charles, Teaching of the New Testament, 21; quoted in Davidson, Flame, 655n89. This view is totally foreign even to the most conservative of Jewish thinking.

${ }^{43}$ Neufeld, "Marriage and Divorce," 32. 
the termination of marriage by divorce can be affected only when the husband, of his free will, issues a bill of divorce to his wife," hardly contested in first-century Judaism." 45 According to Stock, "If a man wanted to get rid of his wife, he wouldn't simply send her away. He must write her a letter of divorce. . . He must document that she is no longer his wife." 46

Besides, how would the Hillel-Shammai debates play out in the Markan account where Gentiles appear to be Mark's principal audience? Harrington writes, “In Mark’s formulation, the question is not related to the Shammai-Hillel controversy, it concerns simply divorce as such and originated ... within the Marcan material."47

Schweizer finds that "none of Jesus' contemporaries would have asked him [this] question." 48 If the question was on the practice of divorce, it would naturally draw away from a Jewish practice, a hint that something else lurked behind the question, for as Neufeld aptly points out, "Unless Mark totally modified the original encounter, the question posed to Jesus in his life-setting reflects something other than divorce. . . The

\footnotetext{
${ }^{44}$ Mordechai A. Friedman, Jewish Marriage in Palestine: A Cairo Geniza Study, 2 vols. (New York: Jewish Theological Society of America, 1980), 1:312. 128.

${ }^{45}$ Boring, Mark, 286; cf. Theodore Laetch, “Divorce and Malicious Desertion,” CTM 4 (1933):

${ }^{46}$ K. Stock, Marco, 195.

${ }^{47}$ Wilfred Harrington, “Jesus’ Attitude towards Divorce,” ITQ 27 (1970): 200.

${ }^{48}$ Schweizer, Good News, 202; cf. Nineham, St. Mark, 260; or as Dungan recognizes that “Mark's version of the question is inconceivable in a Palestinian milieu." Dungan, The Sayings of Jesus, 111. To Dungan, however, this question is "inconceivable" from the standpoint that the setting in Mark 10:2-12 is a Hellenistic-non-Palestinian. Dungan questions the methodology of any commentator who implies that there are "ulterior or sinister motives on the part of the Pharisees for putting such an obviously phony question." Sayings, 103.
} 
evangelist states that the intention was to trap Jesus."49

In terms of the Jewish historical interpretation of Moses, the main question is: If Judaism did not prohibit remarriage subsequent to a divorce during the lifetime of the woman who has been divorced, ${ }^{50}$ how would this question be problematic for new Christians in a pagan society where the laws of marriage and divorce were non-existent? Where they did exist, such laws were reserved for the upper classes. ${ }^{51}$

From what is known of Jewish-Palestinian life, was Jesus saying that remarriage after divorce places the person in perpetual adultery as a considerable number of Christians have historically stated? Is this what the audience in the Sitz im Leben Jesu understood? Is this what Mark's audience understood? No wonder Klausner calls the traditional Christian interpretation of Jewish divorce practices "an exaggerated Judaism [from] the most Jewish of Jews" "52 since "remarriage after divorce was enshrined in. . . Jewish law. ... the sole purpose of the Jewish divorce certificate." ${ }^{, 53}$

\footnotetext{
${ }^{49}$ Neufeld, "Marriage after Divorce," 31. Emphasis supplied.

${ }^{50}$ Polygamy, though frowned upon, was still permissible among Jews in the first century, see $m$.
} Ket 10:1-6; cf. $m$. Ker 3:7. Josephus states, "[It was] an ancestral custom of ours to have several wives at the same time." Antiquities 17.1.2. Emphasis supplied. The levirate law, by its own implication, encouraged the taking of a second wife, albeit, a brother's wife, but a wife, nevertheless. See $m$. Yeb 4:11. When the question about this practice was brought up to Jesus in Luke 20:27-37, there is no indication that he disapproved of it. The only prohibited marriages appear to be those with family members. See $m$. Qidd 2:78.

${ }^{51}$ Tacitus writes that with the coming of the empire, marriage came into disuse, except for a few political marriages of convenience among the rich. Tacitus, Annals, 4.16. Seneca writes that legal marriages were reserved for Roman citizens. Ben. 4.35. In a free marriage, which was the main form of marriage of the Roman populace, divorce ended by mutual consent or by repudium (meaning, abandonment or expulsion from the man's house); see Adolf Berger and Barry Nicholas, "Marriage, Law of," The Oxford Classical Dictionary, 3rd ed., ed. Simon Hornblower and Antony Spawforth (New York: Oxford University Press, 2003), 649-650. For a complete analysis, see chapter 3.

\footnotetext{
${ }^{52}$ Klausner, Jesus of Nazareth, 374.

${ }^{53}$ Instone-Brewer, “Divorce Papyri 2,” 237.
} 
That the ${ }^{\prime} \xi \in \sigma \tau \iota \nu$ question is embedded in the Markan narrative, as one in which traps are constantly set before Jesus, may be seen in the following: Except for Matt 14:4 (par to Mark 6:18);20:15, and 27:6, the remaining fifteen times that ${ }^{\prime} \xi \xi \sigma \tau \iota \nu$ appears in the Gospels belong to controversial encounters between Jesus and Pharisees, PhariseesScribes, or Pharisees-Herodians where the "lawfulness" of something or other is always an attempt to entrap Jesus: There are Sabbath controversies (Matt 12:2, 10, 12; Mark 2:24, 26; 3:4; Luke 6:2, 4, 9; 14:3), the question of "divorce" (Matt 19:3; Mark 10:2), and the question of paying taxes to Caesar (Matt 22:17; Mark 12:14; Luke 20:22). Each of these confrontations was successfully rebutted by Jesus, quieting his Pharisaic opponents.

This "lawfulness" issue is not a subtle redactional element of the evangelist; Mark places the "testing" as the culmination of the Pharisaic encounter at a critical juncture of Jesus' ministry. Both Mark (6:18) and Matthew (14:4) contain the Baptist's badgering of Antipas for his illicit relationship with his brother's wife. Now they need to confront Jesus as to whether he feels the same way about that relationship as John did. The Pharisees appear to want to place John's words in Jesus' lips. If they are able to do this and prove that Jesus also condemns Antipas, they can perhaps be able to bring to him the same fate as that of the Baptizer. Stein clarifies:

If this is true, the Pharisees" testing Jesus "across the Jordan" may have involved less a desire to learn Jesus' theological position on the issue of divorce and remarriage than an attempt to ensnare him in a statement that would have angered Herod. This may be why the question is worded as it is. If this were simply an inhouse question, one might expect a question concerning the just causes for divorce. $^{54}$

\footnotetext{
${ }^{54}$ Stein, Mark, 455; cf. Harold W. Hoehner, Herod Antipas (Grand Rapids, MI: Zondervan, 1980), 199-202; Joaquim Jeremias, Teología del Nuevo Testamento (Salamanca: Sígueme, 1980), 262; Lane, Mark, 355; Joseph B. Tyson, "Jesus and Herod Antipas," JBL 79 (1960): 230-246; Josephus Josephus
} 
Stein is one in a long string of scholars who have placed the "test" question in the context of the house of Herod. Stock writes: "They wished to get Jesus into trouble with the king ... provoking a conflict for which his own marriage problem had in fact put John the Baptist in prison which eventually had him decapitated. ${ }^{.55}$ Herron considers that "Mark's narrative could not have gone unnoticed by his first century readers." He clarifies: "Mark's important literary clues are the roles assumed by the Pharisees and the Herodians in the gospel. The knowledge that Jesus was ministering in the hostile region of Herod Antipas, and notice of the hostile intentions of the questioners [are] revealed in the word 'tempting.","56

It is difficult not to notice the verbal agreements between Mark 6:18 and Mark

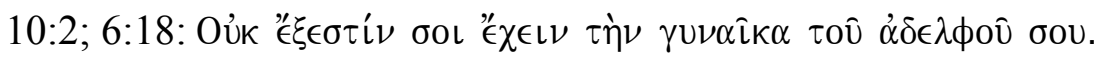

It is not lawful for you to have your brother's wife.

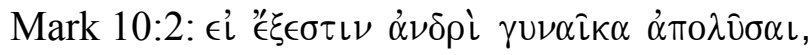

Is it lawful for a man to divorce his wife?

Mark's report of the Baptist's early arrest by Antipas (1:14), Mark's report of Antipas's fear of John and his belief that he had been raised from the dead and now walks around in the person of Jesus $(6: 14,20)$, the structural connectors ${ }^{57}$ between Mark 10:2 and 10:11-12 in which the actions of Antipas and Herodias appear to be implied, all seem to point to the question of ${ }^{\prime} \xi \epsilon \sigma \tau \iota \nu$ of Mark 10:2. The implication seems inevitable: The

(trans. Thackeray, 9:147-149); Robert H. Stein, "Is It Lawful for a Man," JETS 22 (June 1979): 116-119; Josephus Antiquities 18.5.1, 18.7.2.

\footnotetext{
${ }^{55}$ K. Stock, Marco, 195.

${ }^{56}$ Herron, “Mark’s Jesus,” 276-277.

${ }^{57}$ See the structural analysis in the previous chapter.
} 
${ }^{\prime} \xi \xi \in \tau \iota \nu$ question posed by the Pharisees to Jesus concerning the specificity of a particular man to "divorce" his wife (10:2, it is in the singular), and the "“ $k \xi \in \sigma \tau \iota v$ " that Mark places in the Baptizer's lips of "having your brother's wife" (6:18), do not appear to be haphazard coincidences, rather, redactionally intended by the evangelist. Here is a man who has taken as wife a woman still considered married under Jewish law ${ }^{58}$ and they wanted to "test" Jesus on the matter.

This "test" question posed to Jesus, Baltsenweiler suggests, is a "Sachfrage."

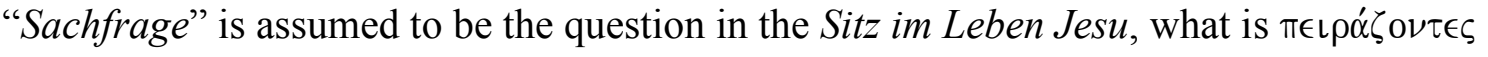
("in order to entrap him") doing as a punch line? Catchpole has shown that $\pi \epsilon \iota \rho \alpha ́ \zeta \omega-$ related passages are generally connected to events in which Jesus is cornered or put on

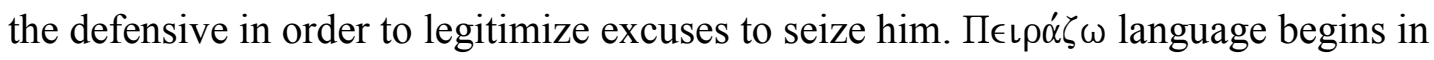
Mark where the present passive participle is used to denote a constant besieging, whether by Satan (1:13) or the Pharisees here in Mark 10:2 over the legality of "divorce."60

This constant besieging also can be found in 8:11 as Jesus is again "tested" ( $\pi \epsilon \iota \rho \alpha ́ \zeta o \nu \tau \epsilon \varsigma)$ by the Pharisees where they ask for a sign from heaven; whereas in 12:1315 Jesus recognizes the "temptation" (read, "entrapment") in $\pi \epsilon\llcorner\alpha \alpha ́ \zeta \epsilon \epsilon \in$ where the Pharisees, urged by the Herodians, badger him on the question of the legality of paying or not paying taxes to Caesar. Jesus' magnificent answer silences his "tempters" as he did in $10: 2-12$.

${ }^{58}$ See Josephus Antiquities 18.5.4.

${ }^{59}$ A factual question versus "Fangfrage," or trick question. Baltensweiler, Die Ehe, 84; Catchpole, "Synoptic Divorce," 94.

${ }^{60}$ See Catchpole, “Synoptic Divorce,” 94. 
That the Pharisees and/or their Scribes, and the Herodians have been stalking Jesus from the beginning of his ministry can hardly be missed in Mark. The Scribes of the Pharisees charged him with blasphemy for forgiving sins (2:6-7); again they plot in their hearts for eating with sinners (2:16-17). The Pharisees murmur against him for not fasting (2:18) and then follow him closely on a Sabbath and catch him "harvesting" wheat (2:24). When Jesus openly heals a man with a withered hand on the Sabbath, the Pharisees and Herodians are there again plotting to ensnare him (3:1-6). In 3:22 Jesus is accused of being a servant of Beelzebub; in 7:1 the Pharisees and some of their Scribes "had come from Jerusalem" where again they are found "spying" on Jesus' disciples and discover them eating without the ceremonial washing of hands (7:2). They then proceed to accuse Jesus of not observing the traditions of the fathers (7:3).

Jesus notices their stalking and warns the disciples: "Take heed, beware of the leaven of the Pharisees, and of the leaven of Herod" $(8: 15) .{ }^{61}$ Why Herod? In Mark 8 Jesus flees from Herodian territory. The counterpart to this story is found in Luke 11:53 to 13:31. This is the Lukan account: "As he went away from there, the scribes and the Pharisees began to press him hard, and to provoke him to speak of many things, lying in wait for him (emphasis supplied), to catch at something he might say" (11:53-54). Luke 12:1 contains the parallel statement to Mark 8:15, "Beware of the leaven of the Pharisees." Here Herod is not mentioned, but it does not mean he is out of mind. Luke makes an interesting statement not found in Mark, "At that very hour some Pharisees came, and said to him, 'Get away from here, for Herod wants to kill you'” (13:31).

\footnotetext{
${ }^{61}$ In Caesarean MSS Mark 8:15 reads, "beware of the leaven of the Pharisees and of the Herodians, $" \mathrm{p},{ }^{45} \mathrm{~W}, \mathrm{f},{ }^{1} \mathrm{f},{ }^{13}$ et al.
} 
It is interesting to note that Luke mentions Antipas at the precise moment Jesus is moving away from his territory. This is the complete sentence in the Lukan account, "Beware of the leaven of the Pharisees, which is hypocrisy" (12:1, emphasis supplied), a hypocrisy apparently camouflaged under their questions of entrapment. Pharisees and/or Scribes appear nine more times in Luke attempting to entrap Jesus $(11: 18,27 ; 12: 28,38$, $40 ; 14: 1,43,53 ; 15: 1,31) .{ }^{62}$ This "hypocrisy" is seen again in Mark 12:15 when Pharisees and Herodians make one last attempt to pin Jesus against the proverbial wall as they pose the question on the "legality" of paying taxes to Caesar: "knowing their hypocrisy, he said to them, "Why put me to the test? (Tí $\mu \epsilon \pi \epsilon \iota \alpha \dot{\zeta} \zeta \in \tau \epsilon)$."”

Markan internal evidence shows Baltsenweiler's "Sachfrage" not to be the case. The "test" element in 10:2 shows treacherous intentionality ("Fangfrage"). Stein states that "for Jesus, as well as the Pharisees, Moses was the author of the Law/Pentateuch."63 “There was no apparent debate among first century Jews [on] the right to marry after divorce," says Neufeld. ${ }^{64}$ Sanders asserts that "there was no substantive point of disagreement between Jesus and the Pharisees" ${ }^{65}$ on the question of what Moses had written concerning the proper procedure in which a man writes her a certificate of divorce, puts it in her hand, and sends her out of his house; she then leaves his house.

\footnotetext{
${ }^{62}$ For more on the role of the Jewish authorities and their plot to ensnare Jesus, see Robinson, Problem of History, 94-96.

${ }^{63}$ Stein, Mark, 455.

${ }^{64}$ Neufeld, "Marriage after Divorce," 26.

${ }^{65}$ Ed Parish Sanders, Jesus and Judaism (Philadelphia: Fortress, 1985), 210. See also, Sanders, "Jesus and the Sinners," 5-36; and Ed Parish Sanders and Margaret Davies, Studying the Synoptic Gospels (Philadelphia: Trinity, 1989), 149, where they propose that the divorce test was just one more in "the mounting opposition [against Jesus by the Pharisees]."
} 
If the question concerning divorce is not what the Pharisees have in mind, then something other than divorce looms behind the question, which traditional interpreters have missed. Traditional interpreters of Mark appear to place Jesus and the Pharisees in opposite sides as to what Moses had written; but the question is what Mark says it is: A test/trap (10:2). Stein's take seems on target as he considers that the Pharisee-Herodian motif in Mark can be seen in each controversial encounter, which are nothing but traps to catch Jesus and to take him to the same fate as that of John the Baptist.

Stein aptly states: "[All this] indicates that this was not a sincere theological question but an attempt to entrap him ... [and that] behind the question lay a dangerous political issue, ${ }^{, 66}$ about which Mark has hinted throughout his Gospel, involving the house of Herod. Gibson, in his analyses of various "temptations" which Jesus encountered throughout his ministry, also posits that $\pi \in \iota \rho \alpha ́ \zeta o \nu \tau \epsilon \varsigma$ is the effort on the part of the Pharisees to have Jesus make a public statement against Herod, ${ }^{67}$ as does Garrett. ${ }^{68}$ It has been pointed out ${ }^{69}$ that conflict, be it with demons, nature, or persons, is at the heart of most of the stories in Mark. The difficult conflicts, however, lie not with demons, nor with nature, since Jesus has authority over them. The difficult conflicts arise with people; so it is not surprising to find a culminating conflict in Mark 10:2-12, a conflict that had been escalating against Jesus from the Pharisee-Herodian.

\footnotetext{
${ }^{66}$ Stein, Mark, 455.

${ }^{67}$ See Jeffrey B. Gibson, “Jesus' Divorce Question Temptation according to Mark," in The Temptations of Jesus in Early Christianity (London: T \& T Clark, 2004), 268-287.

${ }^{68}$ See Susan R. Garrett, “Testing by Jesus' Enemies,” in The Temptations of Jesus in Mark's Gospel (Grand Rapids, MI: Eerdmans, 1998), 61-64.

${ }^{69}$ See David Rhoads and Donald Michie, Mark as Story: An Introduction to the Narrative of the Gospel (Philadelphia: Fortress, 1982), 733-736; cf. Cook, Mark's Treatment, 46-55.
} 
Parker put together an array of internal evidence from the Synoptics and John, verifying the connections between Jesus, John the Baptist, and the Herodian-Pharisaic plot against him through direct or implied actions. ${ }^{70} \mathrm{~A}$ few of those encounters are noted here: John moves along the Jordan valley, occasionally further west, but most of his work is in Perea, Antipas's territory (Luke 3:3; John 1:28; 3:23).

Josephus, as well as the Gospel writers, note that John drew huge crowds, which caught Antipas's attention (Antiquities 18.5.2; Matt 3:5-17; 11:7; Mark 1:5; Luke 3:7; 7:24; John 1:19-28; 3:23-36; 10:41). John castigated Antipas for adultery and other sins (Mark 6:17-29; Matt 14:3-12; Luke 3:19). Mark (6:20) says that Antipas feared John and that he even enjoyed listening to him speak, and that at times tried to protect him. Matthew (14:5) states that Antipas wanted to kill him, but feared the people around him. Eventually, Antipas jailed John in the Machaerus fortress (Antiquities 15.5.2). Upon John's arrest, Jesus transferred his ministry to Antipas's territory where he too confronted him. The Baptist, as prophet and close relative, and John's disciples were important to Jesus (Luke 7:29; 11:1; Matt 17:13; John 10:41-42).

Like John, Jesus also attracted large crowds and resorted to desert preaching which alarmed Antipas (Mark 1:28, 37, 45; 2:2, 13). To make matters worse, at least two from Antipas's court joined the "Jesus movement": Manaen, who had grown up with Antipas, and Joanna, Chuza's wife, Herod's steward (Luke 8:3; Acts 13:1; cf. Antiquities, 15.10.5). After John's execution, Antipas asked to see Jesus, believing that it was John

\footnotetext{
${ }^{70}$ See Pierson Parker, "Jesus, John the Baptist, and the Herods," Perspectives in Religious Studies 8 (Spring 1981): 4-11. For a full treatment of the level of Jesus' opposition, see Robert Mullholland, "The Markan Opponents of Jesus" (Ph.D. diss., Harvard University, 1977), 131-134.
} 
who had risen from the dead (Mark 6:14; cf. Matt 14:1 and Luke 9:7, 9).

Evidently, Jesus knew his intentions. His response? "Go and tell that fox, 'Behold, I cast out demons and perform cures today and tomorrow, and the third day I finish my course"" (Luke 13:32). ${ }^{71}$ It is around this time that Jesus crosses the river to Antipas's jurisdiction (Mark 10:1; Luke 9:10), and it is at this juncture that the question of "divorce" comes as a "test."

\section{The Role of Moses}

“He answered them, 'What did Moses command you?' They said, 'Moses allowed a man to write a certificate of divorce, and to put her away.' But Jesus said to them, 'For your hardness of heart he wrote you this commandment."' (Mark 10:3-5). It should be clarified from the start that where some may see Jesus being pitted to respond with Torah against Torah, ${ }^{72}$ the general consensus is that Jesus is in no way disputing the authority of the Mosaic Law. ${ }^{73}$

Boring, for one, considers that "the argument here is not merely pitting one Scripture against another. ... The later law, though itself from God, is only a concession, and does not correspond to the original will of God given in creation ... . [that in the end] there is no contrast between God and Moses.",74

Whereas ${ }^{\prime}{ }^{\prime} \xi \in \sigma \tau \iota \nu$ for divorce proper was envisioned in the law of Moses, and since

\footnotetext{
${ }^{71}$ Antipas is last seen in Jerusalem during Jesus' trial, conspiring with the Sanhedrin to have Jesus killed, finally getting his wish (see Acts 4:27).

${ }^{72}$ See Moloney, Mark, 194.

${ }^{73}$ See Witherington, Mark, 276, cf. Stein, Mark, 455.

${ }^{74}$ Boring, Mark, 287.
} 
this "lawfulness" has been raised in relation to $\dot{\alpha} \pi \mathrm{o} \lambda \hat{\text { }} \alpha \mathrm{L}$, Jesus' counter-question attempts to place his inquirers in their biblical context: "What did Moses command you?" (10:3). Jesus' counter-question elicits other questions: Were Jesus and the Pharisees in opposite bands regarding the legal divorce procedure as expressed in the Torah, as some have suggested $?^{75}$ Did Jesus establish a new interpretation of Deut 24:1-4 or that "Jesus, the master exegete, restores the true meaning of the text" ${ }^{76}$ as Davidson posits.

Because in Matthew's account the Pharisees introduce Moses into the debate on the question of "lawfulness" (Matt 19:7), Catchpole considers that "what Moses permits, the Jesus of Mark and the Jesus of Q forbid." ${ }^{, 77}$ If this is so, how would such a concept play in the Markan community where it is Jesus who introduces Moses and using commandment language? Whereas the Matthean account reverses the order, placing "permission" in the lips of Jesus and "commandment" in the lips of the Pharisees, Schweizer's proposal makes perfect sense when he notes that the questioners in Matthew place "Jesus in a position where he has to criticize the biblical quotation, which I find it to be quite the opposite, since here in Mark it was Jesus who brought up the Mosaic

\footnotetext{
${ }^{75}$ See Healy, Mark, 196-197; Davidson, Flame, 654-657; Richard C. H. Lenski, The Interpretation of St. Matthew's Gospel (Minneapolis: Augsburg, 1961), 711; Cranfield, St. Mark, 319; Ned B.

Stonehouse, The Witness of Matthew and Mark to Christ (Philadelphia: The Presbyterian Guardian, 1944), 204.

${ }^{76}$ Davidson, Flame, 656. According to Davidson, Jesus' restoration "of the true meaning of the text" is based his analysis of Deut 24:4 in which "her first husband, who sent her away, is not permitted to take her again to be his wife after she has been defiled," which Davidson translates, "she has been made/caused to defile herself." This "self-defilement" is seen by Davidson to mean that "sexual activity of the divorced woman with the second husband is tantamount to adultery" which in essence, God (or Moses) never really sanctioned divorce, thus making Deut 24:1-4 totally obsolete. See Davidson, Flame, 395-396.

${ }^{77}$ Catchpole, "Synoptic Divorce," 112.
} 
command. This works well with the Markan intention within Mark's redactional thrust." 78

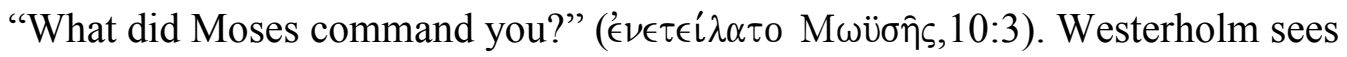
this as Jesus" "halakic" understanding of Moses, but that the Pharisees want to take Deut

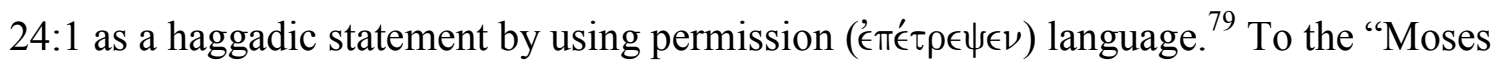
allowed" response of the Pharisees, Weinfeld argues that "there may be indications that the intentions of Deuteronomy were didactic rather than legally prescriptive. ${ }^{80}$ Alt considers that although Deut 24:1-4 may be termed as "apodictic law" (versus casuistic) in terms of rabbinic understanding/interpretation, nevertheless, this kind of law "was not for the courts" ${ }^{\prime 81}$ in the legal sense. ${ }^{82}$ This position is echoed by Jackson who states: "The legal documents of the Torah in general, though reflecting legal practice, were not intended as law binding in the courts." ${ }^{, 83}$ To Encyclopedia Judaica, however, the Pentateuch was seen as the "constitution," the "supreme legislation" of Jewish law ${ }^{84}$ and that in the case of Deut 24:1-4, in particular, it was clearly understood as legally binding,

${ }^{78}$ Schweizer, Good News, 203.

${ }^{79}$ See Westerholm, Scribal Authority, 121-122.

${ }^{80}$ Moshe Weinfeld, Deuteronomy and the Deuteronomic School (Oxford: Clarendon, 1972), $167-$ 169; cf. Davidson, Flame, 389-390, who argues that Deut 24:1-3 is a casuistic law, rather than apodictic, and that the only legislative part is in v. 4.

${ }^{81}$ Albrecht Alt, "The Origins of Israelite Law," in Essays in Old Testament History and Religion, trans. R. A. Wilson (Oxford: Basil Blackwell, 1966), 103. See n. 80 above.

$82 \ldots$ in which a Jewish court needed to intervene, that is, which it did, but only in rare instances. See $m$. Ned 11:12; cf. m. Ketub 7:10. The rabbis considered that when three witnesses were involved in a divorce procedure, the divorcing husband "turned them into a court of law." m. Git 6.7.

${ }^{83}$ Bernard S. Jackson, Essays in Jewish and Comparative Legal History (Leiden: Brill, 1975), 27.

${ }^{84}$ See "Takkanot," Encyclopedia Judaica, trans. Cecil Roth (New York: Macmillan, 1971-1972), 15:712-728; cf. Ed Parish Sanders, Paul and Palestinian Judaism (Philadelphia: Fortress, 1977), 76-79. 
rather than didactic. Westerholm has pointed out three areas in which halakah was established based on rabbinic understanding of Deuteronomy:

1. Words and letters were crucial for establishing halakah as the debates between Hillel and Shammai show (see m. Git 9.10; b. Sanh 51b).

2. Changing conditions required reassessments of old interpretations of what they considered biblical "statutory law," which made it impossible for the Pharisees "to rule according to the spirit" of the law over the letter which would sabotage their own legal system. ${ }^{85}$

3. The law had to be practical and at the same time "make a fence around it to guarantee that the letter was not infringed [upon] (see m. Abot $1.1 ; m$. Ber 1.1$).{ }^{86}$

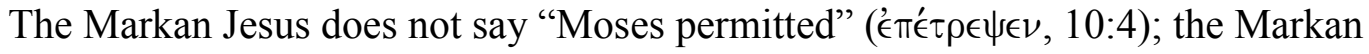
Jesus says "Moses commanded," twice $(10: 3,5)$. Some have noted that Moses never gave any command to divorce. ${ }^{87}$ Schweizer, however, proposes that by using commandment

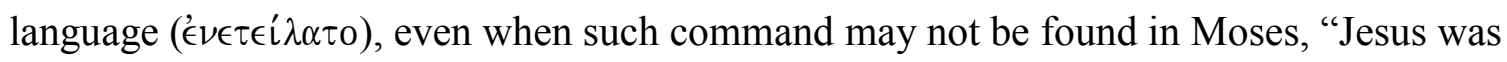
concerned about God's will," while "the others [by using "permission" language,

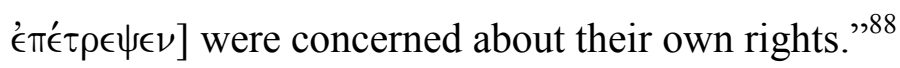

Falk makes it clear that there is no divorce language, in the legal sense, during the Hebrew patriarchal history. Prior to the Mosaic legislation, says Falk, before any

\footnotetext{
${ }^{85}$ See Boaz Cohen, Jewish and Roman Law: A Contemporary Study (New York: Jewish Theological Seminary of America, 1966), 1:31-57.

${ }^{86}$ Westerholm, Scribal Authority, 21-22.

${ }^{87}$ Healy, Mark, 196; cf. Davidson, Flame, 384.

${ }^{88}$ Schweizer, Good News, 203.
} 
provisions were explicitly given for divorce in Deut 24, "divorce was an arbitrary, unilateral, private act on the part of the husband and consisted of the wife's expulsion from the husband's house. ${ }^{\prime 89}$ Where Instone-Brewer has tried to make a case for divorce from Exod 21:10-11, ${ }^{90}$ Davidson is correct when he points out that "[Exod] 21:10-11 probably does not deal with a situation of divorce at all" since it is dealing with the case of a slave woman, not a wife. ${ }^{91}$ Moses' concessionary provision is described by Healy this way:

A bill of divorce was a man's relinquishment of legal claims on his wife, freeing her from any obligations to him and allowing her to marry someone else. This provision afforded some legal protection to a woman whose husband repudiated her, in a society where it was unthinkable for a woman to live on her own. The purpose of the bill of divorce was not to authorize divorce, but merely to limit its consequences for the woman. ${ }^{92}$

If the "test" question was about divorce proper, and Jesus opposed or was "contravening" the Mosaic legislation, why did Jesus not quote Mal 2:16? He could have given a more direct answer as to his opposition, but he did not. His statements "in the house" may appear as such, but they are not (see my comments below). For one, most interpreters believe that those statements were given to Mark's "church" ${ }^{\text {"93 }}$ or his Gentile Roman audience. ${ }^{94}$

${ }^{89}$ Ze'ev W. Falk, Hebrew Law in Biblical Times (Jerusalem: Wahrmann, 1964), 154.

${ }^{90}$ Instone-Brewer considers that the obligations of Exod 21:10-11, together with Deut 24:1-4, formed the basis for rabbinic divorce law; see "Rabbinic Teaching," 99-103; cf. Instone-Brewer, "Divorce Papyri 2," 231-232.

\footnotetext{
${ }^{91}$ Davidson, Flame, 387, 409.

${ }^{92}$ Healy, Mark, 196; cf. Boring, Mark, 286.

${ }^{93}$ See Boring, Mark, 287.

${ }^{94}$ See p.28, n. 96 .
} 
The inclusion of "Because of your hardness of heart he wrote this commandment for you" (10:5) supports the position that the "test" question may imply that someone or some people may have overlooked the Mosaic legislation by acting in a way that disregarded an explicit biblical command: "to write her a certificate/letter of divorce and [then] to send her away" (Deut 24:2; Mark 10:4). The contextual element of the Pharisees-Herodians plot (Mark 3:6; 12:13) may reveal that the Pharisaic question is a hypocritical attempt to entrap Jesus for his apparent lack of outspokenness against Herod's actions who, unlike John the Baptist, uplifted the law by calling the actions for what they were.

As the Pharisees saw it, Jesus was "downplaying" the law, which prompted them to use permission language, "Moses allowed" (10:4). ${ }^{95}$ This downgrading of the Mosaic legislation from command to permission by the Pharisees may imply that their "testing" may not have dealt with divorce proper, but to a practice in which the letter of divorce

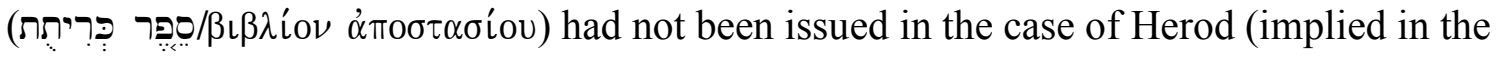
question in 10:2), ${ }^{96}$ or that the letter written by Herodias to Philip, the Tetrarch's brother, was not acceptable to religious Jews (implied in the statement in 10:12). ${ }^{97}$

By introducing Moses, Jesus was not overriding his command; on the contrary, Jesus asked whether Moses' legislation was being observed in the three-step manner in which he had stated it:

\footnotetext{
${ }^{95}$ See Banks, Jesus and the Law, 149-151; cf. Isaksson, Marriage, 21-24; G. von Rad, Deuteronomy: A Commentary, trans. Dorothea Barton (London: S.C.M., 1966), 150-153; Murray, Divorce, 31-35.

${ }^{96}$ See Josephus Antiquities 18.5.1.

${ }^{97}$ See Josephus Antiquities 18.5.4.
} 
1. "Writes her a certificate of divorce

2. Put it in her hand, and

3. Send her out of his house."

The LXX renders it thus:

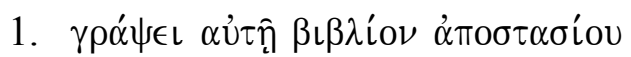

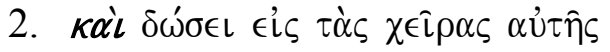

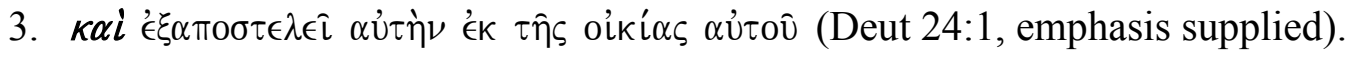

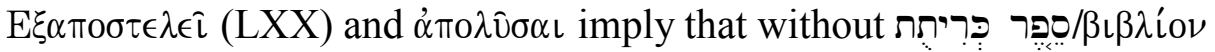

$\dot{\alpha} \pi 0 \sigma \tau \alpha \sigma i ́$ ov a proper divorce procedure had not occurred, but a mere expulsion from the home as may be envisioned in the Markan question (10:2). Du Plessis puts it this way: "The word used here for the sending away of a woman, viz. $\dot{\alpha} \pi 0 \lambda \cup \in \in \iota \nu$, is not a legal term but has the meaning of 'loosen,' 'let go' or 'free.' It bears the meaning of freeing from the possession of the man: therefore, not the dissolving of a contract between two free and equal persons but like a slave or a prisoner or some possession she [is] allowed to go [without a legal means]." 98

Hence the question, "Is it lawful for a man to $\alpha \pi \operatorname{\pi } \lambda \hat{v} \sigma \alpha \iota$ his wife?" Catchpole proposes that Jesus might as well have asked, "If Moses instructed you as to how to proceed in the question of divorce and remarriage, why are you asking if it proper for a man to leave his wife?"99 To Jesus' counter-question, Borkmann posits, “Jesus introduces

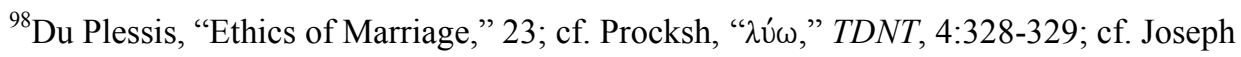
Bonsirven, Les Enseignements de Jésus-Christ (Paris: Beauchesne, 1943), 201-204.

${ }^{99}$ Catchpole, “Synoptic Divorce,” 115. Emphasis supplied. See also 121-122. 
Moses in order for the Pharisees to reflect on their own question"; ${ }^{100}$ or as Dibelius offered, it was done so that "the commandment of Moses itself is impugned in such a way as to take away the case of the opponents"; ${ }^{101}$ or as Jeremias puts it, "to annul their own argument."102 Moses in essence had said "Dismissing ( $\left(^{\prime} \xi \alpha \pi 0 \sigma \tau \epsilon \lambda \in \hat{\imath}\right)$ her without a

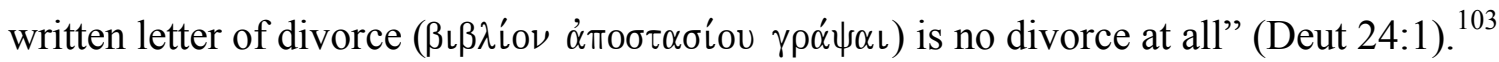
Deuteronomy 24:1-4 was written precisely to regulate a practice in which a woman was

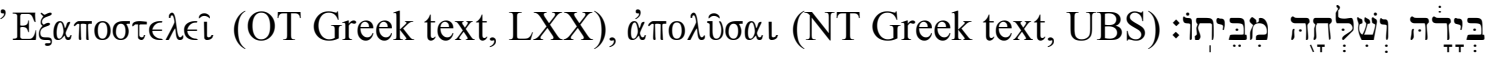

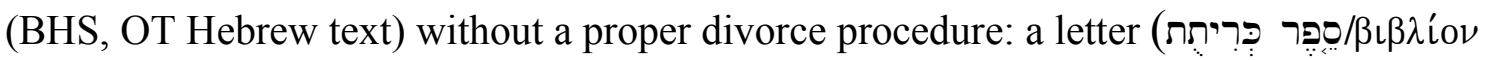

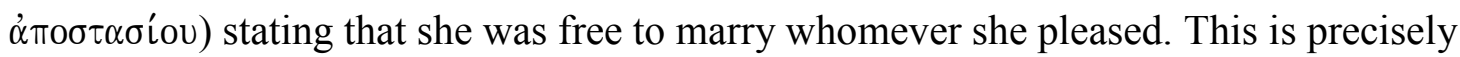
the language used in Mark (10:4): "Moses allowed a man to write a certificate of divorce

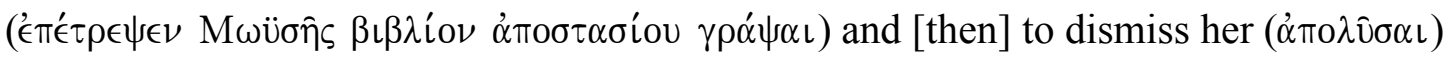
[expel or send her out of his house]."

This same grammatical construction, though in somewhat grammatically reversed order, may be found in Jer 3:8 where Yahweh follows the Mosaic procedure in his own "divorce" from Israel in which the consecutive actions may be seen in the use of kaí:

\footnotetext{
${ }^{100}$ See Günther Borkmann, Jesus of Nazareth, trans. Irene McLuskey and Fraser McLuskey (New York: Harper, 1960), 98.

${ }^{101}$ Dibelius, Tradition, 222.

${ }^{102}$ Jeremias, Theology, 1:225.

${ }^{103}$ Falk points to the usual terms for such an act: $\gamma \in \rho \cup \sigma \eta$, "to expel," and באלאהס, "to send away" (Gen 1:6; 21:10; Lev 21:7, 14;22:13). He adds that as the woman remained passive through the ordeal, the probable formula contraria used throughout biblical history may be that of Hos 4:2, "she is not my wife and I am not her husband," presumed to be spoken in the presence of witnesses. See Falk, Hebrew Law, 154. Yaron posits that it was at a later stage, beyond the patriarchal period, that the Deuteronomic dictum of the seper was given to safeguard the rights of the woman from capriciously expelling or sending away, fulfilling the function of the formula contraria. See Reuven Yaron, Introduction to the Law of the Aramaic Papyri (Oxford: Clarendon, 1961), 55; cf. Rudolf Schnackenburg, The Moral Teaching of the New Testament (Freiburg: Herder, 1965), 139-140.
} 


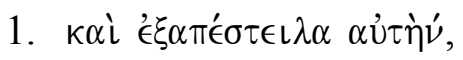

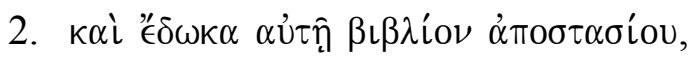

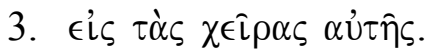

A literal translation would read: "I sent her away and gave her a letter of divorce, put it in her hand." "Deut 24.1, says Standaert, presupposes rules as to the manner on how to proceed [manière de procéder]."104

What "Moses commanded" is Jesus' emphatic way to validate the Mosaic injunction of Deut 24:1 in terms of procedure: ${ }^{105}$

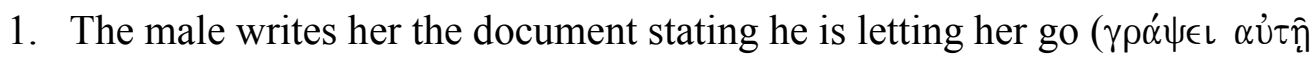
$\beta\llcorner\beta \lambda i ́ o v ~ \alpha ̇ \pi o \sigma \tau \alpha \sigma i ́ o v)$

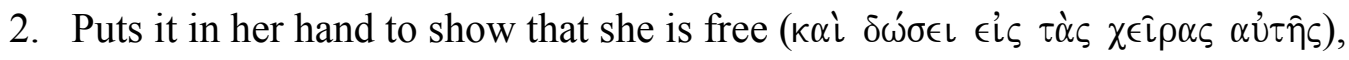

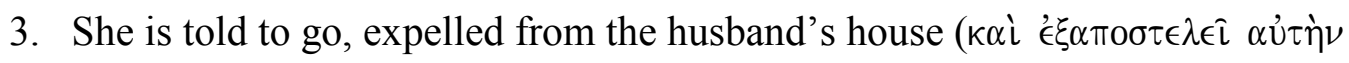

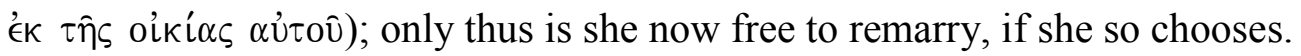

Baltensweiler notes that Jesus changes the language from expulsion $(\dot{\alpha} \pi 0 \lambda \nu \dot{v} \omega)$ in Mark 10:2, 4, 11, 12, to divorce $(\chi \omega \rho i \zeta \omega)$ in Mark 10:9. ${ }^{106}$ Boring explains that "the

${ }^{104}$ Standaert, Marc, 724.

${ }^{105}$ Such procedure in terms of its grammatical structure is best explained by Davidson in his illustration of God's non-divorce of Israel. Davidson writes: "Yahweh asks in other words, 'Where is the legal divorce document [as mentioned in Deut 24:1-4] [sic] to prove your charges?' The preponderance of commentators on this passage recognize that the hypothetical question here demands a negative answer. There is no divorce document. No divorce document-no divorce ... Judah has been 'put away' (sälaj) ... not in the sense of divorced but in the sense of going away into exile." Davidson, Flame, 411-412.

${ }^{106}$ See Baltensweiler, Die Ehe, 58-59. Elliot notes that "when Paul speaks of divorce the verb he

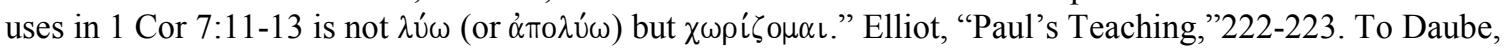

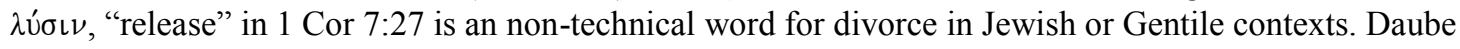
makes the additional notation where Paul uses the intransitive $\chi \omega \rho i \zeta \in \sigma \theta \alpha\llcorner$ in $7: 10$ concerning the believer wife who divorces her unbeliever husband; but when an unbeliever husband dismisses his wife, Paul uses

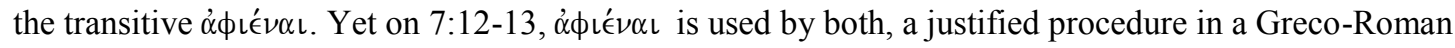


traditional translation 'divorce,' retained here for convenience [by most Bible translations], is actually too modern, and too moderate, a translation for the verb $\dot{\alpha} \pi \circ \lambda \hat{U} \omega$

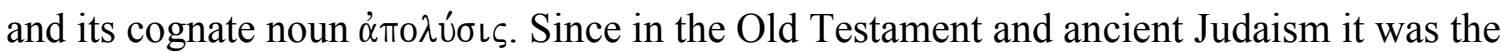
husband's prerogative, requiring no judicial decision, 'dismissal' is more accurate.",107

That the Pharisees did not press the question any longer seems to prove that Moses was being disregarded as to the divorce procedure. By pointing to Moses, the

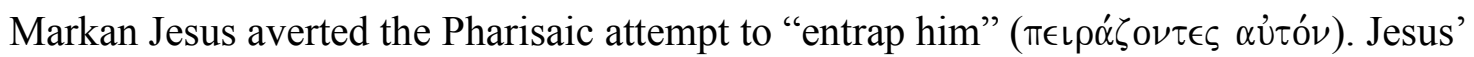
appeal to Moses annuls his opponents' arguments. The choice of words by Mark is crucial. As Jesus points to Moses, he seems to imply that those who dismiss/send away/expel their wives without the benefit of a letter of divorce were in fact "circumventing Moses or relativizing his command." 108

\section{The "Hardness of Heart" Motif}

"But Jesus said to them, because of your hardness of heart he wrote this commandment for you. But from the beginning of creation, 'God made them male and female.' For this reason a man shall leave his father and mother and be joined to his wife, and the two shall become one flesh. So they are no longer two, but one flesh. Therefore what God has joined together, let no one separate" (Mark 10:5-9). A casual glance at the structural analysis of Mark 10:5-6 (see chapter 4) shows how the "hardness of heart" of 10:5 stands in an adversative position to the male-female/one flesh motif of 10:6, 8:

setting in which "divorce by mutual agreement, common throughout the Hellenistic world, may be described as 'expelling one another."” Daube, Rabbinic Judaism, 362-363. For more, see chapter 3 above.

${ }^{107}$ Boring, Mark, 286.

${ }^{108}$ Westerholm, Scribal Authority, 350-353; cf. David Daube, "Concessions to Sinfulness in Jewish Law," JJS 10 (1959): 1-13. 
"Because of your hardness of heart he wrote this commandment for you. But from the beginning of creation ..."

The inference of Jesus' statement is that God's ideal was that of permanence of the marriage relationship, but "because of the hardness of heart" the Mosaic legislation was necessitated. Lane calls the Mosaic command on divorce "the lesser of two evils ... [and] a merciful concession for the sake of the woman"109 in a patriarchal society where women were subservient to men. Because "patriarchy was operative" and that divorce is not something to be abolished within a patriarchal structure, says Schüssler-Fiorenza, “divorce is commanded out of necessity." She elucidates on Mark 10:5, 6, and 8 as

follows:

However, Jesus insists, God did not create or intend patriarchy but created persons as male and female human beings. It is not woman who is given into the power of man in order to continue "his" house and family line, but it is man who shall sever connections with his own patriarchal family and "the two shall become one sarx." Man and woman enter into a common human life and social relationship because they are created as equals. ${ }^{110}$

Although the Mosaic command "does not set forth the absolute and perfect will of God, says Stein, “[it is] his will in light of human sin . . . a concession God permitted due to sin, due to "the hardness of human hearts for the sake of the woman,","11 a concession in which "undoing" it would not take "man" back to his Edenic ideal, ${ }^{112}$ especially when

${ }^{109}$ Lane, Mark, 355; cf. Daube, "Concessions," 1-13.

${ }^{110}$ Elizabeth Schüssler-Fiorenza, In Memory of Her: A Feminist Theological Reconstruction of Christian Origins (New York: Crossroad, 1983), 143. Cf. Diane Jacobs-Malina, Beyond Patriarchy: The Images of Family in Jesus (New York: Paulist, 1993), 33-35; and cf. Robert Hamerton-Kelly, God the Father: Theology and Patriarchy in the Teaching of Jesus (Philadelphia: Fortress, 1979), 86-89.

${ }^{111}$ Stein, Mark, 456. 
"the divine intention for marriage cannot be determined from a text on divorce." "113

Therefore, Jesus simply points to God's original intent while at the same time allowing for the Mosaic command to stand given "the hardness of heart." The "hardness of heart" manifested itself in many forms in the life of Israel. The Mosaic legislation on divorce (Deut 24:1-4) was one of many other attempts to curb the abuses resultant of his "hard-hearted" condition. Upon the rewriting of the Decalogue purportedly for a "hardhearted" violation of idolatry, God calls the people to "Circumcise, then, the foreskin of your heart, and do not be stubborn any longer" (Deut 10:16).

The "circumcision of the heart" appealed to callous husbands who at their whim ran their wives from their homes, which would ultimately require Moses, guided by Yahweh, one would suppose, to introduce this legislation on divorce. Via writes, "Mark sees hardness of heart as the condition of humanity throughout the course of world history." He goes on to highlight instances in which Jesus pointed to the hardness of the heart in cases other than divorce.

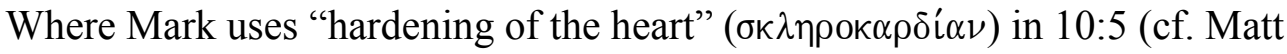
19:8), Jesus speaks of “dullness or stubbornness" ( $\pi \omega \rho \omega ́ \sigma \epsilon \iota)$ of heart in 3:5 in connection to the Pharisees' opposition to his healing of a man with a withered hand on the Sabbath in which, interestingly enough, they immediately "conspire" with the Herodians against $\operatorname{him}(3: 6)$.

Mark alludes to this dullness of heart by quoting Isa 6:9-10, "They may indeed

\footnotetext{
${ }^{112 ، " G o d ~ k n e w ~ t h e n ~[D e u t ~ 24] ~ a n d ~ H e ~ k n o w s ~ n o w ~ t h a t ~ a f f e c t i o n ~ a n d ~ t e n d e r-h e a r t e d n e s s ~ c a n n o t ~ b e ~}$ legislated, so he did the best: control it. The 'Edenic ideal' is a process of restoration in individual human hearts. Where divorce is legally prohibited, no law can reverse what has already happened in the heart." Glen G. Scorgie, Journey Back, 2005), 77-78.
} 
look, but not perceive, and may indeed listen, but not understand; so that they may not turn again and be forgiven" (Mark 4:12; cf. Matt 13:14-15). In 8:17 Jesus calls his own disciples "dull or stubborn-hearted" as they mumble about the lack of bread minutes after Jesus had fed thousands with a few loaves.

In Mark 16:14, after his resurrection, the disciples are reprimanded of their $\sigma \kappa \lambda \eta \rho о \kappa \alpha \rho \delta i \alpha \nu$ because of their unbelief. ${ }^{114}$ Daube helps us to understand this process by which on the one hand there is a law-giver, yet on the other this same law-giver is conscious of human frailty for which he makes concessions:

By concessions to sinfulness we do not mean exhortations that one should forgive and help the transgressor, as God forgives and helps him. Such exhortations are in no way intended to legalize sin. Nor do we mean the mere fact that in Judaism, as everywhere, law proper is not so co-extensive with morality or whatever ideal order may prevail. . . A All codes, including Jewish, since they deal with fallible human beings, are severely limited in their repression of evil and promotion of good; one could not, for example, impose the death penalty for each and every kind of fraud or oppression. But we would in general, because a lawgiver remains within these limitations, speak of deliberately giving in to sin. For that, the lawgiver has to be aware of, even concerned about, the shortcomings of his code. What we mean, then, is the conscious building into a law, the full recognition of the lawgiver, in spheres where in principle he would want to enforce the ideal order, of institutions or practices in conflict with it, the kind of thing Jesus declared to have happened in the case of divorce, tolerated by Moses "for the hardness of your heart."

That this "hardness of heart" may have pushed back the clock from the legislated scriptural command of Deut 24 appears to concern Jesus as he appeals to it. Viewed in context, Jesus does not seem to be concerned that the Pharisaic plot against him centers

\footnotetext{
${ }^{113}$ James R. Edwards, The Gospel according to Mark (Grand Rapids, MI: Eerdmans, 2002), 302.

${ }^{114}$ Dan O. Via, The Ethics of Mark's Gospel (Philadelphia: Fortress, 1985), 45.

${ }^{115}$ Daube, "Concessions," 1. For more on Jesus and his relationship to the law, see J. Daryl Charles, "The Greatest or the Least in the Kingdom? The Disciples' Relationship to the Law (Matt 5:17.20)," SBL (2000): 139-162; Frank Thielman, The Law and the New Testament: The Question of Continuity (New York: Crossroad, 1999), 51-58.
} 
on his theological distinctions or interpretation of Moses; for that, the Pharisees had ample opportunities to seize him, especially for Sabbath-breaking. Wenham concedes that "not all Jews interpreted the scriptures in the same way." 116 The Pharisees' disagreements with Jesus were not at the level of intellectual variations on the interpretation of the law, as Stock claims when he states that "clearly, Jesus positions himself against his contemporaries and against Jewish traditions." ${ }^{117}$ Polaski and Polaski posit that "the Torah contains very little information about divorce, offering no explicit guidance as to when divorce was appropriate and when it was inappropriate." 118 They argue that "from the hundreds of positions throughout history" as to what Moses may have meant in Torah, "they are just that, positions," whether they were uttered from a Jewish-rabbinical or Christian point of view. ${ }^{119}$ The Pharisaic debates of the time show a variety of opinions, and as far as we know, no one was ever executed for disagreeing with them. ${ }^{120}$ The Pharisees knew why the "concession" had been enacted. They knew the

${ }^{116}$ G. J. Wenham, "Marriage and Divorce," 9.

${ }^{117}$ K. Stock, Marco, 196.

${ }^{118}$ Polaski and Polaski, "Listening," 595.

${ }^{119}$ Ibid., 595. The authors add that "Deut 24 seems to understand that a wife not pleasing her husband 'because he finds something objectionable about her' is the grounds for divorce, but the phrase 'something objectionable' ('ervat dabar) can be interpreted rather restrictedly or extremely broadly, depending on the interpreter" (595n8).

${ }^{120}$ The variety of theological opinions tolerated among the Jewish rabbis has been well documented, especially by the ones of the Second Commonwealth as synagogues proliferated. For the extent of the philosophical-theological amplitude that Judaism tolerated, and the reason why Christianity and other sects proliferated by having access into the synagogue, see Paul Heger, The Pluralistic Halakhah (New York: De Gruyter, 2010), 105-107; Richard Hidary, "Tolerance for Diversity in Halakhic Practice in the Talmud" (Ph.D. diss., New York University, 2008), 78-81; Paul Heger, "Preference for Individual Opinion," in The Pluralistic Halakah: Legal Innovations in the Second Commonwealth and Rabbinic Periods (Berlin: Walter de Gruyter, 2003), 187-199; Steven Fine, ed., Jews, Christians, and Polytheists in the Ancient Synagogue: Cultural Interaction During the Greco-Roman Period (London: Routledge, 1999); Catherine Hezser, The Social Structure of the Rabbinic Movement in Roman Palestine (Tübingen: Mohr 
wide spectrum of interpretation by their rabbis. ${ }^{121}$

"The deuteronomic code on divorce," says Majors, "is conspicuous for the humanity and tenderness of its position, particularly towards those classes of the population who were peculiarly liable to be victims of injustice and oppression, namely, women." The law, according to Majors, was "intended to protect the wife from hasty and unjust treatment of abandonment and neglect which in earlier times they had been victims of heartless husbands." ${ }^{122}$ Supposing that Jesus interdicts the Mosaic practice of divorce, would Jesus consider that "heart-hardness" would come to a halt toward women/wives?

If the case of the Pharisees' "trap" against Jesus does not revolve around his (mis)interpretation of the law of divorce, one would need to look somewhere else for a motive. Jeremias seems quite precise in his contextual analysis of the Markan divorce logion when he states that "it would be wrong to deduce a diminished appreciation of marriage."

What we see is the prohibition of putting a wife away, shall we say, and not the prohibition of divorce."123 The Mosaic command was being disregarded by some people in the way it was stated. The Baptist had called "sin by it right name" and paid with his life. What did the Markan Jesus consider about this practice? The house of Herod appears to be at the heart of the Pharisaic "test."

Siebeck, 1997). For more on this, see Vermes, Jesus the Jew, 35-38; cf. Westerholm, Jesus, 43-46; Sanders, Jesus and Judaism, 245-269.

${ }^{121}$ For a brief overview in the varied ways in which the ervat dabar was interpreted by the rabbis, see Jeffrey H. Tigay, Deuteronomy: The Traditional Hebrew Text with the New JPS Translation, Jewish Publication Society (JPS) Torah Commentary (Philadelphia: Jewish Publication Society, 1996), 221-223.

${ }^{122}$ Henry D. A. Major, Thomas W. Manson, and C. J. Wright, The Mission and Message of Jesus: An Exposition of the Gospels in the Light of Modern Research (New York: E.P. Dutton, 1938), 126.

${ }^{123}$ Jeremias, Teología, 262. 


\section{The House of Herod}

"They said, 'Moses allowed a man to write a certificate of divorce, and to put her away"” (10:4). This grammatical structure generally goes unnoticed by unsuspecting English readers of the Bible. Collins highlights that $\gamma \rho \alpha \dot{\psi} \psi \alpha \iota$ and $\dot{\alpha} \pi 0 \lambda \hat{v} \sigma \alpha\llcorner$ are both "infinitives in the aorist, signifying a specific event." 124 "What did Moses command you?" (Mark 10:3). This question appears to loom large in Mark's overall thrust concerning that "specific event" in the Pharisaic-Herodian plot against Jesus. Rumor had it that Jesus was the resurrected John the Baptizer (Mark 6:14; 8:28) and that the Pharisees were aware of John's meddling at Herod's house: His marriage to a nondivorced woman (by religious Jewish standards implied in 10:12) and his failure to write a letter of divorce to Phasaelis, his Nabatean wife, ${ }^{125}$ before her departure to her father's house (implied in 10:2). John the Baptist's confrontation with Antipas over his illegal marriage to Herodias (Mark 6:18) provides a critical insight into the Pharisaic question on "divorce."

Although this suggestion has been called "unhistorical" by R. H. Charles, ${ }^{126} \mathrm{a}$ "conjecture" by Schnackenburg, ${ }^{127}$ and of "little likelihood," by Banks, ${ }^{128}$ the historical

${ }^{124}$ R. F. Collins, Divorce, 95.

${ }^{125}$ See Josephus Antiquities 15.7.10, 18.5.1; cf. Barnett, Jesus, 188-190. For more on Nabatean history, see Strabo, The Geography of Strabo, 1:16.4.23-26, trans. Horace Leonard Jones, LCL (New York: Putnam, 1917-1933); David Frank Graf, Rome and the Arabian Frontier: From the Nabateans to the Saracens (Brookfield, VT: Ashgate, 1997), 24-27.

${ }^{126}$ Charles, Teaching, 31 .

${ }^{127}$ Rudolf Schnackenburg, Die Ehe nach dem Neuen Testament: Theologie der ehe (Gottingen: Regensburg, 1969), 417.

${ }^{128}$ Banks, Jesus and the Law, 146. 
context surrounding the text seems to point only in one direction. Lane posits the following:

It seems likely, however, that far more than [a] rabbinic dispute was in the background of the question posed in verse 2 . The question was hostile in its intention. ... This larger context of temptation is very important to the passage as a whole. The question of the lawfulness of divorce and remarriage had been the immediate occasion for John the Baptist's denunciation of the conduct of Herod Antipas and Herodias (6:17f) and had led to a violent death. In Perea Jesus was within the Tetrarch's jurisdiction. The intention behind the question, apparently, was to compromise Jesus in Herod's eyes, perhaps in the expectation that the Tetrarch would seize him even as he had John. The cooperation between the Herodians and Pharisees, first mentioned in Ch. 12:13, may be part of the historical situation presupposed in the narrative. ${ }^{129}$

If Lane's analysis is correct, and since no other event appears to fit within its context, than the "test" question is hardly one which refers to divorce, but rather, to desertion and/or expulsion. The traditional rendition of the Pharisees states, "Is it lawful for a man $(\dot{\alpha} \nu \delta \rho \hat{\imath})$ to divorce $(\dot{\alpha} \pi 0 \lambda \hat{v} \sigma \alpha \iota)$ his wife $(\gamma \nu \nu \alpha \hat{\imath} \kappa \alpha)$ ?, testing Him.” The androcentric nature of the test question in 10:2 may point to Antipas's actions toward Naphaelis, his Nabatean wife, the daughter of king Aretas IV. Mahoney argues that the statement, "he [Jesus] left that place and went to the region of Judea and beyond the Jordan" (Mark 10:1), places Jesus in Nabatean territory, the place of the Pharisaic confrontation. ${ }^{130}$ Barnett states: “Antipas's eastern frontier, Perea, faced the formidable inland kingdom of the Nabateans."

The fortress Machareus in the mountains east of the Dead Sea was critical to Antipas's defenses against this desert people. So, too, was his inter-dynastic marriage to

${ }^{129}$ Lane, Mark, 353-354.

${ }^{130}$ Aidan Mahoney, “A New Look at the Divorce Clauses in Matt 5,32 and 19,9,” CBQ 30 (1968): 33. 
the daughter of their king, Aretas IV."131 Antipas's father, Herod the Great, part Idumean and part Nabatean, was a man who had adopted Judaism to a certain degree, but who had otherwise embraced Hellenism. His name, as well as that of his grandfather (Antipater), was Greek. Herod Antipas, the tetrarch of Galilee and Perea, appropriated the Hellenistic way of life and world view. He built Tiberius along Hellenistic architectural, political, and educational lines. But Antipas had greatly offended Jewish scruples. He also allowed the city to be inhabited mainly by Gentiles. ${ }^{132}$

As to his Hellenistic “divorce," Antipas's attitude fits the Roman practice, since "divorces . . . occurred by common consent, or by the unilateral action of the husband or the wife after a sending of an official notice, or by simple declaration before a judge, or even through third parties."133 Berger and Nicholas write of Greco-Roman marriages as being "a matter of fact" and that the marriage could be dissolved bilaterally "by simply terminating the facts." 134 Thompson states that "[Roman] divorce was easily attainable, either by mutual consent or through an action on behalf of either one of the spouses, and there was no stigma attached."135

When divorce was initiated by the husband, he was required merely to send her

${ }^{131}$ Barnett, Early Christianity, 188.

${ }^{132}$ See Josephus Antiquities 18.2.3.

${ }^{133}$ Albrecht Oepke, “ $\gamma \nu \nu \epsilon, ”, T D N T, 1: 778$.

${ }^{134}$ Berger and Nicholas, "Marriage, Law of," 649-650; cf. Weibling who states that "Roman marriage ... had no legal character. All was necessary was living together of a man and a woman with the intention of forming a lasting union." James M. Weibling, "Reconciling Matthew," 223. Good summaries of Greco-Roman divorce laws may be found in Suzanne Dixon, The Roman Family (Baltimore: Johns Hopkins University Press, 1992), 66-81; Jane F. Gardner, Women in Roman Law and Society (London: Croom-Helm, 1987), 81-95. For a full treatment of Hellenistic-Roman divorces, see chapter 3. 
away, yet when she wanted a divorce, her father or male guardian interceded on her behalf. ${ }^{136}$ Instone-Brewer puts it simply: "In Graeco-Roman law, separation with intention to end the marriage was divorce."137

It is implied in the Markan text that Herod Antipas did not go through the normal Jewish practice of divorcing his Nabatean wife by giving in writing an attestation of a formal separation. Hoehner entertains the notion that when Antipas's Nabatean wife heard of the tetrarch's plans to divorce her in order to marry Herodias, she fled back to her father without a legal separation. ${ }^{138}$ If this is so, the Jewish view-which was also the view of the Baptizer and of Jesus and which eventually cost the Baptizer's head—appears to be in direct correlation with the concept that Antipas did not abide by Moses' command to write his wife a letter of divorce while taking as wife a woman considered to be still married to her husband, Antipas's own brother.

Jesus' statement in Mark 10:11-12 makes perfect sense in which a woman who remarries without the benefit of the letter of divorce, in Herodias' case, she commits adultery or in Naphaelis' case, she is made to commit adultery. This action, according to Josephus, ${ }^{139}$ caused Aretas IV to invade Antipas's territory in 36 C.E. in retaliation for rejecting his daughter, an invasion which eventually brought the tetrarch's downfall.

Josephus describes how devout Jews interpreted this as divine retribution for

\footnotetext{
${ }^{135}$ W. E. Thompson, “Athenian Marriage Patterns: Remarriage,” California Studies in Classical Antiquity 5 (1972): 212.

${ }^{136}$ See Lefkowitz and Fant, Women, 59-60; cf. Sarah B. Pomeroy, Goddesses, Whores, Wives, and Slaves: Women in Classical Antiquity (New York: Schoken, 1975), 62-64.

${ }^{137}$ Instone-Brewer, “Divorce Papyri 1,” 106.

${ }^{138}$ See Hoehner, Herod Antipas, 131-136.

${ }^{139}$ See Josephus Antiquities 18.5.1.
} 
having killed John the Baptist as Antipas seemed to live content with his new life after the Baptist's demise. ${ }^{140}$ The historical reconstruction of Hoehner and others contains all the necessary ingredients as to make Antipas's actions the main "test" of the Pharisaic encounter, ${ }^{141}$ for as Hays asserts, "Jesus' debate with the Pharisees over divorce law occurs within a politically charged atmosphere."142 Bowman has noted that the Pharisees rely on Antipas's support while Jesus is in Perea as they counsel with the Herodians as to how to entrap him (Mark 3:6). As the Pharisees miss another opportunity to bait him (in the "divorce" encounter in Mark 10:2-9), they are at it again later as he arrives in Jerusalem (see Mark 12:13, par. Matt 23:15). ${ }^{143}$

Meier provides us with an insight that points to the Pharisaic question in a direction in which Jesus understood the question as one that did not imply divorce. Meier notes, that "technically speaking, the precise question asked by the Pharisees in v.2 is never answered by Jesus with the same vocabulary anywhere in the rest of the dispute." Meier notes that the question, "'Is it lawful for a man to divorce his wife (ei exestin andri gynaika apolusai)'? . . especially the key verb 'divorce' ('̊no $\lambda$ ú $\omega)$, disappears from the rest of the dispute with the Pharisees" and that the $\alpha \pi 0 \lambda \dot{\omega} \omega$ language of the Pharisees' is picked up again only "when Jesus retires to the house." 144 That Jesus was not ready to

\footnotetext{
${ }^{140}$ See Josephus Antiquities 18.5.2; 18.7.2-5.
}

${ }^{141}$ See Hoehner, Herod Antipas, 199-202; cf. Neufeld, "Marriage after Divorce," 31; Joseph B. Tyson, "Herod Antipas," 230-246; Josephus Antiquities 18.5.1; 18.7.2; Josephus Josephus 9:147-149; Stein, "Is It Lawful," 116-118; Jeremias, Teología, 262.

${ }^{142}$ Richard B. Hays, The Moral Vision of the New Testament: A Contemporary Introduction to New Testament Ethics (San Francisco: HarperSanFrancisco, 1996), 350.

\footnotetext{
${ }^{143}$ Bowman, Mark, 208.

${ }^{144}$ Meier, Law and Love, 4:120. Emphasis supplied.
} 
compromise himself publicly concerning the Herod-Herodias affair can be seen in that he brings his denunciation against it "in the house" (Mark 10:12) with the disciples.

It has been pointed out elsewhere in this dissertation ${ }^{145}$ what many scholars consider to be the intent of the Gospels' saying on divorce: That Jesus is restoring the divine ideal for marriage as expressed in Gen 1-2. In Mark's statement, "But Jesus said to them, 'because of your hardness of heart he wrote this commandment for you. But from the beginning of creation, 'God made them male and female.' 'For this reason a man shall leave his father and mother and be joined to his wife, and the two shall become one flesh.' So they are no longer two, but one flesh. Therefore what God has joined together, let no one separate"” (Mark 10:5-9), Jesus has in essence annulled Moses and restored marriage to its original state to a world of no more divorces. Many scholars have not

found any legal pronouncements in Jesus' statement. ${ }^{146}$ What the text seems to imply, however, is Jesus lamenting the fact that Moses had to legislate divorce for "the hardness of heart." What I see here is Jesus deploring the fact that God's original intention had eroded to the point where a man and a woman are simply abandoning their spouses without following the proper Mosaic legislation, as we shall see in Jesus' explanation "in the house" (Mark 10:10-12).

\section{"In the House"}

"And in the house the disciples asked him again about this matter" (Mark 10:10). Private consultation of the disciples is a redactional trend of Mark's Gospel in which

\footnotetext{
${ }^{145}$ See p. 160, n. 76 ; pp. $186-187$, notes $176-179$.

${ }^{146}$ See p. 9 , n. 20 .
} 
Jesus seeks to instruct them or in which the disciples seek further clarification whether when "he is alone" with them on a mountain, in a boat $(4: 10 ; 6: 51 ; 8: 1310: 23-31 ; 13: 3$; $14: 17 \mathrm{ff}$.$) , or "in the house" (7: 17 ; 9: 28 ; 10: 10)$. This Markan thrust is basic to his portrayal of the disciples being "slow to understand" $(4: 12,13 ; 6: 52 ; 8: 17,21 ; 9: 32)$. As in previous occasions, the disciples' inability to catch the intention behind the "test" question or Jesus' answer to the Pharisees causes them to ask him again "in the house" $(10: 10)$.

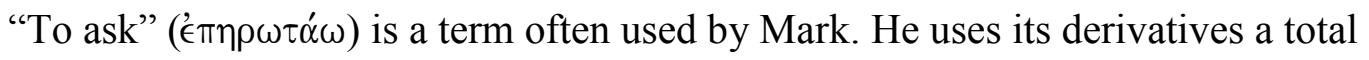
of twenty-five times (28 times in the rest of the NT). When the verb occurs in Matthew and Luke, they parallel Mark. "These considerations — adds Collins_-make it clear that it was Mark, the creative writer, who appended the instruction of the disciples to the account of the discussion with the Pharisees on the question of divorce,"147 contrary to those who adopt the view that Mark "adapts the tradition to fit his missionary concern," $" 148$ or such saying was "unintelligible to a Jewish audience, and it is difficult now to determine what they mean in their original, non-modern sense." ${ }^{149}$ Whatever Jesus may have added to the laconic report in Mark 10:11-12, it appears to satisfy the disciples' concerns. $^{150}$

${ }^{147}$ R. F. Collins, Divorce, 73.

${ }^{148}$ Martin, Mark, 221; cf. Stein, Mark, 457, who comments that there is also no biblical evidence either in Mark or Paul of porneias as an exception; that porneias is Matthew's attempt to adapt Mark's teaching, rather than Mark making Matthew's saying more difficult.

${ }^{149}$ Bailey, Mystery, 90; cf. Berger, who also distinguishes Mark 10:10-12 as being a later addition to the original pericope, and considers Mark 10:9 more historical than 10:2-8. K. Berger, Jesu, 576; and Schweizer, Good News, 201.

\footnotetext{
${ }^{150}$ There is no evidence in the Gospels as to whether the disciples were aware of the HillelShammai debates assumed in Matthew. Jesus' public explanation to the disciples' public question in
} 
"And he said to them, 'Whoever divorces his wife and marries another, commits adultery against her; and if she divorces her husband and marries another, she commits adultery." Mark 10:11-12 is certainly an awkward statement within the Jewish religious environment. ${ }^{151}$ That the traditional Christian interpretation has been imported into the text may be seen in statements such as: "Jesus is only talking about believing persons whom God has joined together [and that] he says nothing about pagan marriages."152 Nydam quips: "[In Mark 10:11-12] the Mosaic concession is confronted. . . . There are no exceptions anymore, no backdoor exists out of marriage because another woman or man may be found 'pleasing to the eyes.' Jesus tightens the reins and proclaims the will of his Father, that God hates divorce and will no longer allow what Moses allowed."153

When it comes to the grammar in 10:12, Stein, among others, believes that ' $\epsilon$ '

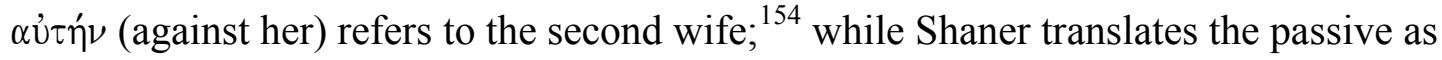
"she is being made a committer of adultery." $" 155$ Witherington, in one broad stroke, erases a long history of Jewish practice in which a man may marry more than one wife, so long as she is a single or properly divorced woman, ${ }^{156}$ when he adds in agreement with Stein:

Matthew (19:10-12) contains no reaction that hinted that he was against the Jewish interpretation of Moses. Whatever happened in that house that day did not reveal "the true deeper meaning that is already contained in the law," vis-à-vis, that God never approved divorce. See Davidson, Flame, 656; cf. 400-402. Roman setting.

${ }^{151}$ Reasons as to why many commentators place Mark 10:12 as an addendum pertaining to a

${ }^{152}$ Witherington, Mark, 277.

${ }^{153}$ Nydam, “Messiness,” 219-220.

${ }^{154}$ Stein, Mark, 458; cf. Witherington, Mark, 277; Robert H. Gundry, Mark: A Commentary on His Apology for the Cross (Grand Rapids, MI: Eerdmans, 1993), 541-542.

${ }^{155}$ Donald W. Shaner, A Christian View of Divorce (Leiden: Brill, 1969), 44.

${ }^{156}$ See Stein, Mark, 458; cf. Phillip Sigal, "Elements of Male Chauvinism in Classical Halakah," Judaism 24 (Spring 1975): 233. 
"This makes sense, for adultery is by definition an act committed by a married person with a third party.",157

In a quote/paraphrase of Painter, ${ }^{158}$ Witherington states again: "Painter is right that the upshot of the teaching here is that while Jesus recognizes the realities of divorce, he does not think this legitimizes remarriage if the original couple were joined together by God in the first place." ${ }^{159}$ And to erase any doubt as to what Jesus meant, Healy states: "On his own authority Jesus has just taken away a concession given in the law of Moses. ${ }^{\prime 160}$ Lövestam takes the statement a little bit farther and identifies Mark 10:12 with the exception clause of Matt 19:9 as equivalent statements for both Gentile and Jewish women. He says: "This clause [in Matt 19:9] is thus equivalent in the Jewish framework of Mk. 10:12 in the Graeco-Roman cultural environment, when the logion on the man's guilt in this connection follows: .. . 'and if she divorces her husband and marries another, she commits adultery.", 161

If these concepts were intended by Jesus they would totally radicalize Jewish marriage and divorce ethics since in Judaism no adultery charge is known to be brought against a man who marries a single, widowed or properly divorced woman, and neither can it be brought against a single or properly divorced woman who marries any man,

\footnotetext{
${ }^{157}$ Witherington, Mark, 277. Davidson, though referring to Matt 5:32, considers "that the husband's putting away his wife has in effect caused her to defile herself in a second marriage in a similar way as if she were committing adultery," Davidson, Flame, 656.

${ }^{158}$ Painter, Gospel, 142.

${ }^{159}$ Witherington, Mark, 277.

${ }^{160}$ Healy, Mark, 198.

${ }^{161}$ Evald Lövestam, "Divorce and Remarriage in the New Testament," in The Jewish Law Annual 4, ed. B. S. Jackson (Leiden: Brill, 1981), 61.
} 
single or married. ${ }^{162}$ But "Jesus seems to assume that the first one-flesh union is still in force even after the divorce, hence the second marriage is an act of adultery, but that, against the normal use of the term in antiquity, it is the man who is called an adulterer,"

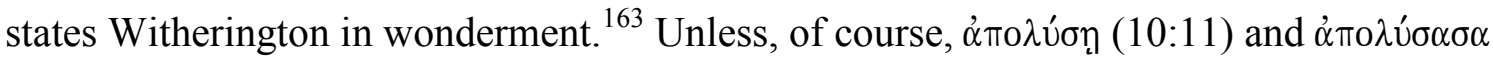
(10:12) are to be read "to dismiss/send away" without the benefit of a written document, which is not divorce at all as appraised in the original question, for a "very famous example of Mark 10:12 existed in Galilee," admits Stein. ${ }^{164}$ On the one hand Antipas becomes the "adulterer" here (Mark 10:11) for taking as wife a woman still considered to be married in Jewish eyes ${ }^{165}$ in view of Herodias's unacceptable divorce to her husband, Philip. ${ }^{166}$ On the other hand, Antipas causes Naphaelis, his Nabatean wife, to commit adultery (Mark 10:12) should she remarry, for he does not appear to have given to her a letter of divorce, as Hoehner suggests. ${ }^{167}$

Almost fifty years ago, Diderichsen read Mark 10:11-12 as follows: "Anyone who leaves his wife and marries a married woman commits adultery against her, and if she leaves her husband and marries another man, she commits adultery." ${ }^{168}$ Diderichsen

${ }^{162}$ For a detailed Rabbinic teaching on the issue, see Instone-Brewer, "Rabbinic Teaching," 85-88.

${ }^{163}$ Witherington, Mark, 278.

${ }^{164}$ Stein, Mark, 458.

${ }^{165}$ Josephus Antiquities 15.7.10.

${ }^{166}$ The relationship between Mark 10:2 and 10:11-12 may be best appreciated in the connectors of the structural analysis in chapter 4.

${ }^{167}$ See Hoehner, Herod Antipas, 131-136; cf. Josephus Antiquities 18.5.1.

${ }^{168}$ Børge Krag Diderichsen, Den markianske skilmisserpericope: Dens Genesis or historike placering (Gyldendal: Aarhuus stiftsbogtrykkeril, 1962), 47; Fitzmyer, "Matthean Divorce," 211. Translation thanks to http://translate.google.com/\#. It was, however, verified by Neils-Erik Andreasen. My subsequent comment was also done in consultation with Andreasen. 
suggests that this rendering was lost in time and that the saying was later interpreted to refer to divorce, based mainly on the Matthean account. ${ }^{169}$ Although Diderichsen's rendition may not have made an impact at the time he wrote it, no other contextual/exegetical meaning outside of the Antipas-Herodias relationship may be extracted from the Markan background that could have elicited the "test" question by the Pharisees in a period when the practice of divorce was a matter of debate as to the reasons for it, not over its illegality, as attested by the Mishnah and the Talmud (Gittin).

As noted above, there is a Pharisaic-Herodian plot to ensnare Jesus throughout the Markan Gospel, in one form or another. In Mark 10:2-12 the Pharisees laid one more trap before him. It did not work. Jesus did not reveal anything that might have given them reason to incite an arrest. He said nothing against Moses, said nothing against rabbinic interpretation, and made no overt attack on the house of Herod.

Mark reports a series of traps that are set before Jesus in a consecutive manner. They try to bait him with the question as to whether or not to pay taxes to Caesar $(12: 13-$ 17). He eludes this one also. The Sadducees are present and they also set out their own trap. Their theological question concerning marriage after the resurrection (12:18-27) assumes that a man may bring another wife to his household - a dead brother's wife, but a wife, nevertheless. ${ }^{170}$ Again, Jesus does not stumble. He does not say anything against

\footnotetext{
${ }^{169}$ Diderichsen, Den markianske, 47, 347. Fitzmyer calls this interpretation "far-fetched," in "Matthean Divorce Texts," 212. Fitzmyer's rebuttal of Diderichsen is based on a second-century CE Greek text of Murabba'at Cave II (Bar Kochbah period) where $\dot{\alpha} \pi 0 \lambda \hat{v} \sigma \alpha \iota$ refers to a divorce. He writes, "[This finding] should put to rest any hesitation about whether the Greek verb $\alpha \pi \circ \lambda \psi \epsilon \nu$ could have meant 'divorce' in the Greek of Palestine." Yet this Greek text is almost 100 years removed from the NT and too scant a statement to "put to rest any hesitation" that $\alpha$ đก $\lambda \dot{v} \omega$ means divorce.

${ }^{170} \mathrm{~A}$ clear reference to the Mosaic legislation known as "the law of levirate" (Deut 25:5-6). For a detailed explanation of this law, see Davidson, Flame, 465-467; cf. Donald A. Leggett, "The Levirate in
} 
the levirate law; his response concerning marriage in heaven leaves them pulling their beards. They are not finished yet. Mark reports that immediately a scribe ${ }^{171}$ chimes in with the question: "Which commandment is the first of all?" (12:28).

Rather than contradicting anything that Moses may have written, it is not surprising to find Jesus reaffirming what he wrote, as one would expect (12:29-34). Mark ends this series of entrapments with the short sentence: "After that no one dared to ask him any question" (12:34). The Pharisees and scribes knew that nothing that they would "test" him with would ever entangle him to the point of his compromising himself in some way or that they would ever catch him in anything that would be worthy of death. In spite all their attempts to entrap him, the Pharisees do not seem to have a direct hand in Jesus' arrest, trial and execution, ${ }^{172}$ but the Tetrarch did (see Luke 23:11; Acts 4:27).

\section{Application and Conclusion}

There is absolutely no denial that God's ideal for marriage is one of permanence.

There is absolutely no denial that all children would grow up to be perfectly balanced because they were brought up in stable two-parent ${ }^{173}$ Christian home. There is absolutely

Israel," in The Levirate and Goel Institutions in the Old Testament: With Special Attention to the Book of Ruth (Cherry Hill, NJ: Mack Publishing, 1974), 29-62.

\footnotetext{
${ }^{171}$ Whether scribes belonged to the sect of the Pharisees, as Mark seems to suggest (2:16), there is no certainty. In the Gospels, where "Scribes and Pharisees" are almost always addressed together, they still appear to be separate groups. In Matt 23 both scribes and Pharisees are the recipients of scathing "woes" from Jesus; scribes are perhaps mentioned first because they had a direct hand in the arrest, trial and execution of Jesus. For more on the scribes, see Christine Schams, Jewish Scribes in the Second-Temple Period (Sheffield, UK: Sheffield Academic Press, 1998), 29-31; cf. Anthony J. Saldarini, Pharisees, Scribes and Sadducees in Palestinian Society (Wilmington, DE: M. Glazier, 1988), 241-275.

${ }^{172}$ See H. Maccoby, The Mythmaker: Paul and the Invention of Christianity (London: Weidenfeld \& Nicholson, 1986), 45-49, 208-210; cf. D. A. Hagner, The Jewish Reclamation of Jesus (Grand Rapids, MI: Zondervan, 1984), 23-29.

${ }^{173}$ As in mom and dad, given the realities in our time in which "two-parent homes" may no longer imply two people of different genders.
} 
no denial that in God's perfect Edenic world there would be no divorce and no remarriage. There is absolutely no denial that in a perfect Edenic world twenty-firstcentury Christians would have no need for rebuke, teaching, and exhortation in all areas of human behavior. The fact is that rebuke, teaching, and exhortation are there in each and every one of the NT epistles for twenty-first-century Christians. ${ }^{174}$ Therefore, those ${ }^{175}$ who insist that the "divorce" question in the Gospels concerns Jesus' reintroduction of the "divine [Edenic] ideal" by prohibiting divorce ${ }^{176}$ may mean the following:

1. They would force us to reject the notion that "those who are sanctified in Christ Jesus, called to be saints" (1 Cor 1:2) are still capable of committing atrociously immoral acts (1 Cor 5:1-13.). When Healy states that "he [Jesus] is saying, in effect, that the concession in Deuteronomy no longer applies because humanity is no longer captive to sin, hardness of heart, and the resultant family breakdown," and "because through the cross and resurrection he is now giving them [Christians] power to live according to God's original plan, ${ }^{177}$ or Moloney's "as Jesus breaks onto the scene proclaiming the advent of the kingdom of God (1:14-15), the restoration of God's original design

\footnotetext{
${ }^{174}$ The nascent Christian Church is portrayed as one with serious hard-hearted conditions by John the apostle in his messages to the seven churches of Revelation.

${ }^{175}$ See notes $176-179$ below.

${ }^{176}$ Nydam echoes many in the Church today when he states: "The Mosaic concession is confronted in Mark. ... There are no exceptions anymore, no backdoor exists out of marriage ... Jesus tightens the reins and proclaims the will of his Father, that God hates divorce and will no longer allow what Moses allowed." Nydam, "Messiness," 219-220.

${ }^{177}$ Healy, Mark, 197-198.
} 
initiated," ${ }^{, 178}$ we ask, in what Christian community can we find the realities of God's Edenic kingdom absolutely restored? In which Christian church or institution is $\sigma \kappa \lambda \epsilon \rho о \kappa \alpha \rho \delta i \alpha$ no longer an issue? The fact is that the legislation of morality within the church calling for a "higher theology and a tougher ethic" $" 179$ does not neutralize the hardness of human hearts. We do acknowledge that with the coming of Jesus the kingdom of God was inaugurated, but the realities within the Christian church certainly show that such kingdom has not been consummated. ${ }^{180}$ Yoder makes a propos statement when he writes:

Jesus did not come to teach a way of life, most of his guidance is not original. His role is that of Savior and for us to need a Savior presupposes that we cannot live according to his stated ideals. Luther's usus elenchticus the function of the law is less to tell us what we can do to bring us to our knees because we cannot do it. ${ }^{181}$

2. We would have to ignore the long Israelite-Jewish history in which divorce

and remarriage was practiced within the parameters of the Mosaic legislation. ${ }^{182}$

${ }^{178}$ Moloney, Mark, 194.

${ }^{179}$ See Nydam, "Messiness," 211-226.

${ }^{180}$ See Charles Harold Dodd's original propositions on the nature of God's Kingdom in The Interpretation of the Fourth Gospel (Cambridge, UK: University Press, 1953) and subsequent treatments of the same topic in Clifton C. Black, "Mark as Historian of God's Kingdom," CBQ 71 (January 2009): 64-83; N. T. Wright, "Jesus and the Coming of God's Kingdom," in Simply Christian: Why Christianity Makes Sense (New York: HarperCollins, 2006), 91-104; Joel Marcus, The Mystery of the Kingdom of God (Atlanta: Scholars, 1986), 78-97; Bruce Chilton, The Kingdom of God in the Teaching of Jesus (Philadelphia: Fortress, 1984), 49-51; Kelber, Kingdom, 33-35; Richard H. Hiers, The Kingdom of God in the Synoptic Tradition (Gainesville: University of Florida Press, 1970), 13-16; Albert Schweitzer, The Kingdom of God in Primitive Christianity, trans. L. A. Garrard (London: Black, 1968), 73-75; Gösta Lundström, The Kingdom of God in the Teaching of Jesus, trans. Joan Bulman (Richmond: John Knox,1963), 44-46; George Eldon Ladd, The Gospel of the Kingdom (London: Paternoster, 1959), 52-54; F. F. Bruce, “The Kingdom of God: A Biblical Survey," Evangelical Quarterly 15 (1943): 263-268. 1994), 18.

${ }^{181}$ John Howard Yoder, The Politics of Jesus:Vicit Agnus Noster (Grand Rapids, Mich.: Eerdmans, ${ }^{182}$ Not only in the biblical data, but extra-biblical sources point to this fact as attested in the
Mishnah, Talmud, and the Aramaic and Greek papyri. See Instone-Brewer, "1 Corinthians 7 in the Light of
the Jewish, Greek, and Aramaic Marriage and Divorce Papyri," 225-243; Instone-Brewer, "Jewish Women 
3. We would have to reject the centuries of rabbinic discussion in which Moses was one of the principal sources of their interpretations, ${ }^{183}$

4. Atomistic analyses would force us to extract the Gospels' accounts from their cultural contexts in space and time, robbing them of their contextual flow and the cohesive unity in which they were written. ${ }^{184}$

To this final end, Mark was careful to document every instance in which there was a trap that sought to have Jesus compromise himself against someone or something. The "divorce-test" question is just one more trap. Had any of the previous traps or any of the following ones done its work, the Pharisees would have been satisfied.

The "divorce-test" trap was not more important than the others as to its objective. ${ }^{185}$ The Pharisees tried to entrap him with each new attempt. As the previous one did not achieve its end, they kept pressing. That Mark says nothing more about that

Divorcing," 349-357; Instone-Brewer, "Marriage and Divorce," www.tyndale.cam.ac.uk/Brewer/ marriagepapyri/; Yaron, Aramaic Papyri, 55-62; Pierre Benoit, Jozef T. Milik, and Roland de Vaux, Les grottes de Murabba'ât, The Discoveries in the Judean Desert (Oxford: Clarendon, 1961), 2:109-117; Arthur S. Hunt, ed., and C. C. Edgar, trans., Select Papyri (New York: Putnam, 1932-1934), 2:47; Arthur Ernest Cowley, ed., Aramaic Papyri of the Fifth Century B. C. (Oxford: Clarendon, 1923), 33.

${ }^{183}$ Neufeld notes, for example, that those first century Jewish (Hillel-Shammai) debates were "not the crucial issue that Synoptic commentators sometimes make [them] out to be" and notices that "the Mishnah's Gittin ('Bills of Divorce') has seventy-five paragraphs, and only one, and the very last one at that (9.10) reports in a few lines some different opinions regarding the interpretation of 'unseemly thing' [which looms large in every discussion on divorce]. The other seventy-four paragraphs give details of valid or invalid divorces, and assume that divorce is always available. ..." Neufeld, "Marriage after Divorce," 26. For a summary of the general attitudes towards divorce and remarriage in Judaism during the time of Jesus, see Instone-Brewer, "Rabbinic Teaching," 85-132.

${ }^{184}$ No one could have said it better than Bartling when he states: "There is a strong tendency to lift them [all of the teachings of Jesus] out of their kerygmatic context and to reformulate them into a universal code for pastoral care and church discipline. A touchstone for this tendency would obviously be the interpretation of those passages in the Synoptic Gospels and in 1 Corinthians 7 which deal with divorce and remarriage." Bartling, "Sexuality," 363.

${ }^{185}$ To those who attempt to make the divorce question central in the Synoptics teaching, Neufeld corrects us all when he says, "I suggest that in no Synoptic divorce saying is any Jewish debate the primary historical background." Neufeld, "Marriage after Divorce," 26. 
specific theological concern shows that it was not a different interpretation they were seeking.

In the "divorce-test" the Pharisees were hoping he would compromise himself against the house of Herod. In the Markan contextual flow, it does not appear that Mark 10:2-12 contains any other instance where Antipas and Herodias are not the main subjects. The Markan Jesus approaches the test question with the perspective that HerodHerodias original marriages are still intact when they come together as husband and wife. In either case, the Baptist had become a destabilizing factor to Antipas's Hellenistic way of life. To John, and subsequently to Jesus, Herodias was still married. Herodias's action to write her husband, Philip, a letter of divorce in order to marry Antipas was contrary to Moses and the Jewish traditions. ${ }^{186}$ When the Baptist pointed to the right observance of Torah, he lost his head.

The "test" question of the Pharisees (in counsel with the Herodians, Mark 3:6; 12:13) contemplates the same fate for Jesus as described in the Lukan account, "Herod wants to kill you" (Luke 13:31). Word got around that John the Baptist was alive again roaming Antipas's district (Mark 6:16), and perhaps would show up at his doorstep again to accuse him of having a married woman for a wife, in Jewish and John's and Jesus' eyes. Her actions were interpreted as having deserted her husband, Philip, in order to marry Herod Antipas, her brother-in-law. ${ }^{187}$ The Antipas-Herodias affair broke away from the basic understanding within a Jewish environment that "a woman properly

\footnotetext{
${ }^{186}$ Josephus Antiquities 15.7.10.
} 
divorced was available for remarriage without fear of adultery on anyone's part: this was (and remains) the common Jewish view." ${ }^{" 188}$ Without this contextual understanding of the pericope it would seem very difficult to consider any other interpretation for the "trap" and the "test" question against Jesus.

"Every society has one unforgiveable sin," writes N. T. Wright. ${ }^{189}$ The Christian church has certainly made subsequent remarriages, other than the sexual sin of the spouse, its unforgivable sin, thus leaving those who have divorced without a "just cause" (meaning adultery) in a perennial state of adultery. To imply that the Markan Jesus "leaves no loopholes" for divorce as the Matthean Jesus does, because "what Moses commanded the historical Jesus rejects" $" 190$ or that "it is on the authority of Scripture that he [Jesus] denies the validity of the interpretation of Deut 24:1, which gives approval to divorce," ${ }^{, 191}$ may be deemed unacceptable in view of the overwhelming contextual evidence that divorce, proper, was not envisioned in the Markan Pharisaic encounter with Jesus, but rather, the complete disregard for the Mosaic legislation on the part of the ruler of Northern Palestine: The house of Herod.

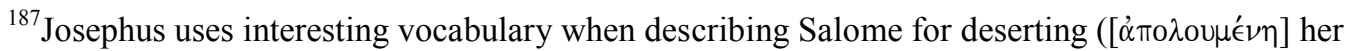

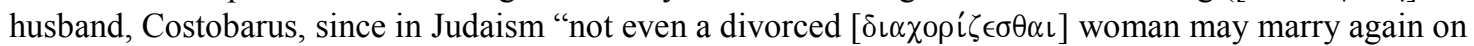
her own initiative unless her former husband consents." Josephus Antiquities 15.7.10; cf. 18.5.4 and 15.7.9.

${ }^{188}$ Derret, Law, 371.

${ }^{189}$ Wright, Simply Christian, 93.

${ }^{190}$ Catchpole, "Synoptic Divorce," 120.

${ }^{191}$ John Wenham, Christ and the Bible (Grand Rapids, MI: Baker, 1994), 34, italics are his.
} 


\section{CHAPTER 6}

\section{CONCLUSION}

The Christian Church has historically relied on the Gospel of Matthew in its efforts to understand and apply Jesus' teaching on divorce. The Church, in general, has not weighed the importance of Mark's contributions on the subject and, when it has considered them, the Markan Jesus is portrayed somewhat less tolerant of divorce for not providing any exceptions to its practice.

The goal of this dissertation, therefore, has been to ascertain what the Jesus according to Mark (10:2-12) may have taught about divorce. In my attempt to understand what Mark may have understood about Jesus' teaching on the subject, a teaching that he transmitted to his Palestinian Gentile audience, the proposed method was to conduct a contextual analysis of the Markan pericope in order to grasp the progression of the evangelist's narrative as he understood Jesus' relationship with and toward the Pharisees (and vice versa) that culminated in one more confrontation with this sect in which they try, once again, to pin him against the proverbial wall, this time with the question: "Is it lawful for a man to divorce his wife?" (Mark 10:2).

In chapter 1, I made a quick exploration of the differences between the Matthean and Markan accounts and note that, aside from similar context and wording, there are basic differences in these two Gospels which warranted the study of the Markan account independent from Matthew. I opened the chapter, footnoting the wide variety of 
interpretations derived from these two main sources (Matthew and Mark), and proceeded to briefly overview some of the modern voices in the history of interpretation of the Markan statement on "divorce," the majority of which question the validity of the original question, "Is it lawful for a man to divorce his wife?" (Mark 10:2).

The majority of scholars who disavow the probability that the Pharisees would have posed such a question function under the rationale that the Jewish religious people knew the Mosaic mandate of Deut 24:1-4 and that their debates were not based on whether divorce was possible, but only as to the reasons when it should be granted. Other scholars sustain, within the Matthean context, that the "divorce" question was a Pharisaic plot to force Jesus to take sides, either with the Shammaites or with the Hillelites.

There are other scholars, mainly within the Catholic and fundamentalist Protestant traditions, who adhere to a more literalistic interpretation of the text in which Jesus purportedly forbids divorce by pointing to his appeal to God's original Edenic ideal (Mark 10:6-7) in which there is no divorce and no remarriage.

The "divorce" saying of Jesus in the two main Gospel accounts, Matthew and Mark, contains an important distinction which scholars have dubbed the "exception clause" ("except for sexual immorality," NKJV; “except for unchastity,” NRSV). While this exception is a mainstay in the Matthean account $(5: 32 ; 19: 9)$, its absence in the Gospel of Mark has been a cause for debate and perhaps the reason that Matthew became the principal source of interpretation in the history of the Christian Church.

While there are those who believe that Jesus may not have included this "exceptive clause" in his original teaching, there are those who find Matthew's inclusion justified since it plays well to his intended Jewish audience who supposedly, spurred by 
the Hillelites, had made it a practice to divorce their wives "for any reason." Some argue that if Paul, under inspiration, was free to make other exceptions to this teaching (1 Cor 7:8ff.), why not Matthew? Yet there are those who believe that the "clause" belongs to the original saying since, without it, Jesus' statement, "whoever divorces commits adultery," becomes nonsensical.

One very interesting argument placed the question of divorce "for the sake of the kingdom." The argument is based in Jesus' statement in Luke 18:29, "And he said to

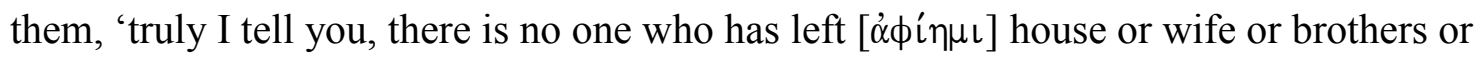
parents or children, for the sake of the kingdom of God."' And so it is argued that a response to God's kingdom may entail “divorcing” one's spouse or even refusing to marry if the new spouse may cause the other from entering the kingdom (Luke 14:20).

Then we came to the Jesus Seminar. By color coding the words of Jesus, the Seminar assigned red lettering to words Jesus most likely said; pink lettering to words ascribed to Jesus by those who followed him, yet not authentic; bold black lettering to words never spoken by Jesus; and gray lettering words not spoken by Jesus but that nevertheless may reflect some of his ideas. The Seminar did not assign any red lettering to the divorce saying of Jesus in either Matthew or Mark, thus discarding the authenticity of the saying altogether.

This literary survey in my introductory chapter is only representative of the debate that was dealt with in-depth in my exegesis chapter (5). The variety of interpretations brought to the fore a need for a contextual analysis of the saying of Jesus on divorce, especially as it relates to the Gospel of Mark, of which a majority of NT scholars consider to contain the most primitive saying of Jesus on the matter. 
The primary purpose of chapter 2 was to investigate the extent of a Gentile presence in northern Palestine that may warrant a Galilean setting for Mark's message. Mark 10:12 reads, "And if she divorces her husband and marries another, she commits adultery."

The standard comment in most Bible commentaries on Mark 10:12 goes something like this: "This statement reflects a Greco-Roman practice in which a woman could easily obtain a divorce ..." yet, no systematic study has been produced, other than isolated quotations, insisting that such statement could only make sense in a Roman setting and that such practices may have been foreign to Palestinian Jews. Mark 10:12, therefore, is said to have been added by Mark to make Jesus' teaching on divorce relevant to a Gentile Roman audience.

Scholars who defend this view point out Mark's numerous Latinisms, his translation of Aramaic terms, and his explanation of Jewish practices. This widely held assumption was borne out of an obscure statement by the early Church father, Papias, who places the writing of the Gospel in Rome, a statement strongly contradicted by a large number of scholars. Aside from the Roman setting, other settings have been timidly suggested, but gained little or no support—such places as Antioch of Syria and even an Egyptian origin.

Internal (biblical) and external (historical) records seem to contradict the above assumption. Studies within the past two or three decades have begun to defend the case for a Palestinian setting of the gospel. They have demonstrated that Mark's use of Latinisms, his translation of Aramaic terms, and his explanation of Jewish practices may well have been required right there in Palestine given the following: 
1. There was a large number of occupying Roman forces and their families living in Palestine.

2. Galilee was known as "Galilee of the Gentiles" (Matt 4:15) during the time of Jesus precisely because the majority of northern Palestinians were Gentiles and these were widely addressed by Jesus during his ministry there.

3. Jewish debates and the Pharisaic-Herodian plot against Jesus would be meaningless to people living in Rome.

4. Geographical details given by Mark, such as the naming of towns in and around Galilee, would be totally foreign to anyone not living in Palestine.

5. The legacy and influence of Greek culture, permeating especially the ruling classes, are undeniable realities of Palestinian life.

6. Galilee served as a main route for commerce between East and West.

7. Women, including Jewish women, could obtain a divorce within Palestine; this may prove that the gospel found its setting in the land where Jesus did most of his teaching.

The results of the structural analysis of chapter 4 in which the grammatical connectors support the unity between Mark 10:2 and 10:12 may prove that a foreign practice of a woman divorcing her husband indeed may have been what Jesus was addressing privately to his disciples concerning the house of Herod, thus placing the Gospel of Mark in a Palestinian setting (see my comments below).

Chapter 3 provided a background of Roman history on the question of marriage and divorce and how those practices may have affected Palestinian life through GrecoRoman enculturation, travel, commerce, and Roman occupation. I closed chapter 3 by 
analyzing some of the marriage-divorce conditions of Rome as the first century BCE came to a close. There were no marriage or divorce laws except for those among the rich and the ruling classes in the Roman Empire during the Republican era. If a married woman wanted to divorce, all she needed to do was write a letter stating that she no longer wished to remain in the relationship. For the poor and the slave, desertion or separation, by either the male or female, was the order of the day when ending a relationship.

In chapter 4, I was able to identify some key elements of the Markan "divorce" pericope which not only show its delimitations within the main structure, but also demonstrated clear connectors of continuity between the previous and subsequent units/sections. This analysis demonstrated that we are not dealing with a "cut and paste" literary unit, but rather, a self-contained one that embraces the thrust of the Markan Gospel. In the first section we embarked on the task of discovering the delimitation of the "divorce" pericope which involved identifying indicators of continuity and/or discontinuity. In the first major indicator we found that the unit contains explicit statements concerning:

1. Change in time

2. Change of venue, and

3. Change in subject matter.

A second major indicator has to do with the structural function of the "divorce" pericope in which the syntax, grammar, verbal parallelisms, and repeated literary patterns formed the framework of the unit. A third major indicator dealt with rhetorical devices in which a consistent repetition of vocabulary and phraseology, both at the beginning and at 
the end of the pericope, set the unit apart. A fourth key indicator dealt with some dualistic features that identified Mark's own personal writing style, rather than purported pieces "sewn" together here and there by a later editor. These involved:

1. Repetition of cognate verbs

2. Contrasting negative and positive

3. Repetition of antecedents

4. Repetition of motif.

Another major indicator of unity is that which ties the Markan pericope on "divorce" to the previous section/chapter by the repeated use of the anaphoric personal pronouns "he" or "him" starting in Mark 10:1. These personal pronouns find their identity in the personal noun "Jesus" twelve verses back in Mark 9:39, proving that the pericope belongs to a single literary unit.

The next major section of chapter 4 involved confirming the unity of the Markan pericope on divorce (10:1-12) by conducting a grammatical-syntactical analysis. Structure "A" showed clear grammatical and syntactical connectors between vv. 2 and 12 , tying the pericope together and showing that 10:12 is not a mere addendum to Jesus' teaching (see my comments below). The structural analysis was followed by a lexicalsyntactical analysis of the pericope which showed how certain lexical-syntactical nuances are crucial in the understanding of the Markan "divorce" teaching. These nuances considered phrase construction, lexical possibilities, MSS variances, consistency or inconsistency in translation, etc.

We then proceeded to study the crux word generally translated "to divorce" $(\dot{\alpha} \pi 0 \lambda \dot{v} \omega)$ in order have a picture as to how different translations have dealt with it. 
Depending on the version/translation or language (English, Spanish, Portuguese, French, or German) different meanings were given to $\alpha \pi 0 \lambda \nu$ v. Some of those meanings were cognate or synonymous words, while others clearly meant something other than divorce.

The most common inconsistent translation of $\alpha$ mo $\lambda \dot{u} \omega$ was found in Mark 10:2-4, "The Pharisees came and asked Him, 'Is it lawful for a man to divorce ( $\dot{\alpha} \pi 0 \lambda \hat{\sigma} \sigma \alpha \iota)$ his wife?' testing Him. And He answered and said to them, 'What did Moses command you?

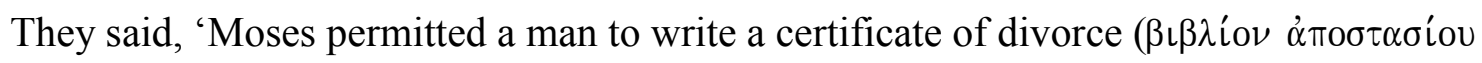
$\gamma \rho \alpha \dot{\alpha} \psi \alpha \iota)$, and to dismiss [to send out, to expel] ( $\alpha \pi 0 \lambda \hat{v} \sigma \alpha \iota)$ her."' Structural connectors showed that the most likely translations of $\dot{\alpha} \pi \circ \lambda \hat{\sigma} \sigma \alpha \iota)(10: 2,4)$ and $\dot{\alpha} \pi 0 \lambda \cup \dot{\sigma} \alpha \sigma \alpha(10: 12)$ are precisely "to expel," "to send away," "to dismiss," but not "to divorce." This meaning was made more specific in the next section by analyzing the contextual meaning of $\dot{\alpha} \pi 0 \lambda \dot{v} \omega$ and derivatives in both the LXX and the NT.

We did not find any indication that $\dot{\alpha} \pi \mathrm{o} \lambda \dot{\omega} \omega$ and derivatives may mean "to divorce" in either the LXX or the NT (aside from those instances in which translators

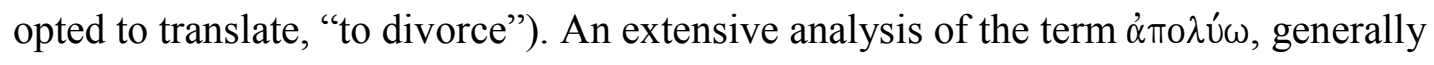
translated "to divorce," showed that historically $\dot{\alpha} \pi 0 \lambda u ́ \omega$ is not the term used for divorce in the Classical Greek of the century prior and subsequent to NT times (see the Appendix). That "to divorce" is not the inherent meaning of $\dot{\alpha} \pi 0 \lambda \hat{v} \sigma \alpha \iota$ can also be seen in Joseph's attempt to cover up for his future wife's "sexual indiscretions." "Planned to put

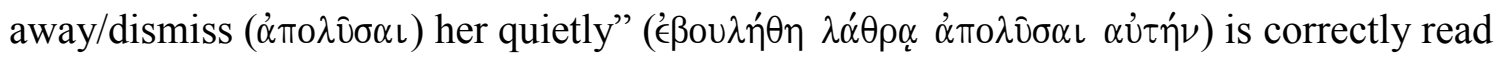
in most versions. "Had in mind to divorce her privately" (NIV), "decided to divorce her 
informally" (NJB), and "resolved to divorce her quietly" (ESV) are but a few versions which incorrectly ${ }^{1}$ translate $\dot{\alpha} \pi 0 \lambda \hat{\sigma} \sigma \alpha \iota$ "to divorce."

In the last section of chapter 4, I delved into the possible terms used for divorce in and around the NT period. We looked into biblical and non-biblical sources and discovered that while $\dot{\alpha} \pi 0 \lambda \hat{u} \omega$ is the term translated "to divorce" by most Bible versions in the Synoptics' "divorce" saying, most translators do not seem to be aware that during Roman and Byzantine periods $\chi \omega \rho i \zeta \omega$ and/or $\delta\llcorner\alpha \chi \omega \rho i \zeta \omega$ are the terms used to describe the process of divorce.

Linguists such as Pring, Moulton, and Milligan concur that $\delta\llcorner\alpha \chi \omega \rho i \zeta \omega$ is the term used for divorce by Greek-speaking cultures up to modern times. It is also the term used for divorce in Greek marriage contracts of the first four centuries CE. Staunch supporters of the "biblical teaching on divorce" such as Fitzmyer, who argues that $\dot{\alpha} \pi 0 \lambda \dot{\omega} \omega$ means "to divorce" in the Gospels, himself admits that $\chi \omega \rho^{\prime} \zeta \omega$ is the most common term for divorce used by the Greek writers of the classical and Hellenistic periods.

The contextual, structural, grammatical, and syntactical analyses point to the probability that the Markan Jesus was not being addressed by the Pharisees on the question of divorce proper, but rather the practice of desertion, abandonment, and in the case of the upper classes by those influenced by Greco-Roman culture, "high heeled" Jewish women who served their husbands with a letter of divorce, an act that became a scandal among religious Jews in Northern Palestine in regard to the house of Herod.

\footnotetext{
${ }^{1}$ See chapter 4 .
} 
In chapter 5, I closed my study by focusing on the biblical text of the Markan saying on "divorce:" I examined the geography and the circumstances in which Jesus made important statements that affected the region. Galilee and Galileans were the focus of Jesus' ministry, and those who heard him were affected positively or negatively when his messages hit home as it did the Herodian house.

Next I analyzed the role of the Pharisees in the context of the Markan narrative where they play a key role, along with the Herodians, in their constant attempt to entrap Jesus and perhaps carry him to the same fate as that of John the Baptist. The "lawfulness" of the "divorce" question (Mark 10:2) was one more attempt to entrap/test ( Jesus should he publicly make a statement that affected the Herodian house.

Sensing the "trap," the Markan Jesus appeals to Moses, implying that Moses' injunction in Deut 24:1 was not being followed. Moses was clear as to the divorce procedure. Deuteuronomy 24:1 reads, "And so he writes her a certificate of divorce, puts

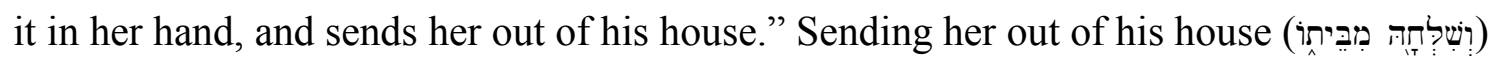
without the written declaration (ספּר כְרִיתוּת) was not divorce according to Moses. The written statement in the woman's hand upon being sent away from the husband's home would enable her to remarry. ${ }^{2}$ Both the UBS and the LXX contain the same grammatical

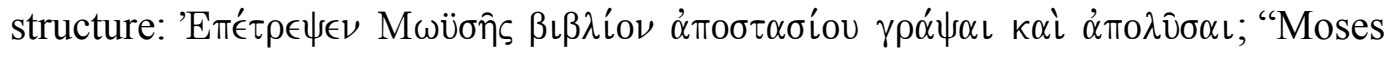
allowed [a man] to write her a letter of divorce and [then proceed] to send her away"

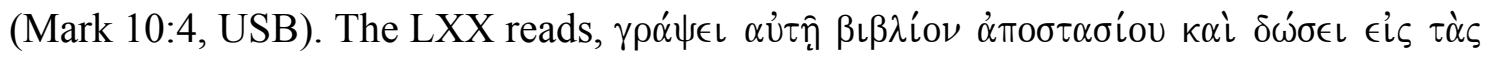

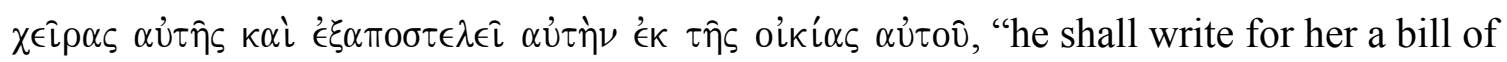
(m. Git. 9.3).

${ }^{2}$ The divorce document is said to have contained the words "Lo, thou art free to marry any man" 
divorcement, and give it into her hands, and he shall send her away out of his house" (Deut 24:1, Brenton's translation, emphasis supplied). In “write and expel/send away/dismiss," the consecutive conjunction "and" plays a prominent role in establishing procedure on matters of divorce.

Such procedure is: "Write her a letter of divorce and (then) send her away/expel/dismiss her" (Mark 10:4, emphasis supplied). This lack of procedure, which the Tetrarch's new wife and Herod himself had not followed in divorcing their previous spouses, appears to be the implication behind the Pharisaic "test" question (Mark 10:2). The Pharisees, along with the Herodians, attempt one more time to implicate Jesus in a public manner. ${ }^{3}$

The historical-contextual reconstruction of this interpretation is further elucidated in the structural analysis of chapter 4 . In connector $\mathbf{A}^{\mathbf{2}} \mathbf{a}$ we find the original Pharisaic

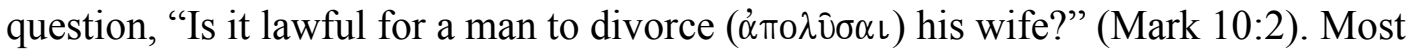
English translations use "to divorce" here and in the next two instances that derivatives of $\dot{\alpha} \pi 0 \lambda \cup ́ \omega$ appear in the pericope (Mark 10:11,12), except in 10:4 where most Bible versions translate $\dot{\alpha} \pi 0 \lambda \hat{v} \sigma \alpha \iota$ "to dismiss, to put her away, or send her away" preceded by

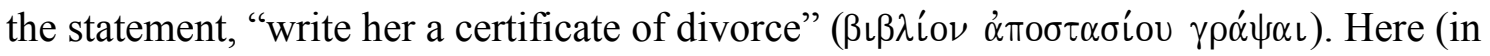
Mark 10:4) the Pharisees paraphrase Deut 24:1.

In connector $\mathbf{A}^{\mathbf{2}} \mathbf{b}$, following the grammatical structure of the BHS, the Markan paraphrase implies that $\dot{\alpha} \pi 0 \lambda \hat{v 0} \sigma \iota$ cannot mean divorce in Mark 10:4, but only the act of

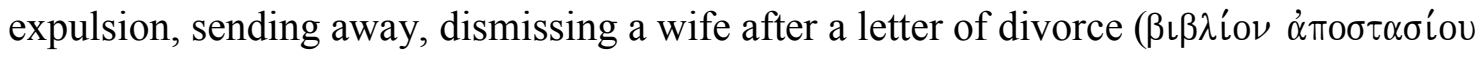

\footnotetext{
${ }^{3}$ See Josephus Antiquities 18.5.4; cf. 15.7.10.
} 
$\gamma \rho \alpha ́ \psi \alpha \alpha$ ) has been placed in her hand. "Is it lawful for a man to expel/dismiss/send away his wife" is what appears to be behind the Pharisaic question of connector $\mathbf{A}^{\mathbf{2}} \mathbf{a}$, which also can be seen in connectors $\mathbf{A}^{2} \mathbf{c}$ and $\mathbf{A}^{2} \mathbf{d}$ in the use of $\dot{\alpha} \pi 0 \lambda \dot{\sigma} \sigma \eta$ and $\dot{\alpha} \pi 0 \lambda \dot{v} \sigma \alpha \sigma \alpha$, respectively (Mark 10:11-12).

Jesus clarifies the question in private to his disciples that the Mosaic procedure had not been followed by the house of Herod: "He said to them, 'whoever dismisses/sends away/expels ( $\dot{\alpha} \pi 0 \lambda \dot{\sigma} \sigma \eta)$ his wife and [she] marries another commits adultery against her [rather, causes her to commit adultery] ${ }^{4}$ and if she dismisses/sends away/expels/leaves ( $\dot{\alpha} \pi 0 \lambda \cup ́ \sigma \alpha \sigma \alpha)$ her husband and marries another, she commits adultery" (Mark 10:11-12), ${ }^{5}$ and rightly so, for she is not (Herodias) or has not been (Naphaelis) properly divorced.

The fact that Jesus spoke this in a private setting to his disciples makes it improbable that Jesus wanted to address the general crowd on the matter. Such a public statement would have landed him in the Herodian "trap" that the Pharisees set out with the question, "Is it lawful for a man to leave his wife?"

Considering that Jesus' private comment to his disciples (Mark 10:10-12) reflected a Gentile practice of the house of Herod in Palestine, in which not only the

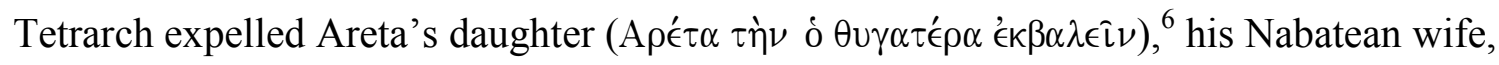
but mainly the Jewish scandal in which Herodias wrote a letter of divorce to her husband,

${ }^{4}$ Most likely the meaning, since in Judaism when a man takes a free woman as a second wife, neither he nor she is considered to commit adultery. See Banks, Jesus and the Law, 156.

${ }^{5}$ As Hauck puts it, "[In Judaism] unconditional fidelity is demanded only of the woman who in

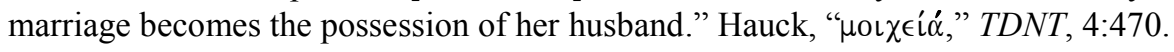

${ }^{6}$ See Josephus Antiquities 18.5.1. 
Philip, ${ }^{7}$ in order to marry his brother, the Tetrarch (Mark 10:12) ${ }^{8}$ The Markan statement, "Then in the house the disciples asked him again about this matter. He said to them, 'Whoever divorces his wife and marries another commits adultery against her; and if she divorces her husband and marries another, she commits adultery"” (Mark 10:10-12), makes perfect sense bringing the "test" question into full light concerning the contextual meaning of $\dot{\alpha} \pi \mathrm{o} \lambda \hat{v} \sigma \alpha \mathrm{L}$.

If the Matthean logion, as indicated by a large number of scholars, concerns Jewish sectarian debates, vis-à-vis, Shammai versus Hillel, then Instone-Brewer, in his assessment of Gundry, ${ }^{9}$ is right when he notes that "the Shammaites probably regarded the writing of the divorce certificate as the only necessary act in divorce, while the Hillelites said that three acts were necessary: Writing, giving, sending away." ${ }^{10}$ This, then, implies the precise procedure in which Moses stated it was not being followed in the Herodian house thus making room for the Pharisees to approach Jesus with the "test" question.

\section{Concluding Remarks}

I acknowledge that this study is only one more study in the long line of interpretations of a divorce text. I felt, however, that a new look at the Markan pericope

7"“ $[.$. for] this was not according to the Jewish laws; for with us it is lawful for a husband to do so; but a wife, if she departs from her husband, cannot of herself be married to another, unless her former husband put her away.” Josephus Antiquities 15.7.10.

${ }^{8}$ Cf. ibid., 18.5.4.

${ }^{9}$ See Robert H. Gundry, Matthew: A Commentary on His Handbook for a Mixed Church under Persecution (Grand Rapids, MI: Eerdmans, 1994), 379.

${ }^{10}$ Instone-Brewer, “Jesus' Teaching," $142 \mathrm{n} 17$. 
was needed in that no in-depth study had been done regarding what the Markan Jesus has to say on the question of divorce.

I found it imperative to highlight the fact that in the traditional interpretation (in its theological application) the Church has not looked at the Markan text in conjunction with its Matthean counterpart. Additionally, historically speaking, the Church has not looked at Mark in both its immediate (micro structure) and broad (macro structure) contexts in which he places the Jesus teaching on "divorce." My concern to review a well-covered subject resided in the unsatisfactory way in which the Church (in general) appears to put words in Jesus' mouth out of his kerygmatic context. It has been my concern how the Jesus of the Gospels has been made to reflect denominational theological leanings.

The Christian Church has generally overlooked the fact that the reason there are four Gospels is because there are four different audiences with four different needs. The Markan audience was able to understand the Markan saying on "divorce" because they lived in the environment; they heard of the debates, they saw the confrontations between Jesus and the Pharisees; they were affected by the actions in the royal palace.

If there is any strength in this study, it is because it has visited the context and the language in which the "divorce" teaching is couched and has found its traditional interpretations wanting. The attention to structure, language, syntax, grammar, etc., needs to be brought to its practical level: the Church, where discipline is applied to those found in the grip of divorce.

The results of this study continue to open areas yet to be explored; continue to challenge us to do more exegetical studies that are faithful to text and context of the 
gospel teaching on this and other subjects, as well as what Paul said, and certainly, the rich language in which the subject is treated in the OT. As far as the OT is concerned, more attention needs to be paid to the terms we generally use to describe divorce, especially in those texts where divorce had not yet been legislated, vis-à-vis, biblical history prior to Deut 24.

If there is anything exegesis can teach us is that the ancient text must be studied on its own terms. There is no greater intellectual vacuum when the biblical interpreter casts aside all that the biblical text meant in the past, plucking it out of its historical context, and immediately constructing a church discipline, manual, or a canon law of a modern church parlance.

The serious Bible student recognizes that there is a dialogue between what the text meant for the original hearers and what it means today; and since the study of the Bible must be done in a dialogue between the past against the present, it is necessary to understand the cultural values and social practices of the time; otherwise, meaning will fail unless the biblical interpreter assumes that a cultural worldview of today cannot be imposed upon a cultural worldview of the period in which a particular Bible passage or book was written. Failing at this differentiation usually ends up creating theological monstrosities. And this is my fear.

We need to learn to curb our tendencies to project back twenty-first-century views into primitive and illiterate cultures of three or four millennia ago. Although his remarks were directed towards the interpretation of history, rather than Scripture, Millar's words 
warn us of the danger of "contaminating the past with the present."11 There is much, of course, to be said against the tendency to distort the biblical text with heavy-handed moralizing undertaken from an assumed vantage point of contemporary theological superiority, but suffice it to say that the interpretation of Scripture is still open for the serious taker. xii.

${ }^{11}$ Fergus Millar, The Emperor in the Roman World (Ithaca, NY: Cornell University Press, 1977), 


\section{APPENDIX}

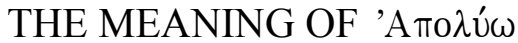

Since the Greek term $\dot{\alpha} \pi 0 \lambda \dot{u} \omega$ has been given different meanings in the so-called “divorce passages" of the Synoptic Gospels by the different Bible translations ${ }^{12}$, the purpose of this appendix is to study how this Greek term was used in the JudeoHellenistic and classical Greek literature. The $T L G$ shows that the Judeo-Hellenistic and the classical Greek literature of the first century BCE contain close to three-hundred occurrences of derivatives of $\dot{\alpha} \pi \circ \lambda u^{u} \omega$; while the extra-Biblical Greek literature of the first century CE contains it more than four hundred times.

At the same time, the Patristic, the Apocryphal, the semi-Christian, and pagan literature of the second century CE uses the derivatives of $\dot{\alpha} \pi 0 \lambda \dot{\omega} \omega$ over eight-hundred times. Following is an exhaustive compendium of the meaning of $\alpha \pi 0 \lambda u^{\omega} \omega$ and its derivatives as it has been rendered in the English translations in works of the JewishHellenistic, Christian, and pagan Roman historical, medical, mathematical, and religious writings two centuries immediately preceding and the decades immediately following the NT period. It should be noted the a large number of derivatives of $\dot{\alpha} \pi 0 \lambda \dot{u} \omega$, mostly from the classical Greek, are not found in the NT. ${ }^{13}$

\footnotetext{
${ }^{12}$ See tables $2-7$ in chapter 4.

${ }^{13}$ No available English translations were found for $\alpha \pi \circ \lambda \hat{u} \omega$ and derivatives in these lesser known works: Chionis Epistulae (two entries), Flavius Arrianus (two), Andromachus (one), Pseudo Apollodorus (two), Heron (three), Rufus (three), Soranus (six), Gaius Musonius Rufus (five), Lucius Annaeus (two),
} 


\section{The First Century BCE}

\section{The Pseudepigrapha ${ }^{14}$}

The entries for the derivatives of $\alpha$ mo $\lambda u$ u in the Judeo-Hellenistic Pseudepigraphical writings of the Second Temple period contain the following:

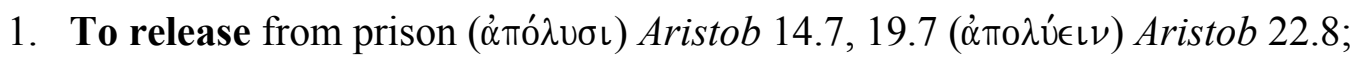

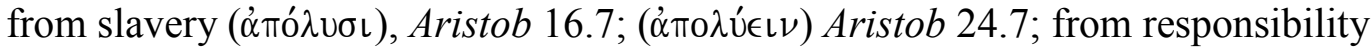

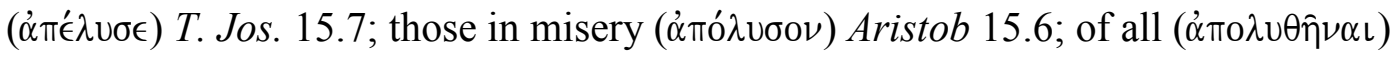

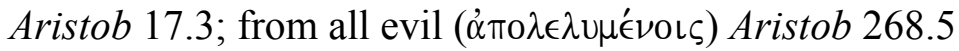

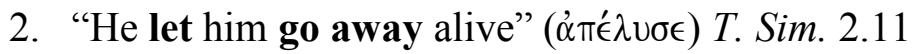

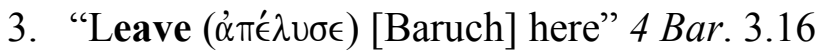

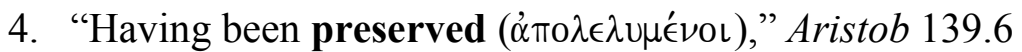

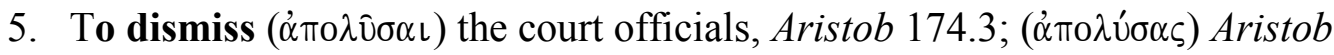

175.7

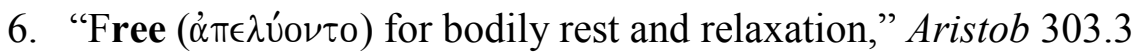

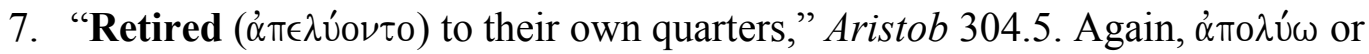
any of its derivatives is a term used for some sort of separation from something or someone. Divorce, proper, in the Pseudepigrapha, is generally rendered from the derivatives of $(\delta\llcorner\alpha) \chi \omega \rho i \zeta \omega$.

Dioscorides Pedannus (three), Ammonius (four), Erotianus (three), Thessalus (two), Ostanes Magus (one), Apollonius (four), Cebes (one), Pamphila (one), Cyranides (eight), Marcus Antonius Polemon (one), Harpocration (four), Herennius Philo (once), Hermogenes (five), Dorotheus Abbas (one), Heliodorus (one), Aristobtonicus (four), Didymus (one), Dorotheus Astrologus (four), Memnon (one), Nicolaus (five).

${ }^{14}$ The English meanings have been gleaned from James H. Charlesworth, ed., The Old Testament Pseudepigrapha (Garden City, NJ: Doubleday, 1983-1985), "Aristobulus," 2:837-842; "The Testament of Simeon," 1:785; "4 Baruch," 2:419. 


\section{Dionysius of Halicarnassus: $60 \mathrm{BCE}$ to $7 \mathrm{CE}^{15}$}

Dionysius contains almost two hundred entries of derivatives of $\dot{\alpha} \pi 0 \lambda \cup ́ \omega$. Here are the results from the largest possible selection chosen from each of his treatises. (1) to clear/to absolve/to acquit/to set free as from a charge, an accusation, an obligation

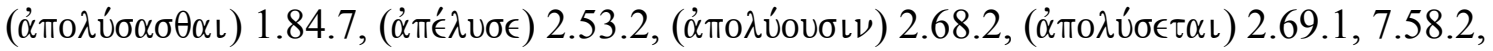

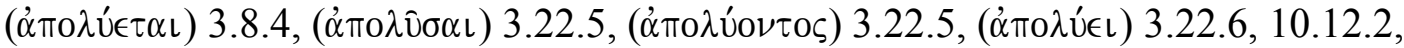

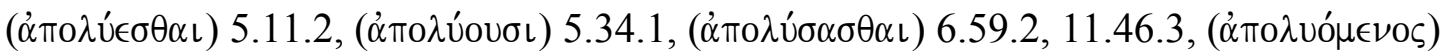

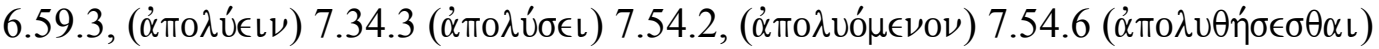

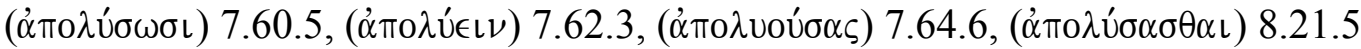

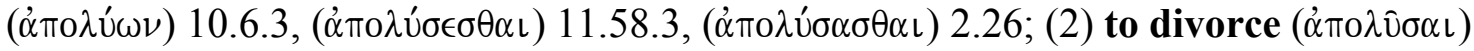

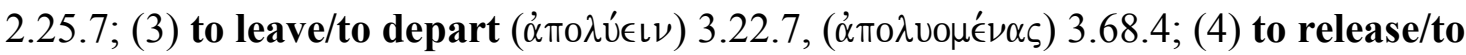
discharge/to let go from a duty, a responsibility, a post (ஷ்

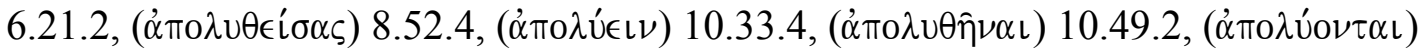

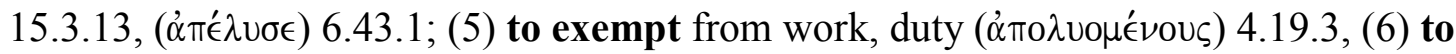
dismiss/to send away a person or an assembly after a meeting or fulfilling a duty

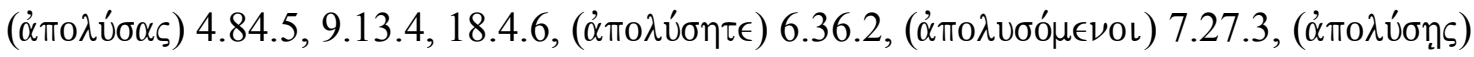

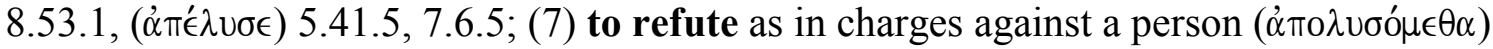

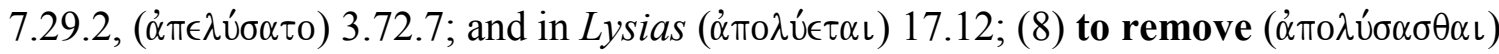

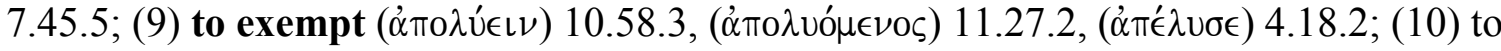
escape as from death, prison ( $\dot{\alpha} \pi 0 \lambda \dot{v} \in \tau \alpha \iota) 11.46 .5$; (11) to demolish an argument, in

\footnotetext{
${ }^{15}$ Dionysius Antiquities.
} 


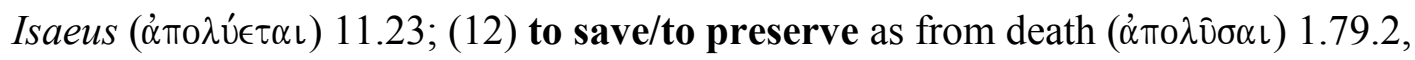
(

The great majority of occurrences fall under the first category, "to clear, to absolve, to acquit, to set free." The categories that came in second, with an approximately equal number of entries are: "to dismiss or discharge, and to release or send away." From the writings of Dionysius, however, the overwhelming evidence shows that $\dot{\alpha} \pi \circ \lambda \dot{v} \omega$ and derivatives do not mean divorce or are intended to be rendered in that context.

There was one entry where "divorce" is rendered in the translation. Interestingly enough, the grammatical form is identical to that which is found in the Gospels: A $\pi \circ \lambda \hat{\sigma} \sigma \alpha L$. As used by Dionysius, is in the context in which he sighs that "no marriage

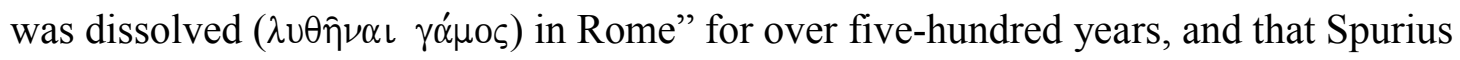
Carvilius was the first to divorce ( $\dot{\alpha} \pi \mathrm{\lambda} \lambda \hat{\mathrm{v} \sigma \alpha \iota)}$ ) his wife. ${ }^{16}$

According to Dionysius, this happened in a world where "the husbands ruled their wives as necessary and inseparable possessions." ${ }^{17}$ The context of Carvilius' account, however, is one where the wife is sent away from his house in a world where "no marriage was [ever] dissolved." This lone instance where $\dot{\alpha} \pi 0 \lambda \hat{v} \sigma \alpha \iota$ is translated "to divorce" may not prove that it is referring to a legal divorce procedure during this period. $^{18}$

\footnotetext{
${ }^{16}$ Dionysius Antiquities 2.25.7. Emphasis supplied.

${ }^{17}$ Dionysius Antiquities 2.25.4

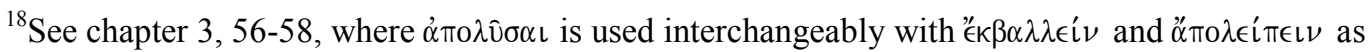
either "to divorce" or "to leave," apparently as the translators saw fit to translate.
} 


\section{Diodorus of Sicily ${ }^{19}$}

Diodorus contains more than one-hundred entries to $\alpha \dot{\pi} \pi \nu \lambda \dot{v} \omega$ and cognate words dispersed throughout his Bibliotheca Historica. The largest selection possible will be analyzed from the sixty books he wrote, with special attention given to derivatives of $\dot{\alpha} \pi 0 \lambda u^{\prime} \omega$ as found in the NT. (1) to clear/to absolve/to acquit/to free/to dismiss/to dispel of an accusation, an obligation, a charge, from prison, from fear, anxiety, from captivity $\left(\dot{\alpha} \pi^{\prime} \lambda v \sigma \epsilon\right)$ 1.54.2, 2.28.5, 9.11.1, 12.55.10, 15.11.1, 15.92.5, 17.4.9, 21.14.2, 29.31.1,

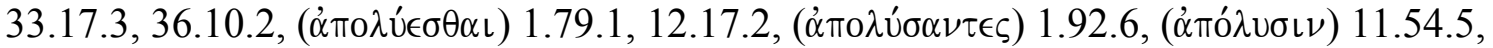

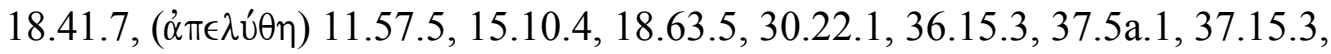

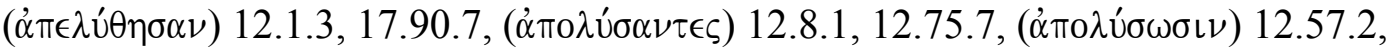
$(\dot{\alpha} \pi 0 \lambda \hat{\sigma} \sigma \alpha \iota) 13.42 .1,16.52 .3,16.52 .6,18.66 .3,(\dot{\alpha} \pi 0 \lambda \hat{v} \sigma \alpha \varsigma) 13.101 .5,22.13 .1,\left(\dot{\alpha} \pi 0 \lambda \nu \theta^{\prime} \epsilon^{\prime} \tau \in \varsigma\right)$

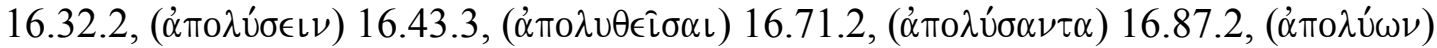

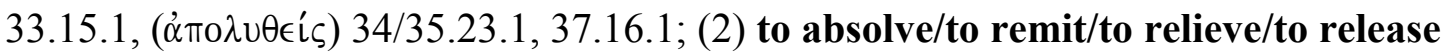

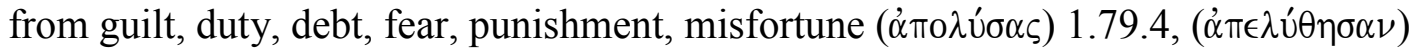

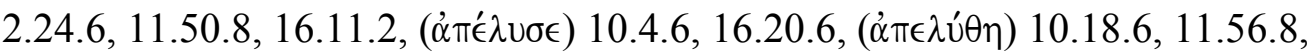

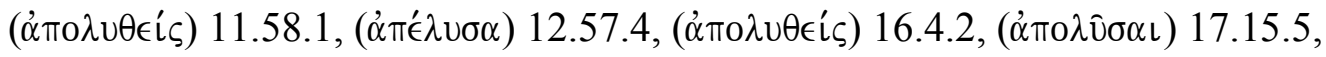

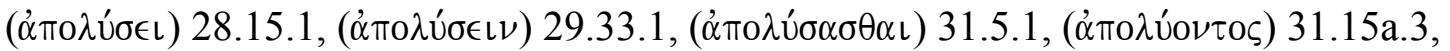

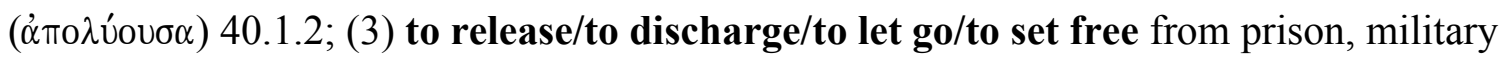

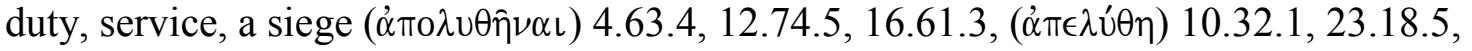

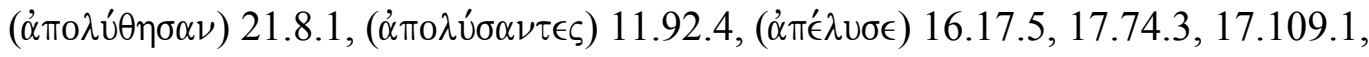

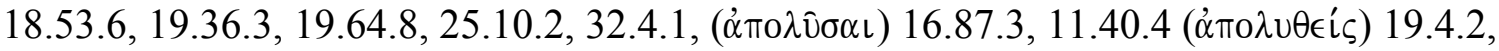

\footnotetext{
${ }^{19}$ Charles Henry Oldfather, trans., Siculus Diodorus, LCL (New York: Putnam, 1933-1967).
} 


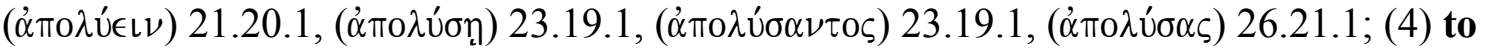
get rid of $(\dot{\alpha} \pi 0 \lambda \nu \theta \hat{\eta} \nu \alpha \iota) 10.18 .3,(\dot{\alpha} \pi 0 \lambda \dot{v} \sigma \omega \sigma \iota) 11.40 .4, ;$ (5) to dismiss/to send away/send back/to dispatch an envoy, a crowd, an emissary ( $\left.\dot{\alpha} \pi \epsilon^{\prime} \lambda \nu \sigma \epsilon\right)$ 2.3.2, 11.37.5, 13.96.1,

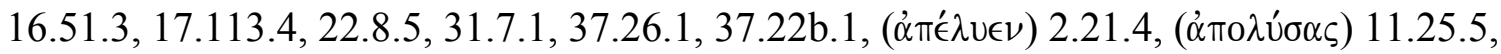

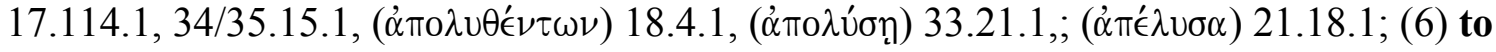

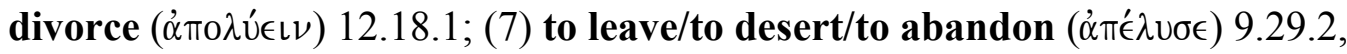

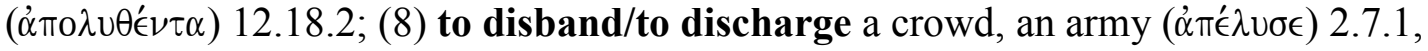

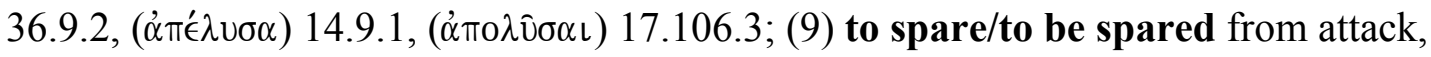

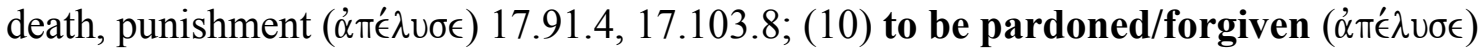
$17.96 .5,17.102 .7 ;$ (11) to bring to a close a fight, dispute $(\dot{\alpha} \pi \in \lambda \dot{U} \theta \eta) 29.10 .1 ;(12)$ to be

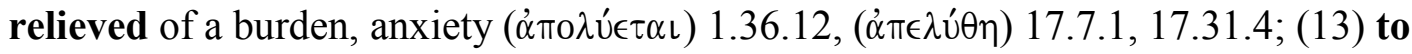
remit a debt, a penalty $(\dot{\alpha} \pi 0 \lambda \cup ́ \sigma \in \iota) 1.54 .2$.

Of the over one-hundred entries that were analyzed, Diodorus produced only one entry where a derivative of $\dot{\alpha} \pi 0 \lambda u ́ \omega$ was translated "to divorce;" the present infinitive $\dot{\alpha} \pi \circ \lambda \cup \in \in L \nu$ (12.18.1). Diodorus also contains twelve instances in which the derivatives of of $\dot{\alpha} \pi \circ \lambda \dot{v} \omega$ parallel the terms used in the "divorce" passages of the NT: $\dot{\alpha} \pi 0 \lambda \hat{v} \sigma \alpha \iota$ (nine times), translated: (1) to release from detention/prison (11.40.4, 16.87.3); (2) to dismiss charges $(13.42 .1,16.52 .3,16.52 .6,17.15 .5,18.66 .3)$; (3) to disband/to discharge

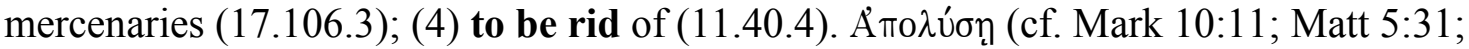
19:9), twice: (1) to release from captivity (23.19.1); (2) to send away a crowd (33.21.1). $\AA ̊ \pi 0 \lambda \cup ́ \omega \nu$ (cf. Matt 5:32), once: to set captives free (33.15.1).

The overwhelming number of times may be found in the first category above: "to absolve from an accusation, to acquit of charges, to free from prison, to dismiss a charge, 
to dispel fear, anxiety," etc. The other categories are closely related. It is quite interesting to see the variegated meanings the translators of Diodorus chose to give the term $\dot{\alpha} \pi 0 \lambda \dot{v} \omega$ and derivatives. As to what may have been the word for divorce in Diodorus and his time?, is hard to tell. The search for the meaning of derivatives of $\beta \dot{\alpha} \lambda \lambda \omega \omega$, ${ }^{\epsilon} \kappa \beta \dot{\alpha} \lambda \lambda \omega$, ${ }^{\xi} \xi \alpha \pi \dot{\epsilon} \sigma \tau \epsilon \lambda \lambda \omega,(\delta\llcorner\alpha) \chi \omega \rho \hat{\zeta} \zeta \omega$; other possible translations for divorce, produced no results, perhaps due to the fact that there may not have been any legal divorces taking place during this period.

\section{Late First Century BCE to Mid First Century CE}

\section{Philo-Judaeus of Alexandria, $20 \mathrm{BCE}$ to ca. $50 \mathrm{CE}^{20}$}

The works of Philo contain only seven derivative words from $\dot{\alpha} \pi \circ \lambda u ́ \omega$, none of

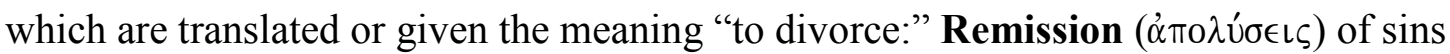
(Spec. Laws 1:215); twice in a commentary on Gen 15:2, "I go childless" (’் Heir 2.3; 34.1); "[to] the soul who stands on the verge of condemnation" ( $\dot{\alpha} \pi{ }^{\prime} \lambda v \sigma L$, Names 229.1); "[the Jewish people being] separated ( $\left.\dot{\alpha} \pi \circ \lambda v_{0} \nu \tau \tau \alpha \iota\right)$ from the law and from the temple" (Hypothetica 196.7); "many corpses from evil men were taken away

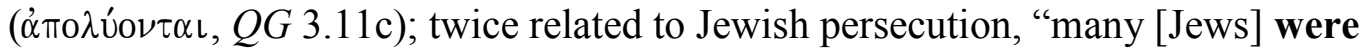

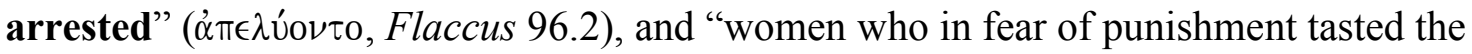

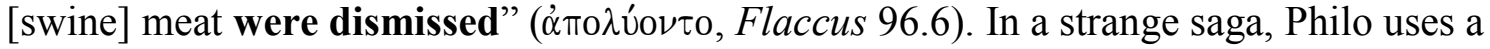
term that both Colson (LCL) and Yonge translate "to divorce",21: $\delta \iota \alpha \zeta \epsilon u \xi \xi \varsigma$. This term is

\footnotetext{
${ }^{20}$ Philo Philo (trans. Colson and Whitaker, LCL, 1968).

${ }^{21}$ Special Laws 3.80, in Philo Philo 4:79 and in Philo Works of Philo (trans. Yonge, 1997), 602, translate $\alpha \dot{\pi} \alpha \lambda \lambda \alpha \gamma \eta$ ' "to separate," which appears in the same paragraph.
} 
not generally known to mean "to divorce." 22 The $T L G$ produced no other instance in which $\delta\llcorner\alpha \zeta \epsilon \cup \xi \iota \varsigma$ is ever translated "to divorce" by the translators of the Judeo-Hellenistic writers.

\section{Strabo the Geographer, ca. $63 \mathrm{BCE}$ to ca. $21 \mathrm{CE}^{23}$}

Strabo contains thirteen entries for $\dot{\alpha} \pi 0 \lambda \hat{u} \omega$ and derivatives.

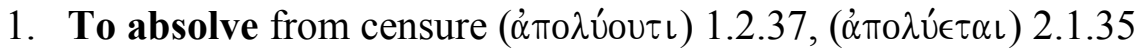

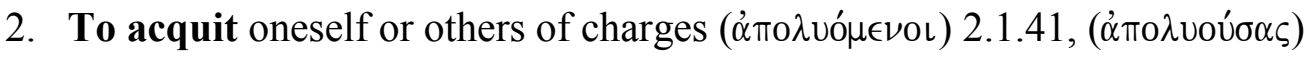

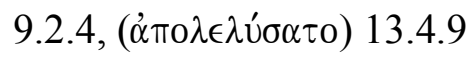

3. To release or to become lose $(\dot{\alpha} \pi \circ \lambda \nu \circ \mu \epsilon \in \omega \omega \nu) 4.6 .6$

4. Objection ( $\dot{\alpha} \pi 0 \lambda \dot{v} \in \tau \alpha \iota)$ 12.3.22

5. To take $(\dot{\alpha} \pi 0 \lambda v \theta \epsilon \hat{\imath} \sigma \alpha \nu) 14.1 .20$

6. To send someone to rescue another person ( $\alpha \pi \circ \lambda \hat{v} \sigma \alpha \iota) 14.6 .6$

7. To release from captivity $\left(\dot{\alpha} \pi \pi^{\prime} \lambda \nu \sigma \epsilon\right) 7.3 .8$

8. To send away [foreigners] to their homeland ( $\left.\dot{\alpha} \pi^{\prime} \dot{\lambda} \nu \sigma \epsilon\right) 11.14 .15,13.1 .52$

9. To atone ( $\dot{\alpha} \pi \in \lambda \dot{u} \in \tau 0)$ 14.2.24.

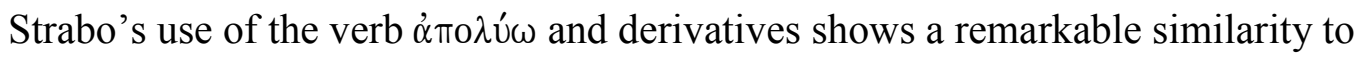
the uses as those of his contemporaries. No other terms for divorce were found in Strabo. It is quite enlightening, in view of the above analysis, to discover that the derivatives of $\dot{\alpha} \pi 0 \lambda u^{\prime} \omega$ in the Greek writings of the pre-New Testament period are rarely connected to

\footnotetext{
${ }^{22}$ Literally, "to untie or unbind." See Peder Børgen, Kåre Fuglseth, and Roald Skarsten, The Philo Index: A Complete Greek Word Index to the Writings of Philo of Alexandria (Grand Rapids, MI: Eerdmans, 2000), 117; cf. BDAG for related terms: $\delta \iota \alpha \zeta \omega \nu \nu \nu \mu \iota, 182$, and $\dot{\alpha} \pi \alpha \lambda \lambda \alpha \dot{\sigma} \sigma \omega, 80$.

${ }^{23}$ Strabo, Strabo.
} 
the concept of divorce. One is left to wonders whether the absence of a specific word for divorce during this period may be due to its non-institutionalization as we come to the end of the Roman Republic. ${ }^{24}$

\section{Plutarch, ca. 50 BCE to $14 \mathrm{CE}^{25}$}

The $T L G$ identified almost one hundred entries of $\alpha$ mo $\lambda \dot{u} \omega$ and derivatives in Plutarch's writings. From Plutarch's Lives the following entries were garnered:

1. To remove objects $(\dot{\alpha} \pi \epsilon ́ \lambda \cup \sigma \epsilon)$ Poplicola 10.5 .3

2. To turn lose $\left(\dot{\alpha} \pi 0 \lambda \epsilon^{\prime} \lambda \nu \sigma \epsilon\right)$ farm animals, Marcus Cato 5.3.3

3. To send ( $\left.\dot{\alpha} \pi^{\prime} \lambda \nu \sigma \epsilon\right)$ an envoy, messenger, representative, Alexander 42.3.3;

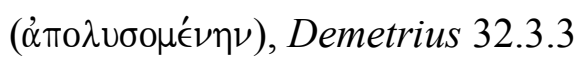

4. To dismiss ( $\left.\dot{\alpha} \pi \pi^{\prime} \lambda \cup \sigma \epsilon\right)$ honorably for a service rendered, Alexander 71.5.4

5. To release, to set free, to dismiss $(\dot{\alpha} \pi \in \lambda u ́ \theta \eta)$ from captivity, prison (sometimes

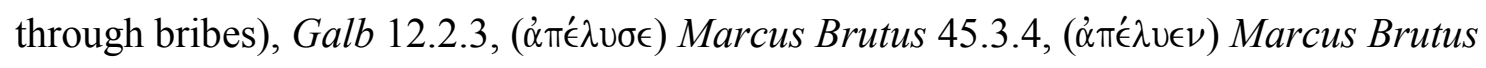

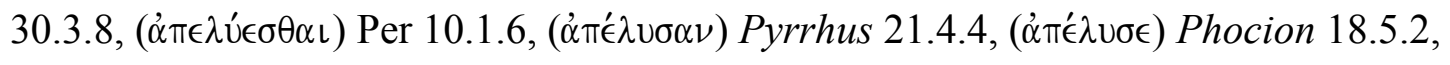
Demetrius 27.6.7, (ஷ்

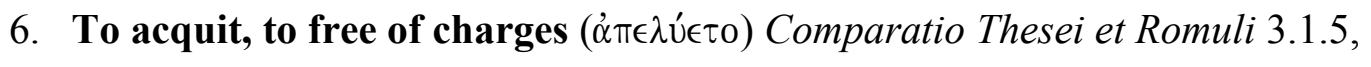

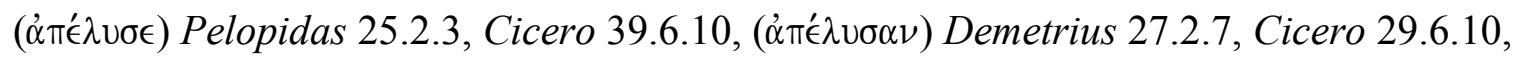

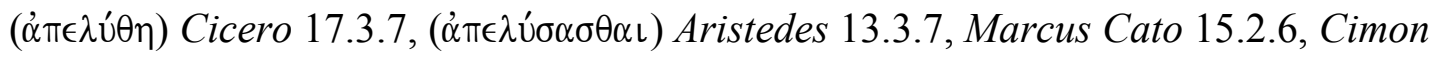

\footnotetext{
${ }^{24}$ For an overview of Greco-Roman law of divorce as the NT period approaches, see my chapter three.

${ }^{25}$ Plutarch, Moralia; Plutarch, Lives.
} 
17.4.10, Lys 28.4.6, (ஷ்

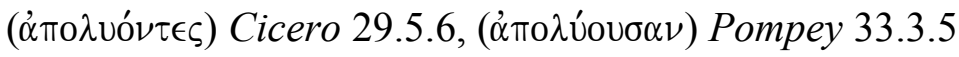

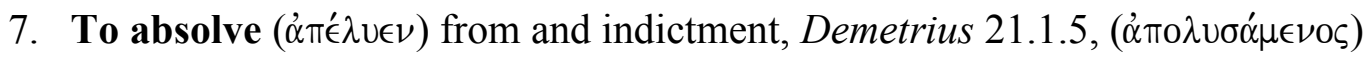
Crassus 1.2.9, Marcus Cato 16.6.7

8. To be pardoned ( $\left.\alpha^{\prime} \epsilon^{\prime} \lambda v \sigma \epsilon\right)$, Brut 11.1.2

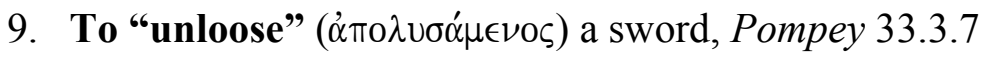

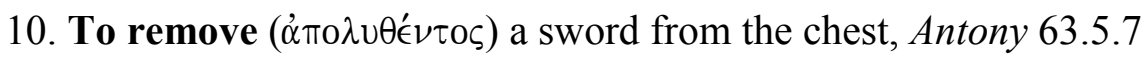

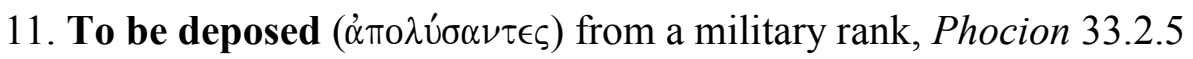

12. To dissipate, to make suspicions or charges naught ( $\left.\alpha^{\pi} \in \dot{\epsilon} \lambda \cup \sigma \epsilon\right)$, Antony

73.3 .1

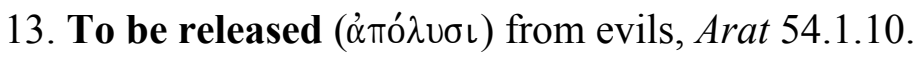

From Plutarch's Moralia the following results were obtained:

1. To release, to set free, to let go from prison, captivity or detention (avpe, lusan), Aetia Romana et Graeca (The Roman and Greek Questions) 283.F.7, ( $\left.\boldsymbol{\alpha}^{\prime} \in \dot{\lambda} \lambda \cup \sigma \epsilon\right)$ Regum et imperatorum apophthegmata (Sayings of Kings and Emperors) 176.B.1, 181.B.11, 207.F.12, Vitae decem oratorum (Lives of the Ten Orators) 84.B6,

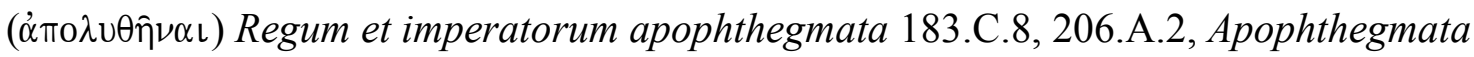
Laconica 236.A.6

2. To gain release ( $\dot{\alpha} \pi 0 \lambda \nu o ́ \mu \in \nu \circ \nu)$ from service or duty, Apophthegmata Laconica ( Sayings of Spartans) 209.B.10, (ஷ்

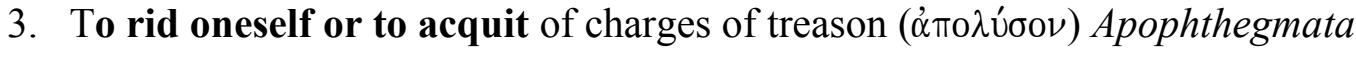

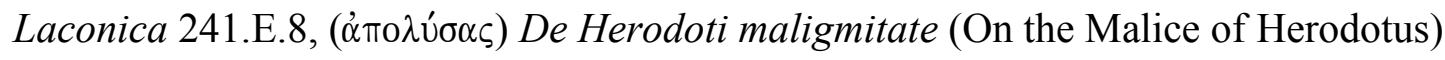




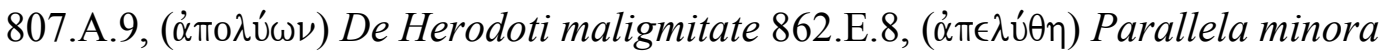
(Greek and Roman Parallel Stories) 309.D.13, Vitae decem oratorum 836.D.6

4. To release $(\dot{\alpha} \pi 0 \lambda \hat{v} \sigma \alpha \iota)$ from an oath or constraints, Aetia Romana et Graeca 287.D.11, (ஷ் $\left.\pi^{\prime} \lambda \cup \sigma \epsilon\right)$ De Stoicorum repugnantiis (On Stoic Self Contradictions) 104.B.7

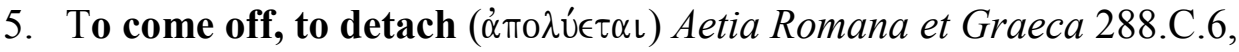

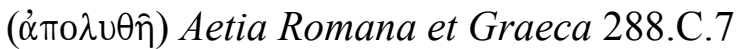

6. To send away free ( $\dot{\alpha} \pi 0 ́ \lambda v \sigma \iota)$, Aetia Romana et Graeca 300.A.8

7. To set free, to release $(\dot{\alpha} \pi 0 \lambda \nu \delta \in \hat{\epsilon} \sigma \alpha \iota)$ the soul, to migrate to an invisible place

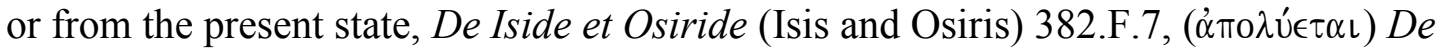

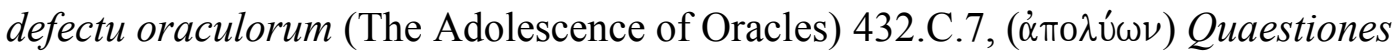
convivales (Table Talk) 716.B.10

8. Not to remain confined to (ג் $\pi 0 \lambda$ v́tous), De defectu oraculorum 426.B.6

9. To clear, to free $(\dot{\alpha} \pi \mathrm{0} \lambda \dot{v} \in \tau \alpha \iota)$ oneself of suspicion or accusation, De Defectu

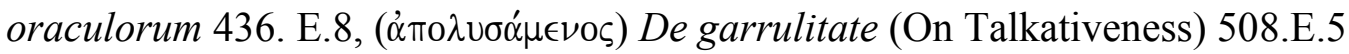

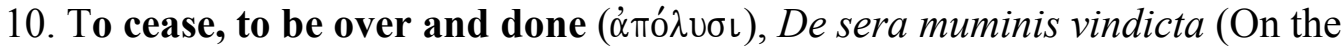
Delays of Divine Vengeance) 557.C.10

11. To be exempted of charges ( $\dot{\alpha} \pi \mathrm{o} \lambda \dot{\omega} \omega)$ Quaestiones convivales 714.E.6, 704.F.2

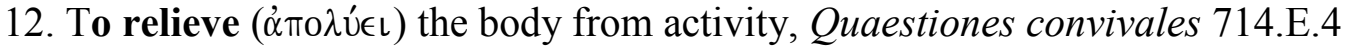
13. Deliverance ( $\dot{\alpha} \pi \circ \lambda \cup \circ \mu \epsilon \in \nu \eta \nu)$ from sense-perception, from "bruises on the

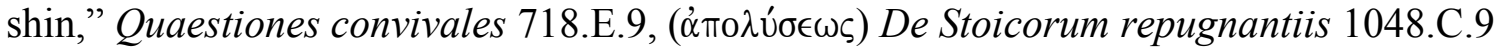

14. To send one person away $(\dot{\alpha} \pi \circ \lambda \hat{v} \sigma \alpha \mathrm{L}$, when three people came to hear Leochares speak), Vitae decem oratorum 838.E.2 
15. To leave $(\dot{\alpha} \pi \mathrm{0} \lambda \hat{v \sigma \alpha \iota)}$ vice unchecked, De Stoicorum repugnantiis 1050.C.1

16. To liberate (’ं $\left.\pi^{\prime} \dot{\lambda} \nu \sigma \epsilon\right)$ a city, Regum et imperatorum apophthegmata 203.D.10

17. To be absolved ( $\dot{\alpha} \pi \in \lambda \dot{\theta} \theta \eta)$ from a guilty verdict, Parallela minora 315.B.7.

From the numerous entries analyzed in Plutarch's works, most of the translations could be said to be quasi synonymous; yet not in one instance was $\dot{\alpha} \pi 0 \lambda \dot{v} \omega$ or any of its derivatives appear connected with the concept of divorce. There were eight entries with cognate words as those found in the NT, none meant divorce:

1. $\dot{\alpha} \pi \circ \lambda \hat{v} \sigma \alpha \iota$ (four times) translated to release from service (Apophthegmata Laconica 209.C.4), to release from an oath (Aetia Romana et Graeca 287.D.11), to send a person away (from a group of three, Vitae decem oratorum 838.E.2), warnings against leaving vice unchecked (De Stoicorum repugnantiis 1050.C.1).

2. $\dot{\alpha} \pi 0 \lambda \dot{v} \omega \nu$, (cf. Matt 5:32), was found three times: "freeing the soul of a slavish and suspicious nature" (Quaestiones convivales 716.B.11), 157.77).

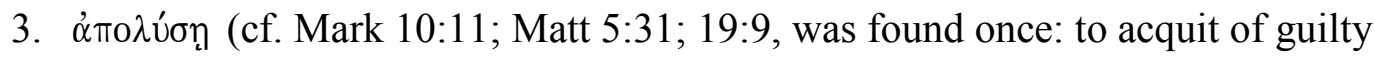
charges (Consolatio ad Apollonium [Letter of Condolence to Apollonius] 108.D.1). Again, as in the previous authors, a search for Plutarch's term for divorce did not turn out any entries.

\section{The First Century CE}

A similar approach, as those above, will be used in analyzing $\dot{\alpha} \pi 0 \lambda u ́ \omega$ and derivatives during the first century CE. Close attention will be given to works related to Jewish-Hellenistic, pagan, and early Christian writers. 


\section{Flavius Josephus, 34-100 CE (6 $^{26}$}

From Jewish Antiquities:

1. To release, to set free, to acquit, to deliver from prison, slavery or captivity, from charges, guilt, fear or distress, disease, drought ( $\left.\dot{\alpha} \pi^{\prime} \hat{\epsilon} \lambda \nu \nu\right) 20.210 .3$, ( $\left.\dot{\alpha} \pi \pi^{\prime} \lambda \nu \sigma \epsilon\right)$ 2.74.3, 8.400.5, 10.154.5, 12.11.5, 13.207.2, 14.240.3, 14.296.5, 14.298.4, 14.410.8,

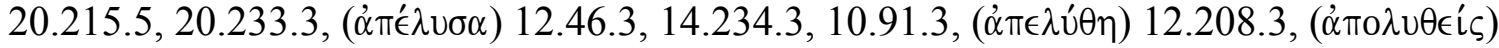

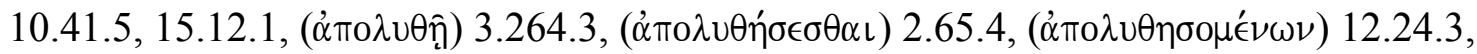

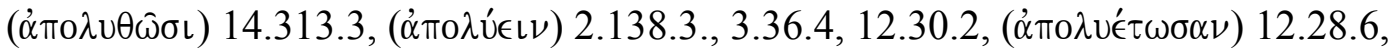

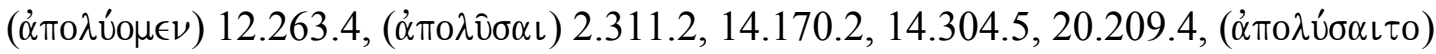

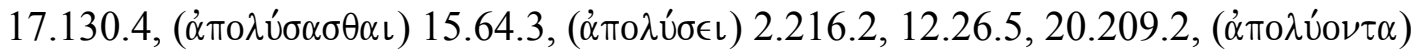

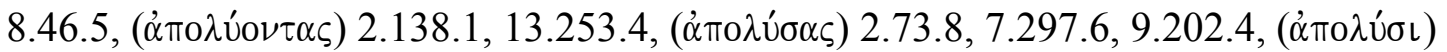

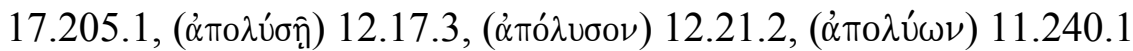

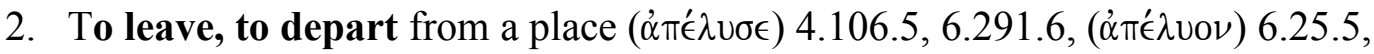

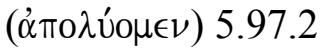

3. To part, to separate from a group, company, family, the soul from the body

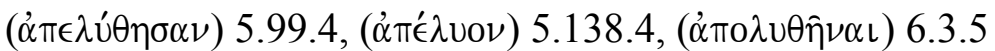

4. To let go a person, i.e, after raping a strange woman, or a people from

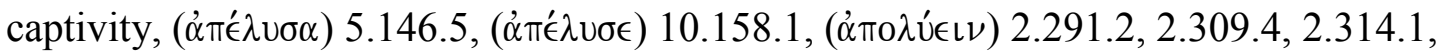

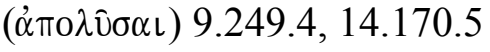

\footnotetext{
${ }^{26}$ Josephus contains almost 200 entries for $\alpha$ mo $\lambda \dot{u} \omega$ and derivatives. The English renditions from the original Greek belong to Josephus (trans. Thackeray, LCL, 1926) and compared with The Works of Josephus (trans. Whiston, 1988).
} 
5. To dismiss people, envoys, an army from service, from a meeting or a hearing (ஷ่ $\left.\pi^{\prime} \lambda \cup \sigma \epsilon\right) ~ 5.263 .1,6.94 .3,7.119 .5,8.370 .5,10.129 .2,10.162 .5,11.337 .3,13.191 .3$,

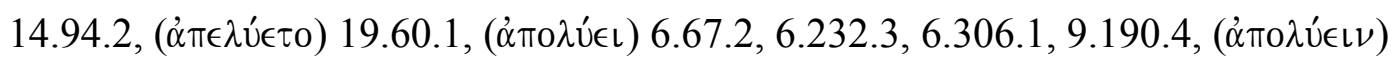

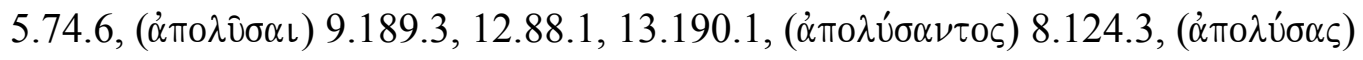
12.301 .3

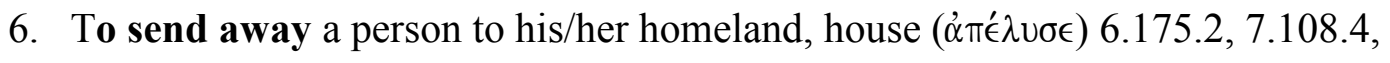

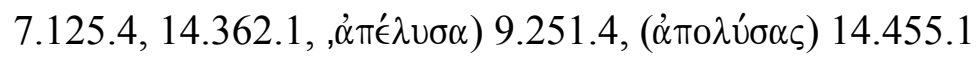

7. To send back a person to his/her homeland, or back to a person of authority

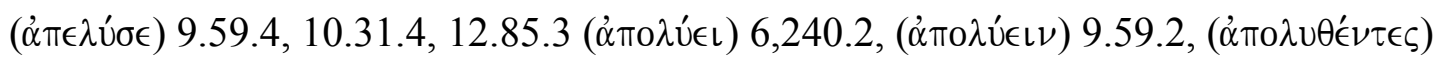

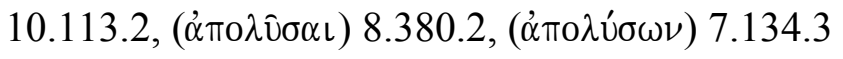

8. To dismiss, as in the termination of employment or from service ( $\dot{\alpha} \pi \epsilon \dot{\epsilon} \lambda \cup \sigma)$ 9.192.2, (ஷ்

9. To be relieved, of thirst, fear, from paying taxes ( $\left.\dot{\alpha}^{\prime} \epsilon^{\prime} \lambda \nu \sigma \epsilon\right)$ 13.237.4,

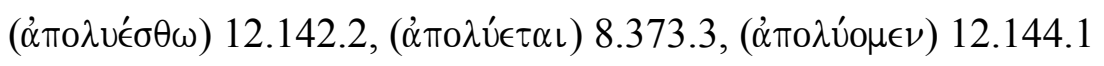

10. To release from military service, so as to die peacefully, from penalties

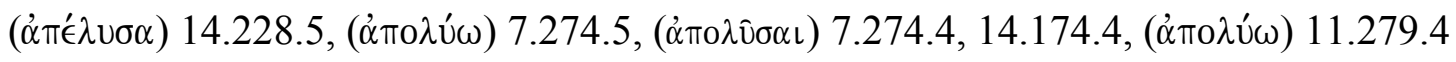

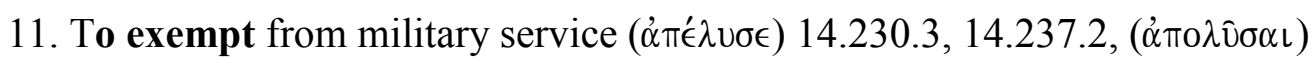

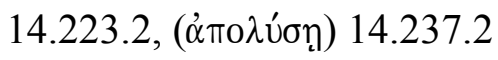

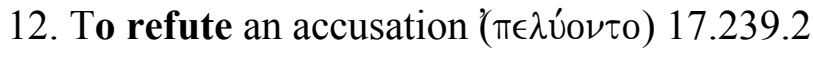

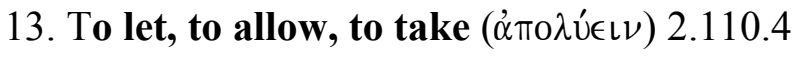

14. To absolve from charges or debt or $\sin (\dot{\alpha} \pi \circ \lambda \dot{\epsilon} \in\llcorner\nu)$ 16.372.3, 17.98.3,

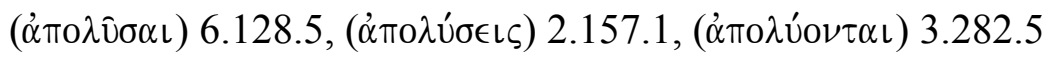

15. To dismiss [disseminate or spread] a disease ( $\alpha$ đo 
16. To discharge [dismiss] from a meeting, reunion or formal reunion ( $\left.\dot{\alpha} \pi{ }^{\prime} \lambda \cup \sigma \iota\right)$

\subsection{4 .7}

17. To dissolve (a marriage, $\dot{\alpha} \pi 0 \lambda$ vou'́́ $\nu \eta)$ 15.259.3.

From The Life:

1. To dismiss, to let go, to discharge from a detention, a prison, to rest [take a

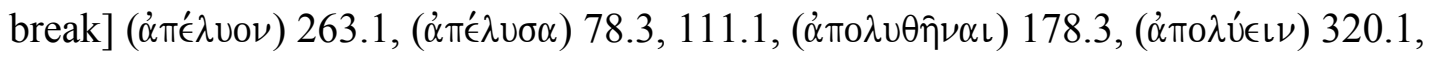
$(\dot{\alpha} \pi 0 \lambda \cup ́ \sigma \alpha \varsigma) 223.2$

2. To leave, to abandon a place or a person $\left(\dot{\alpha} \pi \epsilon^{\prime} \lambda \nu \sigma \alpha\right) 153.6,271.2$

3. To send, to dispatch with a message ( $\dot{\alpha} \pi^{\prime} \dot{\lambda} \lambda$ Uov) 168.4

4. To release from prison or captivity, or from service $\left(\dot{\alpha} \pi^{\prime} \in \lambda \nu \sigma \alpha\right) 419.6$, $(\dot{\alpha} \pi 0 \lambda \dot{v} \sigma \alpha \varsigma) 92.2$

5. To let go for a special business $(\dot{\alpha} \pi \mathrm{0} \lambda u ́ \sigma \alpha \varsigma) 77.1$.

From The Jewish War:

1. To acquit, to quash, to let go, to clear of charges or suspicion ( $\left.\dot{\alpha}^{\prime} \epsilon^{\prime} \lambda v \sigma \epsilon\right)$

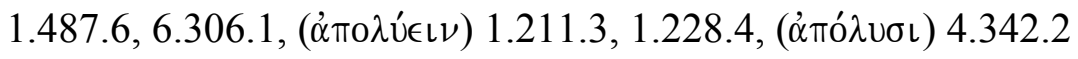

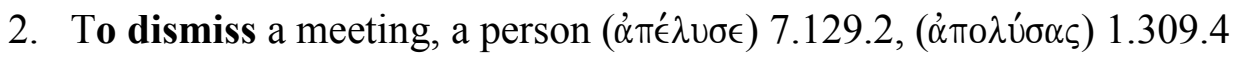

3. To release, to let loose from prison, servitude or from a death sentence

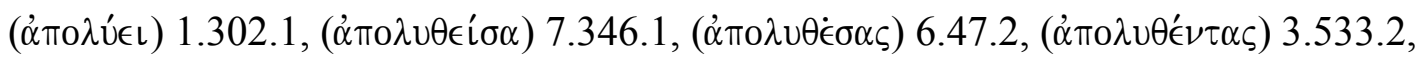

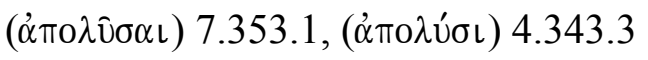

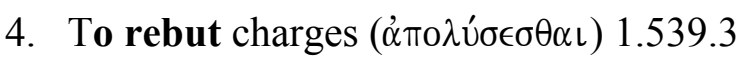

5. To leave, to depart ( $\alpha$ mo $\lambda v \theta \epsilon i ́ \eta) 1.607 .4$

6. To abolish taxes ( $\dot{\alpha} \pi 0 \lambda \dot{v} \epsilon \iota \nu) 2.3 .4$

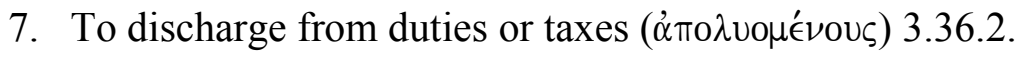


In the semantic development of words, $\dot{\alpha} \pi 0 \lambda \dot{v} \omega$, in the first century CE, appears to continue to mean and be used in the same manner as in the first century BCE. The LCL's

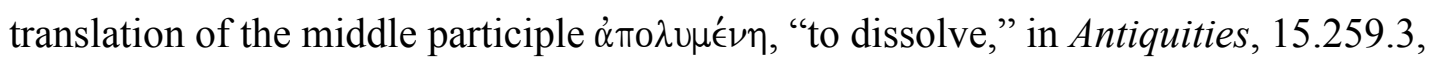
stems from the Salome-Costobarus marriage, in which "she sends him a letter ${ }^{27}$ ( $\pi \dot{\epsilon} \mu \pi \epsilon \iota$

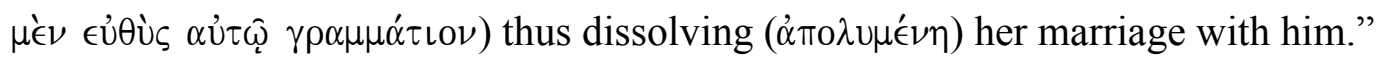
Josephus writes: "[It] was not in accordance with Jewish law, for it is (only) the man who is permitted by us to do this [to divorce his wife], and not even a divorced

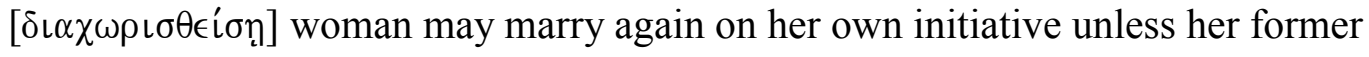
husband consents. ... Salome, however, did not choose to follow her country's law ... telling her brother Herod that she had separated ( $\dot{\alpha} \pi 0 \sigma \tau \eta \hat{\nu} \alpha \iota)$ from her husband." 28

In Salome's eyes, she divorced her husband by writing him a letter as prescribed by Jewish law, but to Josephus, that was inadmissible. To Jewish eyes, Salome

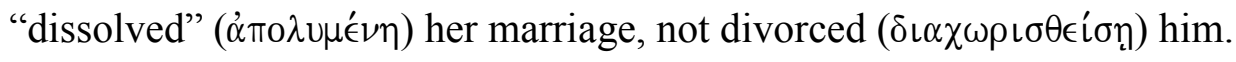

Josephus contains eighteen cognate entries of the derivatives of $\dot{\alpha} \pi \circ \lambda \dot{v} \omega$ as found in the NT. 'Amo $00 \sigma \alpha \iota$ does not invariably mean the same thing in the writings of

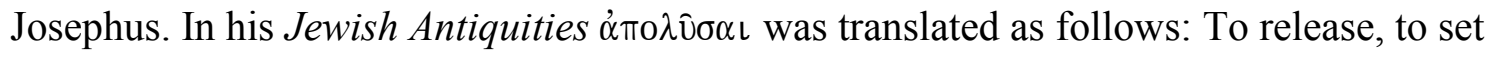
free from bondage or detention $(2.311 .2,9.249 .2,14.174 .4,14.305 .5,20.209 .4)$, to absolve from $\sin (6.128 .5)$, to allow to die (7.274.1), to send back to their home (8.380.2), to dismiss an army from active duty $(9.189 .3,13.190 .1)$, to dismiss those not there to translate the law (12.88.1), to acquit [Herod] of charges (14.170.2), to allow [Herod] to go free (14.170.5), to exempt the Jews from military service (14.223.2). In his Jewish

\footnotetext{
27 "of divorce" is added here by the translators.
} 
War, $\dot{\alpha} \pi 0 \lambda \hat{v} \sigma \alpha \iota$ is found only once and it is translated "to save" from death (7.353.1). 'A тоди́øn, found twice in Jewish War, had cognate meanings as the above: to set the [Jewish] captives free (12.17.3), to exempt the Jews from military service (14.237.2). A compound form of ảmoגúøṇ was also found in Antiquities, 10.158.3. It was translated, "to release himself [from the charges] and his disciple Baruch." Åmo $\lambda \dot{v} \omega \nu$, found once reads, "the queen [Esther] was released from her anxiety" (11.240.1).

One can safely deduce from this oft-quoted Jewish historian that his usage of $\dot{\alpha} \pi \circ \lambda \dot{u} \omega$ and derivatives do not appear to mean divorce. In the two instances where a derivative of $\dot{\alpha} \pi 0 \lambda \cup$ $\omega$ could have meant "to divorce", the translators (both Thackery and Whiston) choose to translate $\dot{\alpha} \pi 0 \lambda \nu \mu \mu^{\prime} \nu \eta$ "to dissolve" within the Jewish understanding that what Salome does is not considered a divorce. ${ }^{29}$

Again, as noted above, it is hard not to notice the structural-grammatical

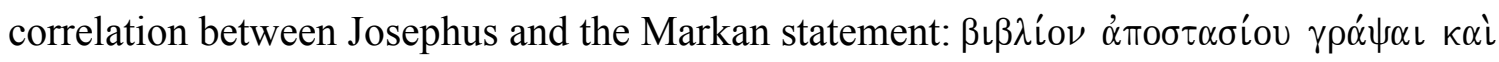
$\dot{\alpha} \pi 0 \lambda \hat{v} \sigma \alpha \iota$ (10:4) where $\dot{\alpha} \pi 0 \lambda \hat{v} \omega$ is the consequence or the act of "releasing", "sending a

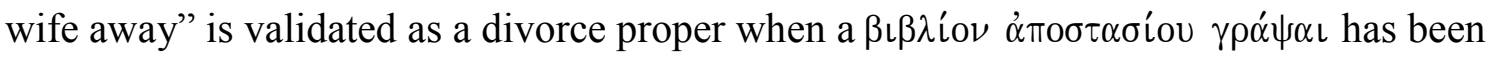
issued. It cannot go without notice that when Josephus does mention divorce, he uses the Greek term $\delta\left\llcorner\alpha \chi \omega \rho i \zeta \omega .^{30}\right.$

\footnotetext{
${ }^{28}$ Josephus Antiquities 15.229.3.

${ }^{29}$ See Josephus Antiquities 15.259.3.

$30 ، . .$. not even a divorced [ $\delta\llcorner\alpha \chi \omega \rho\llcorner\sigma \theta \in i \sigma n]$ woman may marry again on her own initiative unless her former husband consents ...,"Josephus Antiquities 15.229.3.
} 


\section{Clement of Rome, ca. 30 CE to ca. 100 CE}

A derivative of $\dot{\alpha} \pi \mathrm{\lambda} \lambda \dot{\omega} \omega$ is found once in Clement's First Epistle to the

Corinthians: ${ }^{31} 25.2 .3$, dissolution ( $\left.\dot{\alpha} \pi{ }^{1} \lambda \nu \sigma \iota \nu\right)$ as in death. Other derivatives are found a total of 14 times in one of the various works ascribed to him, The Clementine Homilies: ${ }^{32}$

1. To permit, to allow ( $\dot{\alpha} \pi 0 \lambda u ́ \sigma \eta), 3.63 .2$

2. Will be saved ( $\alpha \pi \circ \lambda \nu \theta \eta ́ \sigma \epsilon \tau \alpha \iota), 3.6 .3$

3. To absolve from $\sin (\dot{\alpha} \pi \circ \lambda \cup \theta \eta \dot{\sigma} \sigma \eta), 5.8 .4$; to absolve from wrong doers

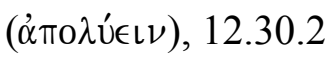

4. To dismiss a multitude, the people $\left(\dot{\alpha} \pi \pi^{\prime} \lambda \cup \in \nu\right), 16.21 .5 ;(\dot{\alpha} \pi 0 \lambda \dot{u} \sigma \alpha \mu \epsilon \nu), 6.26 .3$;

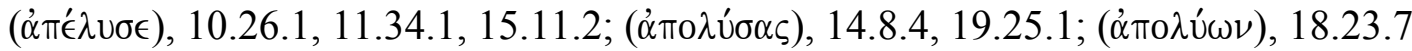

5. To be let off, to be called innocent, to save from punishment ( $\alpha \pi 0 \lambda u ́ \theta \eta \sigma \alpha \nu)$,

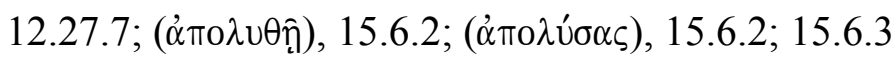

7. To wipe out $\operatorname{sins}(\dot{\alpha} \pi \circ \lambda \hat{v} \sigma \alpha \iota), 20.19 .10$. We found four instances in which derivatives of $\dot{\alpha} \pi 0 \lambda \dot{u} \omega$ are cognate to those found in the NT: $\dot{\alpha} \pi \circ \lambda \dot{u} \sigma \eta$ (once) translated "to

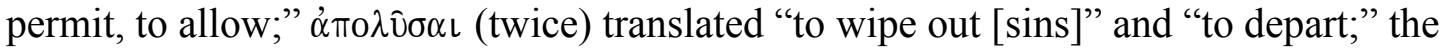
participle $\alpha \operatorname{\pi } 0 \lambda \hat{u} \omega \nu$ (once) translated "to dismiss [a crowd]."

Again, in these mid to late first-century works, $\dot{\alpha} \pi 0 \lambda$ ú $\omega$ or its derivatives do not appear to be connected with divorce. A search for the preponderant term for divorce

${ }^{31}$ The Apostolic Fathers, trans. Bart D. Ehrman, LCL (Cambridge, MA: Harvard University Press, 2003), 1:83.

${ }^{32}$ Alexander Roberts and James Donaldson, eds., The Ante-Nicene Fathers (Grand Rapids, MI: Eerdmans, 1951), 8:323-346. 
during this period, $(\delta\llcorner\alpha) \chi \omega \rho \mathfrak{\imath} \zeta \omega$, in Clement or in any of the Pseudo-Clementine works did not produce any results.

\section{Dio Chrysostom, ca. 40 to ca. $120 \mathrm{CE}^{33}$}

The derivatives of $\dot{\alpha} \pi 0 \lambda \dot{u} \omega$ found in Dio Chrysostom are translated in the following manner: From Orationes (Prayers):

1. Getting rid of vices $\left(\dot{\alpha} \pi 0 \lambda \cup \theta^{\prime} \in \tau \alpha \varsigma\right), 34.19 .4$

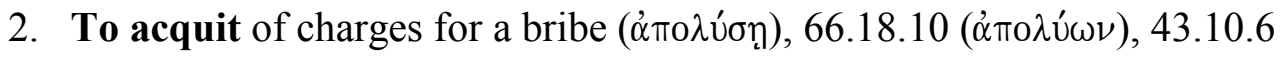

3. To release from an illness through healing ( $\left.\dot{\alpha} \pi{ }^{\prime} \lambda \nu \sigma \iota\right), 77 / 78.45 .9$

4. To be free from ignorance ( $\dot{\alpha} \pi 0 \lambda v \theta \hat{\eta} \nu \alpha \iota), 11.40 .1$. Two of Chrysostom's use of the derivatives of $\dot{\alpha} \pi 0 \lambda \hat{u} \omega$ were found to parallel those in the NT: $\dot{\alpha} \pi 0 \lambda \dot{u} \omega \nu$ and $\dot{\alpha} \pi 0 \lambda \dot{\sigma} \sigma \emptyset$. In both cases they mean acquittal of charges. None of the derivatives of $\dot{\alpha} \pi 0 \lambda u ́ \omega$ are connected with divorce. Dio Chrysostom does not appear to contain any reference to a divorce procedure nor was $(\delta\llcorner\alpha) \chi \omega \rho i \zeta \omega$ or derivatives found.

\section{Epictetus $^{34}$}

From his Dissertationes (Discourses):

1. "For this reason we have sent away ( $\alpha \pi \circ \lambda \cup ́ \sigma \alpha \mu \epsilon \nu)$ the women," 1.29 .66

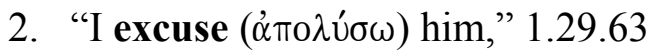

\footnotetext{
${ }^{33}$ James Wilfred Cohoon and Henry Lamar Crosby, trans., Dio Chrysostom, LCL (Cambridge, MA: Harvard University Press, 1932).

${ }^{34}$ William Abbott Oldfather, Trans., The Discourses As Reported by Arrian, the Manual, and Fragments (Cambridge, MA: Harvard University Press, 1928-1946). Oldfather's translation was compared to Elizabeth Carter, trans., The Moral Discourses of Epictetus (New York: Dutton, 1910), and George Long, trans., The Discourses of Epictetus (New York: Hurt, 1878); the results in the three translations were the same.
} 
3. "And to have God as your maker and father and guardian, shall not this

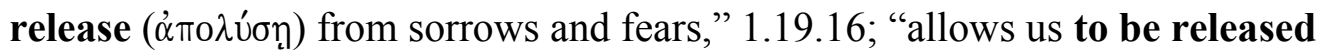
$\left(\dot{\alpha} \pi \circ \lambda \hat{U}_{\epsilon \sigma \theta \epsilon)}\right.$ from these bonds," 1.19.16

4. "You are no longer a man if you are detached ( $\alpha$ mó $\lambda \cup \tau o \nu)$ from other men," 2.5.24, 25

5. "It is said, as it might be said, if we were separated ('̊丿ó $\lambda u \tau o \iota)$ from society," 2.5.24; "For they are not separated ( $\dot{\alpha}$ mó $\lambda u \tau o \iota)$ from communion with other beings," 2.6.12; "consider then from what things you have been separated ( $\alpha$ mó $\lambda \cup \tau 0 \nu)$ by reason," 2.10.4. From his Gnomologium: (1) "If you are released ( $\dot{\alpha} \pi \mathrm{\lambda} \lambda \theta \hat{\eta} \varsigma)$ from suffering," 38.2 .

The slave-Stoic philosopher, Epictetus, contains fourteen entries of the derivatives of $\alpha \pi \circ \lambda u ́ \omega$. Most of these are related to the concept of "release" or "separation" but not in the context of divorce. The only entry equal to a derivative found in the NT is $\dot{\alpha} \pi 0 \lambda \dot{u} \sigma \eta$ translated, "released from fears." Again, most mid to late first century writers, and those who wrote in the early stages of the second century CE, do not appear to use $\alpha$ mo $\lambda$ ú $\omega$, or any of its derivatives, in connection with divorce, nor was there found a word translated "to divorce."

\section{The Second Century CE}

\section{The Apostolic Fathers ${ }^{35}$}

The Martyrdom of Polycarp ${ }^{36}$

\footnotetext{
${ }^{35}$ Ehrman's translation $\{*\}$ of the Shepherd of Hermas in The Apostolic Fathers, will be compared with Kirsopp Lake's $\left\{{ }^{* *}\right\}$, The Apostolic Fathers, LCL (Cambridge: Harvard University Press, 1948).
} 
There was only one entry in The Martyrdom, "Take the oath, and I will release $(\dot{\alpha} \pi \circ \lambda \cup ́ \sigma \omega)$ you $\{*, * *\}, " 9.3 .2$.

The Shepherd of Hermas

From Mandates: "he should divorce $\{*, * *\} "(\dot{\alpha} \pi 0 \lambda \cup ́ \sigma \alpha \tau \omega), 4.1 .6 .3$; "if he marries someone else after the divorce $\{*, * *\} "(\dot{\alpha} \pi 0 \lambda v ́ \sigma \alpha \varsigma), " 4.1 .6 .4$; "if after the wife is divorced $\{*, * *\},(\dot{\alpha} \pi 0 \lambda v \theta \hat{\eta} \nu \alpha \iota), 4.1 .7 .1$.

From Parables: "And he sent them off $\left(\dot{\alpha} \pi \pi^{\prime} \lambda \nu \sigma \in l \varsigma\right)$ into the tower $\{*, * *\}$," 8.2.1.5; "and he sent off $\{*\}$ away $\{* *\}\left(\dot{\alpha} \pi^{\prime} \lambda \cup \sigma \epsilon\right)$ those who had given up," 8.2.4.2. (2)

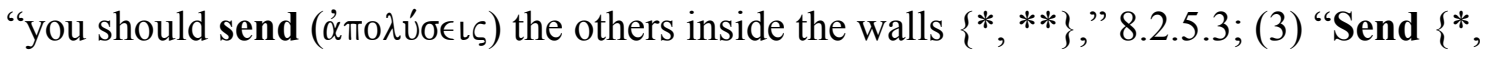

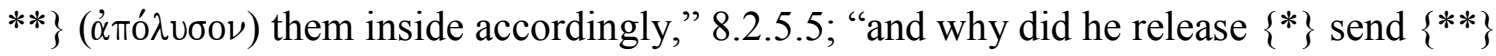
$\left(\dot{\alpha} \pi^{\prime} \dot{\lambda} v \sigma \epsilon\right)$ some into the tower?," 8.3.5.2. (4) "All these were sent $\{* *\}$ off $\{*\}$ ( $\dot{\alpha} \pi 0 \lambda \cup ́ \theta \eta \sigma \alpha \nu)$ each to his own station," 8.5.2.5.

The Shepherd contains ten derivatives of $\dot{\alpha} \pi \mathrm{0} \lambda \dot{\omega} \omega$. Although none of them appear in the grammatical form as they appear in the NT, the Shepherd is illuminating in the sense that three of his ten usages, all three found in Mandates, is the first post NT work in which $\dot{\alpha} \pi \mathrm{o} \lambda \dot{v} \omega$ is translated "to divorce" by Lake, Ehrman, and Lightfoot. The context which appears to merit a translation "to divorce," is a conversation between the Shepherd and "the Lord" in which there is a hypothetical adulterous relationship on the part of his wife.

${ }^{36}$ Ehrman, Apostolic Fathers; cf. J. B. Lightfoot and J. R. Harmer, trans., Apostolic Fathers, $2^{\text {nd }}$ ed., ed. Michael W. Holmes (Grand Rapids, MI: Baker, 1989) and The Apostolic Fathers: Greek Texts and English Translations, ed. Michael W. Holmes (Grand Rapids, MI: Baker, 1999). 
At first sight, the terms for divorce seem to correlate with the Matthean teaching on the subject. Upon a close examination, however, the Shepherd departs from the Matthean saying of Jesus in that the Shepherd is forbidden to remarry even where there has been "unfaithfulness" by the wife. Lake, however, makes an interesting notation to his translation of the Mandates (4.1.3-8) in which he disavows the possibility that $\dot{\alpha} \pi 0 \lambda \cup ́ \omega$ or derivatives could possible mean "to divorce." His commentary reads as follows:

This mandate is really explaining the practical problem which arose from the condition between the Christian precept against divorce (Mt. 10, $11 \mathrm{f}$.) and the equally early precept against having intercourse with immoral persons. As the inserted clause "except for the cause of fornication" in the Matthean version of Mk. 10. 11. F. (Mt. 19, 9; cf. Mt. 5, 32 and Lc. 16, 18) shows, the latter precept was regarded as more important, and immoral, wives were put away, but Hermas and other writers always maintained that this was not strictly divorce [emphasis supplied], as the innocent party was not free to remarry in order to give the other the opportunity of repenting and of returning. ${ }^{37}$

This is the only instance where a derivative of $\alpha$ mo $\lambda$ ú $\omega$ could possibly have meant "to divorce." A perusal of the TLG did not come up with the preponderant term for divorce for this period: $(\delta\llcorner\alpha) \chi \omega \rho \hat{\imath} \zeta \omega$.

The New Testament Apocrypha ${ }^{38}$

From the Acta Pauli et Theclae: "Take compassion of me and I will release

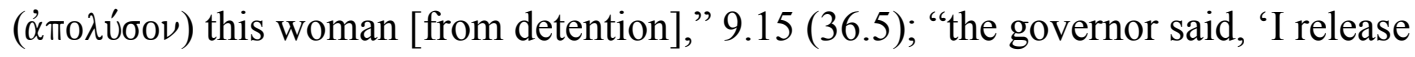

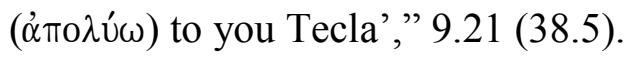

\footnotetext{
${ }^{37}$ Lake, Apostolic Fathers, 2:79, 81.

${ }^{38}$ Montague Rhodes James, trans., The Apocryphal New Testament (Oxford: Clarendon, 1924); and Montague Rhodes James, trans., The Apocryphal Books of the New Testament (Philadelphia: David McKay, 1901).
} 
From the Martyrium Pauli: "We entreat thee, help us, and we will let thee go

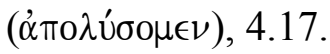

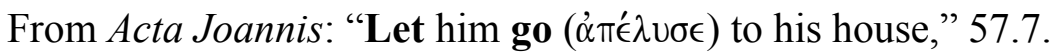

From Protevangelium Jacobi: “'Neither do I condemn you,' and he let him go

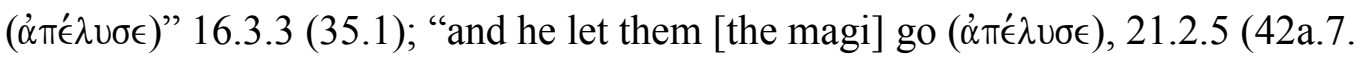

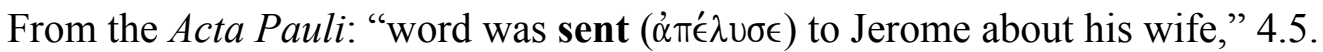

From the Apocalipsis Joannis: "And the holy [church] to the holy ones, those who are sent $(\dot{\alpha} \pi 0 \lambda \cup \dot{\sigma} \epsilon \omega \varsigma)$ to the holy [churches]," 36.4; "and to send ( $\dot{\alpha} \pi 0 \lambda \hat{v} \sigma \alpha \iota)$ [the woman] into the abyss," 20.7.

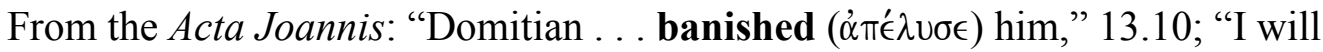
defend myself before justice, that I have the right to have deserted ( $\left.\dot{\alpha} \pi \circ \lambda v^{\prime} \omega \nu\right), " 20.12$; "possessing these things ye provide for yourselves grief that ye cannot be rid of

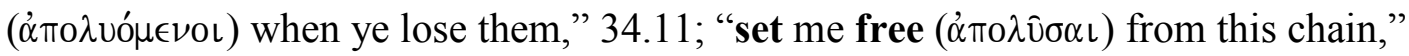
64.10 .

$\AA \AA \pi 0 \lambda \cup ́ \omega$ and derivatives were found a total of thirteen times. One would expect to find $\dot{\alpha} \pi 0 \lambda \hat{v} \omega$ somehow mentioned in connection to divorce. It is not, despite the fact that four of the thirteen times derivatives appear in the same grammatical forms as they do in the NT. No other word for divorce could be gleaned from the NT Apocrypha.

Appianus of Alexandria, $95-165 \mathrm{CE}^{39}$

From The Civil Wars: 1972).

\footnotetext{
${ }^{39}$ Horace White, trans., Appian's Roman History, LCL (Cambridge: Harvard University Press,
} 
1. To dismiss $\left(\dot{\alpha} \pi \epsilon^{\prime} \lambda \cup \epsilon\right), 1.13 .114 .27,2.6 .43 .29,5.13 .129 .9,\left(\alpha \pi^{\prime} \lambda \nu 0 \nu\right)$ 4.12.101.8,

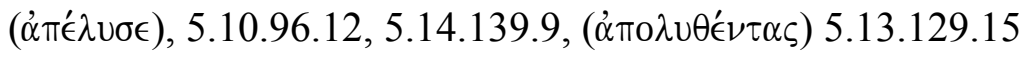

2. To pass $\left(\dot{\alpha} \pi \pi^{\prime} \lambda \cup \epsilon\right)$ a new law, 3.14.195.1

3. To release ( $\left.\dot{\alpha} \pi \epsilon^{\prime} \lambda \nu \sigma \epsilon\right)$ from prison, 4.6.50.23, (( $\left.\dot{\alpha} \pi 0 \lambda \dot{\sigma} \sigma \epsilon \iota \nu\right), 5.13 .129 .16$, from a

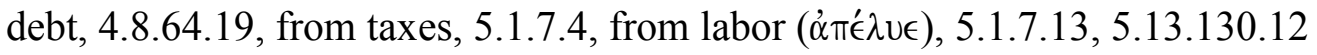

4. To flee $(\dot{\alpha} \pi \dot{\epsilon} \lambda \cup \epsilon), 5.1 .4 .5$

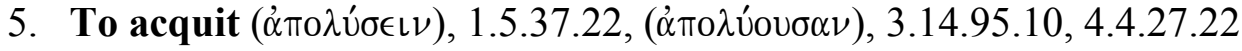

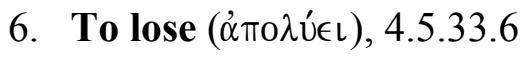

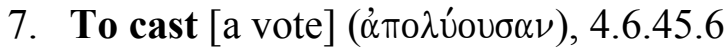

8. To be discharged ( $\dot{\alpha} \pi \circ \lambda \nu \theta \hat{\eta} \nu \alpha \iota)$ from a duty or service, 5.13.128.3,

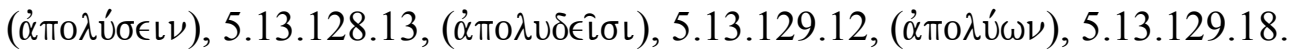

From The Syrian Wars:

1. To be relieved $\left(\dot{\alpha} \pi \pi^{\prime} \lambda \nu \sigma \epsilon\right), 9.4 .21 .3$

2. To release $\left(\dot{\alpha} \pi \epsilon^{\prime} \lambda \nu \sigma \alpha \nu\right)$ from a debt, 9.5.23.13, from captivity ( $\left.\dot{\alpha} \pi \epsilon \lambda \dot{v} \sigma \alpha \mu \epsilon \nu\right)$, 9.5.23.20, from acting ( $\alpha$ mо $\lambda \nu \theta \hat{\eta} \nu \alpha \iota), 11.8 .47 .3$

3. To acquit ( $\left.\dot{\alpha} \pi^{\prime} \hat{\lambda} \nu \sigma \alpha \tau \epsilon\right), 11.7 .41 .27$. (4) To dispose of $\left(\dot{\alpha} \pi \pi^{\prime} \lambda \nu \sigma \alpha \nu\right)$ the land, 11.8.44.12.

Clement of Alexandria, ca. 150 to ca. $220 \mathrm{CE}^{40}$

The works of Clement contain twenty-one entries for $\dot{\alpha} \pi 0 \lambda \dot{u} \omega$ and derivatives.

\footnotetext{
${ }^{40}$ Roberts and Donaldson, Fathers, 2:166, 209, 304. The original Greek text is from Ursula Treu, ed., Clement Alexandrinus, Griechischen Christlichen Schriftsteller der Ersten Jahrhunderte (Berlin: Akademie, 1960-1980), 1:35; and Ludwig Früchtel, ed., Clemens Alexandrinus, Griechischen Christlichen Schriftsteller der Ersten Jahrhunderte (Berlin: Akademie, 1960-1980), 2:23 and 3:24.
} 
From the Protrepticus: to break ( $\dot{\alpha} \pi \mathrm{\nu} \nu \dot{\sigma} \emptyset \tau \alpha \iota)$ the silence, 1.9.2.5.

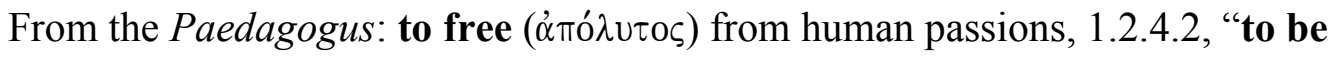

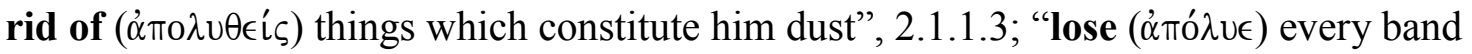
of wickedness" [quoting Isaiah 58:6], 3.12.90.2.

From the Stromata: ${ }^{41}$

1. To free ( $\left(\dot{\alpha} \pi \mathrm{\alpha} \lambda v^{\prime} \epsilon \nu\right)$ the soul from the body, 5.8.55.2; to free $\left(\dot{\alpha} \pi \circ \lambda \nu \theta^{\prime} \nu \tau \omega \nu\right)$ from all punishment, 7.10.56.3. To set (us) free ( $\dot{\alpha} \pi \mathrm{o} \lambda \dot{\omega} \omega \mathrm{v})$ from sensuality, 3.5.44.4

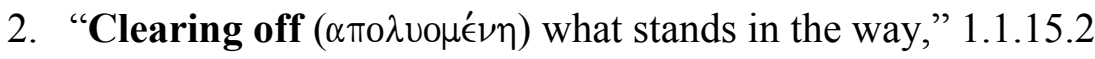

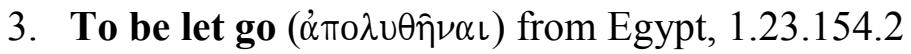

4. "He that loses $(\dot{\alpha} \pi 0 \lambda \dot{v} \sigma \alpha \varsigma)$ his life, shall save it," 2.20.108.3

5. Put away ( $\dot{\alpha} \pi \circ \lambda \dot{v} \sigma \in \iota \varsigma)$ a wife, 2.23.145.3; "he that taketh a woman that has

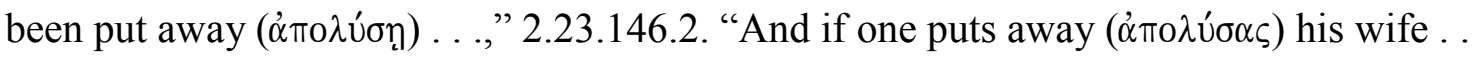

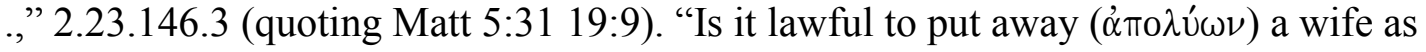
Moses commanded?" This is not a direct quotation, but an interpretation of Matt 19:3), 3.6.47.2.

6. "To divorce" (’่mo $\lambda \dot{v} \omega \nu)$, "He who divorces his wife, except for fornication, makes her an adulterer", (a quotation of Matt 19:9), 3.6.47.2

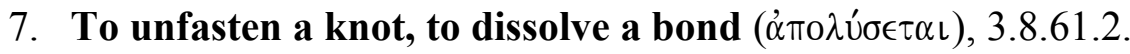

8. To depart ( $\dot{\alpha} \pi 0 \lambda v \theta \dot{\sigma} \sigma \in \tau \alpha \iota)$ from this life, 4.4.14.1

\footnotetext{
${ }^{41}$ English renditions were gleaned from John Ernest Leonard Oulton and Henry Chadwick, trans., Alexandrian Christianity, LCC (Philadelphia: Westminster, 1954), 2:40-92.
} 


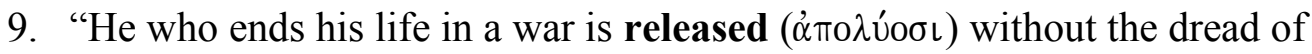

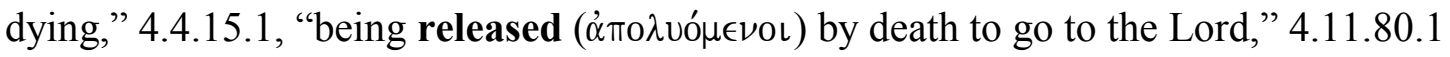

10. "Righteousness is the peace of life and a well-conditioned state, to which the Lord dismissed [death] ( $\left.\dot{\alpha} \pi^{\prime} \lambda \cup \sigma \epsilon\right)$ her when he said, 'depart in peace'," 4.25.161.3.

In Clement's commentary of the Matthean "divorce" passages, we find the following terms, three of which are cognate to those found in the NT: $\dot{\alpha} \pi 0 \lambda \dot{v} \sigma \in \iota \varsigma$,

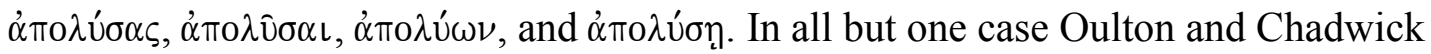
translate these terms "to put away." Except for the participial $\alpha \pi 0 \lambda \dot{u} \omega \nu$ translated "to divorce", it seems that Oulton and Chadwick relied on the KJV for their translation. Now, when Clement makes a direct reference to divorce, he uses the neuter, perfect, participle $\chi \in \chi \omega \rho\left\llcorner\sigma \mu \epsilon^{\prime} \nu \mathrm{o \nu}\right.$, the term generally used for divorce in classical Greek.

Right in the middle of his Matthean commentary, Clement writes: "And it [the word of Jesus] regards as fornication the marriage of those divorced ( $\chi \in \chi \omega \rho\llcorner\sigma \mu \in \operatorname{\epsilon } \nu \nu)$ while the other is alive ...,"Strom 2.23.146.1. Clement is in line with the preponderant terms used for divorce in the Greco-Roman and Byzantine periods. ${ }^{42}$

Cassius Dio, ca. 155 to $231 \mathrm{CE}^{43}$

Cassius Dio's Histories contain 49 entries for the derivatives of $\alpha$ mo $\lambda$ ú $\omega$. From the Historiae Romanae:

1. "Although charged with the same crimes, was acquitted ( $\dot{\alpha} \pi \lambda \dot{u} \theta \eta), "$

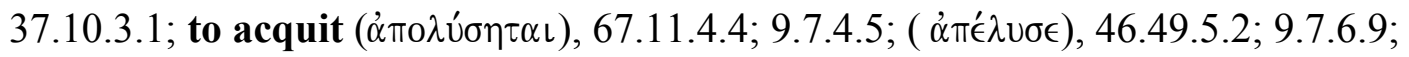

\footnotetext{
${ }^{42}$ For a full treatment, see $114-120$.

${ }^{43}$ Dio, Roman History, vol. 8.
} 


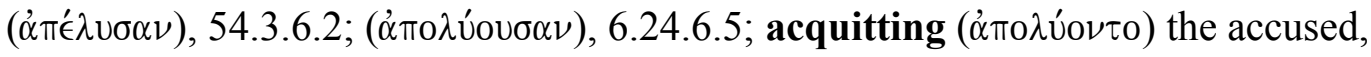

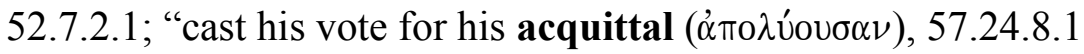

2. "Setting free $\left(\dot{\alpha} \pi \epsilon^{\prime} \lambda \nu \sigma \alpha \nu\right)$ [those who had been arrested]," 37.36.1.2; "he had

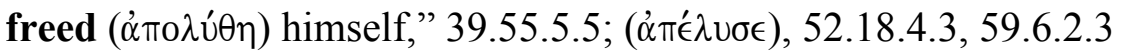

3. "Were allowed to go $(\dot{\alpha} \pi \in \lambda \hat{v} \theta \eta \sigma \alpha \nu), " 41.11 .3 .3 ;(\dot{\alpha} \pi 0 \lambda \hat{v} \sigma \alpha \iota), 55.14 .1 .6$

4. To release ( $\dot{\alpha} \pi \dot{\epsilon} \lambda \nu \sigma \epsilon)$ some who were on trial, 43.47.4.2, 44.39.5.3, 47.34.6.4,

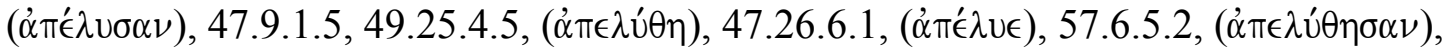

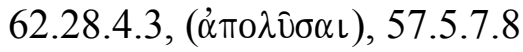

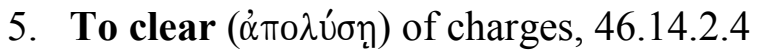

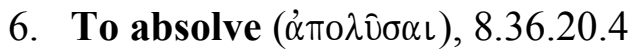

7. To end $(\dot{\alpha} \pi \circ \lambda \dot{v} \sigma \alpha \sigma \theta \alpha \iota)$ all suspicion, 45.8.2.1

8. To refute ( $\dot{\alpha} \pi 0 \lambda \dot{v} \sigma \alpha \sigma \theta \alpha \iota)$ accusations, 46.1.3.1.

None of the four entries cognate to those found in the NT ( $\dot{\alpha} \pi 0 \lambda \hat{v} \sigma \alpha L$, three times,

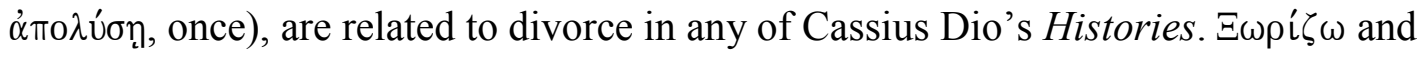
$\delta\llcorner\alpha \chi \omega \rho i \zeta \omega$, however, are interchangeably used for divorce.

Marcus Aurelius Antonius ${ }^{44}$

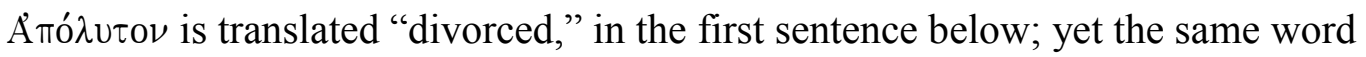
is later translated "delivered" (twice). The context shows that the translator used "divorced" as an idiomatic expression where the meaning is clearly something else: "It is

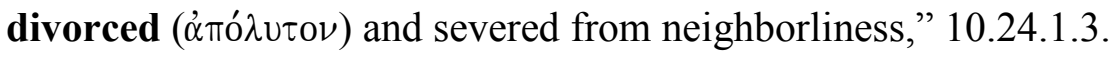

\footnotetext{
${ }^{44}$ Charles Reginald Haines, trans., The Communings with Himself of Marcus Aurelius Antonius, Emperor of Rome, LCL (Cambridge: Harvard University Press, 1961), 279, 295, 323.
} 
2. "What a soul is that which is ready to be released $(\dot{\alpha} \pi 0 \lambda \nu \theta \hat{\eta} \nu \alpha \iota)$ from the body," 11.3.1.1

3. "Thine intellectual faculty delivered ( $\propto \pi 0 ́ \lambda \nu \tau o \nu)$ from the contingencies of destiny," 12.3.1.9

4. "So might a praetor, who commissions a comic actor, dismisses ( $\dot{\alpha} \pi 0 \lambda$ úo $)$ him from the stage," 12.36.1.5; "for he also that dismisses ( $\dot{\alpha} \pi \circ \lambda \dot{u} \omega \nu)$ thee is gracious," 12.36.1.9.

Here again, there are no basic differences from the way most previous writers have made use of $\dot{\alpha} \pi 0 \lambda \dot{u} \omega$ and derivatives. As to words he could have used for divorce, none were gleaned.

\section{Occasional Citations in Other Second Century CE Works}

Ireneus: $:^{45}$ "Send ( $\dot{\alpha} \pi \mathrm{\partial} \lambda \dot{U} \in\llcorner\varsigma)$ your servant in peace now, master, according to your word," Adversus haeresis 1.1.17.5.

Corpus Hermeticum: ${ }^{46}$

1. "And when we have been separated ( $\dot{\alpha} \pi \circ \lambda v \theta \epsilon i \sigma \alpha \varsigma)$ from these things,"

23.27 .1

2. "Once released $(\dot{\alpha} \pi 0 \lambda \nu \theta \epsilon \hat{\imath} \sigma \alpha \iota)$ from the body ...," 25.1.4; "to be released $(\dot{\alpha} \pi \circ \lambda \nu \theta \hat{\eta} \nu \alpha \iota)$ from prison," 25.6.9.

Justin Martyr: ${ }^{47}$

${ }^{45}$ Roberts and Donaldson, Fathers, 1:317.

${ }^{46}$ André Jean Festugière, trans., Corpus Hermeticum (Paris: Societé D’Édition Les Belles Lettres, 1954-1960), 4:74, 77. 
1. "But let us now dismiss ( $\alpha$ mо $\lambda \cup \theta \in \hat{\imath} \sigma \alpha \iota)$ this subject." Dialogue with Trypho

\subsection{2.}

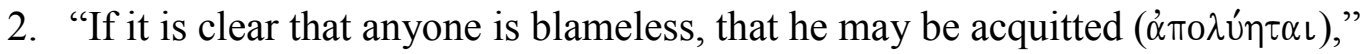
First Apology 7.4.4.

Papias of Hieropolis: ${ }^{48}$ “After Domitian, Nerva reigned for one year. He recalled John from the island [Patmos] and allowed ( $\left.\dot{\alpha}^{\prime} \epsilon^{\prime} \lambda \nu \sigma \epsilon^{49}\right)$ to live in Ephesus."

Melito of Sardis: ${ }^{50}$ "I, the one condemned, departed ( $\left.\dot{\alpha} \pi \pi^{\prime} \lambda \cup \sigma \alpha\right)$, , De Pascha 775.

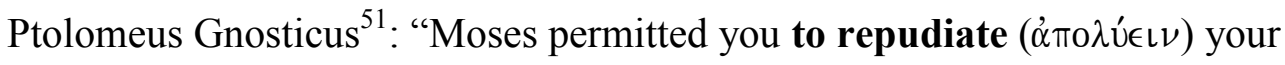
wives, Letter to Flora 4.4.4.

\section{Summary and Conclusions}

The above analysis seems to show with a certain degree of probability that the lack of mention of divorce in most of the Hellenistic and classical Greek literature of the first century BCE, the first century and early to mid second century $\mathrm{CE}$ may be due to the fact that divorces were no longer matter of the state for the majority of the population under Roman rule. The preponderant term used for divorce is $\left(\delta\llcorner\alpha) \chi \omega \rho \hat{\imath} \zeta \omega^{52}\right.$; term used by Josephus (Antiquities, 15.7.4), Mark (10:9), Paul (1 Cor 7:15) and others.

${ }^{47}$ Roberts and Donaldson, Fathers, 1:164, 165.

${ }^{48}$ Fragmenta 12.1.2; J. B. Lightfoot and J. R. Harmer, Apostolic Fathers, 318.

${ }^{49}$ John J. Jepson translates $\dot{\alpha} \epsilon \in \lambda \cup \sigma \epsilon$ "let him free," "St. Augustine," Ancient Christian Writers (Westminster, MD: Newman, 1948), 5:123.

${ }^{50}$ Stuart George Hall, ed., Melito of Sardis (Oxford: Clarendon, 1979), 133.

${ }^{51}$ Gilles Quispel, trans., Ptolémée Lettre a Flora, Sources Chrétiennes (Paris: Du Cerf, 1966), 24:66.

\footnotetext{
${ }^{52}$ For a complete analysis see chapter 4.
} 


\section{BIBLIOGRAPHY}

Abbot, Frank Frost. Society and Politics in Ancient Rome. New York: Charles Scribner's Sons, 1918.

Abrahams, Israel. Studies in Pharisaism and the Gospels. New York: Ktav, 1967.

Agylaeus, Henricus, Gaius, Domitius Ulpianus, and Julius Paulus. The Civil Law, Including the Twelve Tables, the Institutes of Gaius, the Rules of Ulpian, the Opinions of Paulus, the Enactments of Justinian, and the Constitutions of Leo. 17 vols. Edited and translated by Samuel Parsons Scott. Cincinnati: Central Trust, 1932.

Aland, Kurt, ed. Synopsis quattuor evangeliorum. 10th ed. Stuttgart: Deutsche Bibelstiftung, 1979. . Synopsis of the Four Gospels. 3rd ed. New York: United Bible Societies, 1985.

Aland, Kurt, Barbara Aland, Matthew Black, Carlo M. Martini, Bruce M. Metzger, and Allen Wikgren, eds. The Greek New Testament. 4th rev. ed. New York: United Bible Societies, 1993.

Albright, William F., and Christopher Steven Mann. Matthew: Introduction, Translation, and Notes. Vol. 26 of the Anchor Bible Reference Library. New York: Doubleday, 1971.

Allen, Leslie C., and Timothy S. Laniak. "Ezra, Nehemiah, Esther.” New International Bible Commentary, edited by Robert L. Hubbard and Robert K. Johnston. Peabody, MA: Hendrickson, 2003.

Allen, W. C. The Gospel according to St. Mark. London: George Bell, 1915.

Anderson, Hugh. The Gospel of Mark. New Century Bible. London: Oliphants, 1976.

Arendzen, J. P. "Ante-Nicene Interpretations of the Sayings on Divorce." Journal of Theological Studies 20 (1919): 230-241.

Alt, Albrecht. "The Origins of Israelite Law." In Essays on Old Testament History and Religion, 79-132. Translated by R. A. Wilson. Oxford: Basil Blackwell, 1966.

Avi-Yonah, Michael. The Herodian Period. The World History of the Jewish People 7. London: Allen, 1975. 
Bacchiocchi, Samuel. Divorce and Remarriage in Matthew. Berrien Springs, MI: Biblical Perspectives, 2000.

. Divorce and Remarriage Today. Berrien Springs, MI: Biblical Perspectives, 2000.

Bach, D. L. "Background of 1 Cor VII: Sayings of the Lord in Q." New Testament Studies 18 (1971-1972): 351-364.

Bacon, Benjamin W. Is Mark a Roman Gospel? Cambridge: Harvard University Press, 1919.

. Studies in Matthew. New York: Holt, 1930.

Bailey, Derrick Sherwin. The Mystery of Love and Marriage. New York: Harper \& Brothers, 1952.

Baker, David W. "Diversity and Unity in the Literary Structure of Genesis." In Essays on the Patriarchal Narratives, edited by Alan R. Millard and Donald J. Wiseman, 189-205. Leicester, UK: InterVarsity, 1980.

Balsdon, John Percy Vyvian Dacre. Roman Women: Their History and Habits. Westport, CT: Greenwood, 1975.

Baltensweiler, Heinrich. Die Ehe im Neuen Testament. Zurich: Zwingli Verlag, 1967.

Bammel, Ernst. "Markus 10:11f. und das jüdische Eherecht." Zeitschrift für die Neutestamentliche Wissenchaft 61 (1970): 95-101.

Banks, Robert. Jesus and the Law in the Synoptic Tradition. New York: Cambridge University Press, 1975.

Barnett, Paul. Jesus and the Rise of Early Christianity. Downers Grove, IL: InterVarsity, 1999.

Barrett, Charles K. A Commentary to the First Epistle to the Corinthians. Peabody, MA: Hendrickson, 1987.

Bartlet, James Vernon. St. Mark: An Introduction. Vol. 19 of The New Century Bible. New York: H. Frowde, 1925.

Bartling, Walter J. "Sexuality, Marriage, and Divorce in 1 Corinthians 6:12-7:16." Concordia Theological Monthly 39 (1968): 355-366.

Batey, Richard A. Jesus and the Forgotten City: New Light on Sepphoris and the Urban World of Jesus. Grand Rapids, MI: Baker, 1991. 
Bauer, Walter. A Greek-English Lexicon of the New Testament and Other Early Christian Literature. Edited by Frederick W. Danker, William F. Arndt, and Wilbur F. Gingrich. $3^{\text {rd }}$ ed. Chicago: University of Chicago Press, 2000.

Beer, Moshe. "Theudas of Rome and Emperor Worship in the Reign of Domitian." Zion 26 (1961): 238-239.

Bell, Albert A., Jr. Exploring the New Testament World. Nashville, TN: Thomas Nelson, 1998.

Benoit, Pierre, Jozef T. Milik, and Roland de Vaux. Les Grottes de Murabba'ât. The Discoveries in the Judean Desert. 2 vols. Oxford: Clarendon, 1961.

Berger, Adolf. Encyclopedic Dictionary of Roman Law. Union, NJ: Lawbook Exchange, 2002.

Berger, Klaus. Die gesetzesauslegung Jesu. Neukirchen-Vluyin: Neukrichener, 1972.

Best, Ernest. Following Jesus: Discipleship in the Gospel of Mark. Sheffield: University of Sheffield, 1981.

. The Temptation and the Passion: The Markan Soteriology. New York: Cambridge University Press, 1990.

Betz, H. D., ed. Christology and a Modern Pilgrimage: A Discussion with Norman Perrin. Claremont, CA: NT Colloquium, 1971.

Bevilacqua, Anthony J. "History of the Indissolubility of Marriage." Proceedings of the Catholic Theological Society of America 22 (1967): 253-308.

La Biblia de las Américas. La Habra, CA: Editorial Fundación, 1986.

Black, Clifton C. "Mark as Historian of God's Kingdom." Catholic Biblical Quarterly 71, no. 1 (January 2009): 64-83.

Black, David Alan, and David R. Beck, eds. Rethinking the Synoptic Problem. Grand Rapids, MI: Baker Academic, 2001.

Black, David Allan, and David S. Dockery, eds. Interpreting the New Testament: Essays on Methods and Issues. Nashville, TN: Broadman and Holman, 2001.

Blass, F., and A. Debrunner. A Greek Grammar of the New Testament. Translated and edited by Robert W. Funk. Chicago: University of Chicago Press, 1961.

Blomberg, Craig L. "Marriage, Divorce, Remarriage, and Celibacy: An Exegesis of Matthew 19:3-12." Trinity Journal 11 (1990): 161-196. 
Bock, Darrell L. "Redaction Criticism." In Interpreting the New Testament: Essays on Methods and Issues, edited by David Allan Black and David S. Dockery, 105133. Nashville: Broadman and Holman.

Bokser, Baruch M. "Rabbinic Authority in Rome." In New Perspectives in Ancient Judaism: Religion, Literature, and Society in Ancient Israel, edited by Jacob Neusner, 1:117-130. Atlanta: Scholars, 1990.

Bonsirven, Joseph. Les Enseignements de Jésus-Christ. Paris: Beauchesne, 1943.

Boobyer, G. H. “Galilee and Galileans in St. Mark's Gospel.” Bulletin of the John Rylands Library 35 (1953): 334-348.

Børgen, Peder, Kåre Fuglseth, and Roald Skarsten. The Philo Index: A Complete Greek Word Index to the Writings of Philo of Alexandria. Grand Rapids, MI: Eerdmans, 2000.

Boring, M. Eugene. Mark: A Commentary. Louisville, KY: Westminster John Knox Press, 2006.

Borkmann, Günther. Jesus of Nazareth. Translated by Irene and Fraser McLuskey. New York: Harper, 1960.

Bowman, John. The Gospel of Mark: The New Christian-Jewish Passover Haggadah. Vol. 8 of the Studia Post-Biblica, edited by P. H. A. DeBoer. Leiden: Brill, 1965.

Branscomb, Bennet Harvie. The Gospel of Mark. London: Hodder \& Stoughton, 1952.

Brenton, Lancelot C. L., trans. The Septuagint with Apocrypha: Greek and English. Regency Reference Library. Grand Rapids, MI: Zondervan, 1988)

Bromiley, Geoffrey W., ed. The International Standard Bible Encyclopedia. 4 vols. Grand Rapids, MI: Eerdmans, 1979.

Bromiley, Geoffrey W., ed. and trans. Theological Dictionary of the New Testament. 10 vols. Grand Rapids, MI: Eerdmans, 1964-1976.

Brooke, Christopher N. L. The Medieval Idea of Marriage. Oxford: Oxford University Press, 1989.

Brooks, James A., and Carlton L. Winbery. Syntax of New Testament Greek. Lanham, MD: The University Press of America, 1979.

Broyde, Michael J. "The Covenant-Contract Dialectic in Jewish Marriage and Divorce Law." In Covenant Marriage in Comparative Perspective, edited by John Witte, Jr., and Eliza Ellison, 51-69. Grand Rapids, MI: Eerdmans, 2005. 
Broyde, Michael J. Marriage, Divorce, and the Abandoned Wife in Jewish Law. Hoboken, NJ: Ktav, 2001.

Brown, Francis, S. R. Driver, and Charles A. Briggs. The New Brown, Driver, and Briggs Hebrew and English Lexicon of the Old Testament. Grand Rapids, MI: Baker, 1981.

Bruce, F. F. The Acts of the Apostles. Grand Rapids, MI: Eerdmans, 1952.

. "The Kingdom of God: A Biblical Survey." Evangelical Quarterly 15 (1943): 263-268.

Brug, John F. "The Betrothal Explanation of Porneia in the Exception Clause." Wisconsin Lutheran Quarterly 105 (Fall 2008): 290-293.

Brunner, Emil. The Divine Imperative. Philadelphia: Westminster, 1947.

Brunt, John C. "What Does the New Testament Say About Divorce?" Spectrum 13 (June 1983): $15-21$.

Bultmann, Rudolf. The History of the Synoptic Tradition. Rev. ed. Translated by John Marsh. Peabody, MA: Hendrickson, 1994.

Buttrick, George A., ed. Interpreter's Dictionary of the Bible. 4 vols. Nashville, TN: Abingdon, 1962.

Calvin, John. Commentary on the Harmony of the Evangelists Matthew, Mark and Luke. Translated by William Pringle. Grand Rapids, MI: Eerdmans, 1949.

Carrell, Peter. "Marriage, Divorce, and Remarriage in the New Testament." Stimulus 11 (2003): 32-35.

Carrington, Phillip. The Primitive Christian Calendar: A Study in the Making of the Markan Gospel. Cambridge: University Press, 1952.

Carson, D. A. Collected Writings on Scripture. Compiled by Andrew David Naselli. Wheaton, IL: Crossway Books, 2010.

. "Matthew." The Expositor's Bible Commentary. Edited by F. E. Gaebelein. 10 vols. Grand Rapids, MI: Zondervan, 1984.

Carter, Elizabeth, trans. The Moral Discourses of Epictetus. New York: E. P. Dutton, 1910.

Case, Shirley Jackson. “Jesus and Sepphoris.” Journal of Biblical Literature 45 (1926): 14-22.

Catchpole, David R. "The Synoptic Divorce Material as a Traditio-Historical Problem." Bulletin of the John Rylands Library 57 (Autumn 1974): 92-127. 
Catullus, Gaius Valerius. Catullus. Translated by G. P. Goold. Loeb Classical Library. Rev. ed. Cambridge: Harvard University Press, 1988.

Chancey, Mark A. Greco-Roman Culture and the Galilee of Jesus. New York: Cambridge University Press, 2005. . The Myth of a Gentile Galilee. New York: Cambridge University Press, 2002.

Chancey, Mark A., and Adam Porter. "The Archaeology of Roman Palestine." Near Eastern Archaeology 64, no. 4 (December 2001): 164-198.

Charles, J. Daryl. "The Greatest or the Least in the Kingdom? The Disciples' Relationship to the Law (Matt 5:17.20)." Society of Biblical Literature (2000): $139-162$.

Charles, Robert H. The Teaching of the New Testament on Divorce. London: Williams and Norgate, 1921.

Charlesworth, James H., ed. The Old Testament Pseudepigrapha. 2 vols. Garden City, NJ: Doubleday, 1983-1985.

Chilton, Bruce. The Kingdom of God in the Teaching of Jesus. Philadelphia: Fortress, 1984.

Cicero, Marcus Tullius. Cicero. Translated by D. R. Shackleton Bailey. Loeb Classical Library. 3 vols. Cambridge: Harvard University Press, 1999. . Letters to Atticus. Translated by D. R. Shackleton Bailey. Loeb Classical Library. 4 vols. Cambridge: Harvard University Press, 1999. . Letters to Atticus. Translated by Eric Otto Winstedt. Loeb Classical Library. 3 vols. Cambridge: Harvard University Press, 1912-1918. . Philippics. Translated by Walter C. A. Ker. Loeb Classical Library. Cambridge: Harvard University Press, 1938.

Clark, K. W. "Galilee." The Interpreter's Dictionary of the Bible. Edited by George Arthur Buttrick. Nashville: Abingdon, 1962. 2:334-347.

Cochoud, Paul Louis. Le mystère de Jésus. Paris: F. Rieder, 1924.

Cohen, Boaz. Jewish and Roman Law: A Contemporary Study. 2 vols. New York: Jewish Theological Seminary of America, 1966.

Cohen, Shaye J. D. “Epigraphical Rabbis.” Jewish Quarterly Review 72 (1981): 1-17.

Cohoon, James Wilfred, and Henry Lamar Crosby, trans. Dio chrysostom. Loeb Classical Library. 5 vols. Cambridge: Harvard University Press, 1932. 
Coiner, H. G. "Those Divorce-Marriage Passages (Matt 5:32; 19:9; 1 Cor 7:10-16)." Concordia Theological Monthly 39 (1988): 367-384.

Cole, William Graham. "The Church and Divorce: Historical Background." Pastoral Psychology 9 (September 1958): 39-44.

Collins, Adela Yarbro. Mark: A Commentary. Edited by Harold W. Attridge. Hermeneia: A Critical and Historical Commentary on the Bible. Minneapolis: Fortress, 2007.

Collins, Raymond F. Divorce in the New Testament. Collegeville, MN: Liturgical, 1992. . Sexual Ethics in the New Testament: Behavior and Belief. New York: Crossroad Publishing, 2000.

Colson, Francis Henry, and George Herbert Whitaker, trans. Philo. Loeb Classical Library. 10 vols. Cambridge: Harvard University Press, 1968.

Conzelmann, Hans. An Outline of the Theology of the New Testament. Translated by John Bowden. New York: Harper \& Row, 1969.

. The Theology of St. Luke. Translated by Geoffrey Buswell. New York: Harper, 1960.

Cook, Michael J. Mark's Treatment of the Jewish Leaders. Supplement to Novum Testamentum 51. Leiden: Brill, 1979.

Corbett, Percy Elwood. Roman Law of Marriage. 1930. Reprint, Aalen, Germany: Scientia Verlag, 1979.

Cornell, Timothy J. The Beginnings of Rome: Italy and Rome from the Bronze Age to the Punic Wars: c. 1000-264 BC. New York: Routledge, 1995.

Cornes, Andrew. Divorce and Remarriage: Biblical Principles and Pastoral Care. Grand Rapids, MI: Eerdmans, 1993.

Cowley, Arthur Ernest, ed. Aramaic Papyri of the Fifth Century B. C. Oxford: Clarendon, 1923.

Cranfield, Charles E. B. The Gospel according to St. Mark. Cambridge Greek Testament Commentary. Edited by Charles F. D. Moule. Cambridge: Cambridge University Press, 1959.

Creed, John M. The Gospel according to St. Luke. London: Macmillan, 1957.

Crouzel, Henri. "Divorce and Remarriage in the Early Church: A Propos of a Recent Book." Irish Theological Quarterly 38 (1971): 21-41.

. L'église primitive face au divorce du oremier cinquième siècle. Paris: Beauchesne, 1971. 
Crouzel, Henri. "Le texte patristique de Matthieu v.32 et xix.9." New Testament Studies 19 (October 1972): 98-119.

Danby, Herbert, trans. The Mishnah. London: Oxford University Press, 1983.

Daube, David. "Concessions to Sinfulness in Jewish Law." Journal for Jewish Studies 10 (1959): 1-13. . The New Testament and Rabbinic Judaism. New York: Arno Press, 1973. ."The New Testament Terms for Divorce." Theology 47 (1944): 65-67.

Davidson, Richard M. Flame of Yahweh: Sexuality in the Old Testament. Peabody, MA: Hendrickson, 2007.

. "Divorce and Remarriage in the Old Testament: A Fresh Look at Deuteronomy 24:1-4." Journal of the Adventist Theological Society 10, no. 1-2 (1999): 2-22.

Davies, W. D. The Setting of the Sermon on the Mount. Cambridge: University Press, 1964.

Davies, W. D., and Dale C. Allison. A Critical and Exegetical Commentary on the Gospel according to Saint Matthew. International Critical Commentary. 3 vols. Edingburgh: T. \& T. Clark, 1988/1997.

De la Brosse, Olivier, Antonin-Marie Henry, and Philippe Rouillard, eds. Dictionnaire de la foi chrétienne. 2 vols. Paris: de Cerf, 1968.

De Reeper, J. "Marriage and Divorce in Present-day Theology." Anglican Ecclesial Review 16 (1974): 389-400.

Decker, John W. "Marriage and Divorce in the Early Christian Church.” Ph.D. diss., Southern Baptist Theological Seminary, 1917.

Declareuil, Joseph. Rome, the Law-Giver. New York: Alfred A. Knopf, 1927.

Derrenbacker, R. A. Ancient Compositional Practices and the Synoptic Problem. Dudley, MA: Peeters, 2005.

De Zamoras, Juan Alfonso. Los nueve libros de valerio máximo as Contained in BNM MS. 2208. CD-ROM, no. 8. Madison, WI: Hispanic Seminary of Medieval Studies, 1999.

Derrett, J. Duncan M. Law in the New Testament. London: Darton, Longman \& Todd, 1970.

Dibelius, Martin. From Tradition to Gospel. New York: Charles Scribner, 1965. 
Dibelius, Martin. Gospel Criticism and Christology. London: Ivor Hicholson \& Watson, 1935.

Dictionnaire de la foi chrétienne. Edited by Olivier de la Brosse, Antonin-Marie Henry, and Philippe Rouillard. Paris: de Cerf, 1968.

Diderichsen, Børge Krag. Den markianske skilmisserpericope: Dens genesis or historike placering. Gyldendal: Aarhuus Stiftsbogtrykkeril, 1962.

Dio, Cassius. Roman History. Translated by Earnest Cary. Loeb Classical Library. 9 vols. New York: Putnam, 1925.

Dionysius. Roman Antiquities. Translated by Earnest Cary. Loeb Classical Library. 7 vols. Cambridge: Harvard University Press, 1937.

Dixon, Suzanne. The Roman Family. Baltimore: Johns Hopkins University Press, 1992.

Dodd, Charles Harold. The Interpretation of the Fourth Gospel. Cambridge: University Press, 1953.

Donahue, John R. "Windows and Mirrors: The Setting of Mark's Gospel." Catholic Biblical Quarterly 57 (1995): 1-26.

The Douay-Rheims American Edition. Hermeneutika 7.0. 1899.

Down, Michael J. “The Sayings of Jesus about Marriage and Divorce." Expository Times 95 (1984): 332-334.

Dungan, David L. A History of the Synoptic Problem: The Canon, the Context, the Composition, and the Interpretation of the Gospels. Anchor Bible Reference Library. 19 vols. Edited by David N. Freedman. New York: Doubleday, 1999. . The Sayings of Jesus in the Churches of Paul. Philadelphia: Fortress, 1971. . "Theory of Synopsis Construction." Biblica 61 (1980): 305-329.

Du Plessis, I. Johannes. "The Ethics of Marriage according to Matt 5:27-32.” Neotestamentica 1 (1967): 16-27.

Edwards, James R. The Gospel according to Mark. Grand Rapids, MI: Eerdmans, 2002.

Ehrman, Bart D., trans. The Apostolic Fathers. Loeb Classical Library. 2 vols. Cambridge: Harvard University Press, 2003.

Ellingworth, Paul. "Text and Context in Mark 10:2, 10." Journal for the Study of the New Testament 5 (1979): 63-66.

Elliot, James Keith. The Language and Style of the Gospel of Mark. Supplements to Novum Testamentum 71. Leiden: Brill, 1993. 
Elliot, James Keith. "Paul's Teaching on Marriage in 1 Corinthians: Some Problems Considered." New Testament Studies 19 (1973): 219-225.

Encyclopedia Judaica. Translated by Cecil Roth. New York: Macmillan, 1971-1972.

England, Harold Ray. "Divorce and Remarriage in 1 Corinthians 7:10-16." Ph.D. diss., Southern Baptist Theological Seminary, 1982.

Epstein, Claire. "Hippos (Sussita)." The New Encyclopedia of Archaeological Excavations in the Holy Land. Edited by Ephraim Stern. Jerusalem: Israel Exploration Society, 1993. 2:33-37.

Epstein, Isidore, ed. The Babylonian Talmud. 8 vols. London: Soncino Press, 1935-1948.

Epstein, Louis M. The Jewish Marriage Contract: A Study in the Status of the Woman in Jewish Law. New York: Arno Press, 1973.

Esmein, Adhémar. Mélanges d'histoire du droit et de critique: Droit Romain. 1886. Reprint, Aalen, Germany: Scientia Verlag, 1970.

Ernst, Joseph. Das evangelium nach Markus. Regensburg: Friedrich Pustet, 1981.

Etheridge, John Wesley, trans. The Targum of Onkelos and Jonathan ben Uzziel on the Pentateuch. London: Longman, Green, Longman, Roberts, and Green, 1951.

Euripides. The Fragments. Edited and translated by David Kovacs. 8 vols. Cambridge, MA: Harvard University Press, 1994-.

Falk, Ze'ev W. The Divorce Action by the Wife in Jewish Law. Jerusalem: Hebrew University, 1973. . Hebrew Law in Biblical Times. Jerusalem: Wahrmann, 1964.

Fantham, Elaine. Julia August: The Emperor's Daughter; Women in the Ancient World. New York: Routledge, 2006.

Fee, Gordon D. The First Epistle to the Corinthians. New International Commentary of the New Testament. Grand Rapids. MI: Eerdmans, 1991. . New Testament Exegesis: A Handbook for Students and Pastors. 3rd ed. Louisville, KY: Westminster John Knox, 2002.

Feine, Paul, and Johannes Behm. Introduction to the New Testament. 14th rev. ed. Translated by A. J. Matill, Jr. Edited by Werner G. Kümmel. Nashville, TN: Abingdon, 1966.

Feldman, Louis H. "How Much Hellenism in Jewish Palestine?" Hebrew Union College Annual 57 (1986): 95. 
Festugière, André Jean, trans. Corpus hermeticum. 4 vols. Paris: Societé D’Édition Les Belles Lettres, 1954-1960.

Filson, Floyd V. A Commentary on the Gospel according to St. Matthew. New York: Harper \& Brother, 1960.

Fine, Steven, ed. Jews, Christians, and Polytheists in the Ancient Synagogue: Cultural Interaction during the Greco-Roman Period. London: Routledge, 1999.

Finkelstein, Louis. The Pharisees. 3rd ed. Philadelphia: Jewish Publication Society of America, 1938.

Fischer, James A. "1 Cor 7:8-24: Marriage and Divorce." Journal of the Chicago Society of Biblical Research 23 (1978): 33.

Fishbane, Michael. Biblical Interpretation in Ancient Israel. Oxford: Clarendon, 1986.

Fitzmyer, Joseph A. The Gospel according to Luke. Anchor Bible Reference Library. 28 vols. New York: Doubleday, 1981.

. "The Matthean Divorce Texts and Some New Palestinian Evidence." Theological Studies 37 (1976): 108-115; 197-226.

Fleming, Thomas V. “Christ and Divorce.” Theological Studies 1 (1963): 106-120.

Flusser, David. Judaism of the Second Temple Period. Translated by Azzan Yadin. Grand Rapids, MI: Eerdmans, 2007.

Fowler, William Warde. Social Life at Rome. Chautauqua, NY: Chautauqua Press, 1909.

Freedman, David Noel, ed. Eerdmans Dictionary of the Bible. Grand Rapids, MI: Eerdmans, 2000.

Freyne, Séan. "Christianity in Sepphoris and in Galilee." In Galilee and the Gospels: Collected Essays, 299-307. Tübingen: Mohr Siebeck, 2000.

. "The Galileans in the Light of Josephus' Life." In Galilee and the Gospels: Collected Essays, 27-44. Tübingen: Mohr Siebeck, 2000. . Galilee and the Gospels: Collected Essays. Tübingen: Mohr Siebeck, 2000.

. Galilee from Alexander the Great to Hadrian: 323 B.C.E. to 135 C.E. Notre Dame, IN: University of Notre Dame Press, 1980.

. Galilee, Jesus, and the Gospels: Literary Approaches and Historical Investigations. Philadelphia: Fortress, 1988. 
Freyne, Séan. “Town and Country Once More: The Case of Roman Galilee.” In Galilee and the Gospels: Collected Essays, 59-72. Tübingen: Mohr Siebeck, 2000.

Friedlander, Ludwig. Roman Life and Manners under the Early Empire. New York: E. P. Hutton, 1908.

Friedman, Mordechai A. Jewish Marriage in Palestine: A Cairo Geniza Study. 2 vols. New York: Jewish Theological Society of America, 1980.

. "Termination of the Marriage upon the Wife's Request: A Palestinian Ketubba Stipulation." Proceedings of the American Academy of Jewish Research 37 (1969): 29-55.

Früchtel, Ludwig, ed. Clemens Alexandrinus. 3 vols. Berlin: Akademie, 1969-1970.

Fuller, Reginald Horace. A Critical Introduction to the New Testament. London: G. Duckworth, 1966.

Funk, Robert W., Roy W. Hoover, and The Jesus Seminar, trans. The Five Gospels: The Search for the Authentic Words of Jesus. New York: Macmillan, 1993.

Gane, Roy. "Old Testament Principles Relevant to Divorce and Remarriage." Journal of the Adventist Theological Society 12, no. 2 (Autumn 2001): 35-61.

García, Martínez, Florentino, trans. The Dead Sea Scrolls Translated. San Francisco: HarperSanFrancisco, 1996.

Gardner, Jane F. Women in Roman Law and Society. London: Croom-Helm, 1987.

Garrett, Susan R. The Temptations of Jesus in Mark's Gospel. Grand Rapids, MI: Eerdmans, 1998.

Gellius, Aulus. The Attic Nights of Aulus Gellius. Translated by John C. Rolfe. Loeb Classical Library. 3 vols. New York: Putnam, 1927.

The Geneva Bible: The Annotated New Testament. Edited by Gerald T. Sheppard. 1602. Reprint, New York: Pilgrim, 1989.

Gerke, Leonard F. Christian Marriage: A Permanent Sacrament. Washington, DC: Catholic University Press, 1965.

Gibson, Jeffrey B. The Temptations of Jesus in Early Christianity. London: T \& T Clark, 2004.

Girard, Paul Frédéric. Mélanges de droit Romain. Paris: I. Larose \& L. Tenin, 1923.

Glare, P. G. W., ed. Oxford Latin Dictionary. Oxford: Clarendon, 1982. 
Goodacre, Mark S. The Synoptic Problem: A Way through the Maze. London: Sheffield Academic Press, 2001.

Goodenough, E. R. Jewish Symbols in the Greco-Roman World. 13 vols. Princeton: Princeton University Press, 1953-1968.

Goodman, Martin, ed. Jews in a Graeco-Roman World. New York: Oxford University Press, 1998.

Goody, Jack. The Development of the Family and Marriage in Europe. Cambridge: Cambridge University Press, 1983.

Goulder, Michael D. Midrash and Lexicon in Matthew. London: Society for Promoting Christian Knowledge, 1974.

Grabbe, Lester L. A History of the Jews and Judaism in the Second Temple Period. London: T \& T Clark, 2004.

Graf, David Frank. Rome and the Arabian Frontier: From the Nabateans to the Saracens. Brookfield, VT: Ashgate, 1997.

Grant, Frederick Clifton. "The Mind of Christ in Marriage.” In Five Essays on Marriage, edited by Burton Scott Easton, 33-79. 1923. Reprint, Louisville, KY: Cloister, 1946.

Green, Barbara. "Jesus' Teaching on Divorce in the Gospel of Mark." Journal for the Study of the New Testament 38 (1990): 67-75.

Grossgerge, Walther. "Perigamon." In De Senecae et Theosphrasti libris de matrimonio, 55-63. Regimonti: Ex Officina Kuemmeliana, 1911.

Guelich, Robert A. Mark 1-8:26. Word Biblical Commentary 34A. Dallas, TX: Word Books, 1989.

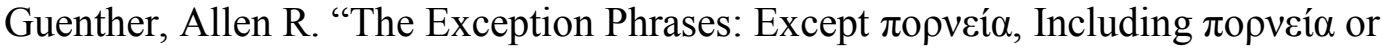
Excluding $\pi$ opveía? (Matthew 5:32; 19:9)." Tyndale Bulletin 53 (2002): 83-96.

Gundry, Robert Horton. Matthew: A Commentary on His Handbook for a Mixed Church under Persecution. Grand Rapids, MI: Eerdmans, 1994.

. Mark: A Commentary on His Apology for the Cross. Grand Rapids, MI: Eerdmans, 1993.

Guthrie, Donald. New Testament Introduction. 4th ed. Downers Grove, IL: InterVarsity, 1990.

Haenchen, Earnest. The Acts of the Apostles: A Commentary. Translated by Robert M. Wilson. Philadelphia: Westminster, 1971. 
Hagner, D. A. The Jewish Reclamation of Jesus. Grand Rapids, MI: Zondervan, 1984.

Haines, Charles Reginald, trans. The Communings with Himself of Marcus Aurelius Antonius, Emperor of Rome. Loeb Classical Library. Cambridge, MA: Harvard University Press, 1961.

Hall, Stuart George, ed. Melito of Sardis. Oxford: Clarendon, 1979.

Hallet, Judith P. "The Role of Women in Elegy: Counter-Cultural Feminism." In Women in the Ancient World: The Arethusa Papers, edited by John Peradotto and J. P. Sullivan, 241-262. Albany: State University of New York Press, 1984.

Hamerton-Kelly, Robert. God the Father: Theology and Patriarchy in the Teaching of Jesus. Philadelphia: Fortress, 1979.

Hammond, Nicholas Geoffrey Lempriere, and Howard Hayes Scullard, eds. The Oxford Classical Dictionary. 2nd ed. Oxford: Clarendon, 1970.

Harrell, Pat Edwin. Divorce and Remarriage in the Early Church: A History of Divorce and Remarriage in the Ante-Nicene Church. Austin, TX: Sweet, 1967.

Harrington, Wilfred. “Jesus' Attitude towards Divorce.” Irish Theological Quarterly 27 (1970): 200.

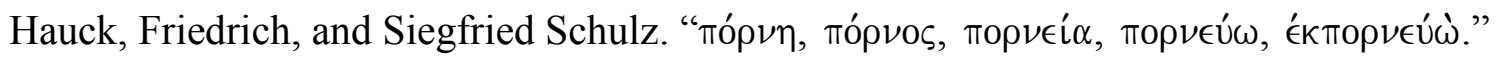
Theological Dictionary of the New Testament. Edited by Gerhard Friedrich. Translated by Geoffrey Bromiley. Grand Rapids, MI: Eerdmans, 1964-1976.

Hays, Richard B. The Moral Vision of the New Testament: A Contemporary Introduction to New Testament Ethics. San Francisco: HarperSanFrancisco, 1996.

Head, Peter M. Christology and the Synoptic Problem: An Argument for Markan Priority. New York: Cambridge University Press, 1997.

Healy, Mary. The Gospel of Mark. Edited by Peter S. Williamson and Mary Healy. Grand Rapids, MI: Baker Academic, 2008.

Heaton, Eric William. Everyday Life in OT Times. New York: Charles Scribner's Sons, 1956.

Heger, Paul. "Preference for Individual Opinion.” In The Pluralistic Halakah: Legal Innovations in the Second Commonwealth and Rabbinic Periods, 187-199. Berlin: Walter de Gruyter, 2003.

Heger, Paul. The Pluralistic Halakhah. New York: De Gruyter, 2010. 
Hengel, Martin. Jews, Greeks, and Barbarians: Aspects of the Hellenization of Judaism in the Pre-Christian Period. Translated by John Bowden. Philadelphia: Fortress, 1980.

. "Judaism and Hellenism in Retrospect." Journal of Biblical Literature 96 (1977): 371-382.

. Judaism and Hellenism: Studies in Their Encounter with Palestine during the Early Hellenistic Period. 2 vols. Translated by John Bowden. London: SCM Press, 1974.

. Studies in the Gospel of Mark. Philadelphia: Fortress, 1985.

Hermeneutika BibleWorks 8.0. Big Fork, MT: Author, 2010.

Herron, Robert W. "Mark's Jesus on Divorce: Mark 10:1-12 Reconsidered.” Journal of the Evangelical Theological Society 25 (1982): 273-281.

Hersch, Karen K. The Roman Wedding: Ritual and Meaning in Antiquity. Cambridge: Cambridge University Press, 2010.

Heth, William. "Jesus on Divorce: How My Mind Set Has Changed." Southern Baptist Journal of Theology 6 (Spring 2002): 4-29.

Heth, William A., and Gordon J. Wenham. Jesus and Divorce: The Problem of the Evangelical Consensus. Nashville, TN: Nelson, 1985.

Hezser, Catherine. The Social Structure of the Rabbinic Movement in Roman Palestine. Tübingen: Mohr Siebeck, 1997.

Hidary, Richard. "Tolerance for Diversity in Halakhic Practice in the Talmud." Ph.D. diss., New York University, 2008.

Hiers, Richard H. The Kingdom of God in the Synoptic Tradition. Gainesville: University of Florida Press, 1970.

Himes, Kenneth R., and James A. Coriden. "The Indissolubility of Marriage: Reasons to Reconsider.” Theological Studies 65 (2004): 453-499.

Hirth, Oscar H. "Interpretation in the Gospels: An Examination of the Use of Redaction Criticism in Mark 8:27-9:32 (Par. Matthew 16:13-17:23; Luke 9:18-45).” Th.D. diss., Dallas Theological Seminary, 1985.

Hoehner, Harold, W. Herod Antipas. Grand Rapids, MI: Zondervan, 1980.

Holmes, Michael W., ed. The Apostolic Fathers: Greek Texts and English Translations. Grand Rapids, MI: Baker, 1999. 
Holwerda, David C. "Jesus on Divorce: An Assessment of a New Proposal." Calvin Theological Journal 22 (1987): 114-120.

The Holy Bible from Ancient Eastern Manuscripts containing the Old and New Testaments. Translated by George M. Lamsa. Philadelphia: A. J. Holman, 1967.

Hooker, Morna Dorothy. The Gospel according to St. Mark. London: A \& C Black, 1991.

Hopkins, M. K. “The Age of Roman Girls.” Population Studies 18 (1965): 309-327.

House, Hershel Wayne. "Divorce and Remarriage under a Variety of Circumstances: Responses.” In Divorce and Remarriage: Four Christian Views, 231-248. Downers Grove, IL: InterVarsity, 1990. . "An Investigation of the New Testament Teaching on Divorce and Remarriage from a Biblical-Historical Perspective." Th.M. thesis, Western Conservative Baptist Seminary, 1974.

Hultgren, Stephen. Narrative Elements in the Double Tradition: A Study of Their Place within the Framework of the Gospel Narrative. New York: Walter De Gruyter, 2002.

Humbert, Michel. Le remariage à Rome: Etude d'histoire juridique et sociale. Milan: Giuffrè, 1972.

Hummel, Reinhart. Die auseinandersetzung zwischen kirche und judentum im Matthäusevangelium. Munich: Chr. Kaiser, 1966.

Hunt, Arthur S., ed., and C. C. Edgar, trans. Select Papyri. 2 vols. New York, Putnam, 1932-1934.

Instone-Brewer, David. "1 Corinthians 7 in the Light of the Graeco-Roman Marriage and Divorce Papyri." Tyndale Bulletin 52, no. 1 (2001): 101-115.

. "1 Corinthians 7 in the Light of the Jewish, Greek and Aramaic Marriage and Divorce Papyri." Tyndale Bulletin 52, no. 2 (2001): 225-243.

. "Four Biblical Grounds for Divorce." In Divorce and Remarriage in the Church: Biblical Solutions for Pastoral Realities, 93-106. Downers Grove, IL: IVP Books, 2003.

. "Greek, Aramaic, and Latin Marriage and Divorce Papyri." www.tyndale. cam.ac.uk/Brewer/marriagepapyri/ (accessed September 18, 2011).

. "Jesus' Teaching: Divorce on Biblical Grounds Only." In Divorce and Remarriage in the Bible: The Social and Literary Context, 133-188. Grand Rapids, MI: Eerdmans, 2002. 
Instone-Brewer, David. "Jewish Women Divorcing Their Husbands in Early Judaism: The Background to Papyrus Se'elim 13." Harvard Theological Review 92 (July 1999): 349-357.

. "Rabbinic Teaching: Increasing Grounds for Divorce." In Divorce and Remarriage in the Bible: The Social and Literary Context, 85-132. Grand Rapids, MI: William B. Eerdmans, 2002.

. "What God Has Joined Together: What Does the Bible Really Teach about Divorce?" Christianity Today, October 1, 2007, 26-29.

Isaeus. Isaeus. Edited by Edward Seymour Forster. Cambridge, MA: Harvard University Press, 1957.

Isaksson, Abel. Marriage and Ministry in the New Temple. Lund, Sweden: C. W. K Gleerup, 1965.

Iverson, Kelly R. Gentiles in the Gospel of Mark. Library of New Testament Studies [formerly JSNT Supplement Series] 339. New York: T \& T Clark, 2007.

Jackson, Bernard S. Essays in Jewish and Comparative Legal History. Leiden: Brill, 1975.

Jacobs-Malina, Diane. Beyond Patriarchy: The Images of Family in Jesus. New York: Paulist Press, 1993.

Jagu, Amand, trans. Musonius Rufus. New York: G. Olms, 1979.

James, Montague Rhodes, trans. The Apocryphal Books of the New Testament. Philadelphia: David McKay, 1901. . The Apocryphal New Testament. Oxford: Clarendon, 1924.

Janzen, David. "The Meaning of Porneia in Matthew 5:32 and 19:9: An Approach from the Study of Ancient Near Eastern Culture." Journal for the Study of the New Testament 80 (2000): 66-80.

Jastrow, Marcus. A Dictionary of the Targum, the Talmud Babli and Yerushalmi and the Midrashic Literature. New York: Title Publishing House, 1943.

Jeffers, James S. The Greco-Roma World of the New Testament Era. Downers Grove, IL: InterVarsity, 1999.

Jepson, John J., trans. "St. Augustine: The Lord's Sermon on the Mount.” In Ancient Christian Writers, Vol. 5. Westminster, MD: Newman, 1948.

Jeremias, Joachim. Jerusalem in the Time of Jesus. Translated by F. H. Cave and C. H. Cave. Philadelphia: Fortress, 1969. 
Jeremias, Joachim. New Testament Theology. 2 vols. New York: Scribner, 1971. . Teología del nuevo testamento. Salamanca: Sígueme, 1980.

Jewett, Paul K. Man as Male and Female: A Study in Sexual Relationships from a Theological Point of View. Grand Rapids, MI: Eerdmans, 1975.

Johnson, S. E. A Commentary on the Gospel according to Mark. New York: Harper, 1960.

Johnson, W. H. "The Sister-in-law of Cicero.” Cambridge Journals (1913): 160-165.

Johnston, Robert M. "Unfaithfulness to the Marriage Vow." Ministry, November 1994, 14-16.

Jolowicz, Herbert Felix. Historical Introduction to the Study of Roman Law. 1932. Reprint, Holmes Beach, FL: Wm. W. Gaunt, 1996.

Jones, David W. "The Betrothal View of Divorce and Remarriage." Bibliotheca Sacra 165 (January-March 2008): 68-85.

Josephus, Flavius. Josephus. Translated by Henry St. John Thackeray, Ralph Marcus, Allen Paul Wikgren, and Louis H. Feldman. Loeb Classical Library. 9 vols. New York: Putnam, 1926-1965.

. The Works of Josephus: Complete and Unabridged. Translated by William Whiston. Rev. ed. Peabody, MA: Hendrickson, 1988.

Joyce, George Hayward. Christian Marriage: An Historical and Doctrinal Study. 2nd ed. London: Sheed \& Ward, 1948.

Juvenalis, Decimus, and Allus Persius. Juvenal and Persius. Translated by George Gilbert Ramsay. Loeb Classical Library. Cambridge: Harvard University Press, 1950.

Karlowa, Otto. Römische rechtsgeschichte. Leipzig: Veit, 1901.

Karnetzki, Manfred. "Die galiläische redaktion im markusevangelium." Zeitschrift für die neutestamentliche Wissenschaft und die Kunde der älteren Kirche 52 (1961): 246247.

Kasher, Aryeh. Jews and Hellenistic Cities in Eretz-Israel: Relations of the Jews in Eretz-Israel with Hellenistic Cities during the Second Temple Period 332 BCE-70 CE. Tübingen: J. C. B. Mohr, 1990.

Kee, Howard C. Community of the New Age: Studies in Mark's Gospel. Philadelphia: Westminster, 1977. 
Keenan, John P. The Gospel of Mark: A Mahayana Reading. Maryknoll, NY: Orbis Press, 1995.

Keener, Craig. And Marries Another: Divorce and Remarriage in the Teaching of the New Testament. Peabody, MA: Hendrickson, 1991.

Kelber, Werner H. The Kingdom in Mark: A New Place and a New Time. Philadelphia: Fortress, 1974.

Kernaghan, Ronald J. Mark. Downers Grove, IL: InterVarsity Press, 2007.

Kissinger, Warren S. The Lives of Jesus: History and Bibliography. New York: Garland, 1985.

Kitchin, Shepherd Braithwaite. A History of Divorce. London: Chapman Hall, 1912.

Klausner, Joseph. Jesus of Nazareth: His Life, Times, and Teaching. 1925. Translated by Herbert Danby. Reprint, New York: Macmillan, 1964.

Koester, Helmut. "History and Development of Mark's Gospel." In Colloquy on New Testament Studies, edited by Bruce Corley, 62-63. Macon, GA: Mercer University Press, 1983.

Krabel, A. T. "Social Systems of Six Diaspora Synagogues." In Ancient Synagogues: The State of Research, edited by Joseph Gutmann, 79-91. Brown Judaic Studies 22. Chico, CA: Scholars Press, 1981.

Kroeger, Rolf O. "Pericope." The International Standard Bible Encyclopedia. Edited by Geoffrey W. Bromiley. Grand Rapids, MI: Zondervan, 1991. 3:770.

Kudasiewics, Joseph. The Synoptic Gospels Today. Translated by Sergius Wroblewski. New York: Alba House, 1996.

Ladd, George Eldon. The Gospel of the Kingdom. London: Paternoster, 1959.

Laetch, Theodore. "Divorce and Malicious Desertion." Concordia Theological Monthly 4 (1933): 128.

Lagrange, Marie Joseph. "L’Évangile de Saint Marc n'a pas été écrit en Latin." Revue Biblique 37 (1928): 114.

Lake, Kirsopp. The Apostolic Fathers. Loeb Classical Library. 2 vols. Cambridge: Harvard University Press, 1948.

. “The Earliest Christian Teaching on Divorce.” Expositor 10 (1910): 416-427.

Lane, William L. The Gospel according to Mark. New International Commentary on the New Testament. Grand Rapids, MI: Eerdmans, 1974. 
Laney, Carl J. "Divorce and the Christian Ministry (1 Tim. 3:2, 12 and Titus 1:6)." In The Divorce Myth, 91-102. Minneapolis: Bethany House, 1981.

Launspach, Charles W. L. State and Family in Early Rome. London: George Bell and Sons, 1908.

Lee, Bernard J. The Galilean Jewishness of Jesus: Retrieving the Jewish Origins of Christianity. New York: Paulist Press, 1988.

Lefkowitz, Mary R., and Maureen B. Fant. Women in Greece and Rome. Baltimore: Johns Hopkins University Press, 1982.

Leggett, Donald A. The Levirate and Goel Institutions in the Old Testament: With Special Attention to the Book of Ruth. Cherry Hill, NJ: Mack, 1974.

Lehmann, Manfred R. "Gen 2:24 as the Basis for Divorce in Halakhah and New Testament." Zeitschrift für die alttestamentliche Wissenschaft 72 (1960): 263-267.

Lenski, Richard C. H. The Interpretation of St. Matthew's Gospel. Minneapolis: Augsburg, 1961.

Lévy-Bruhl, Henri. "Les origines du mariage sine manu." Tijdschrift voor Rechtsgeschiedenis 14 (1936): 453.

Lichtenberger, Achim. Kulte und kultur der Dekapolis: Untersuchungen zu numismatischen, archäologischen und epigraphischen zeugnissen. Abhandlungen des deutschen Palästina-Vereins. Band 29. Wiesbaden: Harrassowitz Verlag, 2003.

Lieberman, Saul. Greek in Jewish Palestine. New York: Jewish Theological Seminary of America, 1994.

Lightfoot, J. B., and J. R. Harmer, trans. The Apostolic Fathers. 2nd ed. Edited by Michael W. Holmes. Grand Rapids, MI: Baker, 1989.

Lightfoot, Robert Henry. Locality and Doctrine in the Gospels. New York: Harper and Brother, 1938.

Lim, Johnson. "Divorce and Remarriage in Theological and Contemporary Perspectives." Asia Journal of Theology 20 (2006): 271-284.

Lindars, Barnabas. New Testament Apologists: The Doctrinal Significance of O.T. Quotations. Philadelphia: Westminster, 1961.

Livius, Titus. Livy. Translated by Benjamin Oliver Foster. Loeb Classical Library. 3 vols. Cambridge: Harvard University Press, 1939-1951. 
Livius, Titus. Livy. Translated by Evan T. Sage. Loeb Classical Library. 9 vols. Cambridge: Harvard University Press, 1935-1947.

Lohmeyer, Ernest. Das evangelium des Markus. Göttingen: Vandenhoeck \& Ruprecht, 1963. . Galiläa und Jerusalem. Göttingen: Vandenhoeck \& Ruprecht, 1936.

Long, George, trans. The Discourses of Epictetus. New York: A. L. Hurt, 1878.

Longstaff, Thomas R. W. "Nazareth and Sepphoris: Insights into Christian Origins." Anglican Theological Review Supplement 11 (1990): 8-15.

Lövestam, Evald. "Divorce and Remarriage in the New Testament." In The Jewish Law Annual, edited by B. S. Jackson, 4:47-65. Leiden: Brill, 1981.

Luck, William F. Divorce and Remarriage: Recovering the Biblical View. San Francisco: Harper \& Row, 1987.

Luckock, Herbert Mortimer. The History of Marriage, Jewish and Christian, in Relation to Divorce and Certain Forbidden Decrees. New York: Longmans, Green \& Co., 1895.

Luke, Helen M. “The Marriage Vow.” Parabola 29 (Spring 2004): 49-51.

Lundström, Gösta. The Kingdom of God in the Teaching of Jesus. Translated by Joan Bulman. Richmond, VA: John Knox Press, 1963.

Luther, Martin. “The Babylonian Captivity of the Church.” Luther's Works, 36:11-57. American ed. Edited by Jaroslav Pelikan and Helmut T. Lehmann. St. Louis, MO: Concordia, 1955-1976.

Maccoby, H. The Mythmaker: Paul and the Invention of Christianity. London: Weidenfeld \& Nicholson, 1986.

MacCormack, G. “Coemptio and Marriage by Purchase." Bulletino dell'Istituto di Diritto Romano 81 (1978): 179-199.

MacLennan, John F. Primitive Marriage: An Inquiry into the Origin of the Form of Capture in Marriage Ceremonies. Chicago: University of Chicago Press, 1970.

Mahoney, Aidan. "A New Look at the Divorce Clauses in Matt 5,32 and 19,9." Catholic Biblical Quarterly 30 (1968): 29-38.

Maier, Paul L., trans. Eusebius: The Church History. Grand Rapids, MI: Kregel, 1999.

Major, Henry D. A., Thomas W. Manson, and C. J. Wright. The Mission and Message of Jesus: An Exposition of the Gospels in the Light of Modern Research. New York: E.P. Dutton, 1938. 
Manek, Jindrich. "Mark viii 14-21.” Novum Testamentum 7 (1964-1966): 10-17.

Mann, Christopher Stephen. Mark. Anchor Bible Reference Library. 28 vols. Edited by David Noel Freedman and William Fox Albright. Garden City, NY: Doubleday, 1986.

Manson, Thomas Walter. Studies in the Gospels. Manchester: Manchester University Press, 1962. . The Teachings of Jesus. Cambridge: Cambridge University Press, 1951.

Mantel, Hugo. Studies in the History of the Sanhedrin. Cambridge: Harvard University Press, 1965.

Marcel, Simon. Jewish Sects at the Time of Jesus. Translated by James H. Farley. Philadelphia: Fortress, 1967.

Marcus, Joel. "The Jewish War and the Sitz im Leben of Mark." Journal of Biblical Literature 111 (1992): 441-462. . Mark 1-8: A New Translation with Introduction and Commentary. New York: Doubleday, 2000.

. Mark 8-16: A New Translation with Introduction and Commentary. New Haven, CT: Yale University Press, 2009. . The Mystery of the Kingdom of God. Atlanta: Scholars Press, 1986.

Mare, Harold W. "Decapolis." Eerdmans Dictionary of the Bible. Edited by David Noel Freedman. Grand Rapids, MI: Eerdmans, 2000. 44.

Marrow, Stanley B. "Marriage and Divorce in the New Testament." Anglican Theological Review 70 (1988): 3-15.

Marshall, I. Howard, and W. Ward Gasque, eds. The Gospel of Luke: A Commentary on the Greek Text. New International Greek Testament Commentary. Grand Rapids, MI: Eerdmans, 1978.

Martial, Marcus Valerius. Epigrams. Translated by D. R. Shackleton Bailey. Loeb Classical Library. 3 vols. Cambridge: Harvard University Press, 1993.

Martin, Ralph P. Mark: Evangelist and Theologian. London: Paternoster, 1972.

Martínez, Florentino García, trans. The Dead Sea Scrolls Translated. San Francisco: HarperSanFrancisco, 1996.

Marxsen, Willi. Introduction to the New Testament. Translated by G. Buswell. Philadelphia: Fortress, 1968. 
Marxsen, Willi. Mark the Evangelist. Translated by James Boyce, Donald Juel, William Poehlmann, and Roy A. Harrisville. New York: Abingdon, 1969.

Maximus, Valerius. Electronic Text and Concordences of Juan Alfonso de Zamoras Spanish Translation of Los Nueve Libros de Valerio Máximo as Contained in BNM MS. 2208. Madison, WI: Hispanic Seminary of Medieval Studies, 1999.

Mayo, Fulata. "Can Divorce Be a Solution to Marital Problems in a Christian Marriage?" Ecumenical Review 56, no. 4 (October 2004): 437-447.

McCarthy, David Matzko. Becoming One Flesh: Marriage, Remarriage, and Sex. Malden, MA: Oxford University Press, 2004.

McFadden, Dennis E. “Just What Did Jesus Say about Divorce?” Christianity Today, November 20, 1981, n.p.

McKnight, Edgar V. Jesus Christ Today: The Historical Shaping of Jesus for the TwentyFirst Century. Macon, GA; Mercer University Press, 2009.

. What Is Form Criticism? Philadelphia: Fortress, 1969.

McKnight, Scot. Interpreting the Synoptic Gospels. Grand Rapids, MI: Baker, 1988.

Meier, John P. Law and History in Matthew's Gospel: A Redactional Study of Matt 5:1748. Rome: Biblical Institute Press, 1976.

. Law and Love. Vol. 4 of A Marginal Jew: A Rethinking the Historical Jesus. Anchor Bible Reference Library. New Haven, CT: Yale University Press, 2009. . A Marginal Jew: Rethinking the Historical Jesus. New York: Doubleday, 1991.

Merkel, Helmut. “Jesus und die Pharisäer.” New Testament Studies 14 (1968): 194-208.

Metzger, Bruce M. A Textual Commentary on the Greek New Testament. New York: United Bible Societies, 1971.

Meyers, Eric M. “Artistry in Stone: The Mosaics of Ancient Sepphoris.” Biblical Archaeology Review 50 (1987): 223-231.

Meyers, Eric M., Ehud Metzer, and Carol L. Meyers. "Sepphoris: 'Ornament of All Galilee." Biblical Archaeology Review 49 (1986): 4-19.

Meyers, Eric M., and James F. Strange. Archaeology, the Rabbis, and Early Christianity. Nashville: Abingdon, 1981.

Millar, Fergus. The Emperor in the Roman World. Ithaca, NY: Cornell University Press, 1977. 
The Modern Reader's Bible: The Books of the Bible with Three Books of the Apocrypha Presented in Modern Literary Form. Edited by Richard G. Moulton. New York: Macmillan, 1940.

Moloney, Francis J. The Gospel of Mark. Peabody, MA: Hendrickson, 2006.

Moltmann, Jürgen. The Way of Jesus Christ. San Francisco: HarperSanFrancisco, 1990.

Morgan, Barry E. "The Synoptic Pericopes Concerning Divorce and Remarriage: An Exegetical and Hermeneutical Study." Ph.D. diss., Southwestern Baptist Theological Seminary, 1987.

Moule, Charles F. D. An Idiom Book of New Testament Greek. 2nd ed. Cambridge: Cambridge University Press, 1959.

Moulton, James H., and George Milligan. The Vocabulary of the Greek Testaments Illustrated from the Papyri and Other Non-literary Sources. London: Hodder and Stoughton, 1952.

Mueller, James, R. "The Temple Scroll and the Gospel Divorce Texts." Revue de Qumran 38 (1980): 255.

Muirhead, James. Law of Rome. London: A \& C Black, 1916.

Mullholland, Robert. “The Markan Opponents of Jesus.” Ph.D. diss., Harvard University, 1977.

Murphy-O’Connor, Jerome. 1 Corinthians. New York: Doubleday, 1998.

. "The Divorced Woman in 1 Corinthians 7:10-11." Journal of Biblical Literature 100 (1981): 602-606.

Murray, John. Divorce. Philadelphia: Orthodox Presbyterian Church, 1953.

Najman, Hindy. "Seconding Sinai: The Development of Mosaic Discourse in Second Temple Judaism." Journal for the Study of Judaism Supplement 77 (2003): 111117.

Neirynck, Frans. Duality in Mark: Contribution to the Study of the Markan Redaction. Bibliotheca ephemeridum theologicarum lovaniensum 31. Rev. ed. Leuven, Belgium: Leuven University Press, 1988.

Neufeld, Edmund. "Marriage after Divorce in Early Judaism.” Didaskalia 1 (1989): 2633.

Neusner, Jacob, trans. The Talmud of the Land of Israel. 26 vols. Chicago: University of Chicago Press, 1982-1994. 
Neusner, Jacob, and William Scott Green, eds. The Pharisees and Other Sects. 2 vols. New York: Garland Publications, 1990.

The New Berkeley Version in Modern English. Edited by Gerrit Verkuyl. Grand Rapids, MI: Zondervan, 1969.

The New Testament: A New Translation in Plain English. Translated by Charles Kingsley Williams. London: SPCK, 1952.

The New Testament in Modern English. Translated by J. B. Phillips. New York: Macmillan, 1972.

The New Testament in the Language of Today. Translated by William F. Beck. St. Louis: Concordia, 1963.

The Newberry Bible. London: Hodder \& Stoughton, 1890.

Nicholas, Barry. An Introduction to Roman Law. Oxford: Oxford University Press, 1962.

Nineham, Dennis. The Gospel of Mark. New York: Seabury, 1963.

Nydam, Ronald J. "The Messiness of Marriage and the Knottiness of Divorce: A Call for a Higher Theology and a Tougher Ethic." Calvin Theological Journal 40, no. 2 (2005): 211-226.

Oepke, Albrecht. " $\gamma \nu \nu \epsilon$." Theological Dictionary of the New Testament. Edited by G. Kittel and G. Friedrich. Translated by G. W. Bromiley. 10 vols. Grand Rapids, MI: Eerdmanns, 1964-1976. 1:778.

Oldfather, William Abbott, trans. The Discourses as Reported by Arrian, the Manual, and Fragments. 2 vols. Cambridge: Harvard University Press, 1928-1946.

O'Leary, Anne M. Matthew's Judaization of Mark. New York: T \& T Clark, 2006.

Olsen, Viggo Norskov. The New Testament Logia on Divorce: A Study of Their Interpretation from Erasmus to Milton. Tübingen: Mohr [Siebeck], 1971.

O’Mahoney, Patrick J. “The Unbreakable Bond.” In Catholics and Divorce, edited by Patrick J. O’Mahoney, 14-31. London: Thomas Nelson \& Sons, 1959.

O’Rourke, John J. “A Note on an Exception: Mt 5:32 (19:9) and 1 Cor 7:12 Compared.” Heythrop Journal 5 (1964): 299-302.

Oulton, Ernest Leonard, and Henry Chadwick. Alexandrian Christianity. Library of Christian Classics. 26 vols. Philadelphia: Westminster, 1954.

Ovid. The Art of Love and Other Poems. Translated by John Henry Mozley. Loeb Classical Library. Cambridge: Harvard University Press, 1962. 
The Oxford Classical Dictionary. Edited by Simon Hornblower and Antony Spawforth. 3rd ed. New York: Oxford University Press, 2003.

Oxford Latin Dictionary. Edited by P. G. W. Glare. 1968. Reprint, New York: Oxford University Press, 1982.

Painter, John. Mark’s Gospel. London: Routledge, 1997.

Pakkala, Juha. Ezra the Scribe: The Development of Ezra 7-10 and Nehemiah 8. New York: Walter de Gruyter, 2004.

Pantelia, Maria C., Project Director. Thesaurus Linguae Graecae. CD ROM no. E. Irvine: University of California, 1999.

Parker, Pierson. "Jesus, John the Baptist, and the Herods." Perspectives in Religious Studies 8 (Spring 1981): 4-11.

Parker, Thomas S. "The Byzantine Period: An Empire's New Holy Land.” Near Eastern Archaeology 62, no. 3 (September 1999): 134-171.

Paton, William Roger, trans. The Greek Anthology. Loeb Classical Library. 5 vols. Cambridge: Harvard University Press, 1939.

Peradotto, John, and J. P. Sullivan, eds. Women in the Ancient World: The Arethusa Papers. Albany, NY: State University of New York Press, 1984.

Perrin, Norman. Rediscovering the Teaching of Jesus. New York: Harper \& Row, 1967.

. "Toward an Interpretation of the Gospel of Mark." In Christology and a Modern Pilgrimage: A Discussion with Norman H. Perrin, edited by D. Betz. Claremont, CA: New Testament Colloquium, 1971.

Perrin, Norman, Dennis C. Duling, and Robert L. Ferm, eds. The New Testament: Proclamation and Paraenesis, Myth and History. 3rd ed. Fort Worth, TX: Harcourt Brace College, 1994.

Perschbacher, Wesley J., ed. The New Analytical Greek Lexicon. Peabody, MA: Hendrickson, 1990.

Pesch, Rudolf. Das markusevangelium. Herders theologischer kommentar zum neuen testament. 2 vols. Freiburg: Herder, 1977.

Philipose, Jonathan. "Western Non-Interpolations and Related Phenomena in the Gospels.” Ph.D. diss., St. Andrews University, 1961.

Philo. Philo with an English Translation. Translated by Francis Henry Colson and George Herbert Whitaker. 10 vols. Loeb Classical Library. 1934. Reprint, Cambridge, MA: Harvard Univesity Press, 1968. 
Philo. The Works of Philo. Translated by C. D. Yonge. Peabody, MA: Hendrickson, 1997.

Plautus. Plautus. Translated by Paul Nixon. Loeb Classical Library. 5 vols. New York: Putnam, 1916-1938.

. T. Macci Plavti Comoediae. Edited by W. M. Lindsay. 2 vols. 1904. Reprint, London: Clarendon, 1966.

Pliny the Elder. Natural History. Translated by Harris Rackham and W. H. S. Jones. Loeb Classical Library. 10 vols. Cambridge: Harvard University Press, 1961-.

Plummer, Alfred. An Exegetical Commentary on the Gospel according to St. Matthew. London: Elliot Stock, 1909.

Plutarch. Plutarch's Lives. Translated by Bernadotte Perrin. Loeb Classical Library. 6 vols. Cambridge: Harvard University Press, 1958-1962.

. Plutarch's Moralia. Translated by Frank Cole Babbitt. Loeb Classical Library. 10 vols. Cambridge: Harvard University Press, 1962.

Polaski, Donald C., and Sandra Hack Polaski. "Listening to a Conversation: Divorce, the Torah, and Earliest Christianity.” Review \& Expositor 106 (Fall 2009): 591-602.

Polybius. The Histories. Loeb Classical Library. 6 vols. Translated by William Roger Paton. New York: Putnam, 1922-1927.

Pomeroy, Sarah B. Goddesses, Whores, Wives, and Slaves: Women in Classical Antiquity. New York: Schoken, 1975.

Porter, Stanley E. The Criteria for Authenticity in Historical-Jesus Research: Previous Discussion and New Proposals. Sheffield: Sheffield Academic Press, 2000.

Posphishil, Victor J. "Divorce and Remarriage in the Early Church." Irish Theological Quarterly 38 (1971): 338-347.

. Divorce and Remarriage: Towards a New Catholic Teaching. New York: Herder and Herder, 1967.

Pring, Julian Talbot, comp. The Oxford Dictionary of Modern Greek. Oxford: Clarendon, 1982.

Procksh, O. " $\lambda \dot{u} \omega . "$ Theological Dictionary of the New Testament. Edited by Gerhard Kittel and Gerhard Friedrich. Translated by Geoffrey W. Bromiley. Grand Rapids: Eerdmanns, 1964-1976. 4:328-329. 
Purdue, Leo G. "Marriage, Divorce, and Family in Second Temple Judaism." In Families in Ancient Israel, edited by Leo G. Purdue, Joseph Blenkinsopp, John J. Collins, and Carol Meyers, 104-222. Louisville, KY: Westminster John Knox, 1997.

Quesnell, Quentin. "Made Themselves Eunuchs for the Kingdom of Heaven (Matt 19:12)." Catholic Biblical Quarterly 30 (July 1968): 345.

Quispel, Gilles, trans. Ptolémée lettre a Flora. Vol. 24 of Sources chrétiennes. Paris: Du Cerf, 1966.

Rabin, Chaim, trans. The Zadokite Documents. Oxford: Clarendon, 1954.

Rahlfs, Alfred, ed. Septuaginta: Id est vetus testamentum graece iuxta LXX interpretes. Stuttgart: Württembergische Bibelanstalt, 1971.

Rawson, Beryl. "Roman Concubinage and Other de facto Marriages." In Transactions of the American Philological Association, 104, 279-305. Cleveland, OH: Case Western University Press, 1974.

Regazzi, Mark B. "The Delimitation of Pericopes: A Case Study in Matthew.” Ph.D. diss., Andrews University, 2000.

Reid, Barbara E. The Gospel according to Matthew. Collegeville, MN: Liturgical Press, 2005.

Rhoads, David, and Donald Michie. Mark as Story: An Introduction to the Narrative of the Gospel. Philadelphia: Fortress, 1982.

Richards, Larry. Marriage: A Healing Gift from God. Waco, TX: Word, 1981.

Richardson, Alan. The Miracle-Stories of the Gospels. London: SCM Press, 1956.

Riches, John Kenneth. “The Social World of Jesus.” Interpretation 50 (1996): 383-393.

Rigg, Horace Abram, Jr. "Papias on Mark.” Novum Testamentum 1 (1956): 161-183.

Riggs, Douglas Lee. "A Rhetorical-Critical Interpretation of the Divorce and Remarriage Passages in the Synoptic Gospels.” Ph.D. diss., Southwestern Baptist Theological Seminary, 1991.

Rist, John M. On the Independence of Matthew and Mark. New York: Cambridge University Press, 1978.

Roberts, Alexander, and James Donaldson, eds. The Ante-Nicene Fathers. 10 vols. Grand Rapids, MI: Eerdmans, 1951.

Robinson, James M. The Problem of History in Mark. Naperville, IL: A. R. Allenson, 1957. 
Rohde, Joachim. Rediscovering the Teaching of the Evangelists. New Testament Library. Translated by Dorothea M. Barton. London: SCM Press, 1968.

Roskam, Hendrika Nicoline. The Purpose of the Gospel of Mark in Its Historical and Social Context. Leiden: Brill, 2004.

Roth, Cecil. The History of the Jews of Italy. Philadelphia: Jewish Publication Society of America, 1946.

Rubio, Julie Hanlon. "Three-In-One-Flesh: A Christian Reappraisal of Divorce in Light of Recent Studies." Journal of the Society of Christian Ethics 23 (Spring-Summer 2003): 47-70.

Rufus, Musonius. Musonius Rufus. Translated by Amand Jagu. New York: Olms, 1979.

Safrai, Samuel, Michael Stern, David Flusser, and Willem Cornelius van Unnik. The Jewish People in the First Century. Compendia rerum indicaram ad novum testamentum. 2 vols. Assen, Netherlands: Von Gourcum, 1974-1976.

Saldarini, Anthony J. Pharisees, Scribes and Sadducees in Palestinian Society. Wilmington, DE: M. Glazier, 1988.

Saller, Richard P. "Men's Age at Marriage and Its Consequences in the Roman Family." Classical Philology 82 (1987): 179-199.

Sanders, Ed Parish. Jesus and Judaism. Philadelphia: Fortress, 1985.

. "Jesus and Sinners." Journal for the Study of the New Testament 19 (1983): 536.

. Paul and Palestinian Judaism. Philadelphia: Fortress, 1977.

Sanders, Ed Parish, and Margaret Davies. Studying the Synoptic Gospels. Philadelphia: Trinity, 1989.

Schams, Christine. Jewish Scribes in the Second-Temple Period. Sheffield: Sheffield Academic Press, 1998.

Schillebeeckx, Edward. Marriage: Human Reality and Saving Mystery. Translated by N. D. Smith. New York: Sheed and Ward, 1965.

Schmidt, Karl Ludwig. Die rahmen der geschichte Jesu. Darmstadt: Wissenchaftliche, 1919.

Schnackenburg, Rudolf. Die Ehe nach dem Neuen Testament: Theologie der ehe. Gottingen: Regensburg, 1969. . The Moral Teaching of the New Testament. Freiburg: Herder, 1965. 
Schüssler-Fiorenza, Elizabeth. In Memory of Her: A Feminist Theological Reconstruction of Christian Origins. New York: Crossroad, 1983.

Schweitzer, Albert. The Kingdom of God in Primitive Christianity. Translated by L. A. Garrard. London: Black, 1968.

Schweizer, Eduard. The Good News according to Mark. Translated by Donald H. Madvig. Richmond, VA: John Knox, 1970.

Scorgie, Glen G. The Journey Back to Eden: Restoring the Creator's Design for Women and Men. Grand Rapids, MI: Zondervan, 2005.

Scullard, Howard Hayes. A History of the Roman World 753-146 B.C. 4th ed. New York: Methuen, 1980.

Selby, G. R. Jesus, Aramaic, and Greek. Doncaster, UK: Brynmill, 1989.

Selderhuis, S. J. Marriage and Divorce in the Thought of Martin Bucer. Sixteenth Century Essays \& Studies. 48 vols. Edited by Raymond A. Mentzer. Translated by John Vriend and Lyle D. Bierma. Ann Arbor, MI: Edward Brothers, 1999.

Seneca. Seneca: Moral Essays. Translated by John W. Basore. Loeb Classical Library. 3 vols. Cambridge: Harvard University Press, 1935.

. Seneca's Tragedies. Translated by Frank Justus Miller. Loeb Classical Library. 2 vols. Cambridge: Harvard University Press, 1953.

Shaner, Donald W. A Christian View of Divorce. Leiden: Brill, 1969.

Shin, H. W. Textual Criticism and the Synoptic Problem: The Search for Valid Criteria. Dudley, MA: Peeters, 2004.

Shirah, Tharel. "The Teaching of the New Testament Concerning Marriage Dissolution and Subsequent Marriages.” Th.D. diss., New Orleans Baptist Theological Seminary, 1983.

Siculus, Diodorus. Library of History. Translated by Charles Henry Oldfather. Loeb Classical Library. Cambridge, MA: Harvard University Press. 1933-1967.

Sigal, Phillip. "Elements of Male Chauvinism in Classical Halakah.” Judaism 24 (Spring 1975): 226-244.

Skaist, Aaron Jacob "Studies in Ancient Near Eastern Marriage and Divorce Law." Ph.D. diss., University of Pennsylvania, 1963.

Smith, David L. "Divorce and Remarriage in Church History.” Didaskalia 11 (Spring 2000): 59-75. 
Sokoloff, Michael. A Dictionary of Jewish Palestinian Aramaic. Jerusalem: Bar Ilan University Press, 1990.

Sophocles, E. A. Greek Lexicon of the Roman and Byzantine Periods (from BC 146 to $A D$ 1100). 2 vols. New York: Fredrick Ungar, 1957.

Soulen, Richard N. "Marriage and Divorce: A Problem in New Testament Interpretation." Interpretation 23 (1969): 439-450.

Standaert, Benoît. Évangile selon Marc commentaire: Deuxième partie Marc 6,14 à 10,52. Études Bibliques 61. Pendé, France: J. Gabalda et $C^{\text {ie }}, 2010$.

Standahl, Kirsten. The School of St. Matthew and Its Use of the OT. Philadelphia: Fortress, 1968.

Stein, Robert H. Difficult Sayings in the Gospels: Jesus' Use of Overstatement and Hyperbole. Grand Rapids, MI: Baker Books, 1985.

. Gospels and Tradition: A Study on Redaction Criticism of the Synoptic Gospels. Grand Rapids, MI: Baker Books, 1991.

. "Is It Lawful for a Man to Divorce His Wife?" Journal of the Evangelical Theological Society 22 (June 1979): 115-121.

. Mark. Baker Exegetical Commentary of the New Testament. Edited by Robert H. Stein and Robert Yarbrough. Grand Rapids, MI: Baker Academic, 2008. . The Method and Message of Jesus Teaching. Philadelphia: Westminster, 1978.

Stern, Menahem, ed. The World History of the Jews: The Diaspora in the Hellenistic Roman World. Jerusalem: Israel Academy of Science and Humanity, 1983.

Stock, Augustine. The Method and Message of Mark. Wilmington, DE: Michael Glazier, 1989.

Stock, Klemens. Marco: Comentario Contestuale al Secondo Vangelo. 2nd ed. Rome: Edizioni ADP, 2010.

Stonehouse, Ned B. The Witness of Matthew and Mark to Christ. Philadelphia: Presbyterian Guardian, 1944.

Strabo. The Geography of Strabo. Translated by Horace Leonard Jones. Loeb Classical Library. 10 vols. New York: Putnam, 1917-1933.

Strecker, Georg. Jesus Christus in historie und theologie. Tübingen: Mohr, 1975.

Streeter, Burnett Hillman. The Four Gospels. London: MacMillan, 1937. 
Stylianopoulos, Theodore G. "The Indissolubility of Marriage in the New Testament: Principle and Practice." Greek Orthodox Theological Review 34 (Winter 1989): 335-345.

Suetonius, Gaius. Suetonius. Translated by John C. Rolfe. Loeb Classical Library. 2 vols. Cambridge: Harvard University Press, 1997-1998.

Swanson, Reuben, ed. New Testament Greek Manuscripts: Matthew to Acts. 5 vols. Sheffield: Sheffield Academic Press, 1995.

Swete, Henry Barclay. The Gospel according to St. Mark: The Greek Text with Introduction, Notes, and Indices. 3rd ed. 1913. Reprint, Grand Rapids, MI: Eerdmans, 1951.

Swidler, Leonard J. Women in Judaism. Metuchen, NJ: Scarecrow, 1976.

Synopsis of the Four Gospels. 3rd ed. Edited by Kurt Aland. New York: United Bible Societies, 1979.

Synopsis Quattuor Evangeliorum. $10^{\text {th }}$ ed. Edited by Kurt Aland. Stuttgart: Deutsche Bibelstiftung, 1978.

Tacitus, Cornelius. The Annals. Translated by John Jackson. New York: Putnam, 1931. . The Histories. Loeb Classical Library. 4 vols. Translated by Clifford H. Moore. Cambridge: Harvard University Press, 1931-1937.

Taylor, Vincent. The Gospel according to St. Mark. London: Macmillan, 1952.

Tcherikover, Avigdor. Hellenistic Civilization and the Jews. Translated by S. Applebaum. Philadelphia: Jewish Publication Society of America, 1959.

Teicher, Jacob L. “Jesus' Sayings in the Dead Sea Scrolls." Journal of Jewish Studies 5 (1954): 38.

Telford, William R. Mark. London: T \& T Clark 2003.

. The Theology of the Gospel of Mark. New York: Cambridge University Press, 1999.

Thielman, Frank. The Law and the New Testament: The Question of Continuity. New York: Crossroad, 1999.

Theissen, Gerd. Sociology of Early Palestinian Christianity. Translated by John Bowden. Philadelphia: Fortress, 1977. 
Thiessen, Gerd, and Dagmar Winter. "The Enlightenment: Critical Method as the Reconstruction of the History behind the Text." In The Quest for the Plausible Jesus: The Question of Criteria, 32-37. Louisville, KY: Westminster John Knox Press, 2002.

Thompson, W. E. “Athenian Marriage Patterns: Remarriage." California Studies in Classical Antiquity 5 (1972): 211-225.

Throntveit, Mark A. Ezra-Nehemiah. Louisville, KY: John Knox Press, 1992.

Tigay, Jeffrey H. Deuteronomy: The Traditional Hebrew Text with the New JPS

Translation. Jewish Publication Society Torah Commentary. Philadelphia: Jewish Publication Society, 1996.

Tighe, Ambrose. The Development of the Roman Constitution. New York: Appleton, 1889.

Tolbert, Mary Ann. Sowing the Gospel: Mark's World in Literary Historical Perspective. Minneapolis: Fortress, 1989.

Treggiari, Susan. "Consent to Roman Marriage: Some Aspects of Law and Reality." Échos du Monde Classique 36 (1982): 34-44. . Roman Marriage: Iusti Coniuges from the Time of Cicero to the Time of Ulpian. New York: Oxford University Press, 1991.

Treu, Ursula, ed. Clement Alexandrinus. Berlin: Akademie, 1972.

Trilling, Wolfgang. The Gospel according to St. Matthew. 2 vols. New York: Herder and Herder, 1969.

Trocmé, Étienne. The Formation of the Gospel according to Mark. Translated by Pamela Gaughan. Philadelphia: Westminster, 1975.

Turner, Cuthbert H. The Study of the New Testament. Oxford: Clarendon, 1926.

. "Western Readings in the Second Half of St. Mark's Gospel." Journal of Theological Studies 29 (1928): 5.

Tyson, Joseph B. "Jesus and Herod Antipas.” Journal of Biblical Literature 79 (1960): 230-246.

Van Cangh, J. M. “La Galilée dans l'Évangile de Marc: Un lieu théologique?” Revue Biblique 79 (1972): 59-75.

Van Tilsborg, Sjef. The Jewish Leaders in Matthew. Leiden: Brill, 1972. 
Vander Broek, Lyle Dale. "The Markan 'Sitz im Leben': A Critical Investigation into the Possibility of a Palestinian Setting for the Gospel.” Ph.D. diss., Drew University, 1983.

Vargas-Machuca, Antonio. "Divorcio e indisolubilidad del matrimonio en la sagrada escritura." Estudios Biblicos 39 (1981): 34.

Vawter, Bruce. "The Divorce Clause of Mt 5, 32 and 19, 9." Catholic Biblical Quarterly 16 (1954): 155-167.

. "Divorce in the New Testament." Catholic Biblical Quarterly 39 (1977): 528542.

Vermes, Geza. The Dead Sea Scrolls: Qumran in Perspective. Philadelphia: Fortress, 1977.

. Jesus the Jew: A Historian's Reading of the Gospels. London: Collins, 1973.

. "Sectarian Matrimonial Halahkah in the Damascus Rule." Journal of Jewish Studies 25 (1974): 197-202.

Via, Dan O. The Ethics of Mark's Gospel. Philadelphia: Fortress, 1985.

Von Allmen, Jean-Jacques. Pauline Teaching on Marriage. New York: MorehouseBarlow, 1963.

Von Rad, G. Deuteronomy: A Commentary. Translated by Dorothea Barton. London: S.C.M., 1966.

Wallace, Daniel B. Greek Grammar Beyond the Basics: An Exegetical Syntax of the New Testament. Grand Rapids, MI: Zondervan, 1996.

Walls, Andrew F. "Papias and Oral Tradition." Vigiliae Christianae 21 (1967): 137-140.

Warren, Larissa Bonfante. "The Women of Etruria." In Women in the Ancient World: The Arethusa Papers, edited by John Peradotto and J. P. Sullivan, 229-239. Albany: State University of New York Press, 1984.

Watson, Allan. "The Divorce of Carvilius Ruga." Tijdschrift voor Rechsgeschiedenis 33 (1965): 33-41.

. The Law of the Ancient Romans. Dallas, TX: Southern Methodist University Press, 1979.

. The Law of Persons in the Later Roman Republic. Oxford: Clarendon, 1967. . Rome of the XII Tables. Princeton: University Press, 1975 
Watson, Allan. The State, Law, and Religion: Ancient Rome. Athens: University of Georgia Press, 1992.

Weber, Thomas, and Rami G. Khouri. Umm qais: Gadara of the Decapolis. Amman: Al Kutba, 1989.

Weeden, Theodore J., Sr. Mark: Traditions in Conflict. Philadelphia: Fortress, 1979.

Weibling, James M. "Reconciling Matthew and Mark on Divorce." Trinity Journal 22 (2001): 219-235.

Weinfeld, Moshe. Deuteronomy and the Deuteronomic School. Oxford: Clarendon, 1972.

Wenham, Gordon J. "The Biblical View on Marriage and Divorce: OT Teaching." Third Way 23 (1977): 2-13.

. "Does the New Testament Approve Remarriage after Divorce?" Southern Baptist Journal of Theology 6 (Spring 2002): 30-45.

. "Marriage and Divorce in the Old Testament." Didaskalia 1 (November 1989): 6-17.

. "May Divorced Christians Remarry?" Churchman 95 (1981): 152-153.

. "The Restoration of Marriage Reconsidered." Journal of Jewish Studies 30 (1979): 36-40.

."The Syntax of Matt 19:9." Journal for the Study of the New Testament 28 (1986): 17-23.

Wenham, John W. Christ and the Bible. Grand Rapids, MI: Baker, 1994.

Westbrook, Robert. "The Prohibition on the Restoration of Marriage in Deut 24:1-4." In Studies in the Bible, edited by Sara Japhet, 31:77-101. Scripta Hierosolymitana 37 vols. Jerusalem: Magnes Press of Hebrew University, 1986.

Westerholm, Stephen. Jesus and Scribal Authority. Lund, Sweden: LiberLäromedel/Gleerup, 1978.

Westermarck, Edward. The History of Human Marriage. 3 vols. London: Macmilllan, 1921.

Westrup, Carl Wium. Quelques observations sur les origines du mariage para "usus" et du mariage sans "manus" dans l'ancien droit Romain. Paris: Tenin, 1926.

White, Horace, trans. Appian's Roman History. Loeb Classical Library. 4 vols. Cambridge: Harvard University Press, 1972. 
Wiebe, P. H. "The New Testament on Marriage and Divorce: Some Logical Implications." Journal of the Evangelical Theological Society 24 (June 1981): 131-138.

Wikenhauser, Alfred. New Testament Introduction. New York: Herder \& Herder, 1958.

Wilde, James Alan. "A Social Description of the Community Reflected in the Gospel of Mark.” Ph.D. diss., Drew University, 1983.

Wilson, R. A. trans. Essays in Old Testament History and Religion. Oxford: Basil Blackwell, 1966.

Winner, Lauren F. “After Divorce.” Christian Century 123 (2006): 21-22.

Wistrand, Erik Karl Hilding. The So-called Laudatio Turiae: Introduction, Text, Translation, and Commentary. Vol. 34 of Studia Graeca et Latina Gothoburgensia. Göteborg: Acta Universitatis Gothoburgensis, 1976.

Witherington, Ben, III. The Gospel of Mark: A Social-Rhetorical Commentary. Grand Rapids, MI: Eerdmans, 2001. . "Matthew 5:32 and 19:9: Exception or Exceptional?" New Testament Studies (1985): 571-576.

Wohlenberg, Gustav. Des evangelium des Markus. Leipzig: A Deickert, 1910.

Wright, Nicholas Thomas. Simply Christian: Why Christianity Makes Sense. New York: HarperCollins, 2006.

Yancey, Philip. The Jesus I Never Knew. Grand Rapids, MI: Zondervan, 1995.

Yaron, Reuven. Introduction to the Law of the Aramaic Papyri. Oxford: Clarendon, 1961.

Yonge, C. D., trans. The Works of Philo. Peabody, MA: Hendrickson, 1997.

Young, Brad H. Jesus, the Jewish Theologian. Peabody, MA: Hendrickson, 1995.

Young's Literal Translation of the Holy Scripture. Translated by Robert Young. Grand Rapids, MI: Baker, 1953.

Zangenberg, Jürgen, Harold W. Attridge, and Dale B. Martin, eds. Religion, Ethnicity, and Identity in Ancient Galilee: A Region in Transition. Tübingen: Mohr Siebeck, 2007.

Zwingli, Huldreich. "Annotationes huldrici Zwingli in evangelium matthaei." In Huldrici Zwingli Opera, edited by Mehciore Schulero and Io. Schulthessio. N.p: Turici ex Officina Schulthessiana, 1836. 
VITA

NAME Carlos Carrillo Camarena

FAMILY Wife, Pastor Elina; daughter Elina Nanette; sons Carlos, Paul, and Mark

\section{EMPLOYMENT HISTORY}

2001-Present Pastor, Southeastern California Conference

1995-2001 PhD Student-Contract Teacher, Andrews University

1989-1995 Religion Teacher, Northeast Brazil College

1979-1989 Pastor, Southeastern California Conference

\section{EDUCATION}

2012 Ph.D. In Religion, New Testament, Andrews University, Berrien Springs, MI

1983 M.Div. Andrews University, Berrien Springs, MI

1979 B.A. Theology; Minor, Education, Montemorelos University, México

\section{LANGUAGES}

Fluent in English, Spanish, and Portuguese

\section{MEMBERSHIPS}

Society of Biblical Literature, Adventist Society for Religious Studies 